BUILDING SCIENCE SERIES 15

baben bun tis

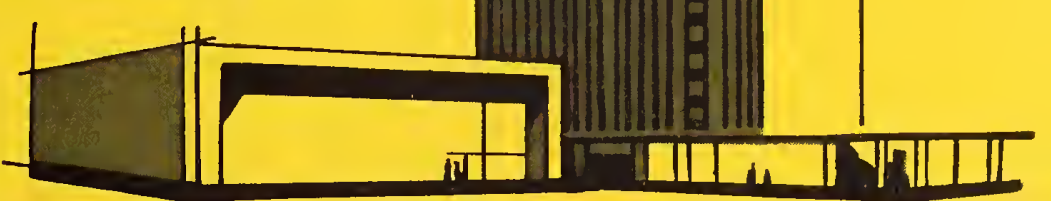

Interrelations

Between

Cement \& Concrete

Properties

PART 4 


\section{Announcing - The Building Science Series}

The "Building Science Series" disseminates technical information developed at the Bureau on building materials, components, systems, and whole structures. The series presents research results, test methods, and performance criteria related to the structural and environmental functions and the durability and safety characteristics of building elements and systems.

These publications, similar in style and content to the NBS Building Materials and Structure Reports (1938-59), are directed toward the manufacturing, design, and construction segments of the building industry, standards organizations, officials responsible for building codes, and scientists and engineers concerned with the properties of building materials.

The material for this series originates principally in the Building Research Division of the NBS Institute for Applied Technology. Published or in preparation are:

BSS1. Building Research at the National Bureau of Standards. (In preparation.)

BSS2. Interrelations Between Cement and Concrete Properties: Part 1, Materials and Techniques, Water Requirements and Trace Elements. 35 cents.

BSS3. Doors as Barriers to Fire and Smoke. 15 cents.

BSS4. Weather Resistance of Porcelain Enamels: Effect of Exposure Site and Other Variables After Seven Years. 20 cents.

BSS5. Interrelations Between Cement and Concrete Properties: Part 2, Sulfate Expansion, Heat of Hydration, and Autoclave Expansion. 35 cents.

BSS6. Some Properties of the Calcium Aluminoferrite Hydrates. 20 cents.

BSS7. Organic Coatings-Properties, Selection, and Use. $\$ 2.50$.

BSS8. Interrelations Between Cement and Concrete Properties: Part 3, Compressive Strength of Mortars. 55 cents.

BSS9. Thermal-Shock Resistance for Built-up Membranes. 20 cents.

BSS10. Field Burnout Tests of Apartment Dwelling Units. 25 cents.

BSS11. Fire Resistance of Steel Deck Floor Assemblies. 25 cents.

BSS12. Performance of Square-Edged Orifices and Orifice-Target Combinations as Air Mixers. 15 cents.

BSS13. Shrinkage and Creep in Prestressed Concrete. 15 cents.

BSS14. Experimental Determination of Eccentricity of Floor Loads Applied to a Bearing Wall. 15 cents.

Send orders with remittance to: Superintendent of Documents, U.S. Government Printing Office, Washington, D.C. 20402. Remittances from foreign countries should include an additional one-fourth of the purchase price for postage.

[See mailing list announcement on last page.] 


\title{
Interrelations Between Cement and Concrete Properties, Part 4
}

\section{Shrinkage of Neat Portland Cement Pastes and Concretes}

\author{
R. L. Blaine, H. T. Arni, and D. N. Evans
}

Building Research Division Institute for Applied Technology

National Bureau of Standards

Washington, D.C. 20234

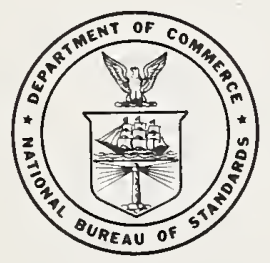

Building Science Series 15

Issued March 1969 


\section{Contents}

Section 9. Shrinkage of hardened portland cement pastes

R. L. Blaine, H. T. Arni and D. N. Evans,

Section 10. Shrinkage and Expansion of Concrete $\ldots \ldots \ldots$

R. L. Blaine and H. T. Arni

Library of Congress Catalog Card Number : 64-60095 


\title{
Section 9. Shrinkage of Hardened Portland Cement Pastes
}

\author{
R. L. Blaine, H. T. Arni, and D. N. Evans
}

\begin{abstract}
The relationship between cement properties and drying shrinkage of partially hydrated neat cement pastes of normal consistency made of a large number of portland cements of different types and composition were studied by fitting multivariable regression equations with the aid of a digital computer. The time of cracking of annular specimens restrained from shrinking by a steel core varied from 0.1 to more than 40 hours. The principal variables which appeared to have the greatest effect were the fineness and $\mathrm{K}_{2} \mathrm{O}$ and $\mathrm{C}_{4} \mathrm{AF}$ contents of the cements. The fineness and $\mathrm{K}_{2} 0$ contents of the cements appeared to have the greatest effect on the nonrestrained shrinkage of prisms at the time of cracking of the annular specimens. The shrinkage of neat cement bars after 1,6 , 27 days, and 6 months in laboratory air differed greatly with different cements. The principal variables appeared to be the $\mathrm{C}_{3} \mathrm{~A}, \mathrm{SO}_{3}$, and $\mathrm{C}_{3} \mathrm{~A} / \mathrm{SO}_{3}$ ratios. Other commonly determined variables were associated with each of the above test values. The trace elements, other than $\mathrm{Na}_{2} \mathrm{O}$ and $\mathrm{K}_{2} \mathrm{O}$, were not generally associated with the shrinkage or cracking characteristics.
\end{abstract}

Key Words: Chemical composition of portland cements; cracking of portland cements; cracking resistance of cements; portland cement; shrinkage of portland cements; trace elements.

\section{CONTENTS}

1. Introduction

2. Materials

Tests and nomenclature

4. Statistical treatment

5. Results of tests

5.1. Nonrestrained shrinkage after $24 \mathrm{hr}$ drying

5.2. Nonrestrained shrinkage after 6 days drying

5.3. Nonrestrained shrinkage after 28 days drying

5.4. Nonrestrained shrinkage after 6 months drying

5.5. Time of cracking of annular specimens restrained from shrinkage

5.6. Nonrestrained shrinkage of prisms at time of cracking of annular specimens

5.7. Ratio of nonrestrained shrinkage at time of cracking of annular specimens to the nonrestrained shrinkage at 7 days, (SB/S7) -

Page

1

2

2

4

4

4

8

9

11

14

19

21

5.8. Ratio of nonrestrained shrinkage of bars at time of cracking of the annular specimens to the nonrestrained shrinkage of the bars at 28 days, (SHBR/SH28) or (SB/S28) .

5.9. Results of duplicate determinations

5.10. Comparative test-values on other hydraulic cements

5.11. Comparison with cements from other sources

6. Discussion

6.1. Nonrestrained shrinkage versus age $\ldots \ldots \ldots 28$

6.2. Trends of variables_._._._._._._._._. 28

6.3. Shrinkage characteristics of neat cement pastes versus compressive strength of 1: 2.75 (cement to sand) mortars........

7. Summary and conclusions

8. References

\section{Introduction}

Many hundreds of articles have been published relative to the drying shrinkage of portland cements, mortars, and concretes. Many of these have been reviewed, discussed, and referenced in the various international symposia on the chemistry of cements, - in Stockholm, in 1938 [1], ${ }^{1}$ in London in 1952 [2], and in Washington in 1960 [3]. These many articles attest, to some extent, to both the importance and complexity of the phenomenon.

These reports of investigations of the many variables associated with drying shrinkage in-

\footnotetext{
${ }^{1}$ Figures in brackets refer to literature references at the conclu-
} sion of this section, p, 35 . cluded information on the effects of fineness, tri-calcium aluminate, gypsum, and the alkalies in the cements. Little or no information was presented on the effects of other differences in the composition of the cements, or of possible effects of trace elements on the drying shrinkage. The shrinkage was generally recognized to result from the drying or changes in moisture content of the colloidal material or gel formed as the hydration product of the cement.

At the time the present study of the interrelation between cement and concrete properties was initiated, a test method had been proposed [4] for determining amount of shrink- 
age of the nonrestrained bars and the time of cracking of annular specimens of partially hydrated neat cement pastes. This test method appeared, at that time, to offer a means for evaluating shrinkage and cracking characteristics of the different cements. Shrinkage tests were, however, also made on concrete specimens, as information was required on the de- gree of correlation of tests made on the neat pastes and those made on the concretes.

This section of this series of articles deals primarily with the variables associated with the shrinkage characteristics of the neat cement pastes. The studies of shrinkage of concretes made from these cements will be presented in the following section.

\section{Materials}

The portland cements used in this study have previously been described $[5,6,7]$. Briefly, they consisted of 199 commercially manufactured portland cements of the different types, and obtained from different areas of the USA, with a few obtained from other countries. These were classified primarily on the basis of their chemical composition and physical tests, and included 82 Type I, 68 Type II, 20 Type III, 3 Type IV, and 12 Type V cements. Also included were 14 air-entraining cements. The chemical analyses and other tests previously reported in previous sections of this series of articles $[6,7,8,9,10,11,12]$ indicated that the cements had a fairly broad range of compositions and properties.

\section{Tests and Nomenclature}

Neat portland cement pastes were mixed using a mechanical mixer specified for mixing hydraulic cement mortars [13]. The percentage mixing water used with $1000 \mathrm{~g}$ of cement was the same as that previously required [6] for normal consistency of each of the cement samples. The mixing time was the same as that required for hand mixing. The first $30 \mathrm{~s}$ were at the No. 1 speed and next $60 \mathrm{~s}$ at the No. 2 speed [13]. A determination was then made of the Vicat penetration. This paste was then returned to the mixing bowl and the whole mass remixed for $15 \mathrm{~s}$ before filling the molds. Two types of molds were used,- -one for $1 \times 1 \times$ 10-in (effective-gage-length) specimens for nonrestrained shrinkage ${ }^{2}$ measurements, and the second for annular specimens for determining the time of cracking of specimens restrained from shrinkage by a chromium-plated steel disc 1 in thick and 3.25 in in diameter, see figure $9-1^{3}$.

The cement paste was tamped into the lightly greased molds, troweled flush with the tops of the molds, covered with plastic, and then cured at $73 \pm 1^{\circ} \mathrm{F}$ and 95 to 100 percent relative humidity for 24 hours. The specimens were then removed from the molds and exposed to air in the laboratory at $73^{\circ} \mathrm{F}$ and $50 \pm 5$-percent relative humidity. The length of each prism was measured when removed from the mold and a line of conducting paint was placed near the outer edge on each annulax specimen.

\footnotetext{
2 The term "nonrestrained" or "free" shrinkage as used in this article indicates that no external restraint or force was used. It does not imply that the intrinsic internal restraints dependent on the size and shape of the specimens, the amount of nonhydrated cement in the paste, and the rate of evaporation of water from the specimens do not exist.

${ }^{3}$ The mold dimensions and test procedures were modified from those proposed in the RILEM specification to permit use of avail. able prism molds. The cross sectional areas and the areas of the surfaces exposed to the laboratory air were approximately the same for the bars and annular specimens.
}
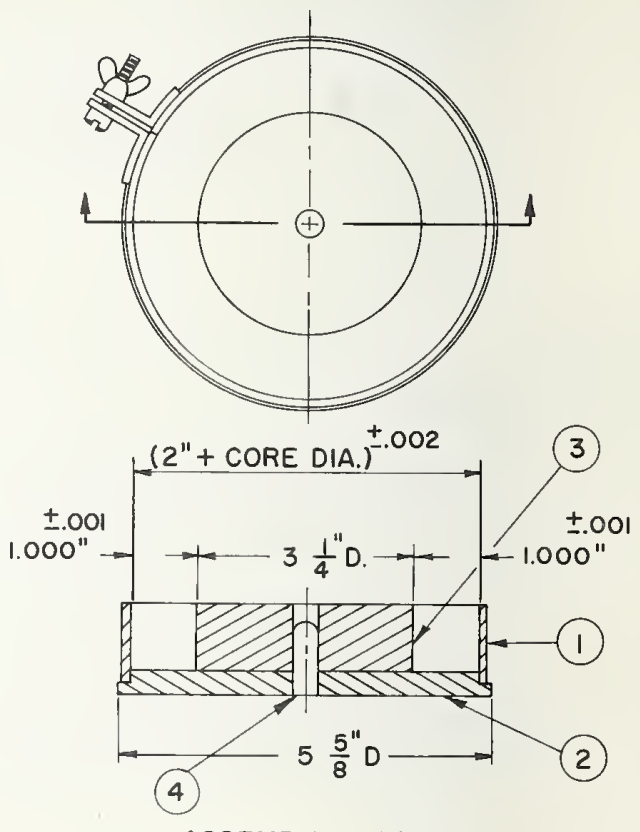

ASSEMBLY VIEW

FIGURE 9-1. Mold for use in making annular specimens.

The removable brass ring (1) and base plate (2) held the chrome plated steel dise (3) in place with the center (4) during placing and tamping of the neat cement paste in the annular space.

Up to six pairs of prisms and annular specimens were supported in a rack (see figure 9-2) and arranged so that the length changes of the prisms could be measured continuously by means of the dial gages which were graduated to $0.0001 \mathrm{in}$. The electronic detecting device (see figure 9-3) was used to turn off an electric clock when an annular specimen with a steel core broke because of drying shrinkage. 


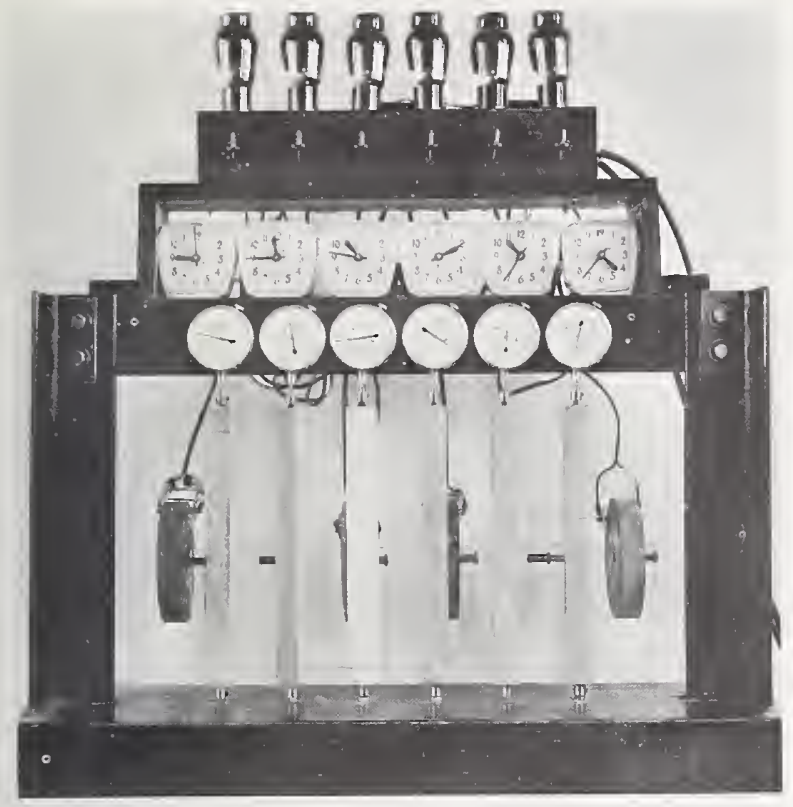

FIGURE 9-2. Rack for supporting bars and annular specimens for non-restrained and restrained shrinkage tests.
The length changes of the prisms or tars were measured at 15 and $30 \mathrm{~min}, 1,3,6$, and 24 $\mathrm{hr}$ after removal from the molds or when it was noted that one of the clocks had stopped. An automatic camera was used to photograph the equipment with the dial gages and clocks every hour after the regular work day. The length measurements of the prisms at the time of breaking of the annular specimens were interpolated from the readings or from the pictorial records. At 24 or $48 \mathrm{hr}$ after removal from moist-air storage (depending on the time of cracking of the annular specimen) the prisms were removed from the rack, measured with a standard comparator, and then placed on another rack in the laboratory at $73^{\circ} \mathrm{F}$ and 50 -percent relative humidity, and length measurements made at 7 and 28 days, 6 months, and 1 year.

The rack holding the specimens after they were first removed from the molds and moist storage was maintained in one position in the laboratory for the duration of tests on all the specimens. The rate of air-flow and humidity may have varied to some extent during the months required to make the tests. No attempt

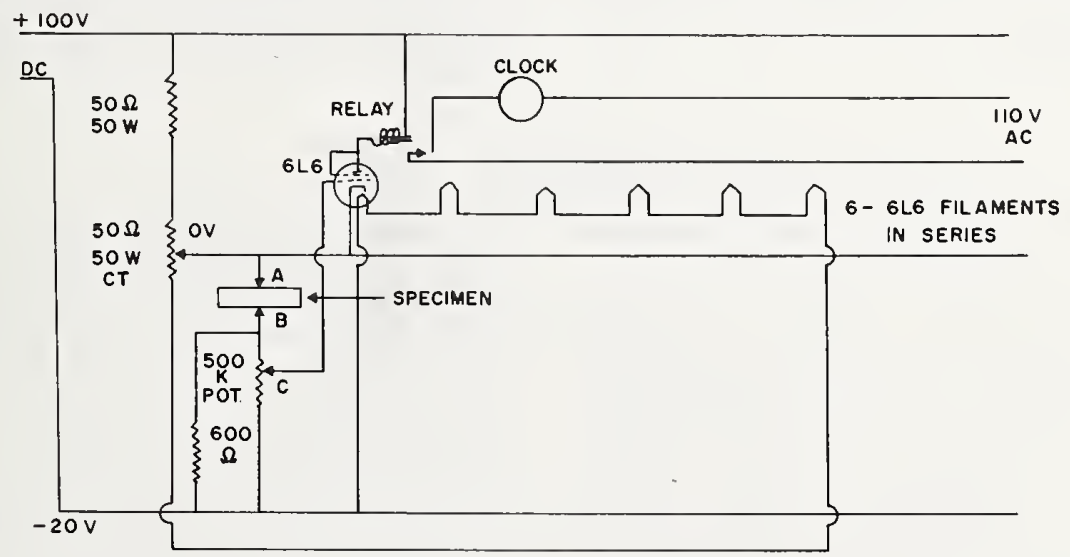

FIGURE 9-3. Diagram of electrical circuit used for stopping the electric clocks at time of cracking of the annular specimens.

With a specimen of low electrical resistance in place between terminals A \& B, there is a drop of $20 \mathrm{~V}$ across the two parallel resistors of $600 \Omega$ and $500 \mathrm{~K}$. The potentiometer (c) can then be adjusted to apply any desired grid bias from 0 to -20 Volts, thus controlling the plate current through the $6 \mathrm{~L} 6$ tube. This is set at a point so as to just keep the relay closed. Upon breaking of the sample the resistance between points $\mathrm{A} \& \mathrm{~B}$ increases. This causes point $\mathrm{B}$ to become more negative with respect to point $A$, which in turn increases the negative bias applied to the grid of the $6 \mathrm{~L} 6$, resulting in a decrease of current through the tube, opening the relay, and stopping the clock.

was made to control the $\mathrm{CO}_{2}$ content of the air surrounding the specimens. However, there is no reason to believe that it varied greatly from day to day.

With the large amount of data collected it was necessary to limit that which could be presented in this section. The notations or abbreviations used to designate the variables measured are as follows:
SH24, percentage shrinkage of prisms at 24 hr ;

SH07, percentage shrinkage of prisms at 7 days ;

SH28, percentage shrinkage of prisms at 28 days ;

SH6M, percentage shrinkage of prisms at 6 months ; 
TOBR, time in hours for annular specimen to crack;

SHBR, percentage shrinkage of the prisms at the time of cracking of the annular specimen;

$\mathrm{SB} / \mathrm{S} 7,=\mathrm{SHBR} / \mathrm{SH} 07$ (see above) ;

$\mathrm{SB} / \mathrm{S} 28,=\mathrm{SHBR} / \mathrm{SH} 28$ (see above).

Other notations and abbreviations are the same as those used in previous sections in this series of articles ${ }^{4}$.

Duplicate tests were made on different days using 20 portland cements obtained separately in order to evaluate the reproducibility of values for the nonrestrained shrinkage of the prisms and time of cracking of annular specimens.

\section{Statistical Treatment}

The statistical treatment of the shrinkage data was the same as that used in previous sections of this series of articles and it was described in detail in part 1, section 1 [5]. Briefly, these techniques included preliminary plots of the dependent versus major independent variables. After it had been determined which of the independent variables appeared significantly related to the dependent variable when used in a multivariable regression equation, the residuals of the equation were fitted by a least squares method to other single independent variables and the reduction in variance calculated. If any of the additional independent variables indicated a significant reduction in variance, they were tried in the multivariable equation and retained if the coef./s.d. ratio was greater than $1^{5}$.
As in previous sections, equations were calculated using both the potential compounds and the oxides as principal independent variables, then with commonly determined independent variables, and then with the trace elements as added independent variables. This was done both with AE + NAE cements and with NAE cements alone. The significance of reduction in the S.D. values resulting from the use of the additional variables was calculated from various pairs of equations. Equations were also calculated for the "odds" and "evens" in the array of cements.

A large number of trial equations were calculated in order to ascertain that values of all available independent variables were considered.

\section{Results of Tests}

\subsection{Nonrestrained Shrinkage After $24 \mathrm{Hr}$. Drying}

The results of preliminary plots of the nonrestrained shrinkage of the neat cement prisms at various ages versus individual independent variables are presented in figure 9-4. The lines drawn through the 12 pairs of averages to indicate the trend, and the significance of the number of points in the opposite quadrants as well as the "quadrant sum" have previously been discussed in section 1, subsections 4.1 and 5 [5]. It may be noted that for the 24-hr shrinkage (SH24), $\mathrm{SiO}_{2} \mathrm{Al}_{2} \mathrm{O}_{3}, \mathrm{Fe}_{2} \mathrm{O}_{3}, \mathrm{SO}_{3}, \mathrm{~K}_{2} \mathrm{O}$, total alkali, $\mathrm{C}_{3} \mathrm{~A}, \mathrm{C}_{2} \mathrm{~S}, \mathrm{C}_{4} \mathrm{AF}$, fineness, and air, $1: 4$ mortars) all had "quadrant-sum" absolute val-

\footnotetext{
- Included among those notations etc. are the use of $\mathrm{C}_{3} \mathrm{~A}, \mathrm{C}_{3} \mathrm{~S}$, $\mathrm{C}_{2} \mathrm{~S}$, and $\mathrm{C}_{4} \mathrm{AF}$ for the calculated potential compound composition of the cements, viz, tricalcium aluminate, tricalcium silicate, dicalcium silicate and tetracalcium aluminoferrite. Also used are Loss for loss on ignition. Insol for insoluble residue, and APF for airpermeability fineness. Also used are $\mathrm{AE}+\mathrm{NAE}$ to designate airentraining plus non-air-entraining cements and NAE for the nonair-entraining cements. The compressive strength in psi of $1: 2.75$ (cement to sand) mortars cured for 1,3, 7, 28 days, and 1 year are designated by STO1, STO3, STO7, ST28, and ST1Y respectively.

5 The statistical terms used in this section are the same as those used in previous sections. For example, S.D. refers to the estimated standard deviation calculated from the residuals of a fitted equation, or the estimated standard deviation about an average. Also, as in previous sections, s.d. refers to the estimated standard deviation of the coefficient of an independent variable used in a fitted equation; coef./s.d., the ratio of the estimated coefficient (of an independent variable used in an equation) to its estimated standard deviation; and " $\mathrm{F} "=$ Fisher's ratio of variances. As indicated in previous sections a coef./s.d. ratio greater than one was considered to be of sufficient significance to warrant further investigation. D.F. is used to designate the number of degrees of freedom.
}

ues equal to or greater than 11 , a value which may be considered significant at the 5-percent probability level. Multivariable regression equations are considered of the greatest significance in evaluating the association of the different independent variables to the dependent variable. Some of the limitations on interpretation of multivariable regression equations, as well as other statistical techniques used in this series of articles, have been discussed in section 1, subsections $4.2,4.3$, and 5. [5].

The frequency distribution of the 24-hr percentage-shrinkage values are presented in table 9-1. Each of the types of cement, as classified, ${ }^{6}$ had a considerable range of shrinkage values, and there was considerable overlapping of the values obtained with the different types.

Selected equations ${ }^{\top}$ relating the percentageshrinkage values of the $\mathrm{AE}+\mathrm{NAE}$ cements at $24 \mathrm{hr}$ to various independent variables are presented in table 9-2. Equation 1 presents the relationship for shrinkage to $W_{1}$, the percentage water required for normal consistency of

\footnotetext{
6 As previously indicated [6], the cements were classified primarily on the basis of the chemical analysis and physical tests such as airentrainment, fineness, etc.

T The equations selected were primarily those which indicated the association with dependent variables of commonly determined variables having coef./s.d. ratios greater than 1 when used in multivariable equations, and also indicated which of minor and trace elements might also have had an effect.
} 


\begin{tabular}{|c|c|c|c|c|c|c|c|c|c|c|c|c|c|c|c|c|c|c|c|}
\hline \multirow{2}{*}{$\begin{array}{r}\text { SHRINKAGE } \\
\text { TIME }\end{array}$} & \multirow{2}{*}{ NOTE } & \multicolumn{8}{|c|}{ INDEPENDENT } & \multicolumn{10}{|c|}{ VARIABLES } \\
\hline & & $\mathrm{SiO}_{2}$ & $\mathrm{Al}_{2} \mathrm{O}$ & $\mathrm{Fe}_{2} \mathrm{O}$ & $\mathrm{CaO}$ & $\mathrm{MgO}$ & $\mathrm{SO}_{3}$ & $\mathrm{Na}_{2} \mathrm{O}$ & $\mathrm{K}_{2} \mathrm{O}$ & $\begin{array}{l}\text { TOTAL } \\
\text { ALKALL }\end{array}$ & $\mathrm{C}_{3} \mathrm{~A}$ & $\mathrm{C}_{3} \mathrm{~S}$ & $\mathrm{C}_{2} \mathrm{~S}$ & $\mathrm{C}_{4} \mathrm{AF}$ & $\frac{A}{F}$ & $\frac{S}{A+F}$ & $\begin{array}{l}\text { AIR, }, \\
\text { FINE }\end{array}$ & $\begin{array}{l}\text { WAGN, } \\
\text { FINE: }\end{array}$ & $\begin{array}{l}\text { AlR } \\
\text { I.4 MOR }\end{array}$ \\
\hline \multirow{2}{*}{24 HOURS } & (I) & $\frac{10}{2}$ & & & $\frac{6}{6}$ & & $\frac{10}{2}$ & 8 & $\frac{12}{0}$ & $\frac{10}{2}$ & $\frac{10}{2}$ & $\frac{10}{2}$ & $\frac{10}{2}$ & $\frac{10}{2}$ & 8 & $\frac{6}{6}$ & $\frac{10}{2}$ & $\frac{10}{2}$ & $\frac{10}{2}$ \\
\hline & $\begin{array}{l}\text { (3) } \\
\text { (4) }\end{array}$ & $\begin{array}{c}N L \\
-15\end{array}$ & $\begin{array}{r}\mathrm{L} ? \\
+11\end{array}$ & $\begin{array}{r}N L \\
-12 \\
\end{array}$ & $\begin{array}{l}\text { NO } \\
-2\end{array}$ & $\begin{array}{l}L ? \\
+6\end{array}$ & $\begin{array}{r}N L \\
+18\end{array}$ & $\begin{array}{l}\text { L? } \\
+3\end{array}$ & $\begin{array}{r}N L \\
+24 \\
\end{array}$ & $\begin{array}{r}\text { NL } \\
+11\end{array}$ & $\begin{array}{r}N L \\
+14\end{array}$ & $\begin{array}{l}\text { L? } \\
+9\end{array}$ & $\begin{array}{r}N L \\
-15\end{array}$ & $\begin{array}{c}N L \\
-16\end{array}$ & $\begin{array}{r}N L \\
+13 \\
+13\end{array}$ & $\begin{array}{l}\text { NO } \\
-6\end{array}$ & $\begin{array}{r}L ? \\
+13\end{array}$ & $\begin{array}{r}\text { L? } \\
+11\end{array}$ & $\begin{array}{r}L ? \\
+17 \\
\end{array}$ \\
\hline \multirow{2}{*}{6 DAYS } & (1) & $\frac{10}{2}$ & $\frac{12}{0}$ & $\frac{10}{2}$ & $\frac{10}{2}$ & $\frac{10}{2}$ & $\frac{10}{2}$ & & & & & $\frac{6}{6}$ & 10 & 10 & & $\frac{8}{9}$ & 10 & $\frac{8}{4}$ & $\frac{10}{2}$ \\
\hline & $\begin{array}{l}(3) \\
(4)\end{array}$ & $\begin{array}{r}N L \\
-14\end{array}$ & $\begin{array}{c}L \\
+24\end{array}$ & $\begin{array}{l}\mathrm{L} ? \\
-\dot{8}\end{array}$ & $\begin{array}{c}N L \\
-10\end{array}$ & $\begin{array}{r}\mathrm{L} ? \\
+8\end{array}$ & $\begin{array}{l}N L \\
+16\end{array}$ & $\begin{array}{l}L ? \\
+10\end{array}$ & $\begin{array}{r}N L \\
+24\end{array}$ & $\begin{array}{r}N L \\
+16\end{array}$ & $\begin{array}{l}N L \\
+14\end{array}$ & $\begin{array}{l}\text { NO } \\
+1\end{array}$ & $\begin{array}{l}\text { L? } \\
27\end{array}$ & $\begin{array}{r}\text { L? } \\
-10\end{array}$ & $\begin{array}{l}L ? \\
+9\end{array}$ & $\begin{array}{l}L ? \\
-5\end{array}$ & $\begin{array}{l}\text { L? } \\
+8\end{array}$ & $\begin{array}{l}\text { L? } \\
-1\end{array}$ & $\begin{array}{r}L ? \\
+17\end{array}$ \\
\hline \multirow{2}{*}{27 DAYS } & (I) & $\frac{10}{2}$ & $\frac{10}{2}$ & $\frac{8}{4}$ & $\frac{8}{4}$ & & $\frac{10}{2}$ & & $\frac{12}{0}$ & $\frac{10}{2}$ & $\frac{10}{2}$ & $\frac{6}{6}$ & 12 & $\underline{9}$ & & $\frac{10}{2}$ & $\frac{6}{6}$ & $\frac{8}{4}$ & \\
\hline & $\begin{array}{l}\text { (3) } \\
\text { (4) }\end{array}$ & $\begin{array}{l}\mathrm{NL} \\
-15 \\
\end{array}$ & $\begin{array}{r}\text { L? } \\
+12 \\
\end{array}$ & $\begin{array}{l}\mathrm{L} ? \\
-7\end{array}$ & $\begin{array}{l}\mathrm{L} ? \\
-8\end{array}$ & $\begin{array}{l}\text { L? } \\
+6\end{array}$ & $\begin{array}{r}L ? \\
+15 \\
\end{array}$ & $\begin{array}{l}\text { L? } \\
+9\end{array}$ & $\begin{array}{r}N L \\
+24 \\
\end{array}$ & $\begin{array}{r}N L \\
+17\end{array}$ & $\begin{array}{r}\mathrm{NL} \\
+14\end{array}$ & $\begin{array}{l}\text { No } \\
+4\end{array}$ & $\begin{array}{l}N L \\
-24\end{array}$ & $\begin{array}{l}L ? \\
-13\end{array}$ & $\begin{array}{r}L ? \\
+18\end{array}$ & $\begin{array}{r}\text { L? } \\
-10\end{array}$ & $\begin{array}{l}\text { NO } \\
+3\end{array}$ & $\begin{array}{c}\text { No } \\
0\end{array}$ & $\begin{array}{r}4 ? \\
+13 \\
\end{array}$ \\
\hline \multirow{2}{*}{6 MONTHS } & (1) & $\frac{12}{0}$ & $\frac{10}{2}$ & $\frac{8}{4}$ & $\frac{6}{6}$ & $\underline{8}$ & & & $\frac{10}{2}$ & $\frac{10}{2}$ & 10 & $\frac{8}{4}$ & $\frac{12}{0}$ & 8 & & $\frac{8}{4}$ & $\frac{6}{6}$ & $\frac{8}{4}$ & $\frac{10}{2}$ \\
\hline & $\begin{array}{l}(3) \\
(4)\end{array}$ & $\begin{array}{l}\text { NO } \\
-24\end{array}$ & $\begin{array}{l}\text { L? } \\
+7\end{array}$ & $\begin{array}{r}\text { L? } \\
-10\end{array}$ & $\begin{array}{l}\text { NO } \\
-7\end{array}$ & $\begin{array}{r}L ? \\
+12\end{array}$ & $\begin{array}{r}L ? \\
+12\end{array}$ & $\begin{array}{l}\text { L? } \\
+7\end{array}$ & $\begin{array}{r}\mathrm{L} \\
+20\end{array}$ & $\begin{array}{r}L \\
+17\end{array}$ & $\begin{array}{l}\text { L? } \\
+9\end{array}$ & $\begin{array}{l}\text { NO } \\
-3\end{array}$ & $\begin{array}{l}L ? \\
-24\end{array}$ & $\begin{array}{l}\text { L? } \\
-6\end{array}$ & $\begin{array}{r}L ? \\
+14\end{array}$ & $\begin{array}{l}L ? \\
-9\end{array}$ & $\begin{array}{l}\text { NO } \\
+2\end{array}$ & $\begin{array}{l}\text { No } \\
-2\end{array}$ & $\begin{array}{r}L ? \\
+12\end{array}$ \\
\hline
\end{tabular}

FIGURE 9-4. Results of plotting on the "Y" axis the percentage shrinkage in laboratory air at 24 hours, 6 days, 27 days, and 6 months of neat portland cement pastes of normal consistency cured for 24 hours in moist air versus various independent variables on the " $\mathrm{X}$ " axis.

* Note (1) Ratio of number of plotted points in pairs of diametrically opposite quadrants.

Note (2) General trend of lines drawn through plotted points.

Note (3) Apparent nature of relationship. $L=$ linear; $N L=$ nonlinear; $N O=$ no apparent relationship: and $L$ ? $=$ nature of relationship not determinable.

(Note (4) Quadrant sum in corner test (see reference 5).

TABLE 9-1. Frequency distribution of cements with respect to percentage shrinkage of neat cement pastes of normal consistency after 24 $\mathrm{hr}$ drying in laboratory air following $24 \mathrm{hr}$ moist-air curing (SH24)

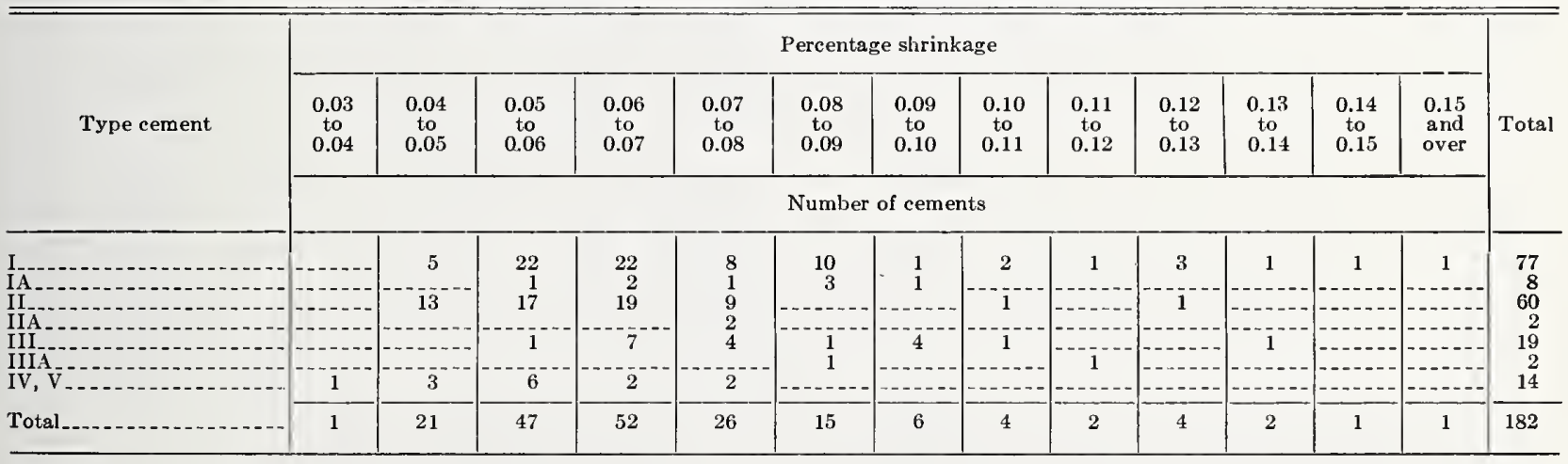

the neat pastes. The estimated S.D. value obtained in eq 1 was lower than the estimated S.D. of the cements about their average (note 1 of table 9-2). By reference to table $9-34^{8}$ it may be noted that the relationship was significant at the 1-percent probability level.

Equation 2 of table $9-2$ presents the relationships for some commonly determined variables plus the $\mathrm{C}_{3} \mathrm{~A} / \mathrm{SO}_{3}$ ratio. The use of $\mathrm{C}_{3} \mathrm{~A}, \mathrm{SO}_{3}$, and $\mathrm{C}_{3} \mathrm{~A} / \mathrm{SO}_{3}$ as independent variables was found in preliminary trial equations to result

\footnotetext{
${ }^{8} \mathrm{~A}$ tabulation of the reduction in variance or " $F$ " values for all equations compared is presented in table 9-34, page 27 . Presented also are the critical values for " $F$ " which, if equalled or exceeded, indicate significance at the 1-percent and 5-percent levels for the number of degrees of freedom (D.F.) involved in each comparison.
}

in lower S.D. values than when the $\mathrm{C}_{3} \mathrm{~A} / \mathrm{SO}_{3}$ ratio was not used. The variables $\mathrm{APF}, \mathrm{Ba}, \mathrm{P}$, $\mathrm{Zn}$, and $\mathrm{Cr}$ had coef./s.d. ratios greater than 1 when included with the variables in eq 2 (eq 3 ), and the reduction in variance was significant at the 1-percent probability level (table 9-34). Of these added variables, however, only APF and $\mathrm{Cr}$ had coef./s.d. ratios greater than 2.

Equations $3 \mathrm{~A}$ and $3 \mathrm{~B}$, calculated with the "odds" and "evens" in the array of cements, had coef./s.d. ratios less than one for the "odds" or "evens" or both, for $\mathrm{C}_{3} \mathrm{~A}, \mathrm{APF}, \mathrm{Ba}, \mathrm{P}$, and $\mathrm{Zn}$. As indicated in previous sections, this may occur when (1) the coef./s.d. ratio is not significant in the equation for all the values, or 


\begin{tabular}{|c|c|c|c|c|c|c|c|}
\hline Equation & Note & & Const. & $\mathrm{C}_{3} \mathrm{~A}$ & $\mathrm{C}_{4} \mathrm{AF}$ & $\mathrm{Al}_{2} \mathrm{O}_{3}$ & $\mathrm{Fe}_{2} \mathrm{O}_{3}$ \\
\hline $1 \ldots$ & (1) & $\begin{array}{l}\text { SH24 } \\
\text { s.d. }\end{array}$ & $\begin{array}{l}=-0.01241 \\
=(0.01734)\end{array}$ & $\mid-\ldots$ & & & \\
\hline 2 & (1) & $\begin{array}{l}\text { SH24 } \\
\text { s.d. }\end{array}$ & $\begin{array}{l}=-0.00317 \\
=(0.01558)\end{array}$ & $\begin{array}{c}-0.00514 \\
(0.00173)\end{array}$ & $\begin{array}{c}-0.001457 \\
(0.000465)\end{array}$ & 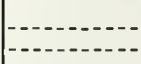 & $\mid-1-1-1-1$ \\
\hline $3 \ldots$ & (1) & $\begin{array}{l}\text { SH24 } \\
\text { s.d. }\end{array}$ & $\begin{array}{l}=-0.01903 \\
=(0.01579)\end{array}$ & $\begin{array}{r}-0.00464 \\
(0.00171)\end{array}$ & $\begin{array}{c}-0.001307 \\
(0.000455)\end{array}$ & $-1-1$ & $\mid-\cdots$ \\
\hline 3A.- & (2) & $\begin{array}{l}\text { SH24 (odd) } \\
\text { s.d. }\end{array}$ & $\begin{array}{l}=-0.01123 \\
=(0.02211)\end{array}$ & $\begin{array}{c}-0.00608 \\
(0.00228)\end{array}$ & $\begin{array}{c}-0.001979 \\
(0.000735)\end{array}$ & - & -- \\
\hline 3B... & $\left({ }^{3}\right)$ & $\begin{array}{l}\text { SH24 (even) } \\
\text { s.d. }\end{array}$ & $\begin{array}{l}=-0.02046 \\
=(0.02466)\end{array}$ & $\begin{array}{r}*-0.00273 \\
(0.00290)\end{array}$ & $\begin{array}{c}-0.000837 \\
(0.000594)\end{array}$ & $\mid$ & 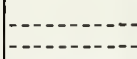 \\
\hline $4 \ldots$ & (1) & $\begin{array}{l}\text { SH24 } \\
\text { s.d. }\end{array}$ & $\begin{array}{l}=-0.02801 \\
=(0.01859)\end{array}$ & & & $\begin{array}{r}-0.01094 \\
(0.00375)\end{array}$ & $\begin{array}{r}-0.00431 \\
(0.00114)\end{array}$ \\
\hline $5 \ldots$ & (1) & $\begin{array}{l}\text { SH24 } \\
\text { s.d. }\end{array}$ & $\begin{array}{l}=-0.03981 \\
=(0.01855)\end{array}$ & & & $\begin{array}{r}-0.01217 \\
(0.00371)\end{array}$ & $\begin{array}{r}-0.00450 \\
(0.00112)\end{array}$ \\
\hline $5 A_{\ldots} \ldots$ & (2) & $\begin{array}{l}\text { SH24 (odd) } \\
\text { s.d. }\end{array}$ & $\begin{array}{l}=-0.02792 \\
=(0.02441)\end{array}$ & & & $\begin{array}{r}-0.01425 \\
(0.00465)\end{array}$ & $\begin{array}{r}-0.00559 \\
(0.00183)\end{array}$ \\
\hline 5B.- & $\left({ }^{3}\right)$ & $\begin{array}{l}\text { SH24 (even) } \\
\text { s.d. }\end{array}$ & $\begin{array}{l}=-0.05720 \\
=(0.03540)\end{array}$ & -- & - - - - & $\begin{array}{c}-0.01215 \\
(0.00761)\end{array}$ & $\begin{array}{c}-0.00403 \\
(0.00147)\end{array}$ \\
\hline
\end{tabular}

1163 cements; Avg $=0.0643$; S.D. $=0.01427 . \quad 282$ cements. $\quad 381$ cements. $\quad *$ Cocf./s.d. ratio less than 1.

TABLE 9-3. Coefficients for equations relating the percentage shrinkage at $24 \mathrm{hr}$ (after the cements, to various inde

\begin{tabular}{|c|c|c|c|c|c|c|c|c|}
\hline Equation & Note & & Const. & $\mathrm{C}_{3} \mathrm{~A}$ & $\mathrm{C}_{4} \mathrm{AF}$ & $\mathrm{Al}_{2} \mathrm{O}_{3}$ & $\mathrm{Fe}_{2} \mathrm{O}_{3}$ & $\mathrm{Na}_{2} \mathrm{O}$ \\
\hline 1. & (1) & $\begin{array}{l}\text { SH24 } \\
\text { s.d. }\end{array}$ & $\begin{array}{l}=-0.00196 \\
=(0.01738)\end{array}$ & & & & & \\
\hline $2 \ldots$ & (1) & $\begin{array}{l}\text { SH24 } \\
\text { s.d. }\end{array}$ & $\begin{array}{l}=-0.00182 \\
=(0.01557)\end{array}$ & $\begin{array}{c}-0.005779 \\
(0.001744)\end{array}$ & $\begin{array}{c}-0.001531 \\
(0.000466)\end{array}$ & & & $\begin{array}{r}+0.00733 \\
(0.00546)\end{array}$ \\
\hline 3 & (1) & $\begin{array}{l}\text { SH24 } \\
\text { s.d. }\end{array}$ & $\begin{array}{l}=-0.01970 \\
=(0.01581)\end{array}$ & $\begin{array}{c}-0.005532 \\
(0.001715)\end{array}$ & $\begin{array}{c}-0.001367 \\
(0.000451)\end{array}$ & -- & {$[-1$.} & $\begin{array}{r}+0.01004 \\
(0.00531)\end{array}$ \\
\hline $3 A_{\ldots}$ & (2) & $\begin{array}{l}\text { SH24 (odd) } \\
\text { s.d. }\end{array}$ & $\begin{array}{l}=-0.01592 \\
=(0.02145)\end{array}$ & $\begin{array}{c}-0.005957 \\
(0.002247)\end{array}$ & $\begin{array}{r}-0.001455 \\
(0.000643)\end{array}$ & $-\cdots$ & - & 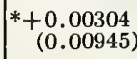 \\
\hline 3B.-. & $\left({ }^{3}\right)$ & $\begin{array}{l}\text { SH24 (even) } \\
\text { s.d. }\end{array}$ & $\begin{array}{l}=-0.01472 \\
=(0.02538)\end{array}$ & $\begin{array}{r}-0.004410 \\
(0.002904)\end{array}$ & $\begin{array}{c}-0.001007 \\
(0.000706)\end{array}$ & -- & & $\begin{array}{r}+0.00982 \\
(0.00633)\end{array}$ \\
\hline $4 \ldots$ & (1) & $\begin{array}{l}\text { SH24 } \\
\text { s.d. }\end{array}$ & $\begin{array}{l}=-0.01726 \\
=(0.01874)\end{array}$ & & & $\begin{array}{c}-0.01292 \\
(0.00370)\end{array}$ & $\begin{array}{c}-0.00455 \\
(0.00116)\end{array}$ & $\begin{array}{r}+0.00593 \\
(0.00534)\end{array}$ \\
\hline 5 & (1) & $\begin{array}{l}\text { SH24 } \\
\text { s.d. }\end{array}$ & $\begin{array}{l}=-0.03589 \\
=(0.01856)\end{array}$ & & & $\begin{array}{c}-0.01328 \\
(0.00367)\end{array}$ & $\begin{array}{c}-0.00461 \\
(0.00111)\end{array}$ & $\begin{array}{r}+0.00874 \\
(0.00516)\end{array}$ \\
\hline $5 A_{-\ldots}$ & (2) & $\begin{array}{l}\text { SH24 (odd) } \\
\text { s.d. }\end{array}$ & $\begin{array}{l}=-0.02438 \\
=(0.02426)\end{array}$ & & & $\begin{array}{c}-0.01290 \\
(0.00475)\end{array}$ & $\begin{array}{r}-0.00431 \\
(0.00161)\end{array}$ & $\begin{array}{r}*+0.00112 \\
(0.00938)\end{array}$ \\
\hline 5B.- & (s) & $\begin{array}{l}\text { SH24 (even) } \\
\text { s.d. }\end{array}$ & $\begin{array}{l}=-0.06950 \\
=(0.03376)\end{array}$ & & & $\begin{array}{c}-0.01852 \\
(0.00683)\end{array}$ & $\begin{array}{c}-0.00429 \\
(0.00167)\end{array}$ & $\begin{array}{c}+0.00907 \\
(0.00597)\end{array}$ \\
\hline
\end{tabular}

1151 cements; Avg $=0.06328$; S.D. $=0.01366 . \quad 276$ cements. $\quad{ }_{3}^{3} 75$ cements. $\quad$ * Coef./s.d. ratio less than 1.

(2) when a preponderance of the cements with very high or very low values for an independent variable happens to fall within one of the groups. $\mathrm{Zn}$ and $\mathrm{P}$ are particularly vulnerable to the second of the above contingencies because of the comparatively small number of cements for which nonzero values for these two elements were reported.

Equations 4 and 5 of table 9-2 were calculated using the oxides instead of the calculated potential compounds. The use of the trace elements in eq 5 in addition to the cornmonly determined variables in eq 4 resulted in a reduction in variance significant at the 5-percent probability level (see table 9-34). Again, only $\mathrm{APF}$ and $\mathrm{Cr}$. had coef./s.d. ratios greater than 2. In eqs $5 \mathrm{~A}$ and $5 \mathrm{~B}$ which were caiculated for the "odds" and "evens", APF, Ba, Zn, and P had coef./s.d. ratios less than 1 in one or the other of the equations.

A comparable series of equations is presented in table 9-3 for NAE cements. The coefficients of the independent variables are in reasonable agreement with those in table 9-2. $\mathrm{Rb}$ had a coef./s.d. greater than 1 in eq 5, and in the equations for the "odds" and "evens", (eqs 3A, $3 \mathrm{~B}, 5 \mathrm{~A}$, and $5 \mathrm{~B}) \mathrm{Na}_{2} \mathrm{O}, \mathrm{Ba}$, and $\mathrm{P}$ had coef./s.d. ratios less than 1 in one or the other of the smaller groups. The sign of the coefficient for $\mathrm{Zn}$ was positive in eqs $3 \mathrm{~A}$ and $5 \mathrm{~A}$ and negative in eqs $3,3 \mathrm{~B}, 5$ and $5 \mathrm{~B}$. In none of these instances were the coefficients highly significant.

Using the independent variables and their coefficients from eq 3 of table 9-3, and the 
initial $24 \mathrm{hr}$ moist-air storage) of neat-cement bars of normal consistency made of $A E+$ dependent variables (SH24)

\begin{tabular}{|c|c|c|c|c|c|c|c|c|c|c|c|}
\hline $\mathrm{Na}_{2} \mathrm{O}$ & $\mathrm{K}_{2} \mathrm{O}$ & $\mathrm{SO}_{3}$ & $\mathrm{C}_{3} \mathrm{~A} / \mathrm{SO}_{3}$ & $\mathrm{Al}_{2} \mathrm{O}_{3} / \mathrm{SO}_{3}$ & APF & $\mathrm{Ba}$ & $P$ & $\mathrm{zn}$ & $\mathrm{Cr}$ & $W_{1}$ & S.D. \\
\hline & & & & & & & & & & 0 & 0.01353 \\
\hline $\begin{array}{c}+0.00978 \\
(0.00546)\end{array}$ & $\begin{array}{c}+0.01729 \\
(0.00428)\end{array}$ & $\begin{array}{r}+0.03889 \\
(0.00760)\end{array}$ & $\begin{array}{c}+0.00925 \\
(0.00310)\end{array}$ & & & & & & & & 0.01087 \\
\hline $\begin{array}{r}+0.01220 \\
(0.00533)\end{array}$ & $\begin{array}{c}+0.02006 \\
(0.00448)\end{array}$ & $+\begin{array}{r}+0.03665 \\
(0.00799)\end{array}$ & $\begin{array}{r}+0.00876 \\
(0.00304)\end{array}$ & & $\begin{array}{r}+0.0000047 \\
(0.0000020)\end{array}$ & $\begin{array}{r}+0.04551 \\
(0.03263)\end{array}$ & $\begin{array}{r}+0.01079 \\
(0.00815)\end{array}$ & $\begin{array}{c}-0.0346 \\
(0.0306)\end{array}$ & $\begin{array}{r}+0.4462 \\
(0.2059)\end{array}$ & & 0.01049 \\
\hline $\begin{array}{r}+0.01130 \\
(0.00908)\end{array}$ & $+\underset{(0.00696)}{+0.03013}$ & $\begin{array}{r}+0.03574 \\
(0.01083)\end{array}$ & $+\underset{(0.00407)}{0.01037}$ & & $*+\underset{(0.0000033)}{+0.0000030}$ & $\begin{array}{r}+0.05713 \\
(0.04112)\end{array}$ & $\begin{array}{r}+0.02026 \\
(0.01138)\end{array}$ & $\stackrel{*-0.0027}{(0.0451)}$ & $\underset{(0.3129)}{+0.5257}$ & & 0.01117 \\
\hline $\begin{array}{c}+0.01019 \\
(0.00645)\end{array}$ & $+\underset{(0.00599)}{+0.01141}$ & $+\underset{(0.01348)}{+0.03272}$ & $+\underset{(0.00515)}{0.00622}$ & & $+\underset{(0.0000026)}{+0.0000047}$ & $\begin{array}{r}*-0.06883 \\
(0.09156)\end{array}$ & $\stackrel{*-0.00861}{(0.01204)}$ & $\begin{array}{r}*-0.0435 \\
(0.0445)\end{array}$ & $\begin{array}{l}+0.4258 \\
(0.2787)\end{array}$ & & $\begin{array}{r}0.00959 \\
-\end{array}$ \\
\hline$+\underset{(0.00524)}{0.00950}$ & $+\underset{(0.00440)}{0.01917}$ & $+\underset{(0.01014)}{0.04310}$ & & $+\underset{(0.00656)}{0.02078}$ & $\begin{array}{r}+0.0000035 \\
(0.0000020)\end{array}$ & & & & & & 0.01064 \\
\hline$+\underset{(0.00519)}{0.01165}$ & $\begin{array}{r}+0.01963 \\
(0.00442)\end{array}$ & $\begin{array}{c}+0.04603 \\
(0.00993)\end{array}$ & & $\begin{array}{r}+0.02288 \\
(0.00643)\end{array}$ & $\stackrel{+}{+0.0000042}$ & $+\underset{(0.03228)}{0.05175}$ & $+\underset{(0.00806)}{0.01122}$ & $\begin{array}{c}-0.0390 \\
(0.0302)\end{array}$ & $\begin{array}{r}+0.4531 \\
(0.2033)\end{array}$ & & 0.01036 \\
\hline $\begin{array}{c}+0.01084 \\
(0.00880)\end{array}$ & $+\underset{(0.00686)}{0.02922}$ & $+\underset{(0.01243)}{+0.04520}$ & & $\begin{array}{r}+0.02389 \\
(0.00801)\end{array}$ & $*+\underset{(0.0000033)}{+0.0000030}$ & $+\underset{(0.04071)}{+0.06262}$ & $\begin{array}{r}+0.02134 \\
(0.01125)\end{array}$ & $\stackrel{*-0.0101}{(0.0444)}$ & $\begin{array}{r}+0.5561 \\
\quad(0.3079)\end{array}$ & & 0.01101 \\
\hline $\begin{array}{r}+0.00930 \\
(0.00630)\end{array}$ & $\begin{array}{r}+0.01143 \\
(0.00590)\end{array}$ & $\begin{array}{r}+0.05558 \\
(0.02083)\end{array}$ & & $\begin{array}{r}+0.02517 \\
(0.01340)\end{array}$ & $\begin{array}{r}+0.0000036 \\
(0.0000027)\end{array}$ & $\begin{array}{r}*-0.07342 \\
(0.08952)\end{array}$ & $\begin{array}{r}*-0.00845 \\
(0.01185)\end{array}$ & $\begin{array}{r}-0.0552 \\
(0.0447)\end{array}$ & $+\underset{(0.2745)}{0.4378}$ & & 0.00945 \\
\hline
\end{tabular}

initial $24 \mathrm{hr}$ moist-air storage) of neat-cement bars of normal consistency made of NAE pendent variables (SH24)

\begin{tabular}{|c|c|c|c|c|c|c|c|c|c|c|c|}
\hline $\mathrm{K}_{2} \mathrm{O}$ & $\mathrm{SO}_{3}$ & $\mathrm{C}_{3} \mathrm{~A} / \mathrm{SO}_{3}$ & $\mathrm{Al}_{2} \mathrm{O}_{3} / \mathrm{SO}_{3}$ & APF & $\mathrm{Ba}$ & $\mathrm{P}$ & $Z_{1 \mathbf{r}}$ & $\mathrm{Cr}$ & $\mathrm{Rb}$ & $W_{1}$ & S.D \\
\hline & & & & & & & & & & $\begin{array}{r}+0.00264 \\
(0.00070)\end{array}$ & 0.01310 \\
\hline $\begin{array}{r}+0.01730 \\
(0.00436)\end{array}$ & $\begin{array}{c}+0.03907 \\
(0.00764)\end{array}$ & $\begin{array}{r}+0.01020 \\
(0.00310)\end{array}$ & & & & & & & & & 0.01064 \\
\hline $\begin{array}{r}+0.02004 \\
(0.00452)\end{array}$ & $\begin{array}{r}+0.03506 \\
(0.00791)\end{array}$ & $\begin{array}{c}+0.01012 \\
(0.00302)\end{array}$ & & $\begin{array}{c}+0.0000046 \\
(0.0000020)\end{array}$ & $\begin{array}{r}+0.05233 \\
(0.03194)\end{array}$ & $\begin{array}{c}+0.01302 \\
(0.00803)\end{array}$ & $\begin{array}{c}-0.03234 \\
(0.02979)\end{array}$ & $\begin{array}{c}+0.4422 \\
(0.2074)\end{array}$ & & & $\begin{array}{r}0.01020 \\
-\end{array}$ \\
\hline $\begin{array}{r}+0.02536 \\
(0.00683)\end{array}$ & $+\underset{(0.01024)}{0.03388}$ & $\begin{array}{r}+0.01031 \\
(0.00396)\end{array}$ & & $\begin{array}{r}+0.0000045 \\
(0.0000032)\end{array}$ & $\begin{array}{r}+0.06645 \\
(0.03715)\end{array}$ & $\begin{array}{c}+0.02752 \\
(0.01119)\end{array}$ & $\begin{array}{r}+0.06508 \\
(0.06129)\end{array}$ & $\begin{array}{r}+0.5193 \\
(0.2870)\end{array}$ & & & 0.01058 \\
\hline $\begin{array}{r}+0.01482 \\
(0.00605)\end{array}$ & $+\underset{(0.01394)}{0.03301}$ & $\begin{array}{r}+0.00381 \\
(0.00506)\end{array}$ & & $\begin{array}{c}+0.0000041 \\
(0.0000028)\end{array}$ & $\begin{array}{r}*-0.08642 \\
(0.08693)\end{array}$ & $\begin{array}{r}*-0.00841 \\
(0.01192)\end{array}$ & $\begin{array}{r}-0.05719 \\
(0.03401)\end{array}$ & $\begin{array}{r}+0.3252 \\
(0.3087)\end{array}$ & & & 0.00960 \\
\hline $\begin{array}{r}+0.01655 \\
(0.00431)\end{array}$ & $\begin{array}{c}+0.04762 \\
(0.00955)\end{array}$ & & $+\underset{(0.00649)}{0.02272}$ & & & - & & & & & 0.01062 \\
\hline $\begin{array}{r}+0.01604 \\
(0.00486)\end{array}$ & $+\underset{(0.00979)}{0.04577}$ & & $\begin{array}{r}+0.02400 \\
(0.00632)\end{array}$ & $\begin{array}{c}+0.0000044 \\
(0.0000020)\end{array}$ & $\begin{array}{r}+0.06093 \\
(0.03154)\end{array}$ & $+\begin{array}{c}+0.01148 \\
(0.00801)\end{array}$ & $\begin{array}{c}-0.03266 \\
(0.02947)\end{array}$ & $\begin{array}{r}+0.3713 \\
(0.2099)\end{array}$ & $\begin{array}{r}+0.8259 \\
(0.5065)\end{array}$ & & 0.01004 \\
\hline $\begin{array}{r}+0.02377 \\
(0.00751)\end{array}$ & $\begin{array}{r}+0.04012 \\
(0.01232)\end{array}$ & & $\begin{array}{r}+0.02158 \\
(0.00807)\end{array}$ & $\begin{array}{r}+0.0000045 \\
(0.0000033)\end{array}$ & $\begin{array}{r}+0.07151 \\
(0.03736)\end{array}$ & $\begin{array}{r}+0.02648 \\
(0.01171)\end{array}$ & $\begin{array}{r}+0.06876 \\
(0.06146)\end{array}$ & $\begin{array}{r}+0.4604 \\
(0.3082)\end{array}$ & $\begin{array}{r}*+0.4243 \\
(0.8129)\end{array}$ & & 0.01060 \\
\hline $\begin{array}{c}+0.00966 \\
(0.00619)\end{array}$ & $\begin{array}{r}+0.06589 \\
(0.01928)\end{array}$ & & $\begin{array}{r}+0.03545 \\
(0.01195)\end{array}$ & $\begin{array}{r}+0.0000030 \\
(0.0000027)\end{array}$ & $\begin{array}{r}*-0.07405 \\
(0.08275)\end{array}$ & $\begin{array}{r}*-0.00734 \\
(0.01136)\end{array}$ & $\begin{array}{c}-0.06432 \\
(0.03289)\end{array}$ & $\begin{array}{r}+0.3388 \\
(0.2960)\end{array}$ & $\begin{array}{r}+0.9599 \\
(0.6391)\end{array}$ & & 0.00915 \\
\hline
\end{tabular}

ranges of these variables, values were calculated for their contributions and ranges of their contributions to the 24-hr percentage-shrinkage values. These calculated values, as presented in table 9-4, are estimates based on a single equation, and it may be noted that somewhat different values would be obtained by use of other equations ${ }^{9}$.

As in previous sections, the calculated-contribution values must also take into consideration the constant in the equation.

An increase in $\mathrm{C}_{3} \mathrm{~A}$ and $\mathrm{C}_{4} \mathrm{AF}$ appears to be associated with lower shrinkage values but the use also of the $\mathrm{SO}_{3}$ and the $\mathrm{C}_{3} \mathrm{~A} / \mathrm{SO}_{3}$ ratio in the equation may have affected the coefficient

- Similar computations for contributions to the shrinkage values at other ages will also be made from corresponding equations in order that the trends may be followed more easily.
TABLE 9-4. Calculated contributions of independent variables to the percentage shrinkage at $24 \mathrm{hr}$. (after the initial $24 \mathrm{hr}$. in moist-air storage) of neat-cement bars of normal consistency (SH24)

\begin{tabular}{|c|c|c|c|c|}
\hline $\begin{array}{l}\text { Inde- } \\
\text { pendent } \\
\text { variable }\end{array}$ & $\begin{array}{l}\text { Ranges of } \\
\text { variables, } \\
\text { percent }\end{array}$ & $\begin{array}{l}\text { Coefficients } \\
\text { from eq } 3 \\
\text { table } 9-3\end{array}$ & $\begin{array}{l}\text { Calculated contri- } \\
\text { butions to } \mathrm{SH} 24\end{array}$ & $\begin{array}{l}\text { Calculat- } \\
\text { ed ranges } \\
\text { of contri- } \\
\text { butions to } \\
\text { SH } 24\end{array}$ \\
\hline $\begin{array}{l}\mathrm{C}_{3} \mathrm{~A} \\
\mathrm{C}_{4} \mathrm{AF}_{\mathrm{F}} \\
\mathrm{Na}_{2} \mathrm{O} \\
\mathrm{K}_{2} \mathrm{O} \\
\mathrm{SO}_{3} \\
\mathrm{C}_{3} \mathrm{~A} / \mathrm{SO}_{3} \\
\mathrm{APF} \\
\mathrm{Ba}^{* *} \\
\mathrm{~Pa}^{* *} \\
\mathrm{Zn} \mathrm{H}^{* *} \\
\mathrm{Cr}\end{array}$ & $\begin{array}{c}0 \text { to } 15 \\
4 \text { to } 17 \\
0 \text { to } 0.75 \\
0 \text { to } 1.1 \\
1.2 \text { to } 3.6 \\
0.4 \text { to } 10.1 \\
* 2500 \text { to } 5500 \\
0 \text { to } 0.2 \\
0 \text { to } 0.5 \\
0 \text { to } 0.2 \\
0 \text { to } 0.02\end{array}$ & $\begin{array}{l}-0.00553 \\
-0.00137 \\
+0.0100 \\
+0.0200 \\
+0.0351 \\
+0.0101 \\
+0.0000046 \\
+0.0523 \\
+0.0130 \\
-0.0323 \\
+0.442\end{array}$ & $\begin{array}{r}\text { Const. }=-0.020 \\
0 \text { to }-0.083 \\
-0.005 \text { to }-0.023 \\
0 \text { to }+0.008 \\
0 \text { to }+0.022 \\
+0.042 \text { to }+0.126 \\
+0.004 \text { to }+0.102 \\
+0.012 \text { to }+0.025 \\
0 \text { to }+0.010 \\
0 \text { to }+0.006 \\
0 \text { to }-0.006 \\
0 \text { to }+0.009\end{array}$ & $\begin{array}{l}0.083 \\
0.018 \\
0.008 \\
0.022 \\
0.084 \\
0.098 \\
0.013 \\
0.010 \\
0.006 \\
0.006 \\
0.009\end{array}$ \\
\hline
\end{tabular}

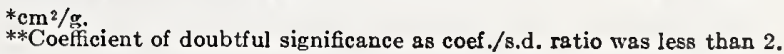


for the $\mathrm{C}_{3} \mathrm{~A}$. Differences in the $\mathrm{C}_{3} \mathrm{~A}$ and $\mathrm{SO}_{3}$ appear to be important contributors to differences in shrinkage.

\subsection{Nonrestrained Shrinkage After 6 Days Drying}

It may be noted in figure $9-4$ that $\mathrm{SiO}_{2}, \mathrm{Al}_{2} \mathrm{O}_{3}$, $\mathrm{SO}_{3}, \mathrm{~K}_{2} \mathrm{O}$, total alkali, $\mathrm{C}_{3} \mathrm{~A}$, and (air, $1: 4$ mortar) all had absolute "quadrant-sum" values greater than 11 when the shrinkage at 7 days (the first $24 \mathrm{hr}$ in moist storage) was plotted versus the individual independent variables.

The frequency distributions of the 7-day percentage-shrinkage values of the neat pastes of normal consistency of the different types of cement are presented in table 9-5. There was a considerable range of values, especially for the Type I cements, and an overlapping of the values for the cements within the various types as classified.

Equations selected from those computed to determine the various independent variables associated with the shrinkage at 7 days (the first $24 \mathrm{hr}$ in moist-air storage) of neat cement bars of normal consistency made of $\mathrm{AE}+\mathrm{NAE}$ cements, are presented in table 9-6. Equation 1 relates the shrinkage to the percentage water used for normal consistency of the neat pastes. The coef./s.d. ratio for the $W_{1}$ was less than 2 , and the reduction in variance was not significant at the 5-percent probability level (table 9-34).

TABLE 9-5. Frequency distribution of cements with respect to percentage shrinkage of neat cements of normal consistency after 6 days drying in laboratory air after $24 \mathrm{hr}$ moist-air storage (SHO7)

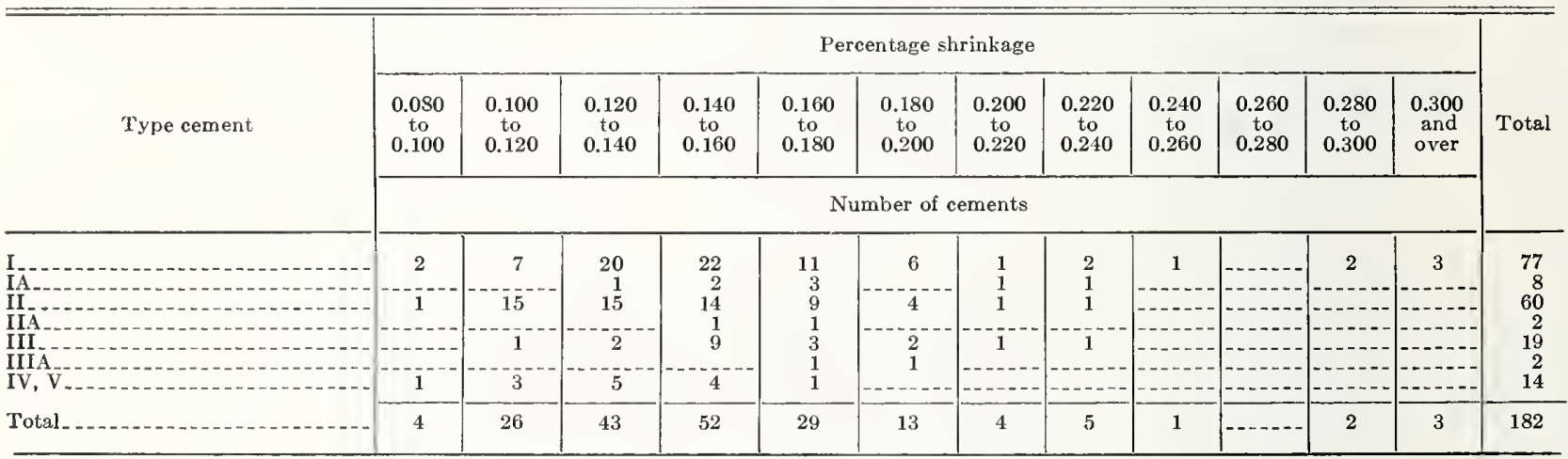

TABLE 9-6. Coefficients for equations relating the percentage shrinkage at 7 days (the first cements, to various inde

\begin{tabular}{|c|c|c|c|c|c|c|c|c|}
\hline Equation & Note & & Const. & $\mathrm{C}_{3} \mathrm{~A}$ & $\mathrm{C}_{4} \mathrm{AF}$ & $\mathrm{Al}_{2} \mathrm{O}_{3}$ & $\mathrm{Fe}_{2} \mathrm{O}_{3}$ & $\mathrm{CaO}$ \\
\hline $1,-\ldots+-1-n$ & (1) & $\begin{array}{l}\text { SHOt } \\
\text { s.d. }\end{array}$ & $\begin{array}{l}=+0.0803 \\
=(0.0356)\end{array}$ & 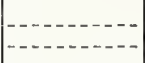 & --- & $-\cdots$ & --- & $-\overline{-1}$ \\
\hline $2 \ldots+\ldots-\ldots$ & (1) & $\begin{array}{l}\text { SHO7 } \\
\text { s.d. }\end{array}$ & $\begin{array}{l}=+0.1147 \\
=\quad(0.0176)\end{array}$ & $\begin{array}{r}*-0.00010 \\
(0.00086)\end{array}$ & $\begin{array}{c}-0.001344 \\
(0.001108)\end{array}$ & -- & & \\
\hline $3 \ldots \ldots+\ldots-n$ & (1) & $\begin{array}{l}\text { SHO7 } \\
\text { s.d. }\end{array}$ & $\begin{array}{l}=-0.0118 \\
=(0.0353)\end{array}$ & $\begin{array}{r}-0.01389 \\
(0.00383)\end{array}$ & $\begin{array}{c}-0.001382 \\
(0.001038)\end{array}$ & -- & & \\
\hline $4 \ldots \ldots+n-\ldots$ & (1) & $\begin{array}{l}\text { SHO7 } \\
\text { s.d. }\end{array}$ & $\begin{array}{l}=-0.0225 \\
=(0.0344)\end{array}$ & $\begin{array}{c}-0.01423 \\
(0.00371)\end{array}$ & $\begin{array}{r}-0.001525 \\
(0.001007)\end{array}$ & & & \\
\hline $4 A_{\ldots} \ldots$ & $\left({ }^{2}\right)$ & $\begin{array}{l}\text { SHO7 (odd) } \\
\text { s.d. }\end{array}$ & $\begin{array}{l}=-0.0143 \\
=\quad(0.0421)\end{array}$ & $\begin{array}{c}-0.01266 \\
(0.00465)\end{array}$ & $\begin{array}{c}-0.002051 \\
(0.001409)\end{array}$ & -- & & \\
\hline $4 \mathrm{~B}_{\ldots} \ldots \ldots$ & (3) & $\begin{array}{l}\text { SHO7 (even) } \\
\text { s.d. }\end{array}$ & $\begin{array}{l}=-0.0405 \\
=(0.0704)\end{array}$ & $\begin{array}{r}-0.01702 \\
(0.00745)\end{array}$ & $\begin{array}{r}*-0.001282 \\
(0.001626)\end{array}$ & 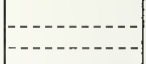 & & -- \\
\hline $5 \ldots \ldots$ & (1) & $\begin{array}{l}\text { SHO7 } \\
\text { s.d. }\end{array}$ & $\begin{array}{l}=+0.4203 \\
=(0.1291)\end{array}$ & 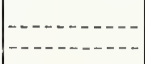 & 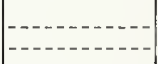 & $\begin{array}{r}* 0.00111 \\
(0.00273)\end{array}$ & $\begin{array}{c}-0.006786 \\
(0.003052)\end{array}$ & $\begin{array}{r}-0.004490 \\
(0.001878)\end{array}$ \\
\hline $6 \ldots$ & (1) & $\begin{array}{l}\text { SHO7 } \\
\text { s.d. }\end{array}$ & $\begin{array}{l}=+0.1362 \\
=\quad(0.1317)\end{array}$ & 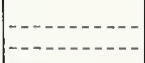 & 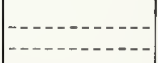 & $\begin{array}{r}-0.03343 \\
(0.00848)\end{array}$ & $\begin{array}{c}-0.005471 \\
(0.002918)\end{array}$ & $\begin{array}{r}-0.002810 \\
(0.001966)\end{array}$ \\
\hline $7 \ldots \ldots$ & (1) & $\begin{array}{l}\text { SHO7 } \\
\text { s.d. }\end{array}$ & $\begin{array}{l}=+0.1890 \\
=\quad(0.1268)\end{array}$ & | & 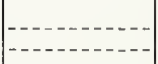 & $\begin{array}{r}-0.03553 \\
(0.00814)\end{array}$ & $\begin{array}{c}-0.006824 \\
(0.002822)\end{array}$ & $\begin{array}{r}-0.003900 \\
(0.001904)\end{array}$ \\
\hline $7 A_{\ldots} \ldots$ & $\left({ }^{2}\right)$ & $\begin{array}{l}\text { SHO7 (odd) } \\
\text { s.d. }\end{array}$ & $\begin{array}{l}=+0.3419 \\
=(0.2024)\end{array}$ & 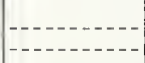 & 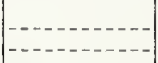 & $\begin{array}{r}-0.03072 \\
(0.01053)\end{array}$ & $\begin{array}{c}-0.010100 \\
(0.004255)\end{array}$ & $\begin{array}{r}-0.005834 \\
(0.003107)\end{array}$ \\
\hline $7 \mathrm{~B}_{-}$ & (3) & $\begin{array}{l}\text { SHO7 (even) } \\
\text { s.d. }\end{array}$ & $\begin{array}{l}=+0.0187 \\
=(0.1772)\end{array}$ & - & $----n-\ldots-1$ & $\begin{array}{c}-0.06140 \\
(0.01645)\end{array}$ & $\begin{array}{c}-0.005482 \\
(0.004054)\end{array}$ & $\begin{array}{c}-0.003327 \\
(0552.002)\end{array}$ \\
\hline
\end{tabular}


Only $\mathrm{C}_{3} \mathrm{~A}, \mathrm{C}_{4} \mathrm{AF}$, and $\mathrm{SO}_{3}$ were used as independent variables in eq 2 . The coef./s.d. ratio for $\mathrm{C}_{3} \mathrm{~A}$ was less than 1 . It may be noted that in eq 3 , where $\mathrm{C}_{3} \mathrm{~A} / \mathrm{SO}_{3}$ and four other additional independent variables were used, the coefficient for $\mathrm{C}_{3} \mathrm{~A}$ was highly significant, and that the coefficient for $\mathrm{SO}_{3}$ more than doubled. The reduction in the S.D. value was highly significant (see table 9-34). Coef./s.d. ratios for $\mathrm{C}_{4} \mathrm{AF}$ and $\mathrm{APF}$, however, were less than two. By use of the trace elements, $\mathrm{Ba}, \mathrm{P}$, and $\mathrm{Rb}$ in eqs 4 and 7 , a further significant reduction in the S.D. was attained, although $\mathrm{P}$ had a coef./s.d. ratio less than 2. In the equations for the "odds" and "evens" (eqs 4A and 4B), P and Rb had coef./ s.d. values less than one in one or the other, as may also be noted in eqs $7 \mathrm{~A}$ and $7 \mathrm{~B}$, where the oxides were used instead of the calculated compounds. Equations 5, 6, and 7, calculated using the oxides, also indicate that the coefficients for $\mathrm{Al}_{2} \mathrm{O}_{3}$ and $\mathrm{SO}_{3}$ are affected by inclusion of the $\mathrm{Al}_{2} \mathrm{O}_{3} / \mathrm{SO}_{3}$ ratio.

A comparable series of equations for the NAE cements is presented in table 9-7. The coefficients obtained were fairly similar to those of the previous table except that the coefficient for (air, 1:4 mortar) was of questionable significance when the AE cements were not included. The coef./s.d. ratio for (air, 1: 4 mortar) was less than 1 in eqs $4 \mathrm{~A}$ and $4 \mathrm{~B}$ in table 9-7. It was also less than one when this variable was included with those in eq 7. Of the minor constituents, only $\mathrm{P}$ had coef./s.d. ratios of less than 1 in the equations for the "odds" or "evens" and Rb had a coef./s.d. ratio greater than 1 in all instances.

Using the coefficients of eq 4 of table 9-7 and the ranges of the independent variables, values were calculated for their contributions and ranges of contributions to the percentage shrinkage at 7 days. These calculated values are presented in table 9-8. Increases in $\mathrm{C}_{3} \mathrm{~A}$ and $\mathrm{C}_{4} \mathrm{AF}$ were associated with lower shrinkage values when $\mathrm{SO}_{3}$ and $\mathrm{C}_{3} \mathrm{~A} / \mathrm{SO}_{3}$ were included as independent variables. All the other independent variables with coef./s.d. ratios greater than 1 had positive coefficients. Variations of $\mathrm{C}_{3} \mathrm{~A}, \mathrm{SO}_{3}$ and $\mathrm{C}_{3} \mathrm{~A} / \mathrm{SO}_{3}$ appeared to have important effects. Although the coefficient for (air, 1:4 mortar) was of doubtful significance when only the NAE cements were used in the calculations, it was probably significant when the AE cements were included as in table 9-6.

\subsection{Nonrestrained Shrinkage After 28 Days Drying}

The preliminary plots of the 28-day-shrinkage values (the first $24 \mathrm{hr}$ in moist air) of the neat cement pastes of normal consistency versus various individual independent variables are indicated in figure 9-4. It may be noted that $\mathrm{SiO}_{2}, \mathrm{Al}_{2} \mathrm{O}_{3}, \mathrm{SO}_{3}, \mathrm{~K}_{2} \mathrm{O}$, total alkali, $\mathrm{C}_{3} \mathrm{~A}, \mathrm{C}_{2} \mathrm{~S}$, $\mathrm{C}_{4} \mathrm{AF}, \mathrm{A} / \mathrm{F}$, and (air, 1: 4 mortar) had "quadrant-sum" absolute values greater than 11 .

The frequency distribution of the 28-day percentage-shrinkage values of the prisms

$24 \mathrm{hr}$ in moist-air-storage) of neat-cement bars of normal consistency made of $A E+N A E$ pendent variables (SHO7)

\begin{tabular}{|c|c|c|c|c|c|c|c|c|c|c|c|}
\hline $\mathrm{Na}_{2} \mathrm{O}$ & $\mathrm{K}_{2} \mathrm{O}$ & $\mathrm{SO}_{3}$ & $\mathrm{C} 3 \mathrm{~A} / \mathrm{SO}_{3}$ & $\mathrm{~A} !_{2} \mathrm{O}_{3} / \mathrm{SO}_{3}$ & $\begin{array}{l}\text { Air, } 1: 4 \\
\text { mortar }\end{array}$ & $\triangle P F$ & $\mathrm{Ba}$ & $P$ & $\mathrm{Rb}$ & $W_{1}$ & S.D. \\
\hline & & & & & & & & & 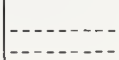 & $\begin{array}{r}+0.00274 \\
(0.00144)\end{array}$ & $\begin{array}{r}0.02790 \\
-\end{array}$ \\
\hline & & $\begin{array}{r}+0.02495 \\
(0.00617)\end{array}$ & & & & & & & & & 0.02659 \\
\hline $\begin{array}{r}+0.02825 \\
(0.01249)\end{array}$ & $\begin{array}{r}+0.04011 \\
(0.01023)\end{array}$ & $\begin{array}{r}+0.06799 \\
(0.01787)\end{array}$ & $\begin{array}{r}+0.02410 \\
(0.00689)\end{array}$ & & $\begin{array}{r}+0.00143 \\
(0.00055)\end{array}$ & $\begin{array}{r}+0.0000050 \\
(0.0000045)\end{array}$ & & & & & 0.02404 \\
\hline $\begin{array}{r}+0.03017 \\
(0.01215)\end{array}$ & $\begin{array}{r}+0.03165 \\
(0.01073)\end{array}$ & $\begin{array}{r}+0.06685 \\
(0.01727)\end{array}$ & $\begin{array}{r}+0.0 \\
(0.0\end{array}$ & & $\begin{array}{r}+0.00171 \\
(0.00054)\end{array}$ & $\begin{array}{c}+0.0000072 \\
(0.0000044)\end{array}$ & $\begin{array}{r}+0.1675 \\
(0.0698)\end{array}$ & $\begin{array}{r}+0.02401 \\
(0.01662)\end{array}$ & $\begin{array}{r}+2.632 \\
(1.115)\end{array}$ & & 0.02317 \\
\hline $\begin{array}{r}+0.03384 \\
(0.02147)\end{array}$ & $\begin{array}{r}+0.03349 \\
(0.01578)\end{array}$ & $\begin{array}{r}+0.06063 \\
(0.02147)\end{array}$ & $\begin{aligned}+0 . \\
0 .\end{aligned}$ & & $\begin{array}{r}+0.00139 \\
(0.00082)\end{array}$ & $\begin{array}{r}+0.0000099 \\
(0.0000069)\end{array}$ & $\begin{array}{c}+0.1601 \\
(0.0808)\end{array}$ & $\begin{array}{r}+0.04794 \\
(0.02185)\end{array}$ & $\begin{array}{r}*+1.292 \\
(1.639)\end{array}$ & & 0.0236 \\
\hline $\begin{array}{r}+0.02890 \\
(0.01590)\end{array}$ & $\begin{array}{r}+0.02939 \\
(0.01567)\end{array}$ & $\begin{array}{r}+0.08050 \\
(0.03558)\end{array}$ & $\begin{array}{r}+0.02988 \\
(0.01366)\end{array}$ & & $\begin{array}{r}+0.00187 \\
(0.00076)\end{array}$ & $\begin{array}{r}*+0.0000046 \\
(0.0000064)\end{array}$ & $\begin{array}{r}+0.1715 \\
(0.1619)\end{array}$ & $\begin{array}{r}*-0.01194 \\
(0.02917)\end{array}$ & $\begin{array}{r}+3.336 \\
(1.615)\end{array}$ & & $\begin{array}{r}0.02385 \\
-\end{array}$ \\
\hline & & $\begin{array}{r}+0.02176 \\
(0.00623)\end{array}$ & & & & & & & & & $\begin{array}{r}0.02622 \\
-\end{array}$ \\
\hline $\begin{array}{r}+0.02225 \\
(0.01229)\end{array}$ & $\begin{array}{r}+0.03300 \\
(0.01080)\end{array}$ & $\begin{array}{r}+0.09222 \\
(0.02272)\end{array}$ & & $\begin{array}{r}+0.05723 \\
(0.01499)\end{array}$ & $\begin{array}{r}+0.00137 \\
(0.00055)\end{array}$ & $\begin{array}{r}+0.0000046 \\
(0.0000045)\end{array}$ & & & & & $\begin{array}{r}0.02392 \\
-\end{array}$ \\
\hline $\begin{array}{r}+0.02409 \\
(0.01185)\end{array}$ & $\begin{array}{r}+0.02354 \\
(0.01113)\end{array}$ & $\begin{array}{r}+0.09462 \\
(0.02173)\end{array}$ & & $\begin{array}{r}+0.06167 \\
(0.01439)\end{array}$ & $\begin{array}{r}+0.00161 \\
(0.00053)\end{array}$ & $\begin{array}{r}+0.0000071 \\
(0.0000044)\end{array}$ & $\begin{array}{c}+0.2011 \\
(0.0696)\end{array}$ & $\begin{array}{r}+0.02851 \\
(0.01649)\end{array}$ & $\begin{array}{r}+2.432 \\
(0.099)\end{array}$ & & $\begin{array}{r}0.02285 \\
-\end{array}$ \\
\hline $\begin{array}{r}+0.03060 \\
(0.02109)\end{array}$ & $\begin{array}{r}+0.02576 \\
(0.01622)\end{array}$ & $\begin{array}{r}+0.07894 \\
(0.02678)\end{array}$ & & $\begin{array}{c}+0.05163 \\
(0.01798)\end{array}$ & $\begin{array}{r}+0.00105 \\
(0.00084)\end{array}$ & $\begin{array}{r}+0.0000116 \\
(0.0000068)\end{array}$ & $\begin{array}{c}+0.2051 \\
(0.0829)\end{array}$ & $\begin{array}{r}+0.05712 \\
(0.02205)\end{array}$ & $\begin{array}{r}*+0.989 \\
(1.685)\end{array}$ & & 0.02347 \\
\hline $\begin{array}{c}+0.02009 \\
(0.01513)\end{array}$ & $\begin{array}{r}+0.01828 \\
(0.01612)\end{array}$ & $\begin{array}{r}+0.17189 \\
(0.04657)\end{array}$ & & $\begin{array}{r}+0.11148 \\
(0.03020)\end{array}$ & $\begin{array}{r}+0.00186 \\
(0.00072)\end{array}$ & $\begin{array}{r}*+0.0000014 \\
(0.0000063)\end{array}$ & $\begin{array}{c}+0.2016 \\
(0.1527)\end{array}$ & $\begin{array}{r}*+0.01327 \\
(0.02772)\end{array}$ & $\begin{array}{r}+3.223 \\
(1.531)\end{array}$ & & 0.02266 \\
\hline
\end{tabular}


TABLE 9-7. Coefficients for equations relating the percentage shrinkage at 7 days (the cements; to various

\begin{tabular}{|c|c|c|c|c|c|c|c|c|}
\hline Equation & Note & & Const. & $\mathrm{C}_{3} \mathrm{~A}$ & $\mathrm{C}_{4 \mathrm{AF}}$ & $\mathrm{Al}_{2} \mathrm{O}_{3}$ & $\mathrm{Fe}_{2} \mathrm{O}_{3}$ & $\mathrm{CaO}$ \\
\hline $1 \ldots$ & (1) & $\begin{array}{l}\text { SHO7 } \\
\text { s.d. }\end{array}$ & $\begin{array}{l}=+0.0873 \\
=(0.0361)\end{array}$ & & & & & \\
\hline $2 \ldots$ & (1) & $\begin{array}{l}\text { SHO7 } \\
\text { s.d. }\end{array}$ & $\begin{array}{l}=+0.1223 \\
=(0.0180)\end{array}$ & $\begin{array}{r}*-0.00047 \\
(0.00087)\end{array}$ & $\begin{array}{r}-0.001504 \\
(0.001121)\end{array}$ & & & \\
\hline $3 \ldots$ & (1) & $\begin{array}{l}\text { SHO7 } \\
\text { s.d. }\end{array}$ & $\begin{array}{l}=-0.0125 \\
=(0.0350)\end{array}$ & \begin{tabular}{|c|}
-0.01666 \\
$(0.00383)$
\end{tabular} & $\begin{array}{r}-0.001841 \\
(0.001033)\end{array}$ & & & \\
\hline $4 \ldots$ & (1) & $\begin{array}{l}\text { SHO7 } \\
\text { s.d. }\end{array}$ & $\begin{array}{l}=-0.0316 \\
=(0.0346)\end{array}$ & $\begin{array}{c}-0.01649 \\
(0.00372)\end{array}$ & $\begin{array}{c}-0.001917 \\
(0.001003)\end{array}$ & & & \\
\hline 4A..- & ${ }^{(2)}$ & $\begin{array}{l}\text { SHO7 (odd) } \\
\text { s.d. }\end{array}$ & $\begin{array}{l}=-0.0320 \\
=(0.0467)\end{array}$ & $\begin{array}{c}-0.01754 \\
(0.00520)\end{array}$ & $\begin{array}{r}-0.001925 \\
(0.001748)\end{array}$ & & & \\
\hline $4 \mathrm{~B}_{-}$ & (3) & $\begin{array}{l}\text { SHO7 (even) } \\
\text { s.d. }\end{array}$ & $\begin{array}{l}=+0.0358 \\
=(0.0590)\end{array}$ & $\begin{array}{r}-0.00715 \\
(0.00625)\end{array}$ & $\begin{array}{c}-0.002268 \\
(0.001225)\end{array}$ & & & \\
\hline 5 -- & (1) & $\begin{array}{l}\text { SHO7 } \\
\text { s.d. }\end{array}$ & $\begin{array}{l}=+0.4202 \\
=(0.1332)\end{array}$ & & & $\begin{array}{r}*-0.00193 \\
(0.00230)\end{array}$ & $\begin{array}{r}-0.006827 \\
(0.003142)\end{array}$ & $\begin{array}{c}-0.004370 \\
(0.001935)\end{array}$ \\
\hline $6 \ldots$ & (1) & $\begin{array}{l}\text { SHO7 } \\
\text { s.d. }\end{array}$ & $\begin{array}{l}=+0.1503 \\
=(0.1342)\end{array}$ & & & $\begin{array}{c}-0.03578 \\
(0.00849)\end{array}$ & $\begin{array}{r}-0.006085 \\
(0.002957)\end{array}$ & $\begin{array}{c}-0.003113 \\
(0.001988)\end{array}$ \\
\hline $7 \therefore$ & (1) & $\begin{array}{l}\text { SHO7 } \\
\text { s.d. }\end{array}$ & $\begin{array}{l}=+0.2262 \\
=(0.1271)\end{array}$ & & & $\begin{array}{c}-0.04005 \\
(0.00801)\end{array}$ & $\begin{array}{c}-0.008091 \\
(0.002811)\end{array}$ & $\begin{array}{c}-0.004495 \\
(0.001899)\end{array}$ \\
\hline $7 \mathrm{~A}_{--}$ & (2) & $\begin{array}{l}\text { SHO7 (odd) } \\
\text { s.d. }\end{array}$ & $\begin{array}{l}=+0.1438 \\
=(0.2030)\end{array}$ & & & $\begin{array}{r}-0.04181 \\
(0.01065)\end{array}$ & $\begin{array}{r}-0.007077 \\
(0.004921)\end{array}$ & $\begin{array}{r}-0.003232 \\
(0.003054)\end{array}$ \\
\hline $7 \mathrm{~B}_{\ldots}$ & (3) & $\begin{array}{l}\text { SHO7 (even) } \\
\text { s.d. }\end{array}$ & $\begin{array}{l}=+0.3954 \\
=(0.1603)\end{array}$ & & & $\begin{array}{c}-0.02224 \\
(0.01544)\end{array}$ & $\begin{array}{r}-0.010587 \\
(0.003282)\end{array}$ & $\begin{array}{c}-0.006087 \\
(0.002271)\end{array}$ \\
\hline
\end{tabular}

1153 cements; $\mathrm{Avg}=0.1463 ;$ S.D. $=0.02748$.

277 cements.

376 cements.

* Coef./s.d. ratio less than 1.

TABLE 9-8. Calculated contributions of independent variables to the percentage shrinkage at 7 days (the first $24 \mathrm{hr}$. in moist-airstorage) of neat-cement bars of normal consistency. (SHOY)

\begin{tabular}{|c|c|c|c|c|}
\hline $\begin{array}{l}\text { Inde- } \\
\text { pendent } \\
\text { variable }\end{array}$ & $\begin{array}{l}\text { Ranges of } \\
\text { variables, } \\
\text { percent }\end{array}$ & $\begin{array}{l}\text { Coefficients } \\
\text { from eq } 4 \\
\text { table } 9-7\end{array}$ & $\begin{array}{l}\text { Calculated contri- } \\
\text { butions to } \mathrm{SHO7}\end{array}$ & $\begin{array}{c}\text { Calculat- } \\
\text { ed ranges } \\
\text { of contri- } \\
\text { butions to } \\
\text { SHO7 }\end{array}$ \\
\hline $\begin{array}{l}\mathrm{C}_{3} \mathrm{~A} \\
\mathrm{C}_{4} \mathrm{~A} \mathrm{~F}^{* *}- \\
\mathrm{Na}_{2} \mathrm{O}_{-} \\
\mathrm{K}_{2} \mathrm{O}_{-} \\
\mathrm{SO}_{3} \\
\mathrm{C}_{3} \mathrm{~A} / \mathrm{SO}_{3-} \\
\mathrm{Air}, 1: 4 \\
\text { mortar** } \\
\mathrm{APF}_{-} \mathrm{Ba}_{-} \\
\mathrm{Ba} \\
\mathrm{P} * \\
\mathrm{Rb}\end{array}$ & $\begin{array}{c}0 \text { to } 15 \\
4 \text { to } 17 \\
0 \text { to } 0.75 \\
0 \text { to } 1.1 \\
1.2 \text { to } 3.6 \\
0.4 \text { to } 10.1 \\
1 \text { to } 21 \\
\text { * } 2500 \text { to } 5500 \\
0 \text { to } 0.2 \\
0 \text { to } 0.5 \\
0 \text { to } 0.01\end{array}$ & $\begin{array}{l}-0.0165 \\
-0.00192 \\
+0.0313 \\
+0.0383 \\
+0.0722 \\
+0.0281 \\
+0.00144 \\
+0.0000088 \\
+0.183 \\
+0.0262 \\
+2.667\end{array}$ & $\begin{array}{r}\text { Const. }=-0.032 \\
0 \text { to }-0.248 \\
-0.008 \text { to }-0.033 \\
0 \text { to }+0.023 \\
0 \text { to }+0.042 \\
+0.086 \text { to }+0.260 \\
+0.011 \text { to }+0.284 \\
+0.001 \text { to }+0.030 \\
+0.012 \text { to }+0.048 \\
0 \text { to }+0.037 \\
0 \text { to }+0.013 \\
0 \text { to }+0.027\end{array}$ & $\begin{array}{l}0.248 \\
0.025 \\
0.023 \\
0.042 \\
0.174 \\
0.273 \\
\\
0.029 \\
0.026 \\
0.037 \\
0.013 \\
0.027\end{array}$ \\
\hline
\end{tabular}

$* \mathrm{crm}^{2} / \mathrm{g}$.

**Coefficient of doubtful significance as coef./s.d. ratio was less than 2

made of the different cements is presented in table 9-9. It may be noted that a considerable range of values was obtained with each of the different types of cement and especially with those classified as Type I cements. The highest percentage-shrinkage values were obtained with the Type I or IA cements but some of the Type I cements were also in the group with the lowest percentage shrinkage.

A selected group of equations is presented in table 9-10 to indicate the variables found to be associated with the 28-day percentage-shrinkage values of the $\mathrm{AE}+\mathrm{NAE}$ cernents. Equation 1 indicates no apparent relationship between the percentage mixing water for normal consistency and the percentage shrinkage at 28 days. The use of variables in eq 2 of this table, resulted in a significant reduction in the S.D. values (see table 9-34) although the $\mathrm{C}_{3} \mathrm{~A}$ and $\mathrm{C}_{4} \mathrm{AF}$ had coef./s.d. ratios less than 1 . With the use of the 5 additional variables in eq 3 , the variables $\mathrm{C}_{3} \mathrm{~A}$, and $\mathrm{C}_{3} \mathrm{~A} / \mathrm{SO}_{3}$ were highly significant, and $\mathrm{C}_{4} \mathrm{AF}$ had a coef./s.d. ratio greater than 1 . The additional use of the trace elements, $\mathrm{Ba}, \mathrm{P}, \mathrm{Zn}$, and $\mathrm{Rb}$ in eqs 4 and 6 resulted in a reduction in variance significant at the 1-percent probability level. It may be noted that in equations calculated for the "odds" and "evens" in the array of cements (eqs $4 \mathrm{~A}, 4 \mathrm{~B}, 6 \mathrm{~A}$, and $6 \mathrm{~B})$ there were instances where $\mathrm{C}_{4} \mathrm{AF}, \mathrm{SiO}_{2}$, $\mathrm{Fe}_{2} \mathrm{O}_{3}, \mathrm{MgO}, \mathrm{APF}$, (air, 1:4 mortar), $\mathrm{P}, \mathrm{Zn}$, and $\mathrm{Rb}$ had coef./s.d. ratios less than 1 in one or more of the equations for the smaller groups.

A comparable series of equations for the NAE cements is presented in table 9-11. In these equations the (air, 1:4 mortar) had coef./s.d. ratios less than 1 in trial equations and was not included among the independent variables. The coefficients for the other independent variables in table 9-11 appear to be in reasonable agreement with corresponding coefficients in table 9-10 where the AE cements were included.

Contributions and ranges of contributions to the shrinkage at 28 days of the neat cement bars of normal consistency are presented in table 9-12. The coefficients in eq 3 of table 9-11 were used as a basis for these calculations. The three variables $\mathrm{C}_{3} \mathrm{~A}, \mathrm{SO}_{3}$, and $\mathrm{C}_{3} \mathrm{~A} / \mathrm{SO}_{3}$ when used together in a multivariable equation had the highest values for the calculated ranges of 
first $24 \mathrm{hr}$ in moist-air storage) of neat-cement bars of normal consistency made of $N A E$ independent variables

\begin{tabular}{|c|c|c|c|c|c|c|c|c|c|c|c|}
\hline $\mathrm{Na}_{2} \mathrm{O}$ & $\mathrm{K}_{2} \mathrm{O}$ & $\mathrm{SO}_{3}$ & $\mathrm{C}_{3} \mathrm{~A} / \mathrm{SO}_{3}$ & $\mathrm{Al}_{2} \mathrm{O}_{3} / \mathrm{SO}_{3}$ & $\begin{array}{l}\text { Air, 1:4 } \\
\text { mortar }\end{array}$ & $\triangle P F$ & $\mathrm{Ba}$ & $\mathrm{P}$ & $\mathrm{I} \mathrm{tb}$ & $W_{1}$ & S.D. \\
\hline - & $\begin{array}{l}- \\
-\end{array}$ & $\begin{array}{r}+0.02266 \\
(0.00630)\end{array}$ & & & & & & & & $\begin{array}{r}+0.00239 \\
(0.00146)\end{array}$ & $\begin{array}{r}0.02733 \\
0.02633 \\
\hdashline\end{array}$ \\
\hline $\begin{array}{r}+0.02475 \\
(0.01322)\end{array}$ & $\begin{array}{r}+0.04064 \\
(0.01013)\end{array}$ & $\begin{array}{r}+0.08038 \\
(0.01685)\end{array}$ & $\begin{array}{r}+0.02814 \\
(0.00686)\end{array}$ & - & $\begin{array}{r}+0.002116 \\
(0.001253)\end{array}$ & & & & & & 0.02367 \\
\hline $\begin{array}{r}+0.03133 \\
(0.01274)\end{array}$ & $\begin{array}{r}+0.03833 \\
(0.01091)\end{array}$ & $\begin{array}{r}+0.07218 \\
(0.01721)\end{array}$ & $\begin{array}{c}+0.02807 \\
(0.00660)\end{array}$ & & $\begin{array}{r}+0.001444 \\
(0.001217)\end{array}$ & $\begin{array}{r}+0.0000088 \\
(0.0000044)\end{array}$ & $\begin{array}{r}+0.1828 \\
(0.0684)\end{array}$ & $\begin{array}{r}+0.02623 \\
(0.01653)\end{array}$ & $\begin{array}{r}+2.667 \\
(1.104)\end{array}$ & & $\begin{array}{r}0.02255 \\
-.-1 .\end{array}$ \\
\hline $\begin{array}{c}+0.02664 \\
(0.02410)\end{array}$ & $\begin{array}{r}+0.04722 \\
(0.01767)\end{array}$ & $\begin{array}{c}+0.06717 \\
(0.02410)\end{array}$ & $\begin{array}{r}+0.02976 \\
(0.00890)\end{array}$ & & $\begin{array}{c}*+0.001141 \\
(0.002186)\end{array}$ & $\begin{array}{c}+0.0000124 \\
(0.0000079)\end{array}$ & $\begin{array}{c}+0.1053 \\
(0.0867)\end{array}$ & $\begin{array}{r}+0.04855 \\
(0.02428)\end{array}$ & $\begin{array}{r}+2.615 \\
(1.786)\end{array}$ & & $\begin{array}{r}0.02483 \\
-\end{array}$ \\
\hline $\begin{array}{r}+0.03270 \\
(0.01411)\end{array}$ & $\begin{array}{r}+0.02753 \\
(0.01347)\end{array}$ & $\begin{array}{r}+0.04171 \\
(0.02917)\end{array}$ & $\begin{array}{r}+0.01167 \\
(0.01148)\end{array}$ & $\mid$ & $\begin{array}{r}*+0.000685 \\
(0.001399)\end{array}$ & $\begin{array}{c}+0.0000069 \\
(0.0000054)\end{array}$ & $\begin{array}{r}0.4800 \\
(0.1437)\end{array}$ & $\begin{array}{r}*-0.01348 \\
(0.02373)\end{array}$ & $\begin{array}{r}+1.795 \\
(1.395)\end{array}$ & & 0.01973 \\
\hline$-2 .-1$ & $-\ldots$ & $\begin{array}{r}+0.01945 \\
(0.00638)\end{array}$ & 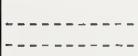 & & & $-\cdots$ & & $-\cdots$ & & & $\begin{array}{r}0.02598 \\
-\end{array}$ \\
\hline $\begin{array}{r}+0.01907 \\
(0.01309)\end{array}$ & $\begin{array}{r}+0.03609 \\
(0.01122)\end{array}$ & $\begin{array}{c}+0.09353 \\
(0.02275)\end{array}$ & - & $\begin{array}{r}+0.05995 \\
(0.01490)\end{array}$ & $\begin{array}{r}+0.001950 \\
(0.001249)\end{array}$ & $\begin{array}{r}+0.0000058 \\
(0.0000046)\end{array}$ & & & & -- & 0.02356 \\
\hline $\begin{array}{r}+0.02928 \\
(0.01149)\end{array}$ & $\begin{array}{r}+0.03082 \\
(0.01104)\end{array}$ & $\begin{array}{r}+0.10146 \\
(0.02135)\end{array}$ & & $\begin{array}{r}+0.06712 \\
(0.01411)\end{array}$ & $\ldots$ & $\begin{array}{r}+0.0000090 \\
(0.0000044)\end{array}$ & $\begin{array}{r}+0.2233 \\
(0.0682)\end{array}$ & $\begin{array}{c}+0.03461 \\
(0.01610)\end{array}$ & $\begin{array}{r}+2.511 \\
(1.087)\end{array}$ & & 0.02224 \\
\hline $\begin{array}{r}+0.02383 \\
(0.02184)\end{array}$ & $\begin{array}{r}+0.04504 \\
(0.01726)\end{array}$ & $\begin{array}{r}+0.09417 \\
(0.02752)\end{array}$ & & $\begin{array}{r}+0.06910 \\
(0.01805)\end{array}$ & & $\begin{array}{r}+0.0000125 \\
(0.0000078)\end{array}$ & $\begin{array}{r}+0.1391 \\
(0.0872)\end{array}$ & $\begin{array}{r}+0.05939 \\
(0.02295)\end{array}$ & $\begin{array}{c}+2.363 \\
(1.752)\end{array}$ & - & 0.02444 \\
\hline $\begin{array}{c}+0.02927 \\
(0.01224)\end{array}$ & $\begin{array}{r}+0.01372 \\
(0.01345)\end{array}$ & $\begin{array}{r}+0.06602 \\
(0.04359)\end{array}$ & & $\begin{array}{r}+0.03899 \\
(0.02853)\end{array}$ & & $\begin{array}{r}+0.0000080 \\
(0.0000053)\end{array}$ & $\begin{array}{r}+0.5488 \\
(0.1373)\end{array}$ & $\begin{array}{r}* 0.01109 \\
(0.02259)\end{array}$ & $\begin{array}{r}+1.644 \\
(1.326\end{array}$ & & 0.01877 \\
\hline
\end{tabular}

TABLE 9-9. Frequency distribution of cements with respect to percentage shrinkage of neat cements of normal consistency after 27 days drying in laboratory air following $24 \mathrm{hr}$ moist-air curing (SH28)

\begin{tabular}{|c|c|c|c|c|c|c|c|c|c|c|c|c|c|c|}
\hline \multirow{3}{*}{ Type cement } & \multicolumn{13}{|c|}{ Percentage slırinkage } & \multirow{3}{*}{ Total } \\
\hline & $\begin{array}{c}0.14 \\
\text { to } \\
0.16\end{array}$ & $\begin{array}{c}0.16 \\
\text { to } \\
0.18\end{array}$ & $\begin{array}{c}0.18 \\
\text { to } \\
0.20\end{array}$ & $\begin{array}{l}0.20 \\
\text { to } \\
0.22\end{array}$ & $\begin{array}{c}0.22 \\
\text { to } \\
0.24\end{array}$ & $\begin{array}{c}0.24 \\
\text { to } \\
0.26\end{array}$ & $\begin{array}{c}0.26 \\
\text { to } \\
0.28\end{array}$ & $\begin{array}{c}0.28 \\
\text { to } \\
0.30\end{array}$ & $\begin{array}{c}0.30 \\
\text { to } \\
0.32\end{array}$ & $\begin{array}{c}0.32 \\
\text { to } \\
0.34\end{array}$ & $\begin{array}{c}0.34 \\
\text { to } \\
0.36\end{array}$ & $\begin{array}{c}0.36 \\
\text { to } \\
0.38\end{array}$ & $\begin{array}{l}0.38 \\
\text { and } \\
\text { over }\end{array}$ & \\
\hline & \multicolumn{13}{|c|}{ Number of cements } & \\
\hline$I_{--}$ & 2 & 5 & 11 & 14 & 17 & 6 & 10 & 4 & ..... & 1 & 2 & 2 & 3 & 77 \\
\hline A & 3 & 8 & 12 & $\begin{array}{r}3 \\
14\end{array}$ & $\frac{1}{7}$ & $\begin{array}{l}1 \\
6\end{array}$ & $\begin{array}{l}1 \\
5\end{array}$ & $\begin{array}{l}1 \\
3\end{array}$ & 2 & & & & & $\begin{array}{r}8 \\
60\end{array}$ \\
\hline & - & - & 3 & 2 & 7 & $\frac{1}{2}$ & 4 & 1 & ..... & $\ldots$ & -1 & -.- & ... & 19 \\
\hline $\mathrm{IV}, \mathrm{v}$ & 2 & $\overline{1}$ & 2 & $\frac{1}{7}$ & $\bar{i}^{-}$ & . & $\frac{1}{1}$ & - n & - & - n- & $-\cdots$ & - & - n & ${ }_{14}^{2}$ \\
\hline Total _.. & 7 & 14 & 28 & 41 & 34 & 16 & 22 & 9 & 2 & 1 & 3 & 2 & 3 & 182 \\
\hline
\end{tabular}

contributions to the 28-day shrinkage-values. Other independent variables, such as the alkalies and $\mathrm{Ba}$, also appear associated with the shrinkage values.

\subsection{Nonrestrained Shrinkage After 6 Months Drying}

In the preliminary plots of the 6-months shrinkage versus various individual independent variables it may be noted in figure 9-4 that $\mathrm{SiO}_{2}, \mathrm{MgO}, \mathrm{SO}_{3}, \mathrm{~K}_{2} \mathrm{O}$, total alkali, $\mathrm{C}_{2} \mathrm{~S}$, $\mathrm{A} / \mathrm{F}$, and (air, 1:4 mortar) had absolute "quadrant-sum" values greater than 11 .

The frequency distributions of the different types of cements with respect to the shrinkage of neat cements of normal consistency after 6 months drying are presented in table 9-13. As in the frequency-distribution tables at the earlier ages (tables 9-1, 9-4 and 9-9) there was a spread of values of the cements within each of the types, especially for the Type I cements, and an overlapping of the values obtained for the cements of the different types.

Equations selected from those computed to determine the various independent variables associated with the 6-month-shrinkage values of $\mathrm{AE}+\mathrm{NAE}$ cements are presented in table 9-14. With the use of commonly determined variables in eqs 1 or 3 there was a highly significant reduction in the S.D. values, (see table 9-34) and, with the additional trace elements, 
T.BLE 9-10. Coefficients for equations relating the percentage shrinkage at 28 days (the first cements, to various inde

\begin{tabular}{|c|c|c|c|c|c|c|c|c|c|c|}
\hline Equation & Note & & Const. & $\mathrm{C}_{3} \mathrm{~A}$ & $\mathrm{C}_{4} \mathrm{AF}$ & $\mathrm{SiO}_{2}$ & $\mathrm{Al}_{2} \mathrm{O}_{3}$ & $\mathrm{He}_{2} \mathrm{O}_{3}$ & $\mathrm{MgO}$ & $\mathrm{Na}_{2} \mathrm{O}$ \\
\hline $1 \ldots \ldots$ & (1) & $\begin{array}{l}\text { SH } 28 \\
\text { s.d. }\end{array}$ & $\begin{array}{l}=+0.1935 \\
=(0.0508)\end{array}$ & -- & -- & & & & $-\cdots$ & $\cdots$ \\
\hline $2 \ldots$ & (1) & $\begin{array}{l}\text { SH } 28 \\
\text { s.d. }\end{array}$ & $\begin{array}{l}=+0.1297 \\
=(0.0525)\end{array}$ & $\begin{array}{r}*-0.00373 \\
(0.00567)\end{array}$ & $\begin{array}{r}*-0.00059 \\
(0.00160)\end{array}$ & $-\cdots$ & & & & \\
\hline $3 \ldots \ldots \ldots$ & (1) & $\begin{array}{l}\text { SH } 28 \\
\text { s.d. }\end{array}$ & $\begin{array}{l}=+0.0119 \\
=(0.0488)\end{array}$ & $\begin{array}{c}-0.01643 \\
(0.00521)\end{array}$ & $\begin{array}{c}-0.001491 \\
(0.001392)\end{array}$ & & & & $\begin{array}{c}+0.003261 \\
(0.002317)\end{array}$ & $\begin{array}{r}+0.07957 \\
(0.01674)\end{array}$ \\
\hline $4 \ldots$ & (1) & $\begin{array}{l}\text { SH28 } \\
\text { s.d. }\end{array}$ & $\begin{array}{l}=-0.0129 \\
=(0.0475)\end{array}$ & $\begin{array}{c}-0.01756 \\
(0.00496)\end{array}$ & $\begin{array}{r}-0.001545 \\
(0.001329)\end{array}$ & & & - & $\begin{array}{r}+0.004797 \\
(0.002292)\end{array}$ & $\begin{array}{r}+0.08660 \\
(0.01614)\end{array}$ \\
\hline $4 \mathrm{~A} \ldots$ & $\left({ }^{2}\right)$ & $\begin{array}{l}\text { SH28 (odd) } \\
\text { s.d. }\end{array}$ & $\begin{array}{l}=-0.0182 \\
=(0.0577)\end{array}$ & $\begin{array}{c}-0.01657 \\
(0.00600)\end{array}$ & $\begin{array}{c}-0.003002 \\
(0.001769)\end{array}$ & & & & $\begin{array}{r}+0.008882 \\
(0.003351)\end{array}$ & $\begin{array}{r}+0.07326 \\
(0.02791)\end{array}$ \\
\hline $4 \mathrm{~B}_{-}$ & $\left({ }^{3}\right)$ & $\begin{array}{l}\text { SH28 (even) } \\
\text { s.d. }\end{array}$ & $\begin{array}{l}=-0.0365 \\
=(0.0976)\end{array}$ & $\begin{array}{c}-0.02032 \\
(0.01032)\end{array}$ & $\begin{array}{r}*-0.000222 \\
(0.000222)\end{array}$ & & & & $\begin{array}{c}*+0.002062 \\
(0.003448)\end{array}$ & $\begin{array}{r}+0.09162 \\
(0.02169)\end{array}$ \\
\hline $5 \ldots$ & (1) & $\begin{array}{l}\text { SH28 } \\
\text { s.d. }\end{array}$ & $\begin{array}{l}=+0.2455 \\
=(0.1387)\end{array}$ & & - & $\begin{array}{r}-0.00751 \\
(0.00409)\end{array}$ & $\begin{array}{r}-0.03898 \\
(0.01108)\end{array}$ & $\begin{array}{r}-0.00822 \\
(0.00354)\end{array}$ & 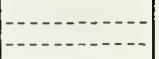 & $\begin{array}{r}+0.07956 \\
(0.01585)\end{array}$ \\
\hline $6 \ldots$ & (1) & $\begin{array}{l}\text { SH28 } \\
\text { s.d. }\end{array}$ & $\begin{array}{l}=+0.1299 \\
=\quad(0.1627)\end{array}$ & & & $\begin{array}{c}-0.00580 \\
(0.00464)\end{array}$ & $\begin{array}{r}-0.04133 \\
(0.01108)\end{array}$ & $\begin{array}{r}-0.00779 \\
(0.00354)\end{array}$ & $\begin{array}{c}+0.003964 \\
(0.002477)\end{array}$ & $\begin{array}{r}+0.07996 \\
(0.01573)\end{array}$ \\
\hline $6 A_{\ldots} \ldots \ldots$ & $\left({ }^{2}\right)$ & $\begin{array}{l}\text { SH28 (odd) } \\
\text { s.d. }\end{array}$ & $\begin{array}{l}=+0.3095 \\
=\quad(0.2447)\end{array}$ & & & $\begin{array}{r}-0.01057 \\
(0.00731)\end{array}$ & $\begin{array}{r}-0.03685 \\
(0.01372)\end{array}$ & $\begin{array}{r}-0.01272 \\
(0.00486)\end{array}$ & $\begin{array}{c}+0.006216 \\
(0.003616)\end{array}$ & $\begin{array}{r}+0.06422 \\
(0.02713)\end{array}$ \\
\hline $6 \mathrm{~B} \ldots \ldots \ldots$ & $\left({ }^{3}\right)$ & $\begin{array}{l}\text { SH28 (even) } \\
\text { s.d. }\end{array}$ & $\begin{array}{l}=-0.2049 \\
=(0.2645)\end{array}$ & & & $\begin{array}{r}*-0.00066 \\
(0.00652)\end{array}$ & $\begin{array}{c}-0.06752 \\
(0.02260)\end{array}$ & $\begin{array}{r}*-0.00310 \\
(0.00548)\end{array}$ & $\begin{array}{r}*-0.003007 \\
(0.003676)\end{array}$ & $\begin{array}{r}+0.08453 \\
(0.02068)\end{array}$ \\
\hline
\end{tabular}

1165 cements; $\mathrm{Avg}=0.2247$; S.D. $=0.03976, \quad 283$ cements. $\quad 382$ cements. $\quad *$ Coef. $/$ s.d. ratio less than 1.

TABLE 9-11. Coefficients for equations relating the percentage shrinkage at 28 days (the cements, to various inde

\begin{tabular}{|c|c|c|c|c|c|c|c|c|}
\hline Equation & Note & & Const. & $\mathrm{C}_{3} \mathrm{~A}$ & $\mathrm{C}_{4} \mathrm{AF}$ & $\mathrm{SiO}_{2}$ & $\mathrm{Al}_{2} \mathrm{O}_{3}$ & $\mathrm{Fe}_{2} \mathrm{O}_{3}$ \\
\hline $1 \ldots \ldots$ & (1) & $\begin{array}{l}\text { SH28 } \\
\text { s.d. }\end{array}$ & $\begin{array}{l}=+0.1256 \\
=(0.0533)\end{array}$ & $\begin{array}{c}-0.00616 \\
(0.00584)\end{array}$ & $\begin{array}{r}*-0.00096 \\
(0.00163)\end{array}$ & 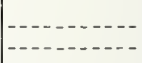 & $-\ldots$ & $\ldots$ \\
\hline 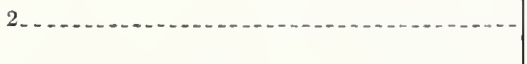 & (1) & $\begin{array}{l}\text { SH } 28 \\
\text { s.d. }\end{array}$ & $\begin{array}{l}=+0.2251 \\
=(0.0477)\end{array}$ & $\begin{array}{c}-0.01761 \\
(0.00520)\end{array}$ & $\begin{array}{r}-0.002184 \\
(0.001382)\end{array}$ & - - & $-\cdots$ & - $\ldots \ldots$ \\
\hline 3. & (1) & $\begin{array}{l}\text { SH28 } \\
\text { s.d. }\end{array}$ & $\begin{array}{l}=-0.0228 \\
=(0.0466)\end{array}$ & $\begin{array}{c}-0.02040 \\
(0.00491)\end{array}$ & $\begin{array}{r}-0.002171 \\
(0.001295)\end{array}$ & - & $\mid$\begin{tabular}{|c|} 
\\
$-\ldots \ldots n$ \\
$-\cdots$
\end{tabular} & - \\
\hline 3A. & $\left({ }^{2}\right)$ & $\begin{array}{l}\text { SH28 (odd) } \\
\text { s.d. }\end{array}$ & $\begin{array}{l}=-0.0192 \\
=(0.0651)\end{array}$ & $\begin{array}{c}-0.02091 \\
(0.00701)\end{array}$ & $\begin{array}{r}*-0.002131 \\
(0.002357)\end{array}$ & 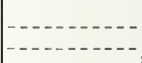 & $-\ldots$ & - \\
\hline $3 B_{\ldots} \ldots \ldots \ldots \ldots n$ & $\left({ }^{(}\right)$ & $\begin{array}{l}\text { SH28 (even) } \\
\text { s.d. }\end{array}$ & $\begin{array}{l}=+0.0492 \\
=\quad(0.0703)\end{array}$ & $\begin{array}{c}-0.00912 \\
(0.00737)\end{array}$ & $\begin{array}{r}-0.002686 \\
(0.001456)\end{array}$ & $\mid-\ldots$ & $-\cdots$ & - \\
\hline 4. & $(1)$ & $\begin{array}{l}\text { SH28 } \\
\text { s.d. }\end{array}$ & $\begin{array}{l}=+0.2616 \\
=\quad(0.1400)\end{array}$ & 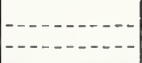 & - & $\begin{array}{r}-0.00831 \\
(0.00416)\end{array}$ & $\begin{array}{c}-0.04420 \\
(0.01119)\end{array}$ & $\begin{array}{r}-0.008559 \\
(0.003566)\end{array}$ \\
\hline $5 \ldots \ldots$ & (1) & $\begin{array}{l}\text { SH28 } \\
\text { s.d. }\end{array}$ & $\begin{array}{l}=+0.1389 \\
=(0.1601)\end{array}$ & & & $\begin{array}{c}-0.00627 \\
(0.00460)\end{array}$ & $\begin{array}{r}-0.04723 \\
(0.01093)\end{array}$ & $\begin{array}{r}-0.008560 \\
(0.003455)\end{array}$ \\
\hline $5 \mathrm{~A} \ldots$ & $(2)$ & $\begin{array}{l}\text { SH28 (odd) } \\
\text { s.d. }\end{array}$ & $\begin{array}{l}=+0.2407 \\
=(0.2606)\end{array}$ & & & $\begin{array}{r}-0.01002 \\
(0.00787)\end{array}$ & $\begin{array}{r}-0.05521 \\
(0.01562)\end{array}$ & $\begin{array}{c}-0.009743 \\
(0.006340)\end{array}$ \\
\hline $5 B$. & $\left({ }^{3}\right)$ & $\begin{array}{l}\text { SH28 (even) } \\
\text { s.d. }\end{array}$ & $\begin{array}{l}=+0.2215 \\
=(0.2154)\end{array}$ & & & $\begin{array}{r}*-0.00405 \\
(0.00519)\end{array}$ & $\begin{array}{r}* 0.00953 \\
(0.01929)\end{array}$ & $\begin{array}{c}-0.010306 \\
(0.003670)\end{array}$ \\
\hline
\end{tabular}

1153 cements. Avg $=0.2228 ;$ S.D. $=0.03937$.

277 cements. $\quad 376$ cements.

* Coef./8,d. ratio less than 1 . 
$24 \mathrm{hr}$ in moist-air storage) of neat-cement bars of normal consistency made of $A E+N A E$ pendent variables (SH28)

\begin{tabular}{|c|c|c|c|c|c|c|c|c|c|c|c|}
\hline $\mathrm{K}_{2} \mathrm{O}$ & $\mathrm{SO}_{3}$ & $\mathrm{C}_{3} \mathrm{~A} / \mathrm{SO}_{3}$ & $\mathrm{Al}_{2} \mathrm{O}_{3} / \mathrm{SO}_{3}$ & $A P F$ & $\begin{array}{l}\text { Air, } 1: 4 \\
\text { mortar }\end{array}$ & $\mathrm{Ba}$ & $\mathrm{P}$ & $\mathrm{Zn}$ & $\mathrm{Rb}$ & $W_{1}$ & S.D. \\
\hline & $\begin{array}{r}+0.04390 \\
(0.02544)\end{array}$ & $\begin{array}{c}0.01095 \\
+0.01041)\end{array}$ & -- & $\ldots$ & - & & - & & $\cdots$ & $\begin{array}{c}*+0.0013 \\
(0.0021) \\
\end{array}$ & $\begin{array}{r}0.03983 \\
0.03829 \\
\hdashline\end{array}$ \\
\hline $\begin{array}{r}+0.08193 \\
(0.01434)\end{array}$ & $\begin{array}{r}+0.07160 \\
(0.02432)\end{array}$ & $\begin{array}{c}+0.03038 \\
(0.00939)\end{array}$ & $-\ldots$ & $\begin{array}{c}+0.0000072 \\
(0.0000060)\end{array}$ & $\begin{array}{c}+0.00087 \\
(0.00074)\end{array}$ & | & $-\cdots$ & & & -- & $\begin{array}{r}0.03217 \\
--.--\end{array}$ \\
\hline $\begin{array}{r}+0.06879 \\
(0.01476)\end{array}$ & $\begin{array}{r}+0.07198 \\
(0.02310)\end{array}$ & $\begin{array}{r}+0.03279 \\
(0.00892)\end{array}$ & & $\begin{array}{c}+0.0000106 \\
(0.0000058)\end{array}$ & $\begin{array}{c}+0.00112 \\
(0.00071)\end{array}$ & $\begin{array}{c}+0.2887 \\
(0.0957)\end{array}$ & $\begin{array}{c}+0.04454 \\
(0.02202)\end{array}$ & $\begin{array}{r}-0.09902 \\
(0.09034)\end{array}$ & $\begin{array}{r}+2.910 \\
(1.477)\end{array}$ & & 0.03050 \\
\hline $\begin{array}{c}+0.07933 \\
(0.02065)\end{array}$ & $\begin{array}{c}+0.06632 \\
(0.02794)\end{array}$ & $\begin{array}{r}+0.03077 \\
(0.01061)\end{array}$ & & $\begin{array}{r}+0.0000160 \\
(0.0000087)\end{array}$ & $\begin{array}{r}*+0.00071 \\
(0.00105)\end{array}$ & $\begin{array}{r}+0.3222 \\
(0.1085)\end{array}$ & $\begin{array}{c}+0.07274 \\
(0.02754)\end{array}$ & $\begin{array}{r}*+0.02507 \\
(0.16517)\end{array}$ & $\begin{array}{r}*+1.845 \\
(1.127)\end{array}$ & & $\begin{array}{r}0.02967 \\
-\end{array}$ \\
\hline $\begin{array}{c}+0.06265 \\
(0.02287)\end{array}$ & $\begin{array}{r}+0.08792 \\
(0.04916)\end{array}$ & $\begin{array}{r}+0.03841 \\
(0.01885)\end{array}$ & $-\ldots$ & $\begin{array}{r}*+0.0000074 \\
(0.0000089)\end{array}$ & $\begin{array}{r}+0.00122 \\
(0.00103)\end{array}$ & $\begin{array}{r}+0.2746 \\
(0.2294)\end{array}$ & $\begin{array}{r}*+0.00272 \\
(0.04030)\end{array}$ & $\begin{array}{r}-0.1283 \\
(0.1189)\end{array}$ & $\begin{array}{c}+3.210 \\
(2.214)\end{array}$ & -- & 0.03244 \\
\hline $\begin{array}{c}+0.08333 \\
(0.01264)\end{array}$ & $\begin{array}{c}+0.08251 \\
(0.02923)\end{array}$ & 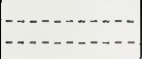 & $\begin{array}{r}+0.05713 \\
(0.01950)\end{array}$ & - & 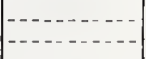 & - & $\mid$ & 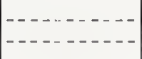 & $\mid-----\cdots$ & & 0.03217 \\
\hline $\begin{array}{r}+0.06610 \\
(0.01480)\end{array}$ & $\begin{array}{c}+0.08873 \\
(0.02995)\end{array}$ & $-\cdots$ & $\begin{array}{c}+0.06750 \\
(0.01929)\end{array}$ & $\begin{array}{r}+0.0000070 \\
(0.0000062)\end{array}$ & $\begin{array}{c}+0.00122 \\
(0.00071)\end{array}$ & $\begin{array}{c}+0.3321 \\
(0.0941)\end{array}$ & $\begin{array}{c}+0.04125 \\
(0.02191)\end{array}$ & & $\begin{array}{c}+3.000 \\
(1.473)\end{array}$ & & 0.03043 \\
\hline $\begin{array}{c}+0.06999 \\
(0.02150)\end{array}$ & $\begin{array}{r}+0.06113 \\
(0.03508)\end{array}$ & 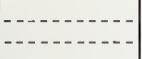 & $\begin{array}{c}+0.05064 \\
(0.02275)\end{array}$ & $\begin{array}{c}+0.0000108 \\
(0.0000096)\end{array}$ & $\begin{array}{r}+0.00087 \\
(0.00105)\end{array}$ & $\begin{array}{r}+0.3331 \\
(0.1073\end{array}$ & $\begin{array}{c}+0.07419 \\
(0.02759)\end{array}$ & - & $\begin{array}{r}*+1.713 \\
(2.135)\end{array}$ & -- & $\begin{array}{r}0.02967 \\
--.--\end{array}$ \\
\hline $\begin{array}{c}+0.05808 \\
(0.02220)\end{array}$ & $\begin{array}{r}+0.18688 \\
(0.06774)\end{array}$ & $-\cdots$ & $\begin{array}{c}+0.12983 \\
(0.04293)\end{array}$ & $\begin{array}{r}+0.0000040 \\
(0.0000091)\end{array}$ & $\begin{array}{c}+0.00130 \\
(0.00099)\end{array}$ & $\begin{array}{r}+0.3765 \\
(0.2134)\end{array}$ & $\begin{array}{r}*-0.00819 \\
(0.03840)\end{array}$ & $-\cdots-$ & $\begin{array}{r}+3.446 \\
(2.140)\end{array}$ & --- & 0.03136 \\
\hline
\end{tabular}

first $24 \mathrm{hr}$ in moist-air storage) of neat-cement bars of normal consistency made of NAE pendent variables (SH28)

\begin{tabular}{|c|c|c|c|c|c|c|c|c|c|c|c|}
\hline $\mathrm{MgO}$ & $\mathrm{Na}_{2} \mathrm{O}$ & $\mathrm{K}_{2} \mathrm{O}$ & $\mathrm{SO}_{3}$ & $\mathrm{C}_{3} \mathrm{~A} / \mathrm{SO}_{3}$ & $\mathrm{Al}_{2} \mathrm{O}_{3} / \mathrm{SO}_{3}$ & $\mathrm{APF}$ & $\mathrm{Ba}$ & $\mathrm{P}$ & $\mathrm{Zn}$ & $\mathrm{Rb}$ & S.D. \\
\hline & & & $\begin{array}{r}+0.04961 \\
(0.02601)\end{array}$ & $\begin{array}{c}+0.01447 \\
(0.01064)\end{array}$ & $\begin{array}{ll}-- \\
---\end{array}$ & $-\cdots$ & & - & & $-\cdots$ & $\begin{array}{r}0.03826 \\
-\end{array}$ \\
\hline 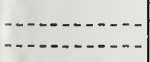 & $\begin{array}{c}+0.08421 \\
(0.01636)\end{array}$ & $\begin{array}{r}+0.09857 \\
(0.01361)\end{array}$ & $\begin{array}{c}+0.07168 \\
(0.02399)\end{array}$ & $\begin{array}{r}+0.0 \\
(0.0\end{array}$ & - - - - - - - & $\begin{array}{r}+0.0000094 \\
(0.0000061)\end{array}$ & $-\cdots-1$ & -- & $\ldots$ & $-\cdots$ & 0.03180 \\
\hline $\begin{array}{c}+0.005386 \\
(0.002268)\end{array}$ & $\begin{array}{c}+0.09205 \\
(0.01543)\end{array}$ & $\begin{array}{c}+0.07790 \\
(0.01449)\end{array}$ & $\begin{array}{r}+0.07884 \\
(0.02260)\end{array}$ & $\begin{array}{r}+0.03679 \\
(0.00877)\end{array}$ & & $\begin{array}{c}+0.0000133 \\
(0.0000057)\end{array}$ & $\begin{array}{c}+0.3194 \\
(0.0933)\end{array}$ & $\begin{array}{r}+0.04893 \\
(0.02137)\end{array}$ & $\begin{array}{r}-0.09635 \\
(0.08742)\end{array}$ & $\begin{array}{r}+3.021 \\
(1.450)\end{array}$ & $\begin{array}{r}0.02948 \\
-\end{array}$ \\
\hline $\begin{array}{c}+0.003992 \\
(0.003523)\end{array}$ & $\begin{array}{r}+0.08144 \\
(0.03045)\end{array}$ & $\begin{array}{c}+0.09711 \\
(0.02339)\end{array}$ & $\begin{array}{r}+0.06935 \\
(0.03229)\end{array}$ & $\begin{array}{c}+0.03789 \\
(0.01219)\end{array}$ & & $\begin{array}{c}+0.0000167 \\
(0.0000107)\end{array}$ & $\begin{array}{r}+0.2128 \\
(0.1232)\end{array}$ & $\begin{array}{r}+0.07777 \\
(0.03130)\end{array}$ & $\begin{array}{r}*+0.07214 \\
(0.13900)\end{array}$ & $\begin{array}{r}*+2.412 \\
(2.430)\end{array}$ & $\begin{array}{r}0.03365 \\
-----\end{array}$ \\
\hline $\begin{array}{c}+0.008647 \\
(0.002813)\end{array}$ & $\begin{array}{c}+0.08983 \\
(0.01526)\end{array}$ & $\begin{array}{c}+0.05078 \\
(0.01676)\end{array}$ & $\begin{array}{r}+0.04069 \\
(0.03419)\end{array}$ & $\begin{array}{r}+0.01778 \\
(0.01354)\end{array}$ & & $\begin{array}{c}+0.0000111 \\
(0.0000063)\end{array}$ & $\begin{array}{r}+0.8193 \\
(0.1830)\end{array}$ & $\begin{array}{r}*+0.00447 \\
(0.02873)\end{array}$ & $\begin{array}{c}-0.14922 \\
(0.10943)\end{array}$ & $\begin{array}{r}+2.455 \\
(1.636)\end{array}$ & 0.02301 \\
\hline & $\begin{array}{c}+0.07881 \\
(0.01600)\end{array}$ & $\begin{array}{r}+0.08667 \\
(0.01291)\end{array}$ & $\begin{array}{c}+0.08868 \\
(0.02933)\end{array}$ & & $\begin{array}{r}+0.06275 \\
(0.01950)\end{array}$ & & & & & & 0.03171 \\
\hline $\begin{array}{c}+0.003919 \\
(0.002478)\end{array}$ & $\begin{array}{r}+0.08770 \\
(0.01516)\end{array}$ & $\begin{array}{c}+0.07347 \\
(0.01453)\end{array}$ & $\begin{array}{c}+0.09543 \\
(0.02920)\end{array}$ & & $\begin{array}{r}+0.07393 \\
(0.01881)\end{array}$ & $\begin{array}{r}+0.0000094 \\
(0.0000062)\end{array}$ & $\begin{array}{c}+0.3441 \\
(0.0935)\end{array}$ & $\begin{array}{r}+0.04897 \\
(0.02138)\end{array}$ & $\begin{array}{r}+0.10668 \\
(0.08722)\end{array}$ & $\begin{array}{r}+2.934 \\
(1.452)\end{array}$ & 0.02940 \\
\hline $\begin{array}{c}*+0.002059 \\
(0.003967)\end{array}$ & $\begin{array}{c}+0.08159 \\
(0.02951)\end{array}$ & $\begin{array}{r}+0.09010 \\
(0.02346)\end{array}$ & $\begin{array}{r}+0.09186 \\
(0.03802)\end{array}$ & & $\begin{array}{r}+0.08284 \\
(0.02437)\end{array}$ & $\begin{array}{r}* 0.0000110 \\
(0.0000113)\end{array}$ & $\begin{array}{c}+0.2521 \\
(0.1219)\end{array}$ & $\begin{array}{c}+0.08061 \\
(0.03074)\end{array}$ & $\begin{array}{r}*+0.06314 \\
(0.13602)\end{array}$ & ${ }^{*}+\underset{(2.386}{2.166}$ & $\begin{array}{r}0.03292 \\
-\end{array}$ \\
\hline $\begin{array}{c}+0.007472 \\
(0.003026)\end{array}$ & $\begin{array}{r}+0.08648 \\
(0.01512)\end{array}$ & $\begin{array}{c}+0.04950 \\
(0.01697)\end{array}$ & $*+\begin{array}{r}0.01441 \\
(0.05792)\end{array}$ & & $\begin{array}{r}*+0.01200 \\
(0.03714)\end{array}$ & $\begin{array}{r}+0.0000095 \\
(0.0000069)\end{array}$ & $\begin{array}{c}+0.8444 \\
(0.1859)\end{array}$ & $\begin{array}{r}*+0.00241 \\
(0.02916)\end{array}$ & $\begin{array}{r}-0.14377 \\
(0.11173)\end{array}$ & $\begin{array}{r}+2.482 \\
(1.670)\end{array}$ & $\begin{array}{r}0.02332 \\
-\end{array}$ \\
\hline
\end{tabular}


TABLE 9-12. Calculated contributions of independent variables to the percentage shrinkage at 28 days (the first 24 hr in moistair-storage) of neat-cement bars of normal consistency

\begin{tabular}{|c|c|c|c|c|}
\hline $\begin{array}{l}\text { Inde- } \\
\text { pendent } \\
\text { variable }\end{array}$ & $\begin{array}{l}\text { Ranges of } \\
\text { variables, } \\
\text { percent }\end{array}$ & $\begin{array}{l}\text { Coefficients } \\
\text { from eq } 3 \\
\text { table } 9-11\end{array}$ & $\begin{array}{l}\text { Calculated contri- } \\
\text { butions to } \mathrm{SH} 28\end{array}$ & $\begin{array}{c}\text { Calculat- } \\
\text { ed ranges } \\
\text { of contri- } \\
\text { butions to } \\
\text { SH } 28\end{array}$ \\
\hline 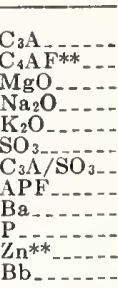 & $\begin{array}{c}0 \text { to } 15 \\
4 \text { to } 17 \\
0 \text { to } 5 \\
0 \text { to } 0.75 \\
0 \text { to } 1.1 \\
1.2 \text { to } 3.6 \\
0.4 \text { to } 10.1 \\
* 2500 \text { to } 5500 \\
0 \text { to } 0.2 \\
0 \text { to } 0.5 \\
0 \text { to } 0.2 \\
0 \text { to } 0.01\end{array}$ & $\begin{array}{l}-0.0204 \\
-0.00217 \\
+0.00539 \\
+0.0920 \\
+0.0779 \\
+0.0788 \\
+0.0368 \\
+0.0000133 \\
+0.319 \\
+0.0489 \\
+0.0964 \\
+3.021\end{array}$ & $\begin{array}{r}\text { Const. }=-0.023 \\
0 \text { to }-0.306 \\
-0.009 \text { to }-0.037 \\
0 \text { to }+0.027 \\
0 \text { to }+0.069 \\
0 \text { to }+0.086 \\
+0.095 \text { to }+0.283 \\
+0.015 \text { to }+0.372 \\
+0.033 \text { to }+0.073 \\
0 \text { to }+0.064 \\
0 \text { to }+0.024 \\
0 \text { to }-0.019 \\
0 \text { to }+0.030\end{array}$ & $\begin{array}{l}0.306 \\
0.028 \\
0.027 \\
0.069 \\
0.086 \\
0.188 \\
0.357 \\
0.040 \\
0.064 \\
0.024 \\
0.019 \\
0.030\end{array}$ \\
\hline
\end{tabular}

$* \mathrm{~cm}^{2} / \mathrm{g}$.

**Coefficient of doubtful significance as coef./s.d. ratio was less than 2.
$\mathrm{Ba}, \mathrm{Rb}$, and $\mathrm{Ni}$ in eqs 2 and 4 , a further significant reduction was obtained. The coef./s.d. ratio for $\mathrm{Rb}$, however, was less than 2 . Equations calculated for the "odds" and "evens" in the array of cements (eqs 2A, 2B, $4 \mathrm{~A}$ and $4 \mathrm{~B}$ ) indicated that $\mathrm{C}_{3} \mathrm{~A}, \mathrm{C}_{3} \mathrm{~S}, \mathrm{MgO}, \mathrm{C}_{3} \mathrm{~A} / \mathrm{SO}_{3}, \mathrm{Al}_{2} \mathrm{O}_{3}$ / $\mathrm{SO}_{3}$, and $\mathrm{Rb}$ had coef./s.d. ratios less than 1 in one or more of the equations for the smaller groups.

A comparable series of equations for the NAE cements is presented in table 9-15. The coefficients of the different independent variables agreed fairly well with those of table 9-14 where the $\mathrm{AE}$ cements were included. The variables $\mathrm{C}_{3} \mathrm{~A}, \mathrm{C}_{3} \mathrm{~S}$, and $\mathrm{Rb}$ had coef./s.d. ratios of less than 1 in equation $2 \mathrm{~A}$ where the "odds" in the array of cements were used in the computations.

TABLE 9-13. Frequency distribution of cements with respect to percentage shrinkage of neat cements of normal consistency after 6 months drying in laboratory air after $24 \mathrm{hr}$ moist-air storage (SH6M)

\begin{tabular}{|c|c|c|c|c|c|c|c|c|c|c|c|c|c|}
\hline \multirow{3}{*}{ Type cement } & \multicolumn{12}{|c|}{ Percentage shrinkage } & \multirow{3}{*}{ Total } \\
\hline & $\begin{array}{c}0.16 \\
\text { to } \\
0.20\end{array}$ & $\begin{array}{c}0.20 \\
\text { to } \\
0.24\end{array}$ & $\begin{array}{c}0.24 \\
\text { to } \\
0.28\end{array}$ & $\begin{array}{c}0.28 \\
\text { to } \\
0.32\end{array}$ & $\begin{array}{c}0.32 \\
\text { to } \\
0.36\end{array}$ & $\begin{array}{l}0.36 \\
\text { to } \\
0.40\end{array}$ & $\begin{array}{c}0.40 \\
\text { to } \\
0.44\end{array}$ & $\begin{array}{c}0.44 \\
\text { to } \\
0.48\end{array}$ & $\begin{array}{c}0.48 \\
\text { to } \\
0.52\end{array}$ & $\begin{array}{c}0.52 \\
\text { to } \\
0.56\end{array}$ & $\begin{array}{c}0.56 \\
\text { to } \\
0.60\end{array}$ & $\begin{array}{l}0.60 \\
\text { and } \\
\text { over }\end{array}$ & \\
\hline & \multicolumn{12}{|c|}{ Number of cements } & \\
\hline 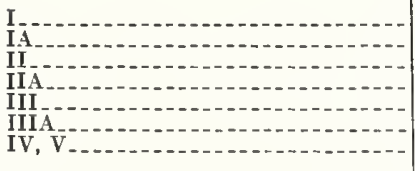 & 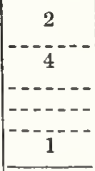 & $\frac{17}{17}$ & $\begin{array}{r}22 \\
4 \\
22 \\
1 \\
9 \\
1 \\
7\end{array}$ & $\begin{array}{r}14 \\
1 \\
5 \\
1 \\
5 \\
1 \\
2\end{array}$ & 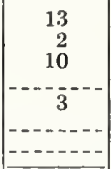 & 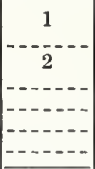 & 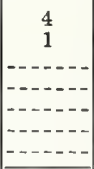 & 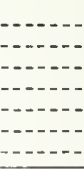 & 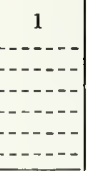 & 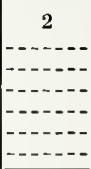 & 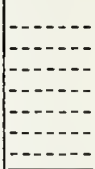 & 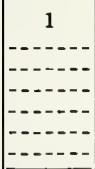 & $\begin{array}{r}77 \\
8 \\
60 \\
2 \\
19 \\
2 \\
14\end{array}$ \\
\hline Total & 7 & 40 & 66 & 29 & 28 & 3 & 5 & 0 & 1 & 2 & 0 & 1 & 182 \\
\hline
\end{tabular}

Coefficients of the independent variables in eq 2 of table 9-15 and their ranges were used to calculate their contributions and their possible ranges of contributions to the 6-monthskrinkage values of the neat cement bars for NAE cements. These are presented in table 9-16. The independent variables, $\mathrm{C}_{3} \mathrm{~A} / \mathrm{SO}_{3}$, $\mathrm{Na}_{2} \mathrm{O}, \mathrm{K}_{2} \mathrm{O}$, and $\mathrm{Ba}$, apparently resulted in the greatest calculated ranges of the contributions to the 6-month-shrinkage values.

\subsection{Time of Cracking of Annular Specimens Restrained from Shrinkage}

The frequency distributions of the time of cracking of the annular specimens made with the different portland cements, each using the water required for normal consistency, are presented in table 9-17. The specimens were stored in an atmosphere of 95 to 100 percent relative humidity for the first $24 \mathrm{hr}$. The time of cracking ranged from a few minutes to more than $40 \mathrm{hr}$ after removal from the molds. The Type I cements had a broad distribution of values with a large number cracking within a relatively short time. More than half of the specimens made with Type III cements also cracked within $2.5 \mathrm{hr}$. The median values of the Types II, IV, and V cements indicated that a longer time period was required for the annular specimens made with these cements to crack. There was, however, considerable overlapping of the distributions of the time of cracking of the cements of the different types.

Preliminary plots of the time of cracking of the annular specimens versus various individual independent variables are presented in figure 9-5. Absolute values of "quadrant sum" equal to or greater than 11 were obtained for $\mathrm{SiO}_{2}, \mathrm{Al}_{2} \mathrm{O}_{3}, \mathrm{Fe}_{2} \mathrm{O}_{3}, \mathrm{SO}_{3}, \mathrm{~K}_{2} \mathrm{O}$, total alkali, $\mathrm{C}_{3} \mathrm{~A}$, $\mathrm{C}_{2} \mathrm{~S}, \mathrm{C}_{4} \mathrm{AF}$, and $\mathrm{Al}_{2} \mathrm{O}_{3} / \mathrm{Fe}_{2} \mathrm{O}_{3}$.

An outstanding feature of the distribution of the time-of-cracking data is the large concentration at the early end of the scale. More than half of the breaks occurred in $10 \mathrm{hr}$ or less. Thus the distribution curve of the data is strongly skewed to the right, i.e., the "hump" of the curve is near the left end with a long "tail" stretching far out to the right. 


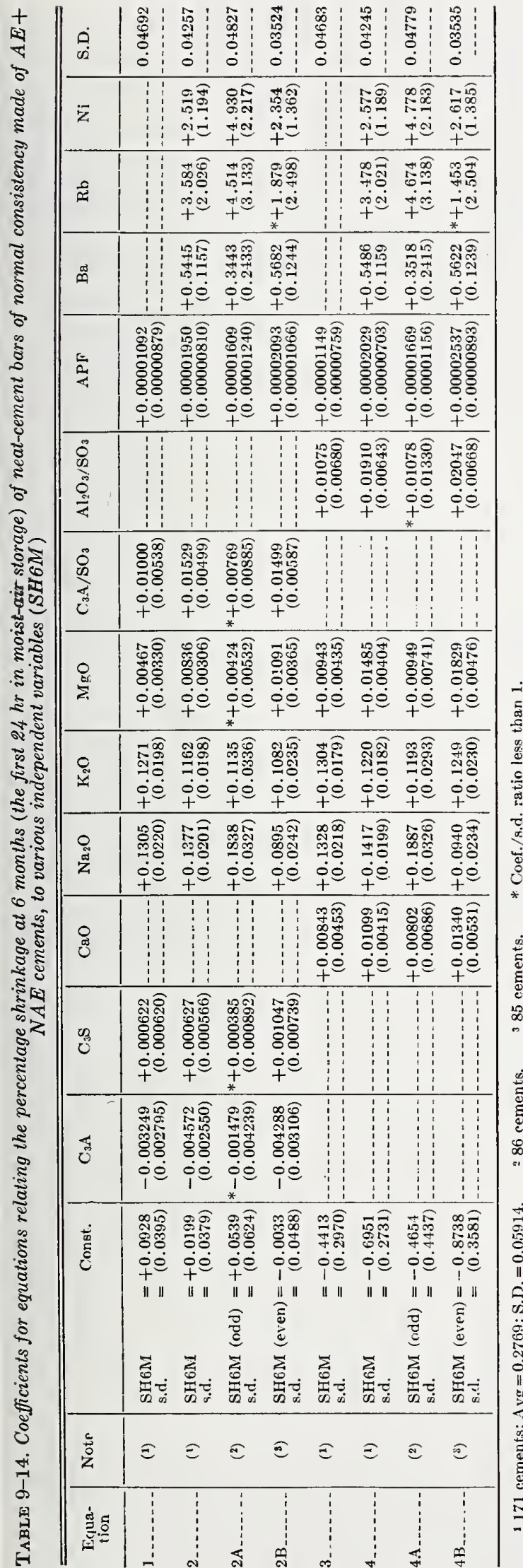

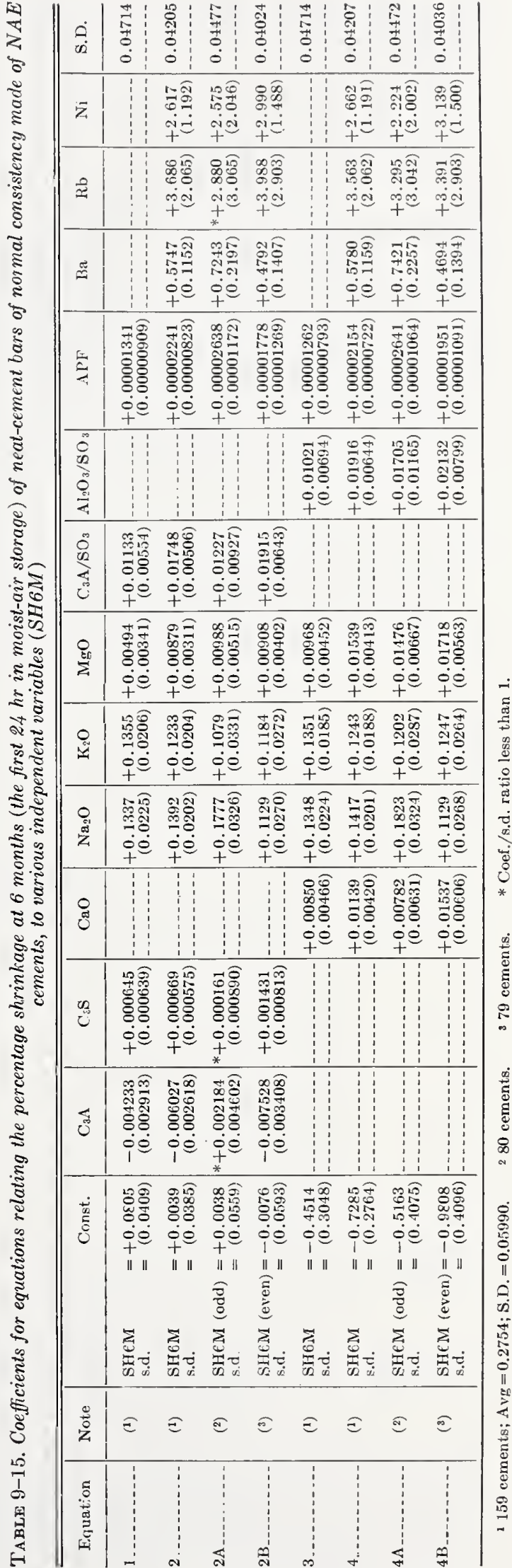


TABLE 9-16. Calculated contributions of independent variables to the percentage shrinkage at 6 months (the first $34 \mathrm{hr}$ in moist-air-storage) of neat-cement bars of normal consistency (SH6M)

\begin{tabular}{|c|c|c|c|c|}
\hline $\begin{array}{l}\text { Inde- } \\
\text { pendent } \\
\text { variable }\end{array}$ & $\begin{array}{l}\text { Ranges of } \\
\text { variables, } \\
\text { percent }\end{array}$ & $\begin{array}{l}\text { Coefficients } \\
\text { from eq } 2 \\
\text { table } 9-15\end{array}$ & $\begin{array}{l}\text { Calculated contri- } \\
\text { butions to SH28 }\end{array}$ & $\begin{array}{l}\text { Calculat- } \\
\text { ed ranges } \\
\text { of contri- } \\
\text { butions to } \\
\text { SH } 6 M\end{array}$ \\
\hline 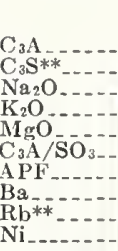 & $\begin{array}{c}0 \text { to } 15 \\
30 \text { to } 70 \\
0 \text { to } 0.75 \\
0 \text { to } 1.1 \\
0 \text { to } 5 \\
0.4 \text { to } 10.1 \\
\text { *2500 to } 5500 \\
0 \text { to } 0.2 \\
0 \text { to } 0.01 \\
0 \text { to } 0.02\end{array}$ & $\begin{array}{l}-0.00603 \\
+0.000669 \\
+0.139 \\
+0.123 \\
+0.00879 \\
+0.0175 \\
+0.0000224 \\
+0.575 \\
+3.686 \\
+2.617\end{array}$ & $\begin{array}{r}\text { Const. }=+0.004 \\
0 \text { to }-0.090 \\
+0.020 \text { to }+0.047 \\
0 \text { to }+0.104 \\
0 \text { to }+0.135 \\
0 \text { to }+0.044 \\
+0.007 \text { to }+0.177 \\
+0.056 \text { to }+0.123 \\
0 \text { to }+0.115 \\
0 \text { to }+0.037 \\
0 \text { to }+0.052\end{array}$ & $\begin{array}{l}0.090 \\
0.027 \\
0.104 \\
0.135 \\
0.044 \\
0.170 \\
0.067 \\
0.115 \\
0.037 \\
0.052\end{array}$ \\
\hline
\end{tabular}

$* \mathrm{~cm}^{2} / \mathrm{g}$.

* Coefficient of doubtful significance as coef./\$.d. ratio was less than 2 .
The multivariate analysis used throughout this series of articles is based on the assumption that the underlying distribution curve of the data is the familiar bell-shaped normal curve, with the hump in the middle and approximately symmetrical tails stretching out on both sides. In cases where both the data themselves and logical considerations related to the underlying phenomenon indicate that this is not the case, some other way of evaluating the relationships involved must be found if the results are to be meaningful.

Frequently, when data are not normally distributed, the log or square root or some other transformation of the original data fits the normal distribution more closely and can be handled with the usual statistical techniques

TABLE 9-17. Frequency distribution of the cements with respect to the time required for the annular specimens of neat cement to crack $(T O B R)$

\begin{tabular}{|c|c|c|c|c|c|c|c|c|c|c|c|c|c|c|}
\hline \multirow{3}{*}{ Type cement } & \multicolumn{13}{|c|}{ Time of cracking, hours } & \multirow{3}{*}{ Total } \\
\hline & $\begin{array}{c}0 \\
\text { to } \\
2.5\end{array}$ & $\begin{array}{c}2.5 \\
\text { to } \\
5.0\end{array}$ & $\begin{array}{l}5.0 \\
\text { to } \\
7.5\end{array}$ & $\begin{array}{c}7.5 \\
\text { to } \\
10.0\end{array}$ & $\begin{array}{c}10.0 \\
\text { to } \\
12.5\end{array}$ & $\begin{array}{c}12.5 \\
\text { to } \\
15.0\end{array}$ & $\begin{array}{c}15.0 \\
\text { to } \\
17.5\end{array}$ & $\begin{array}{c}17.5 \\
\text { to } \\
20.0\end{array}$ & $\begin{array}{c}20.0 \\
\text { to } \\
22.5\end{array}$ & $\begin{array}{c}22.5 \\
\text { to } \\
25.0\end{array}$ & $\begin{array}{c}25.0 \\
\text { to } \\
27.5\end{array}$ & $\begin{array}{c}27.5 \\
\text { to } \\
30.0\end{array}$ & $\begin{array}{l}30.0 \\
\text { and } \\
\text { over }\end{array}$ & \\
\hline & \multicolumn{13}{|c|}{ Number of cements } & \\
\hline $\mathrm{I}_{-}$ & $\begin{array}{r}19 \\
3\end{array}$ & $\begin{array}{r}12 \\
1\end{array}$ & 8 & $\begin{array}{l}6 \\
1\end{array}$ & $\begin{array}{l}8 \\
3\end{array}$ & $\mathrm{e}$ & 3 & 4 & 3 & 1 & $\begin{array}{c}2 \\
-\end{array}$ & 1 & $\begin{array}{r}1 \\
-\end{array}$ & $\begin{array}{r}77 \\
8\end{array}$ \\
\hline II - & 1 & $\frac{1}{7}$ & $-\overline{7}$ & $\begin{array}{l}1 \\
9 \\
1\end{array}$ & 7 & $-\overline{5}$ & 14 & 4 & 2 & 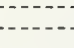 & i & 2 & ( n l & 59 \\
\hline III & 10 & 1 & 4 & 1 & $\overline{2}$ & 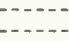 & & 1 & 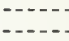 & 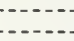 & - & (n) & 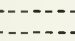 & $\begin{array}{r}2 \\
19\end{array}$ \\
\hline IIIIA, II $_{-\ldots}$ & 2 & & 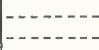 & $\overline{1}$ & 3 & $-\overline{3}$ & $-\overline{2}$ & $-2-$ &.- & 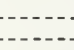 & 1 & (n) & 2 & $\begin{array}{r}2 \\
14\end{array}$ \\
\hline Total & 35 & 21 & 19 & 19 & 23 & 17 & 20 & 11 & 5 & 1 & 4 & 3 & 3 & 181 \\
\hline
\end{tabular}

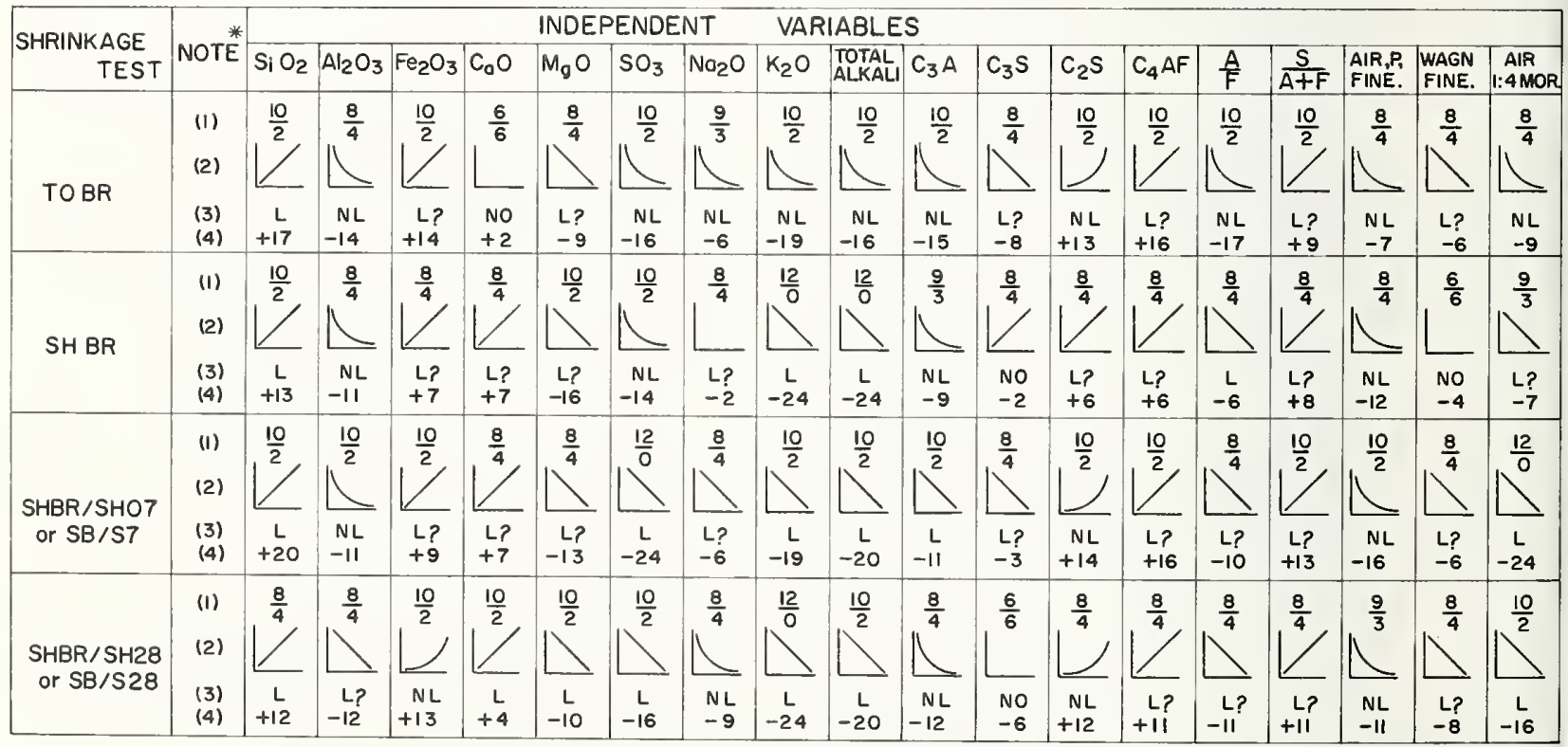

FIGURE 9-5. Results of plotting (1) the time of cracking of the annular specimens, (2) the percentage shrinkage of prisms at the time of cracking of the annular specimens, and (3) (4) the ratios of the percentage nonrestrained shrinkage at the time of cracking of the annular specimens to the nonrestrained shrinkage at 7 and 28 days, respectively, on the " $\mathrm{Y}$ " axis versus various independent variables on the "X" axis.

* Note (1) Ratio of number of plotted points in pairs of diametrically opposite quadrants.

Note (2) General trend of lines drawn through plotted points.

Note (3) Apparent nature of relationship. $\mathrm{L}=$ linear; $\mathrm{NL}=$ nonlinear; $\mathrm{NO}=$ no apparent relationship; and $\mathrm{L}$ ? $=$ nature of rela-

Note (4) Quadrant sum in corner test (see reference 5). 
[18]. Of several different functions of the time-of-break-data tried, the square root gave the best approximation to a normal distribution. Table 9-18 gives the frequency distribution of the square root of the time-of-breakdata by types.

TABLE 9-18. Frequency distribution of cements with respect to the square root of the time required for the annular specimens of neat cement to crack $(T O B R)^{0.5}$

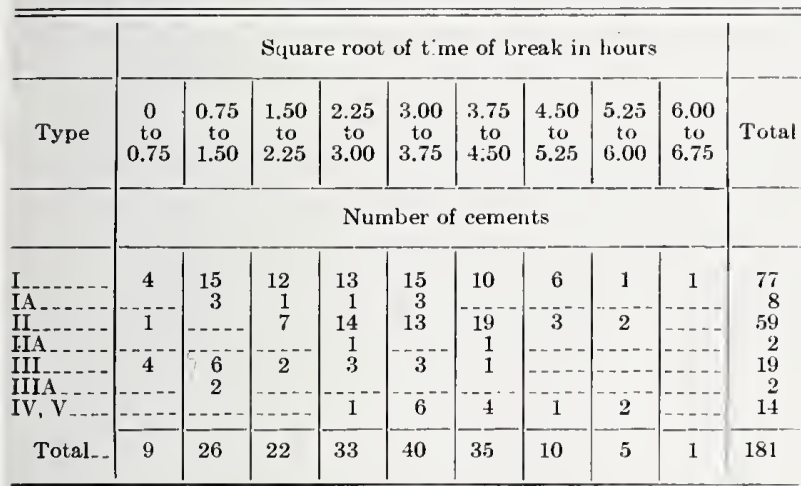

Selected equations relating various independent variables with the square root of time of break are given in table 9-19 for $\mathrm{AE}+\mathrm{NAE}$ cements and in table 9-20 for NAE cements alone. ${ }^{10}$ Equation 1 of table 9-19 indicates that specimens made with cements with the higher water requirements for normal consistency $\left(W_{1}\right)$ had a tendency to crack earlier than those with lower water requirements. The relationship of commonly determined variables to the time of break is presented in eq 2. The S.D. value was reduced very significantly (see table 9-34). With the addition of the independent variables $\mathrm{MgO}, \mathrm{Ba}, \mathrm{Rb}$, and $\mathrm{Zr}$ in eq 3 a further significant reduction in variance was attained. In the equations for the "odds" and "evens", $\mathrm{SO}_{3}$ in eq $3 \mathrm{~A}$ and $\mathrm{Rb}$ and $\mathrm{Zr}$ in eq $3 \mathrm{~B}$ had coef./ s.d. ratios less than 1 . The use of the oxides $\mathrm{SiO}_{2}$ and $\mathrm{Fe}_{2} \mathrm{O}_{3}$ in eqs 4 and 5 resulted in S.D. values almost identical with those attained in eqs 2 and 3 when the calculated compounds $\mathrm{C}_{3} \mathrm{~S}$ and $\mathrm{C}_{4} \mathrm{AF}$ were used.

\footnotetext{
10 Since the analysis of this subsection is based on the square root of the time-of-break-data, the various statistical quantities calculated such as coefficients, standard deviations, etc., cannot be used directly as quantitative measures of significance associated with the original untransformed data. However, since the square root transformation is order-preserving", relative magnitudes and trends of these measures may be used to support the general remarks about relationship given here. It is interesting that, although the coefficients and standard deviations were changed by the transformation of the data, coef/s.d. ratios were almost the same for the square root as for the untransformed data.
}

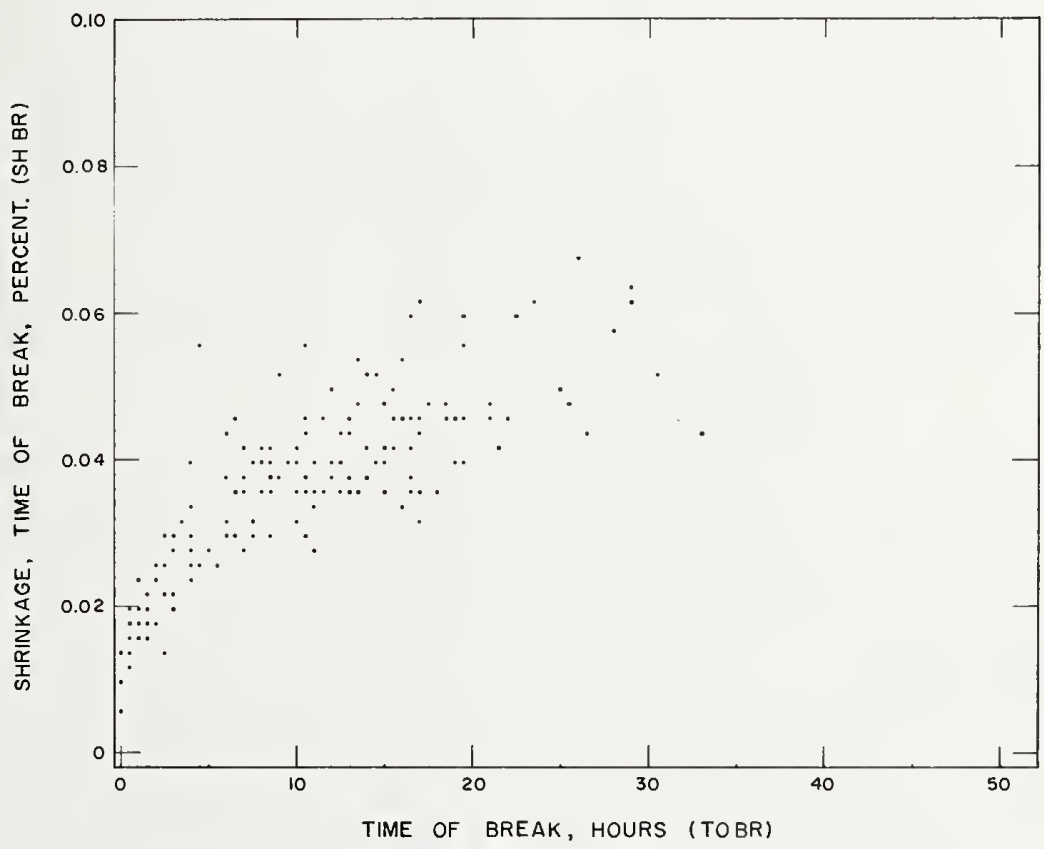

FIGURE 9-6. Results of plotting the percentage shrinkage of the nonrestrained bars at the time of cracking of the annular specimens versus the time of cracking of the annular specimens.

(Both types of specimens were made of neat portland cement pastes of normal consistency and cured for 24 hours in moist air prior to exposure to laboratory air.)

Corresponding equations for the NAE cements are presented in table 9-20. The coefficients for the different independent variables and the coef./s.d. ratios were in reasonable agreement with those of table 9-19 where the $\mathrm{AE}$ cements were included.

Coefficients of the variables in eq 3 of table 9-20 were used with their ranges to calculate 


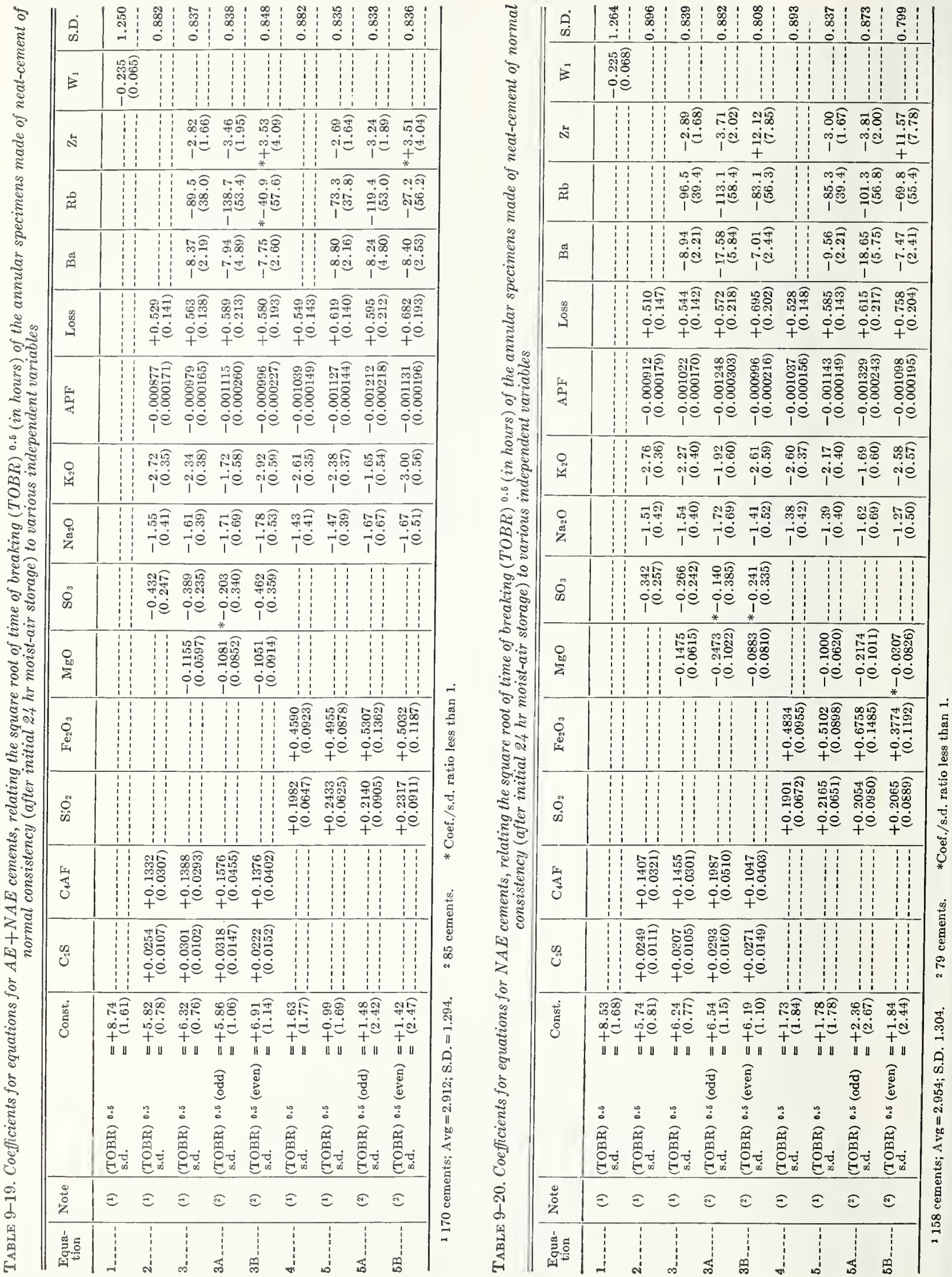


their contributions to the time of breaking of the annular specimens as well as the ranges of these contributions. The results of these calculations are presented in table 9-21. Differences in fineness and $\mathrm{K}_{2} \mathrm{O}$ appear to have the greatest effect on the time of breaking with restrained shrinkage. Increases in fineness, $\mathrm{K}_{2} \mathrm{O}, \mathrm{Na}_{2} \mathrm{O}$, $\mathrm{Ba}$, and possibly $\mathrm{MgO}, \mathrm{SO}_{3}, \mathrm{Zr}$, and $\mathrm{Rb}$ appear associated with a decrease in the time of breaking. Increases in loss on ignition and $\mathrm{C}_{4} \mathrm{AF}$ appear associated with an increase in the time of breaking.

TABLE 9-21. Calculated contributions to the time of breaking (TOBR) ${ }^{0.5}$ of the annular specimens (after initial $24 \mathrm{hr}$ moistair-storage) of neat-cement of normal consistency

\begin{tabular}{|c|c|c|c|c|}
\hline $\begin{array}{l}\text { Inde- } \\
\text { pendent } \\
\text { variable }\end{array}$ & $\begin{array}{l}\text { Ranges of } \\
\text { variables, } \\
\text { percent }\end{array}$ & $\begin{array}{l}\text { Coefficients } \\
\text { from eq } 3 \\
\text { table } 9-20\end{array}$ & 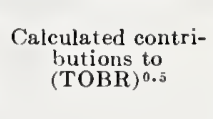 & $\begin{array}{l}\text { Calculat- } \\
\text { ed ranges } \\
\text { of contri- } \\
\text { butions to } \\
(\mathrm{TOBR})^{0.5}\end{array}$ \\
\hline 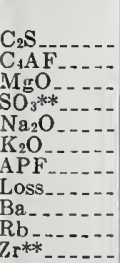 & 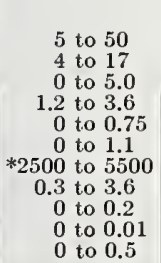 & $\begin{array}{l}+0.0307 \\
+0.1455 \\
-0.1475 \\
-0.266 \\
-1.54 \\
-2.27 \\
-0.001022 \\
+0.544 \\
-8.94 \\
-96.5 \\
-2.89\end{array}$ & $\begin{array}{r}\text { Const. }=+6.24 \\
+0.15 \text { to }+1.54 \\
+0.58 \text { to }+2.47 \\
0 \text { to }-0.74 \\
-0.32 \text { to }-0.96 \\
0 \text { to }-1.15 \\
0 \text { to }-2.50 \\
-2.55 \text { to }-5.62 \\
+0.16 \text { to }+1.96 \\
0 \text { to }-1.79 \\
0 \text { to }-0.96 \\
0 \text { to }-1.44\end{array}$ & $\begin{array}{l}1.39 \\
1.89 \\
0.73 \\
0.64 \\
1.15 \\
2.50 \\
3.07 \\
1.80 \\
1.79 \\
0.96 \\
1.44\end{array}$ \\
\hline
\end{tabular}

$* \mathrm{~cm}^{2} / \mathrm{g}$.

**Coefficient of doubtful significance as coef./s.d. ratio was less than 2 .
5.6. Nonrestrained Shrinkage of Prisms at Time of Cracking of Annular Specimens

A plot of the percent shrinkage of the nonrestrained bars at the time of cracking of the annular specimens versus the time of cracking of the annular specimens restrained from shrinkage is presented in figure 9-6. Some of the annular specimens cracked at a time when the nonrestrained specimens had shrunk very little. With other cements, the neat pastes were apparently more capable of adjusting to the stresses, or the shrinkage occurred at a slower rate, and a longer period of time was required to crack the specimens restrained from shrinkage. No measurements were made of the loss of weight of the specimens with time of exposure to the laboratory air.

The frequency distributions (for the different types of cements) of the percentage shrinkage of the nonrestrained bars at the time of cracking of the restrained annular specimens are presented in table 9-22 ${ }^{11}$. The range of the percentage-shrinkage values was quite broad for each of the different types of cements as classified, and there was an overlapping of the values for the cements within the different types.

11 Since these data appear to have a reasonably normal distribution, they are analyzed in the usual way.

TABLE 9-22. Frequency distribution of cements with respect to percentage shrinkage of neat cement bars at the time of breaking of the annular specimens (SHBR)

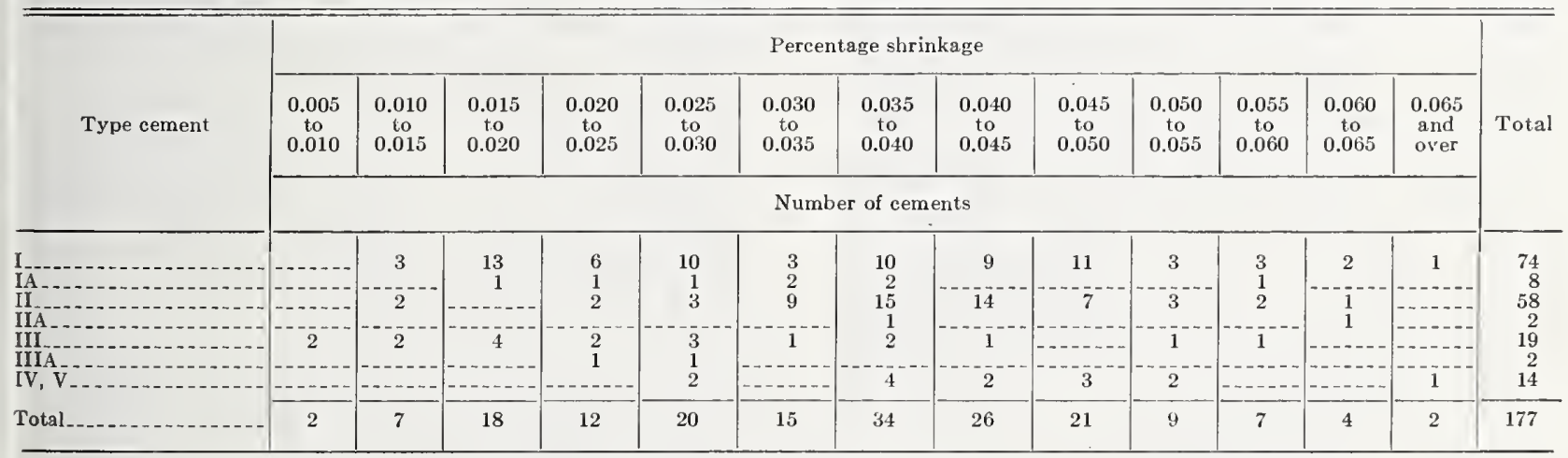

The results of the preliminary plots of the nonrestrained shrinkage of the bars at the time of cracking of the annular specimens which were restrained versus the various individual independent variables are presented in figure 9-5. The absolute value of the quadrant sum was 11 or greater for $\mathrm{SiO}_{2}, \mathrm{Al}_{2} \mathrm{O}_{3}, \mathrm{MgO}, \mathrm{SO}_{3}$, $\mathrm{K}_{2} \mathrm{O}$, total alkali, and fineness. Comparing the signs of the quadrant sums as well as the general trend of the lines drawn through the plotted points with those obtained for the shrinkage at $24 \mathrm{hr}$ (SH24) in the top group of figures in figure 9-4, it may be noted that, where comparable, the slopes and signs were different for practically every one of the variables.

Equations relating various independent variables to the nonrestrained shrinkage of the neat cement bars at the time of cracking of the annular specimens for $\mathrm{AE}+\mathrm{NAE}$ cements are presented in table 9-23. The relationship to the percentage water required for normal consistency, $W_{1}$, in eq 1 was not highly significant. With the use of commonly determined variables in eqs 2 or 4 there was a highly significant reduction in the S.D. value (see table 9-34). The use of the trace elements $\mathrm{Rb}, \mathrm{Ti}, \mathrm{Cu}$, and $\mathrm{V}$ in eq 3 or $\mathrm{Rb}, \mathrm{Cu}$, and $\mathrm{V}$ in eq 5 resulted in a reduction of the S.D. value significant at the 5- 


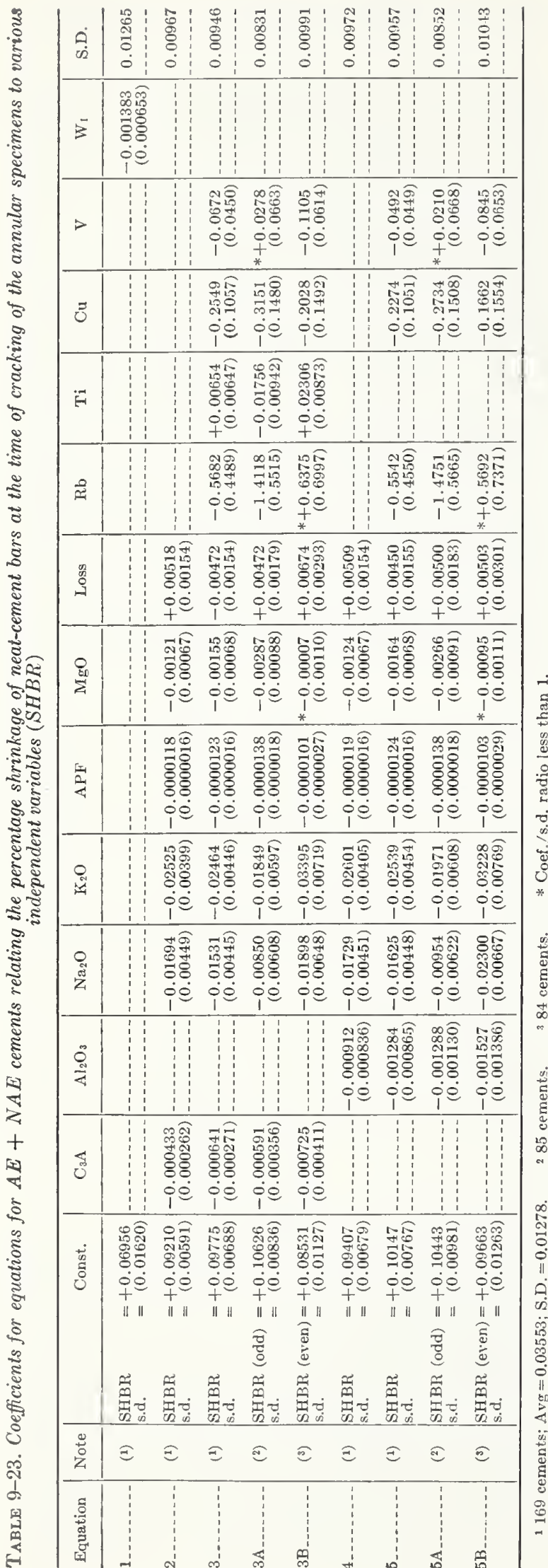

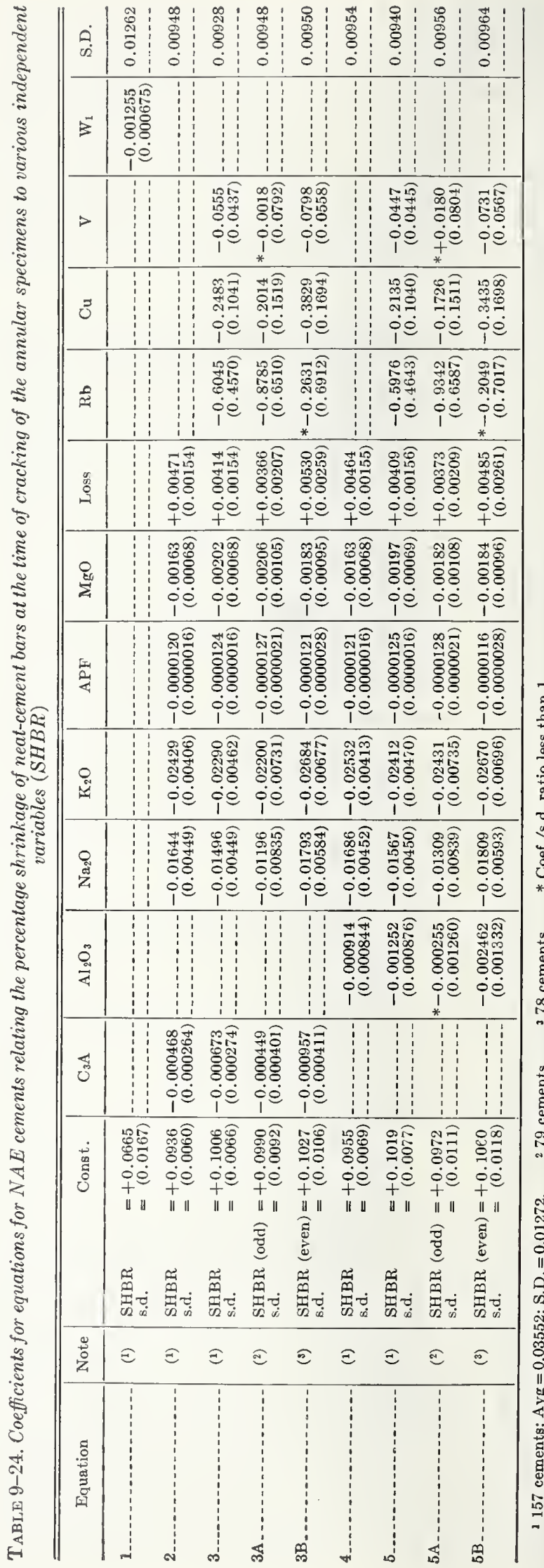


percent probability level. In the equations for the "odds" and "evens" (eqs 3A, 3B, 5A, and $5 \mathrm{~B}$ ) the coef./s.d. ratios of $\mathrm{MgO}, \mathrm{Rb}$, and $\mathrm{V}$ were less than 1 in one or the other of the equations for the smaller groups of cements, and the coefficient for $\mathrm{Ti}$ had a reversal of sign in eq $3 \mathrm{~B}$.

Corresponding equations for the NAE cements are presented in table 9-24. The coefficients and coef./s.d. ratios of the independent variables are generally in accord with those of the previous table where the $\mathrm{AE}$ cements were included. In table 9-24, the coef./s.d. ratio for Ti was less than 1 when included with the other variables in eq 3 . As in the previous table, the use of commonly determined variables in eqs 2 and 4 resulted in a highly significant reduction in the S.D. values. The additional use of the trace elements in eqs 3 and 5 did not result in highly significant reductions in the S.D. values (see table 9-34). The equations for the "odds" and "evens" (eqs 3A, 3B, 5A and 5B) indicated that the coef./s.d. ratios of $\mathrm{Al}_{2} \mathrm{O}_{3}, \mathrm{Rb}$, and $\mathrm{V}$ were less than 1 in one or the other of the pairs of equations for the smaller groups of cement.

Using the values for the coefficients of the independent variables in eq 3 of table 9-24 and the ranges of these variables, calculations were

TABLE 9-25. Calculated contributions to the percentage shrinkage of neat-cement bars at the time of cracking of the annular specimens ( $S H B R$ )

\begin{tabular}{|c|c|c|c|c|}
\hline $\begin{array}{l}\text { Inde- } \\
\text { pendent } \\
\text { variable }\end{array}$ & $\begin{array}{l}\text { Ranges of } \\
\text { variables, } \\
\text { percent }\end{array}$ & $\begin{array}{l}\text { Coefficients } \\
\text { from eq } 3 \\
\text { table } 9-24\end{array}$ & $\begin{array}{l}\text { Calculated contri- } \\
\text { butions to SHBR }\end{array}$ & $\begin{array}{c}\text { Calculat- } \\
\text { ed ranges } \\
\text { of contri- } \\
\text { butions to } \\
\text { SHBR }\end{array}$ \\
\hline $\begin{array}{l}\mathrm{C}_{3} \mathrm{~A}_{-}- \\
\mathrm{Na}_{2} \mathrm{O}_{-} \\
\mathrm{K}_{2} \mathrm{O}_{--} \\
\mathrm{APF}- \\
\mathrm{MgO}- \\
\mathrm{Loss}_{-} \\
\mathrm{Rb}^{* *} \\
\mathrm{Cu}_{-} \\
\mathrm{V} * *\end{array}$ & $\begin{array}{c}0 \text { to } 15 \\
0 \text { to } 0.75 \\
0 \text { to } 1.1 \\
\text { *2500 to } 5500 \\
0 \text { to } 5.0 \\
0.3 \text { to } 3.6 \\
0 \text { to } 0.01 \\
0 \text { to } 0.05 \\
0 \text { to } 0.1\end{array}$ & $\begin{array}{l}-0.000673 \\
-0.01496 \\
-0.0229 \\
-0.0000124 \\
-0.00202 \\
+0.00414 \\
-0.6045 \\
-0.2483 \\
-0.0555\end{array}$ & $\begin{array}{r}\text { Const. }=+0.101 \\
0 \text { to }-0.010 \\
0 \text { to }-0.011 \\
0 \text { to }-0.025 \\
-0.025 \text { to }-0.068 \\
0 \text { to }-0.010 \\
+0.001 \text { to }+0.015 \\
0 \text { to }-0.060 \\
0 \text { to }=0.012 \\
0 \text { to }-0.006\end{array}$ & $\begin{array}{l}0.010 \\
0.011 \\
0.025 \\
0.043 \\
0.010 \\
0.014 \\
0.060 \\
0.012 \\
0.006\end{array}$ \\
\hline
\end{tabular}

${ }^{*} \mathrm{~cm}^{2} / \mathrm{g}$.
$* *$ Coelficient of doubtful significance as coef./s.d. ratio was less than 2. made of their possible contributions to SHBR and the ranges of their contributions. These calculated values are presented in table 9-25. Differences in fineness and $\mathrm{K}_{2} \mathrm{O}$ appear to have the greatest effect on the nonrestrained shrinkage of the bars at the time of breaking of the restrained annular specimens. Increases in $\mathrm{Na}_{2} \mathrm{O}, \mathrm{C}_{3} \mathrm{~A}, \mathrm{MgO}$ and $\mathrm{Cu}$ may also be associated with lower values for SHBR but increases in the loss on ignition with higher values.

\subsection{Ratio of Nonrestrained Shrinkage at Time of Gracking of Annular Specimens to the Nonrestrained Shrinkage at 7 Days, (SB/S7)}

The frequency distributions of the different types of cements with respect to the ratios of the nonrestrained percentage-shrinkage values (SHBR/SHO7) or $\mathrm{SB} / \mathrm{S} 7$ are presented in table 9-26. The shrinkage ratios varied over a wide range,-from 0.02 to over 0.54 -indicating that the annular specimens of some cements cracked when very little shrinkage had occurred in the bars, and others only after considerably more shrinkage had occurred. This difference is, however, further complicated by the fact that the rate of shrinkage was not the same for all cement pastes as was noted in figure 9-7.

The results of plotting $\mathrm{SB} / \mathrm{S} 7$ versus the various independent variables are presented in Fig. 9-5. The variables $\mathrm{SiO}_{2}, \mathrm{Al}_{2} \mathrm{O}_{3}, \mathrm{MgO}, \mathrm{SO}_{3}$, $\mathrm{K}_{2} \mathrm{O}$, total alkali, $\mathrm{C}_{3} \mathrm{~A}, \mathrm{C}_{2} \mathrm{~S}, \mathrm{C}_{4} \mathrm{AF}, \mathrm{S} /(\mathrm{A}+\mathrm{F})$, air permeability fineness and (air, 1:4 mortar) all had absolute values of 11 or more for the "quadrant-sum."

Selected equations are presented in table 9-27 to indicate the relationships of the combinations of independent variables to the ratios of the nonrestrained shrinkage at the time of cracking of the annular specimens divided by the nonrestrained shrinkage at 7 days for the $\mathrm{AE}+\mathrm{NAE}$ cements. The relationship in eq 1 indicates that the shrinkage ratios are probably lower with higher water-requirements for normal consistency. Table 9-34 indicates that the

TABLE 9-26. Frequency distribution of the cements with respect to the ratio of the shrinkage of the neat cement bars at the time of crack ing of the annular specimens to their shrinkage at $\gamma$ days (SHBR/SHOY or $S B / S \gamma)$

\begin{tabular}{|c|c|c|c|c|c|c|c|c|c|c|c|c|c|c|c|}
\hline \multirow{3}{*}{ Type cement } & \multicolumn{14}{|c|}{ Shrinkage ratio } & \multirow{3}{*}{ Total } \\
\hline & $\begin{array}{c}0.02 \\
\text { to } \\
0.06\end{array}$ & $\begin{array}{c}0.06 \\
\text { to } \\
0.10\end{array}$ & $\begin{array}{c}0.10 \\
\text { to } \\
0.14\end{array}$ & $\begin{array}{c}0.14 \\
\text { to } \\
0.18\end{array}$ & $\begin{array}{c}0.18 \\
\text { to } \\
0.22\end{array}$ & $\begin{array}{c}0.22 \\
\text { to } \\
0.26\end{array}$ & $\begin{array}{c}0.26 \\
\text { to } \\
0.30\end{array}$ & $\begin{array}{c}0.30 \\
\text { to } \\
0.34\end{array}$ & $\begin{array}{c}0.34 \\
\text { to } \\
0.38\end{array}$ & $\begin{array}{c}0.38 \\
\text { to } \\
0.42\end{array}$ & $\begin{array}{c}0.42 \\
\text { to } \\
0.46\end{array}$ & $\begin{array}{c}0.46 \\
\text { to } \\
0.50\end{array}$ & $\begin{array}{c}0.50 \\
\text { to } \\
0.54\end{array}$ & $\begin{array}{l}0.54 \\
\text { and } \\
\text { over }\end{array}$ & \\
\hline & \multicolumn{14}{|c|}{ Number of cements } & \\
\hline & 1 & $\begin{array}{r}10 \\
1 \\
2\end{array}$ & $\begin{array}{r}10 \\
2\end{array}$ & $\begin{array}{l}8 \\
1 \\
7\end{array}$ & $\begin{array}{l}8 \\
1 \\
4\end{array}$ & $\begin{array}{l}5 \\
2 \\
9\end{array}$ & $\begin{array}{l}10 \\
-10\end{array}$ & $\begin{array}{c}7 \\
-12\end{array}$ & $\begin{array}{l}4 \\
1 \\
8\end{array}$ & 2 & 2 & 1 & 4 & 1 & $\begin{array}{r}73 \\
8 \\
58\end{array}$ \\
\hline & 2 & 4 & 4 & -- & $\begin{array}{l}1 \\
1\end{array}$ & 3 & 1 & 1 & 0 & $\begin{array}{l}0 \\
1\end{array}$ & (n) & & & 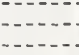 & $\begin{array}{r}2 \\
19\end{array}$ \\
\hline $\begin{array}{l}\text { IIIA } \\
\text { lv, }\end{array}$ & & & 1 & 1 & 2 & 2 & 2 & 2 & 2 & 1 & -1 & 2 & $\overline{1}$ & & $\begin{array}{r}2 \\
14\end{array}$ \\
\hline Total _. - - & 3 & 17 & 17 & 19 & 17 & 21 & 23 & 22 & 15 & 8 & 5 & 3 & 5 & 1 & 176 \\
\hline
\end{tabular}




\begin{tabular}{|c|c|c|c|c|c|c|c|}
\hline Equation & Note & & Const. & $\mathrm{C}_{2} \mathrm{~S}$ & $\mathrm{C}_{4} \mathrm{AF}$ & $\mathrm{CaO}$ & $\mathrm{Fe}_{2} \mathrm{O}_{3}$ \\
\hline 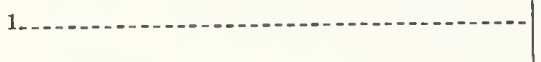 & (1) & $\begin{array}{l}\text { SB/S7 } \\
\text { s.d. }\end{array}$ & $\begin{array}{l}=+0.6197 \\
=(0.1418)\end{array}$ & 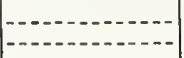 & --- & & \\
\hline 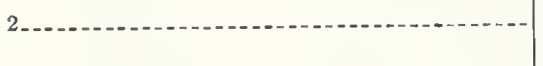 & (1) & $\begin{array}{l}\text { SB/S7 } \\
\text { s.d. }\end{array}$ & $\begin{array}{l}=+0.6546 \\
=(0.0687)\end{array}$ & $\begin{array}{r}*+0.000803 \\
(0.000923)\end{array}$ & $\begin{array}{r}+0.00578 \\
(0.00276)\end{array}$ & & \\
\hline 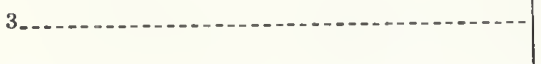 & (1) & $\begin{array}{l}\text { SB/S7 } \\
\text { s.d. }\end{array}$ & $\begin{array}{l}=+0.6754 \\
=(0.0666)\end{array}$ & $\begin{array}{r}+0.001293 \\
(0.000916)\end{array}$ & $\begin{array}{r}+0.00843 \\
(0.00276)\end{array}$ & & \\
\hline $3 A_{-1}$ & $\left({ }^{2}\right)$ & $\begin{array}{l}\text { SB/S7 (odd) } \\
\text { s.d. }\end{array}$ & $\begin{array}{l}=+0.7251 \\
=(0.0931)\end{array}$ & $\begin{array}{r}*+0.001006 \\
(0.001243)\end{array}$ & $\begin{array}{c}+0.00676 \\
(0.00401)\end{array}$ & & \\
\hline 3B. & $\left({ }^{3}\right)$ & $\begin{array}{l}\text { SB/S7 (even) } \\
\text { s.d. }\end{array}$ & $\begin{array}{l}=+0.6727 \\
=\quad(0.1056)\end{array}$ & $\begin{array}{r}*+0.001121 \\
(0.001445)\end{array}$ & $\begin{array}{c}+0.00844 \\
(0.00413)\end{array}$ & & \\
\hline 4_- & (1) & $\begin{array}{l}\text { SB/S7 } \\
\text { s.d. }\end{array}$ & $\begin{array}{l}=+1.827 \\
=(0.679)\end{array}$ & 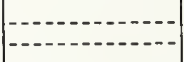 & 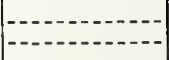 & $\begin{array}{c}-0.01645 \\
(0.00985)\end{array}$ & $\begin{array}{r}*+0.00657 \\
(0.01072)\end{array}$ \\
\hline 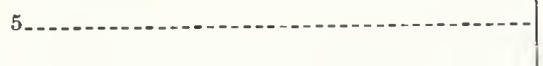 & (1) & $\begin{array}{l}\text { SB/S7 } \\
\text { s.d. }\end{array}$ & $\begin{array}{l}=+1.980 \\
=(0.655)\end{array}$ & & 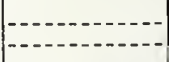 & $\begin{array}{c}-0.01819 \\
(0.00950)\end{array}$ & $\begin{array}{r}+0.01433 \\
(0.01055)\end{array}$ \\
\hline 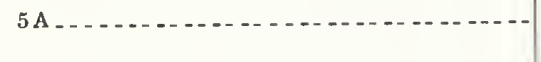 & $\left({ }^{2}\right)$ & $\begin{array}{l}\text { SB/S7 (odd) } \\
\text { s.d. }\end{array}$ & $\begin{array}{l}=+1.797 \\
=(0.884)\end{array}$ & 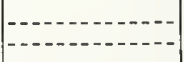 & '-- & $\begin{array}{c}-0.01512 \\
(0.01287)\end{array}$ & $\begin{array}{r}*+0.01079 \\
(0.01504)\end{array}$ \\
\hline 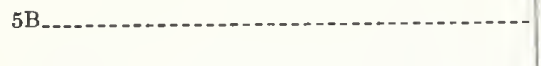 & $\left({ }^{3}\right)$ & $\begin{array}{l}\text { SB/S7 (even) } \\
\text { s.d. }\end{array}$ & $\begin{array}{l}=+1.893 \\
=(1.036)\end{array}$ & 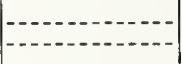 & $\mid-1-1-1-1-1$ & $\begin{array}{c}-0.01707 \\
(0.01500)\end{array}$ & $*+\underset{(0.01568)}{0.01526}$ \\
\hline
\end{tabular}

1167 cements; $\mathrm{Avg}=0.2514$; S.D. $=0.1125 . \quad 284$ cements. $\quad \& 83$ cements. $\quad$ * Coef./s.d. ratio less than 1.

relationship was significant at the 5-percent probability level.

The use of commonly determined variables in eq 2 resulted in a highly significant reduction in the S.D. value. $\mathrm{C}_{2} \mathrm{~S}$ was included although the coef./s.d. ratio was less than 1 in eq 2 but greater than 1 in eq 3 . With the additional use of the trace elements, $\mathrm{Rb}, \mathrm{V}, \mathrm{Ni}$, and $\mathrm{Cu}$ in eq 3 , a further significant reduction in the S.D. value was obtained although none of the coefficients of any of the individual trace elements was by itself highly significant. The coef./s.d. ratio of $\mathrm{C}_{2} \mathrm{~S}, \mathrm{Rb}, \mathrm{V}$, and $\mathrm{Cu}$ was less than 1 in eqs $3 \mathrm{~A}$ or $3 \mathrm{~B}$, or both when the smaller groups of cements were used in computing the equations.

The use of the oxides in eq 4 instead of the potential compounds also resulted in a significant reduction in the S.D. value (see table
9-34). With the addition of the trace elements in eq 5 a further significant reduction was obtained. In the equations for the "odds" and "evens" (eqs 5A and 5B) the coef./s.d. ratios of $\mathrm{Fe}_{2} \mathrm{O}_{3}, \mathrm{SO}_{3}, \mathrm{Rb}$, and $\mathrm{Cu}$ were less than 1 in one or both of the equations for the smaller groups of cements and the sign of the coefficient for $\mathrm{V}$ was reversed in eq $5 \mathrm{~A}$.

A corresponding series of relationships computed for the NAE cements is presented in table 9-28. Equation 1 indicates the relationship of the shrinkage ratios to the water requirements for normal consistency of the neat cement pastes. Equations 2 and 4 present the relationships of commonly determined variables and eqs 3 and 5 the commonly determined variables with the addition of trace elements. In eq $5, \mathrm{SO}_{3}$ was also used. A highly significant 
age of neat-cement bars at the time of cracking for the annular specimens to the shrinkage $S B / S 7$, to various independent variables

\begin{tabular}{|c|c|c|c|c|c|c|c|c|c|c|}
\hline $\mathrm{SO}_{3}$ & $\mathrm{MgO}$ & $\mathrm{Na}_{2} \mathrm{O}$ & $\mathrm{K}_{2} \mathrm{O}$ & APF & $\mathrm{Rb}$ & V & $\mathrm{Ni}$ & $\mathrm{Cu}$ & $W_{1}$ & S.D. \\
\hline & & & & & & & & & $\begin{array}{c}-0.01488 \\
(0.00572)\end{array}$ & 0.1100 \\
\hline & $\begin{array}{c}-0.01571 \\
(0.00546)\end{array}$ & $\begin{array}{c}-0.1745 \\
(0.0371)\end{array}$ & $\begin{array}{r}-0.2560 \\
(0.0307)\end{array}$ & $\begin{array}{c}-0.0000821 \\
(0.0000127)\end{array}$ & & & & & & 0.0783 \\
\hline & $\begin{array}{c}-0.01965 \\
(0.00536)\end{array}$ & $\begin{array}{c}-0.1653 \\
(0.0362)\end{array}$ & $\begin{array}{c}-0.2533 \\
(0.0348)\end{array}$ & $\begin{array}{c}-0.0000872 \\
(0.0000123)\end{array}$ & $\begin{array}{c}-5.748 \\
(3.667)\end{array}$ & $\begin{array}{c}-0.5124 \\
(0.3763)\end{array}$ & $\begin{array}{c}-3.663 \\
(2.176)\end{array}$ & $\begin{array}{c}-1.798 \\
(0.853)\end{array}$ & & 0.0752 \\
\hline & $\begin{array}{c}-0.02217 \\
(0.00764)\end{array}$ & $\begin{array}{c}-0.1523 \\
(0.0457)\end{array}$ & $\begin{array}{c}-0.2436 \\
(0.0502)\end{array}$ & $\begin{array}{c}-0.0000946 \\
(0.0000165)\end{array}$ & $\begin{array}{c}-10.406 \\
(5.003)\end{array}$ & $\begin{array}{r}*+0.6035 \\
(0.6778)\end{array}$ & $\begin{array}{c}-5.118 \\
(3.322)\end{array}$ & $\begin{array}{l}-2.040 \\
(1.237)\end{array}$ & & 0.0731 \\
\hline$\ldots$ & $\begin{array}{c}-0.02032 \\
(0.00832)\end{array}$ & $\begin{array}{c}-0.2346 \\
(0.0652)\end{array}$ & $\begin{array}{c}-0.2644 \\
(0.0537)\end{array}$ & $\begin{array}{c}-0.0000802 \\
(0.0000196)\end{array}$ & $*+0.899$ & $\begin{array}{c}-1.0049 \\
(0.4935)\end{array}$ & $\begin{array}{r}-5.515 \\
(3.260)\end{array}$ & $\begin{array}{r}*-0.765 \\
(1.354)\end{array}$ & & 0.0782 \\
\hline $\begin{array}{c}-0.0367 \\
(0.0228)\end{array}$ & $\begin{array}{c}-0.02672 \\
(0.00860)\end{array}$ & $\begin{array}{r}-0.1869 \\
(0.0381)\end{array}$ & $\begin{array}{c}-0.2563 \\
(0.0340)\end{array}$ & $\begin{array}{r}-0.0000739 \\
(0.0000142)\end{array}$ & $2-2-2-2-3$ & & & 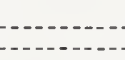 & & 0.0778 \\
\hline $\begin{array}{c}-0.0331 \\
(0.0222)\end{array}$ & $\begin{array}{c}-0.03135 \\
(0.00838)\end{array}$ & $\begin{array}{c}-0.1773 \\
(0.0372)\end{array}$ & $\begin{array}{l}-0.2607 \\
(0.0379)\end{array}$ & $\begin{array}{r}-0.0000822 \\
(0.0000141)\end{array}$ & $\begin{array}{r}-5.715 \\
(3.651)\end{array}$ & $\begin{array}{c}-0.3812 \\
(0.3634)\end{array}$ & $\begin{array}{c}-3.772 \\
(2.175)\end{array}$ & $\begin{array}{r}-1.819 \\
(0.851)\end{array}$ & & 0.0749 \\
\hline $\begin{array}{c}*+0.0127 \\
(0.0320)\end{array}$ & $\begin{array}{c}-0.03253 \\
(0.01216)\end{array}$ & $\begin{array}{c}-0.1632 \\
(0.0475)\end{array}$ & $\begin{array}{c}-0.2508 \\
(0.0539)\end{array}$ & $\begin{array}{r}-0.0000945 \\
(0.0000187)\end{array}$ & $\begin{array}{r}-10.687 \\
(5.025)\end{array}$ & $\begin{array}{c}+0.6916 \\
(0.6646)\end{array}$ & $\begin{array}{c}-5.248 \\
(3.362)\end{array}$ & $\begin{array}{c}-1.890 \\
(1.239)\end{array}$ & & 0.0732 \\
\hline $\begin{array}{c}-0.0408 \\
(0.0328)\end{array}$ & $\begin{array}{c}-0.03044 \\
(0.01250)\end{array}$ & $\begin{array}{c}-0.2425 \\
(0.0665)\end{array}$ & $\begin{array}{c}-0.2724 \\
(0.0590)\end{array}$ & $\begin{array}{c}-0.0000703 \\
(0.0000230)\end{array}$ & $\begin{array}{r}*+1.013 \\
(5.551)\end{array}$ & $\begin{array}{c}-0.8362 \\
(0.4853)\end{array}$ & $\begin{array}{c}-5.295 \\
(3.248)\end{array}$ & $\begin{array}{c}*-0.941 \\
(1.358)\end{array}$ & & 0.0780 \\
\hline
\end{tabular}

reduction in the S.D. values was attained by using the additional independent variables in the equations (see table 9-34). It may be noted in tables 9-27 and 9-28 that the coefficients for $\mathrm{Na}_{2} \mathrm{O}, \mathrm{K}_{2} \mathrm{O}$, fineness, and $\mathrm{MgO}$ were all highly significant. An increase in each of these independent variables appeared associated with lower SB/S7 ratios.

The coefficients of the independent variables in eq 3 table 9-28 were used together with their approximate ranges of values to calculate their contributions to the $\mathrm{SB} / \mathrm{S} 7$ ratio and the ranges of these contributions. These values are presented in table 9-29. Differences in fineness and $\mathrm{K}_{2} \mathrm{O}$ were associated to the greatest extent with differences in the $\mathrm{SB} / \mathrm{S} 7$ ratios. Differences in $\mathrm{Na}_{2} \mathrm{O}, \mathrm{MgO}, \mathrm{C}_{4} \mathrm{AF}$, and $\mathrm{Cu}$ may also be associated with differences in the SB/S7 ratios.
5.8. Ratio of Nonrestrained Shrinkage of Bars at Time of Cracking of The Annular Specimens to the Nonrestrained Shrinkage of the Bars at 28 Days, (SHBR/SH28) or (SB/S28)

The frequency distributions of the shrinkage-ratio values (SB/S28) of the different types of cements are presented in table 9-30. A fairly broad distribution of the shrinkageratio values was obtained with each of the types of cement as classified. There was also an overlapping of the values in the different types. However, the median value of the Type III cements was lowest. The median value of the Type I cements was slightly higher, and the Types II, IV and V had still higher median values.

The results of the preliminary plots of SB/ $\mathrm{S} 28$ versus various individual independent vari- 


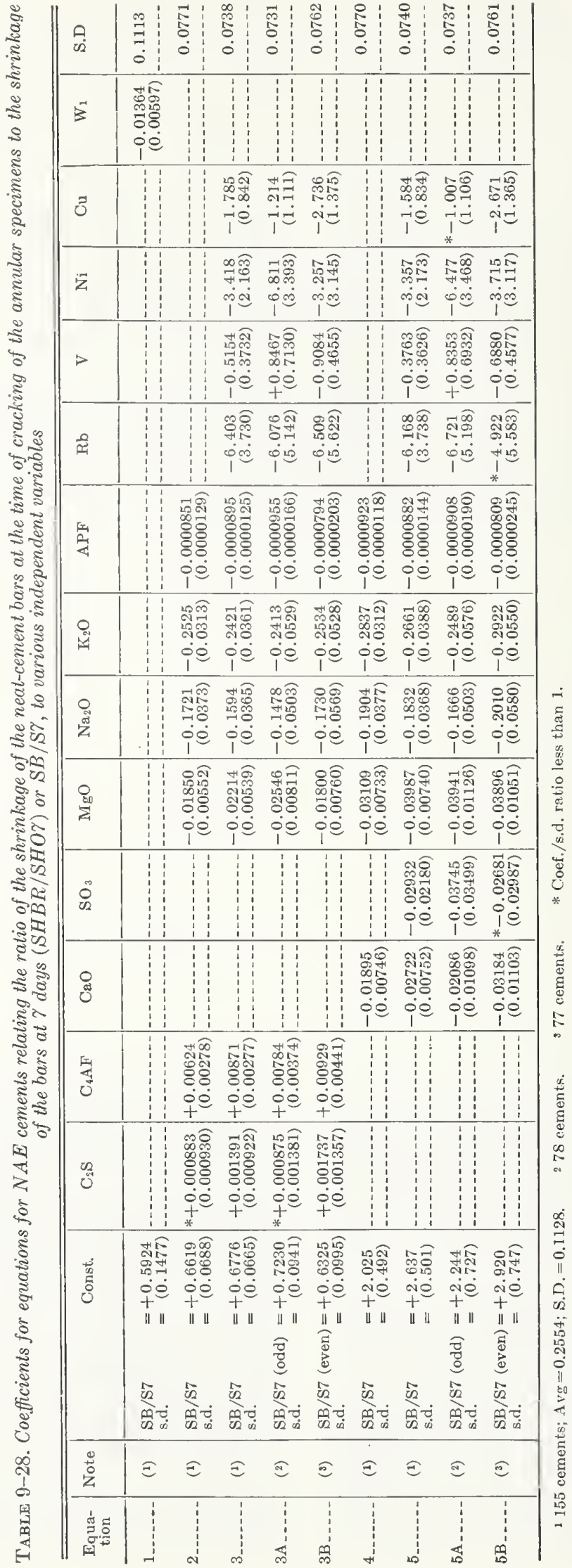


TABLE 9-29. Calculated contributions to the ratio of the shrinkage of the neat-cement bars at the time of cracking of the annular specimens to their shrinkage at 7 days, SHBR/SHOF or $S B / S \gamma$

\begin{tabular}{|c|c|c|c|c|}
\hline $\begin{array}{l}\text { Inde- } \\
\text { pendent } \\
\text { variable }\end{array}$ & $\begin{array}{l}\text { Ranges of } \\
\text { variables, } \\
\text { percent }\end{array}$ & $\begin{array}{c}\text { Coefficients } \\
\text { from eq } 3 \\
\text { table } 9-28\end{array}$ & $\begin{array}{l}\text { Calculated contri- } \\
\text { butions to } \mathrm{SB} / \mathrm{S} 7\end{array}$ & $\begin{array}{l}\text { Calculat- } \\
\text { ed ranges } \\
\text { of contri- } \\
\text { butions to } \\
\text { SR/S7 }\end{array}$ \\
\hline 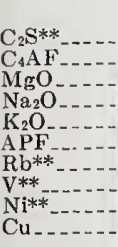 & $\begin{array}{c}5 \text { to } 50 \\
4 \text { to } 17 \\
0 \text { to } 5 \\
0 \text { to } 0.75 \\
0 \text { to } 1.1 \\
* 2500 \text { to } 5500 \\
0 \text { to } 0.01 \\
0 \text { to } 0.1 \\
0 \text { to } 0.02 \\
0 \text { to } 0.05\end{array}$ & $\begin{array}{l}+0.001391 \\
+0.00871 \\
-0.02214 \\
-0.1594 \\
-0.2421 \\
-0.0000895 \\
-6.403 \\
-0.5154 \\
-3.418 \\
-1.785\end{array}$ & $\begin{array}{r}\text { Const. }=+0.678 \\
+0.007 \text { to }+0.069 \\
+0.035 \text { to }+0.148 \\
0 \text { to }-0.111 \\
0 \text { to }-0.120 \\
0 \text { to }-0.266 \\
-0.224 \text { to }-0.492 \\
0 \text { to }-0.064 \\
0 \text { to }-0.052 \\
0 \text { to }-0.068 \\
0 \text { to }-0.089\end{array}$ & $\begin{array}{l}0.062 \\
0.113 \\
0.111 \\
0.120 \\
0.266 \\
0.268 \\
0.064 \\
0.052 \\
0.068 \\
0.089\end{array}$ \\
\hline
\end{tabular}

$* \mathrm{~cm}^{2} / \mathrm{g}$.
$* *$ Coefficient of doubtful significance as coef./s.d. ratio was less than 2. ables are presented in figure 9-5. "Quadrant sums" with absolute values of 11 or more were obtained for the independent variables $\mathrm{SiO}_{2}$, $\mathrm{Al}_{2} \mathrm{O}_{3}, \mathrm{Fe}_{2} \mathrm{O}_{3}, \mathrm{SO}, \mathrm{K}_{2} \mathrm{O}, \mathrm{C}_{3} \mathrm{~A}, \mathrm{C}_{2} \mathrm{~S}, \mathrm{C}_{4} \mathrm{AF}, \mathrm{A} / \mathrm{F}$, $\mathrm{S} /(\mathrm{A}+\mathrm{F}), \mathrm{APF}$, and (air, 1: 4 mortar).

Selected equations indicating the relationship of various independent variables to the ratio of the nonrestrained shrinkage of the bars at the time of cracking of the annular specimens to the nonrestrained shrinkage of the bars at 28 days are presented in table 9-31 for the $\mathrm{AE}+\mathrm{NAE}$ cements. The use of the percentage water required for normal consistency in eq 1 did not result in a highly significant reduction in the S.D. value (see table 9-34). Using commonly determined variables found to have coef./s.d. ratios greater than 1 in eqs 2 and 4 , highly significant reductions in the S.D. values

ТАВLE 9-30. Frequency distribution of the cements with respect to the ratio of the shrinkage of neat cement bars at the time of cracking of the annular specimens to their shrinkage at 28 days (SHBR/SH28 or SB/S28)

\begin{tabular}{|c|c|c|c|c|c|c|c|c|c|c|c|c|c|c|}
\hline \multirow{3}{*}{ Type cement } & \multicolumn{13}{|c|}{ Shrinkage ratio } & \multirow{3}{*}{ Total } \\
\hline & $\begin{array}{c}0.02 \\
\text { to } \\
0.06\end{array}$ & $\begin{array}{c}0.06 \\
\text { to } \\
0.10\end{array}$ & $\begin{array}{c}0.10 \\
\text { to } \\
0.14\end{array}$ & $\begin{array}{c}0.14 \\
\text { to } \\
0.18\end{array}$ & $\begin{array}{c}0.18 \\
\text { to } \\
0.22\end{array}$ & $\begin{array}{c}0.22 \\
\text { to } \\
0.26\end{array}$ & $\begin{array}{c}0.26 \\
\text { to } \\
0.30\end{array}$ & $\begin{array}{c}0.30 \\
\text { to } \\
0.34\end{array}$ & $\begin{array}{c}0.34 \\
\text { to } \\
0.38\end{array}$ & $\begin{array}{c}0.38 \\
\text { to } \\
0.42\end{array}$ & $\begin{array}{c}0.42 \\
\text { to } \\
0.46\end{array}$ & $\begin{array}{c}0.46 \\
\text { to } \\
0.50\end{array}$ & $\begin{array}{l}0.50 \\
\text { and } \\
\text { over }\end{array}$ & \\
\hline & \multicolumn{13}{|c|}{ Number of cements } & \\
\hline \multirow{4}{*}{ 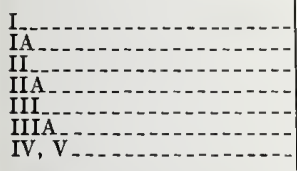 } & 8 & \multirow{4}{*}{$\begin{array}{r}15 \\
3 \\
3 \\
-5 \\
1 \\
-\end{array}$} & \multirow{4}{*}{$\begin{array}{r}11 \\
1 \\
7 \\
-3 \\
1 \\
2\end{array}$} & \multirow{4}{*}{$\begin{array}{r}12 \\
3 \\
13 \\
1 \\
3 \\
-3\end{array}$} & 11 & \multirow{2}{*}{$\begin{array}{l}8 \\
1 \\
7\end{array}$} & 1 & 5 & 1 & & - & - & 1 & $\begin{array}{r}73 \\
8\end{array}$ \\
\hline & 1 & & & & 22 & & 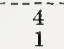 & 1 & $\cdots$ & & 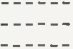 & (n) & & $\begin{array}{r}58 \\
2\end{array}$ \\
\hline & 5 & & & & 2 & 1 & & & & & - & $-\alpha$ & & $\begin{array}{r}19 \\
2\end{array}$ \\
\hline & 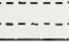 & & & & 2 & 3 & 2 & 2 & - & n & (n) & (n) & 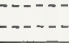 & 14 \\
\hline Total_. & 14 & 27 & 25 & 35 & 37 & 20 & 8 & 8 & 1 & 0 & 0 & 0 & 1 & 176 \\
\hline
\end{tabular}

were obtained, and with the additional use of the trace elements $\mathrm{Rb}, \mathrm{Ni}, \mathrm{V}$, and $\mathrm{Cu}$ in eqs 3 and 5 , further significant reductions in the S.D. values were obtained. In the equations for the "odds" and "evens" (eqs $3 \mathrm{~A}, 3 \mathrm{~B}, 5 \mathrm{~A}$, and $5 B)$ all of the trace elements as well as $\mathrm{C}_{2} \mathrm{~S}$ had coef./s.d. ratios less than 1 in one or the other of the equations calculated with the smaller groups of cements.

A similar series of equations is presented in table 9-32 for the NAE cements. The use of commonly determined variables in eq 2 resulted in a highly significant reduction in the S.D. value, and the addition of the trace elements $\mathrm{Rb}, \mathrm{Ni}, \mathrm{V}$, and $\mathrm{Cu}$ resulted in a further significant reduction in the S.D. value (see table $9-34)$. Comparing eqs 4 and 5 it may be noted that the coef./s.d. ratio for $\mathrm{CaO}$ was less than 1 when $\mathrm{MgO}$ was not used as an independent variable in equation 4 but was greater than 3 in eq 4 when $\mathrm{MgO}$ was used. The use of commonly determined variables in eqs 4 or 5 resulted in highly significant reductions in the
S.D. values and the additional use of the trace elements in eq 6 resulted in a further significant reduction in the S.D. value. The eqs calculated for the "odds" and "evens" in the array of cements (eqs 3A, 3B, 6A, and 6B) indicated that $\mathrm{C}_{2} \mathrm{~S}, \mathrm{Rb}, \mathrm{Ni}$, and $\mathrm{Cu}$ had coef./s.d. ratios less than 1 in one or the other of the pairs of equations, and that the coefficient for $\mathrm{V}$ had a change of sign in eqs $3 \mathrm{~A}$ and $6 \mathrm{~A}$.

In tables 9-31 and 9-32 the coefficients for fineness, $\mathrm{K}_{2} \mathrm{O}$, and $\mathrm{Na}_{2} \mathrm{O}$ were the most highly significant and an increase in these variables was associated with a decrease in the SB/S28 ratio.

Using the coefficients of eq 3 of table 9-32 and the approximate ranges of values, calculations were made of the contributions and ranges of contributions of the various independent variables. The results of these calculations are presented in table 9-33. Fineness values and $\mathrm{K}_{2} \mathrm{O}$ content of the cements had the greatest calculated ranges of contributions to the $\mathrm{SB} / \mathrm{S} 28$ ratios. 


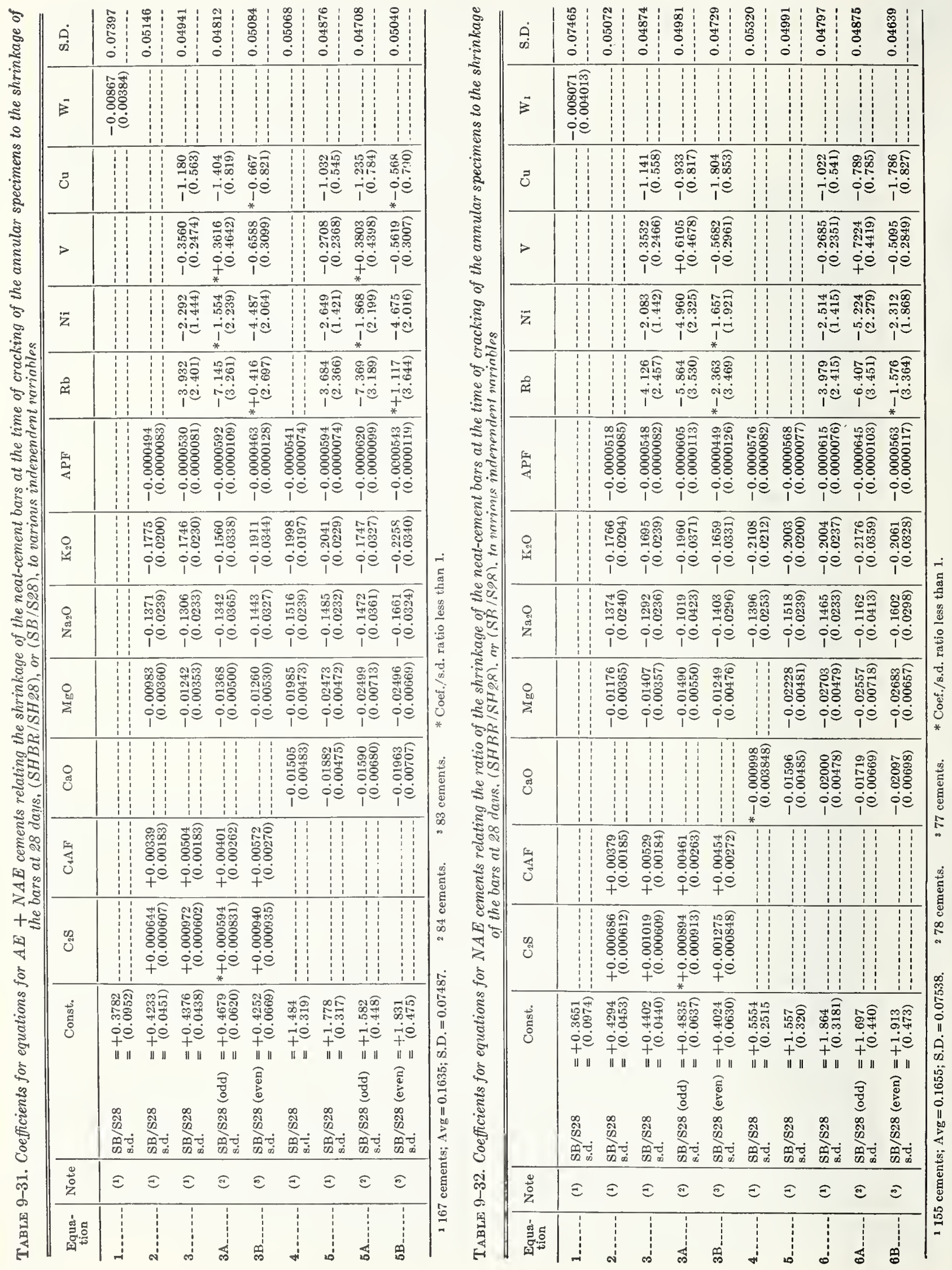


TABLE 9-33. Calculated contributions to the ratio of the shrinkage of the neat-cement bars att the time of cracking of the annular specimens to their shrinkage at 28 days, SHBR/SH28 or $S B / S 28$

\begin{tabular}{|c|c|c|c|c|}
\hline $\begin{array}{l}\text { Inde- } \\
\text { pendent } \\
\text { variable }\end{array}$ & $\begin{array}{l}\text { Ranges of } \\
\text { variables, } \\
\text { percent }\end{array}$ & $\begin{array}{l}\text { Coefficients } \\
\text { from eq. } 3 \\
\text { table } 9-32\end{array}$ & $\begin{array}{l}\text { Calculated contri- } \\
\text { butions to SB/S28 }\end{array}$ & $\begin{array}{l}\text { Calculat- } \\
\text { ed ranges } \\
\text { of contri- } \\
\text { butions to } \\
\text { SB/S28 }\end{array}$ \\
\hline $\begin{array}{l}\mathrm{C}_{2} \mathrm{~S}_{* *} \\
\mathrm{C}_{4} \mathrm{AF} \\
\mathrm{MgO}- \\
\mathrm{Na}_{2} \mathrm{O}= \\
\mathrm{K}_{2} \mathrm{O} \\
\mathrm{APF} \\
\mathrm{Rb}^{* *} \\
\mathrm{Ni*} \\
\mathrm{V} * * \\
\mathrm{Cu}\end{array}$ & $\begin{array}{l}5 \text { to } 50 \\
4 \text { to } 17 \\
0 \text { to } 5 \\
0 \text { to } 0.75 \\
0 \text { to } 1.1 \\
* 2500 \text { to } 5500 \\
0 \text { to } 0.01 \\
0 \text { to } 0.02 \\
0 \text { to } 0.1 \\
0 \text { to } 0.05\end{array}$ & $\begin{array}{l}+0.001019 \\
+0.00529 \\
-0.01407 \\
-0.1292 \\
-0.1695 \\
-0.0000548 \\
-4.126 \\
-2.083 \\
-0.3532 \\
-1.141\end{array}$ & $\begin{array}{r}\text { Const. }=+0.440 \\
+0.005 \text { to }+0.051 \\
+0.021 \text { to }+0.090 \\
0 \text { to }-0.070 \\
0 \text { to }-0.097 \\
0 \text { to }-0.186 \\
-0.137 \text { to }-0.301 \\
0 \text { to }-0.041 \\
0 \text { to }-0.042 \\
0 \text { to }-0.035 \\
0 \text { to }-0.057\end{array}$ & $\begin{array}{l}0.046 \\
0.069 \\
0.070 \\
0.097 \\
0.186 \\
0.164 \\
0.041 \\
0.042 \\
0.035 \\
0.057\end{array}$ \\
\hline
\end{tabular}

${ }^{*}{ }^{*} \mathrm{~cm}^{2} / \mathrm{g}$. Coefficient of doubtful significance as coef./s.d. ratio was less than 2.

ТABLE 9-34. " $F$ " values for significance of reduction of variance due to added variables

\begin{tabular}{|c|c|c|c|c|c|}
\hline \multirow{2}{*}{ Table } & \multirow{2}{*}{ Equations* } & \multirow{2}{*}{$\begin{array}{l}\text { "F"" } \\
\text { ratio }\end{array}$} & \multirow{2}{*}{ D.F. } & \multicolumn{2}{|c|}{ Critical " $F$ " Ratio } \\
\hline & & & & $\alpha=0.01$ & $\alpha=0.05$ \\
\hline $9-2 \ldots \ldots-\cdots$ & $\begin{array}{l}0,1 \\
0,2 \\
2,3 \\
0,4 \\
4,5\end{array}$ & $\begin{array}{r}10.20 \\
17.84 \\
3.30 \\
17.27 \\
3.12\end{array}$ & $\begin{array}{l}2: 161 \\
7: 156 \\
5: 151 \\
8: 155 \\
4: 151\end{array}$ & $\begin{array}{l}4.74 \\
2.75 \\
3.14 \\
2.62 \\
3.44\end{array}$ & $\begin{array}{l}3.05 \\
2.07 \\
2.27 \\
2.00 \\
2.44\end{array}$ \\
\hline $9-3 \ldots \ldots-\ldots$ & $\begin{array}{l}0,1 \\
0,2 \\
2,3 \\
0,4 \\
4,5\end{array}$ & $\begin{array}{r}7.59 \\
14.98 \\
3.54 \\
15.12 \\
3.85\end{array}$ & $\begin{array}{l}2: 149 \\
7: 144 \\
5: 139 \\
7: 144 \\
6: 138\end{array}$ & $\begin{array}{l}4.75 \\
2.77 \\
3.15 \\
2.77 \\
2.94\end{array}$ & $\begin{array}{l}3.05 \\
2.07 \\
2.27 \\
2.07 \\
2.16\end{array}$ \\
\hline $9-6 \ldots+----$ & $\begin{array}{l}0,1 \\
0,2 \\
2,3 \\
3,4 \\
0,5 \\
5,6 \\
6,7\end{array}$ & $\begin{array}{l}2.37 \\
5.91 \\
9.99 \\
5.00 \\
5.98 \\
7.45 \\
5.95\end{array}$ & $\begin{array}{l}2: 163 \\
4: 161 \\
4: 157 \\
3: 154 \\
5: 160 \\
5: 155 \\
3: 152\end{array}$ & $\begin{array}{l}4.74 \\
3.43 \\
3.43 \\
3.90 \\
3.13 \\
3.15 \\
3.90\end{array}$ & $\begin{array}{l}3.05 \\
2.44 \\
2.44 \\
2.68 \\
2.27 \\
2.27 \\
2.68\end{array}$ \\
\hline $9-7 \ldots \ldots$ & $\begin{array}{l}0,1 \\
0,2 \\
2,3 \\
3,4 \\
0,5 \\
5,6\end{array}$ & $\begin{array}{l}1.84 \\
4.41 \\
9.84 \\
4.69 \\
4.64 \\
7.39\end{array}$ & $\begin{array}{l}2: 151 \\
4: 149 \\
4: 145 \\
4: 141 \\
5: 148 \\
5: 143\end{array}$ & $\begin{array}{l}4.75 \\
3.44 \\
3.44 \\
3.44 \\
3.14 \\
3.15\end{array}$ & $\begin{array}{l}3.05 \\
2.44 \\
2.44 \\
2.44 \\
2.27 \\
2.27\end{array}$ \\
\hline $9-10 \ldots \ldots---$ & $\begin{array}{l}0,1 \\
0,2 \\
2,3 \\
3,4 \\
0,5 \\
5,6\end{array}$ & $\begin{array}{r}0.71 \\
3.58 \\
14.33 \\
5.36 \\
12.01 \\
4.08\end{array}$ & $\begin{array}{l}2: 163 \\
5: 160 \\
5: 155 \\
4: 151 \\
8: 156 \\
6: 151\end{array}$ & $\begin{array}{l}4.74 \\
3.14 \\
3.14 \\
3.44 \\
2.62 \\
3.14\end{array}$ & $\begin{array}{l}3.05 \\
2.27 \\
2.27 \\
2.44 \\
2.01 \\
2.27\end{array}$ \\
\hline $9-11 \ldots \ldots$ & $\begin{array}{l}0,1 \\
1,2 \\
2,3 \\
0,4 \\
4,5\end{array}$ & $\begin{array}{r}2.80 \\
23.08 \\
5.74 \\
11.36 \\
4.95\end{array}$ & $\begin{array}{l}5: 148 \\
3: 145 \\
5: 140 \\
8: 145 \\
6: 139\end{array}$ & $\begin{array}{l}3.14 \\
3.90 \\
3.15 \\
2.63 \\
2.94\end{array}$ & $\begin{array}{l}2.27 \\
2.68 \\
2.27 \\
2.01 \\
2.16\end{array}$ \\
\hline $9-14$ & $\begin{array}{l}0,1 \\
1,2 \\
0,3 \\
3,4\end{array}$ & $\begin{array}{l}13.58 \\
12.67 \\
15.53 \\
12.86\end{array}$ & $\begin{array}{l}8: 163 \\
3: 160 \\
7: 164 \\
3: 161\end{array}$ & $\begin{array}{l}2.63 \\
3.89 \\
2.75 \\
3.89\end{array}$ & $\begin{array}{l}2.01 \\
2.68 \\
2.08 \\
2.68\end{array}$ \\
\hline $9-15$ & $\begin{array}{l}0,1 \\
1,2 \\
0,3 \\
3,4\end{array}$ & $\begin{array}{l}13.22 \\
13.92 \\
14.96 \\
13.95\end{array}$ & $\begin{array}{l}8: 151 \\
3: 148 \\
7: 152 \\
3: 149\end{array}$ & $\begin{array}{l}2.63 \\
3.90 \\
2.76 \\
3.90\end{array}$ & $\begin{array}{l}2.01 \\
2.68 \\
2.08 \\
2.68\end{array}$ \\
\hline $9-19$ & $\begin{array}{l}0,1 \\
0,2 \\
2,3 \\
0,4 \\
4,5\end{array}$ & $\begin{array}{c}7.09 \\
25.5 \\
5.47 \\
29.0 \\
7.14\end{array}$ & $\begin{array}{l}2: 168 \\
8: 162 \\
4: 158 \\
7: 163 \\
3: 160\end{array}$ & $\begin{array}{l}4.72 \\
2.60 \\
3.43 \\
2.75 \\
3.90\end{array}$ & $\begin{array}{l}3.05 \\
2.00 \\
2.43 \\
2.07 \\
2.67\end{array}$ \\
\hline $9-20 \ldots$ & $\begin{array}{l}0,1 \\
0,2 \\
2,3 \\
0,4 \\
4,5\end{array}$ & $\begin{array}{c}6.08 \\
23.1 \\
6.27 \\
26.6 \\
6.22\end{array}$ & $\begin{array}{l}2: 156 \\
8: 150 \\
4: 146 \\
7: 151 \\
4: 147\end{array}$ & $\begin{array}{l}4.75 \\
2.63 \\
3.43 \\
2.76 \\
3.44\end{array}$ & $\begin{array}{l}3.05 \\
2.00 \\
2.44 \\
2.08 \\
2.43\end{array}$ \\
\hline
\end{tabular}

$\mathrm{T}_{\mathrm{ABLE}}$ 9-34. "F" values for significance of reduction of variance due to added variables-Continued

\begin{tabular}{|c|c|c|c|c|c|}
\hline \multirow{2}{*}{ Table } & \multirow{2}{*}{ Equations* } & \multirow{2}{*}{$\begin{array}{l}\text { "F" } \\
\text { ratio }\end{array}$} & \multirow{2}{*}{ D.F. } & \multicolumn{2}{|c|}{ Critical " $F$ " Ratio } \\
\hline & & & & $\alpha=0.01$ & $\alpha=0.05$ \\
\hline $9-23 \ldots$ & $\begin{array}{l}0,1 \\
0,2 \\
2,3 \\
0,4 \\
4,5\end{array}$ & $\begin{array}{r}2.75 \\
19.03 \\
2.82 \\
18.59 \\
2.71\end{array}$ & $\begin{array}{l}2: 167 \\
7: 162 \\
4: 158 \\
7: 162 \\
3: 159\end{array}$ & $\begin{array}{l}4.74 \\
2.75 \\
3.43 \\
2.75 \\
3.89\end{array}$ & $\begin{array}{l}3.05 \\
2.08 \\
2.44 \\
2.08 \\
2.68\end{array}$ \\
\hline $9-24 \ldots \ldots$ & $\begin{array}{l}0,1 \\
0,2 \\
2,3 \\
0,4 \\
4,5\end{array}$ & $\begin{array}{r}2.25 \\
18.95 \\
3.18 \\
18.44 \\
2.50\end{array}$ & $\begin{array}{l}2: 155 \\
7: 150 \\
3: 147 \\
7: 150 \\
3: 147\end{array}$ & $\begin{array}{l}4.75 \\
2.76 \\
3.90 \\
2.76 \\
3.90\end{array}$ & $\begin{array}{l}3.05 \\
2.08 \\
2.68 \\
2.08 \\
2.68\end{array}$ \\
\hline $9-27 \ldots \ldots$ & $\begin{array}{l}0,1 \\
0,2 \\
2,3 \\
0,4 \\
4,5\end{array}$ & $\begin{array}{r}3.89 \\
20.75 \\
4.32 \\
23.77 \\
4.14\end{array}$ & $\begin{array}{l}2: 165 \\
9: 158 \\
4: 154 \\
8: 159 \\
4: 155\end{array}$ & $\begin{array}{l}4.74 \\
2.52 \\
3.44 \\
2.63 \\
3.44\end{array}$ & $\begin{array}{l}3.05 \\
1.93 \\
2.44 \\
2.01 \\
2.44\end{array}$ \\
\hline $9-28 \ldots$ & $\begin{array}{l}0,1 \\
0,2 \\
2,3 \\
0,4 \\
4,5\end{array}$ & $\begin{array}{r}3.10 \\
26.25 \\
4.38 \\
30.61 \\
3.47\end{array}$ & $\begin{array}{l}2: 153 \\
7: 148 \\
4: 144 \\
6: 149 \\
5: 144\end{array}$ & $\begin{array}{l}4.75 \\
2.76 \\
3.44 \\
2.94 \\
3.15\end{array}$ & $\begin{array}{l}3.05 \\
2.08 \\
2.44 \\
2.16 \\
2.27\end{array}$ \\
\hline $9-31 \ldots$ & $\begin{array}{l}0,1 \\
0,2 \\
2,3 \\
0,4 \\
4,5\end{array}$ & $\begin{array}{r}3.04 \\
27.64 \\
4.39 \\
33.91 \\
4.23\end{array}$ & $\begin{array}{l}2: 165 \\
7: 160 \\
4: 156 \\
6: 161 \\
4: 157\end{array}$ & $\begin{array}{l}4.74 \\
2.75 \\
3.44 \\
2.92 \\
3.44\end{array}$ & $\begin{array}{l}3.05 \\
2.08 \\
2.44 \\
2.16 \\
2.44\end{array}$ \\
\hline $9-32 \ldots$ & $\begin{array}{l}0,1 \\
0,2 \\
2,3 \\
0,4 \\
0,5 \\
5,6\end{array}$ & $\begin{array}{r}2.52 \\
27.77 \\
4.07 \\
32.24 \\
34.09 \\
4.07\end{array}$ & $\begin{array}{l}2: 153 \\
7: 148 \\
4: 144 \\
5: 150 \\
6: 149 \\
4: 145\end{array}$ & $\begin{array}{l}4.75 \\
2.76 \\
3.44 \\
3.15 \\
2.93 \\
3.44\end{array}$ & $\begin{array}{l}3.05 \\
2.08 \\
2.44 \\
2.27 \\
2.16 \\
2.44\end{array}$ \\
\hline
\end{tabular}

*Equation 0 refers to the variance for the values themselves with no fitted equation for the $A E+N A E$ cements.

\subsection{Results of Duplicate Determinations}

The results of a series of duplicate determinations made on 20 non-air-entraining cements are presented in table $9-35$. The range of values with this group of cements was not so great as was obtained with those of the larger study. The S.D. values of the duplicate determinations are naturally much smaller than those obtained for the calculated equations. The duplicate determinations, though made on different days, did not extend over so long a period of time as the tests made on the larger group of cements. If laboratory conditions varied over the longer time period this may also have contributed to higher S.D. values.

\subsection{Comparative Test-Values on Other Hy- draulic Cements}

The restrained and nonrestrained shrinkage tests were also made on two commercial portland-pozzolan cements and seven portlandblast-furnace-slag cements using the same test method previously described with neat cement pastes of normal consistency. The average time of cracking of the annular specimens was 11.3 $\mathrm{hr}$ with a range of 1.6 to $27.4 \mathrm{hr}$. The average shrinkage of the nonrestrained bars at the time of cracking of the annular specimens was 0.043 percent with a range of 0.016 percent to 0.074 


\begin{tabular}{|c|c|c|c|c|}
\hline Test & $\begin{array}{c}\text { Range of values for } \\
\text { cements used for } \\
\text { duplicate determinations }\end{array}$ & \begin{tabular}{|} 
Estimated \\
S.D. for \\
duplicate \\
determinations
\end{tabular} & $\begin{array}{c}\text { Estimated } \\
\text { S.D. values } \\
\text { for equations }\end{array}$ & $\begin{array}{c}\text { Eq and table } \\
\text { in text }\end{array}$ \\
\hline $\begin{array}{l}\text { Shinkage } 24 \text { hr } \\
\text { Shrinkage } 7 \text { days } \\
\text { Shrinkage } 28 \text { days } \\
\text { Time of cracking annular specimens* } \\
\text { Shrinkage (non restrained) at time of cracking annular specimens } \\
\text { Shrinkage time of break divided by nonrestrained shrinkage at } 7 \text { days } \\
\text { Shrinkage time of break divided by nonrestrained shrinkage at } 28 \text { days. }\end{array}$ & $\begin{array}{l}0.047 \% \text { to } 0.082 \% \\
0.126 \% \text { to } 0.176 \% \\
0.185 \% \text { to } 0.276 \% \\
0.3 \mathrm{hr} \text { to } 2.33 \mathrm{hr} \\
0.015 \% \text { to } 0.058 \% \\
0.082 \text { to } 0.413 \\
0.051 \text { to } 0.264\end{array}$ & $\begin{array}{l}0.002 \\
0.003 \\
0.004 \\
0.87 \\
0.002 \\
0.014 \\
0.009\end{array}$ & $\begin{array}{l}0.010 \\
0.024 \\
0.029 \\
5.36 \\
0.009 \\
0.075 \\
0.049\end{array}$ & $\begin{array}{l}3 ; 9-3 \\
4 ; 9-7 \\
3 ; 9-11 \\
3 ; 9-24 \\
3 ; 9-28 \\
3 ; 9-32\end{array}$ \\
\hline
\end{tabular}

* These values were calculated on the time-of-break rather than the square root of the time of break.

percent. The average shrinkage at 28 days was 0.240 percent with a range of 0.174 percent to 0.339 percent. The values for shrinkage of the nonrestrained bars and time of cracking of the annular specimens were within the ranges of the values obtained with the portland cements.

\subsection{Comparison with Cements from Other Sources}

Mather [19] has reported values for the nonrestrained shrinkage and time of cracking of neat cements used in the Portland Cement Association long-time study of cement perfor- mance in concrete [20]. Annular specimens made of these cements had an average time of breaking of $13.5 \mathrm{hr}$ with a range of 0.4 to $31.8 \mathrm{hr}$. The 28-day nonrestrained shrinkage of these cements averaged 0.207 percent with a range of 0.147 to 0.313 percent. The average time of breaking of annular specimens made of these cements was somewhat greater, (13.5 versus $10.4 \mathrm{hr}$ ) indicated in this report, and the percentage shrinkage at 28 days somewhat lower for these cements, $(0.207$ versus 0.225$)$ indicated in this report. The averages and ranges of values reported for both groups of cements were in reasonable agreement.

\section{Discussion}

\subsection{Nonrestrained Shrinkage Versus Age}

The average values for percentage shrinkage of the neat portland cement bars of normal consistency after curing for $24 \mathrm{hr}$ in moist air, and then exposed to laboratory air were presented in tables $9-2,9-6,9-10$ and $9-14$ for 1 , 7, 28 days and 6 months. The average values for the NAE cements are also presented graphically in figure 9-7. Also presented in this figure are percentage-shrinkage values for six individual cements at $1 \mathrm{hr}$ to 1 year (on a $\log$ scale) to indicate the approximate range of values obtained. (Using the log scale for time resulted in the concavity of these curves.) Approximately 85 percent of the 1-year shrinkage had occurred at 28 days and there appeared to be very little shrinkage of most of the specimens after 6 months. The annular specimens of the three cements represented by the upper three curves (labeled 1, 2, and 3) cracked at $0.1,0.6$, and $1.1 \mathrm{hr}$, whereas those represented by the lower three curves (labeled 4,5 , and 6 ) cracked at 22, 14, and $17 \mathrm{hr}$ respectively.

It is generally recognized that variations of $\mathrm{CO}_{2}$ content in the laboratory air may have been a contributing factor to the shrinkage values which were obtained. However, the specimens were all made in one laboratory during a period of about 3 months, and carbonation may be expected to affect all specimens by about the same amount and would not have affected the relative values obtained.

\subsection{Trends of Variables}

Single equations from each of the tables relating the variables associated with values obtained for shrinkage at the various ages, shrinkage ratios of the prisms, and time of cracking of the annular specimens, all made of NAE cements, are presented in table 9-36. The equations are presented vertically instead of horizontally, and the coef./s.d. ratios, and calculated ranges of contributions of the independent variables are presented as in previous sections.

It may be noted in table 9-36 that an increase in the $\mathrm{C}_{3} \mathrm{~A}$ was probably associated with a decrease in SHBR but the effect was of minor importance. An increase in $\mathrm{C}_{3} \mathrm{~A}$ was associated with lower shrinkage at 1,7 , and 28 days when used with $\mathrm{C}_{3} \mathrm{~A} / \mathrm{SO}_{3}$ and $\mathrm{SO}_{3}$ as well as other additional variables. An increase in the $\mathrm{C}_{3} \mathrm{~A}$ content is normally associated with greater shrinkage but, as indicated by Lerch [14] and Picket [15], the shrinkage of mortars and concretes made of high $\mathrm{C}_{3} \mathrm{~A}$ cements may be substantially reduced by use of an optimum gypsum content. The interaction of the three independent variables $\mathrm{C}_{3} \mathrm{~A}, \mathrm{C}_{3} \mathrm{~A} / \mathrm{SO}_{3}$ and $\mathrm{SO}_{3}$ in the equations may have accounted for the negative sign for the $\mathrm{C}_{3} \mathrm{~A}$ coefficient. The effect of differences in $\mathrm{C}_{3} \mathrm{~A}, \mathrm{C}_{3} \mathrm{~A} / \mathrm{SO}_{3}$, and $\mathrm{SO}_{3}$ on shrinkage of the neat bars was relatively great. It may be noted that for the neat cement bars, moist cured for $24 \mathrm{hr}$, an increase in the $\mathrm{C}_{3} \mathrm{~A}$ / 


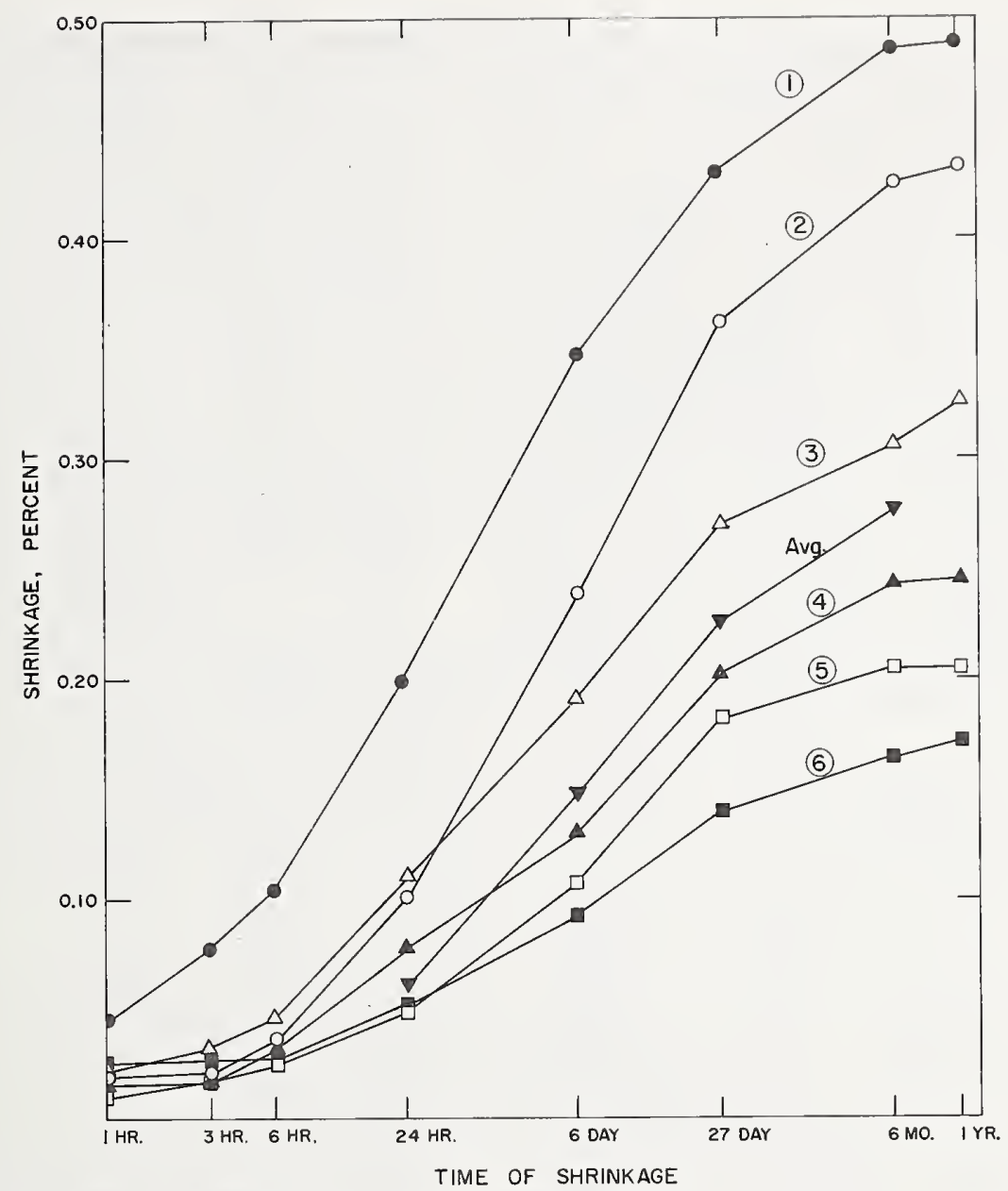

FIGURE 9-7. Results of plotting the average percentage shrinkage of neat portland cement pastes of normal consistency cured for 24 hours in moist air and then exposed to laboratory air for periods up to 6 months.

Also presented are the percentage-shrinkage values of six individual cements (labeled $1,2,3,4,5$, and 6 ) versus time, selected to show the range of values obtained.

$\mathrm{SO}_{3}$ ratio and an increase in $\mathrm{SO}_{3}$ were both associated with greater shrinkage, the $\mathrm{C}_{3} \mathrm{~A} /$ $\mathrm{SO}_{3}$ at $1,7,28$ days and 6 months, and the $\mathrm{SO}_{3}$ at 1 and 7 days.

The samples of the cements used for these shrinkage tests were obtained at a time when the upper limits of $\mathrm{SO}_{3}$ were lower than they are in present specifications. It is therefore probable that the amounts of $\mathrm{SO}_{3}$ were below the optimum values for most, if not all, of the cements. It would, therefore, be of questionable value to use the coefficients of $\mathrm{SO}_{3}, \mathrm{C}_{3} \mathrm{~A} / \mathrm{SO}_{3}$, and $\mathrm{C}_{3} \mathrm{~A}$ with the $\mathrm{SO}_{3}$ values permitted in present specifications. Neither $\mathrm{C}_{3} \mathrm{~A}, \mathrm{C}_{3} \mathrm{~A} / \mathrm{SO}_{3}$ nor $\mathrm{SO}_{3}$ had coef./s.d. ratios greater than 1 in the equations for the time of cracking of the annular specimens or the shrinkage ratios, SB/S7 or $\mathrm{SB} / \mathrm{S} 28$. The effect of $\mathrm{C}_{3} \mathrm{~A}$ and $\mathrm{SO}_{3}$ as well as other independent variables associated with the shrinkage of concrete specimens will be dis- cussed in the next section of this series of articles (see page 37).

In table 9-36 it may be noted that an increase in the $\mathrm{C}_{4} \mathrm{AF}$ may be associated with a decrease in shrinkage at $24 \mathrm{hr}$, and possibly with an increase in the shrinkage ratios $\mathrm{SB} / \mathrm{S} 7$ and $\mathrm{SB} / \mathrm{S} 28$. An increase in $\mathrm{C}_{4} \mathrm{AF}$ also appeared to be associated with an increase in the time of cracking of the annular specimens.

Differences in the $\mathrm{C}_{3} \mathrm{~S}$ and $\mathrm{C}_{2} \mathrm{~S}$ contents of the cements were not significantly related to the shrinkage values or ratios obtained for the different cements. An increase in $\mathrm{C}_{2} \mathrm{~S}$ may possibly be associated with a longer time period for the restrained annular specimens to break.

Higher $\mathrm{MgO}$ values appear associated with lower SHBR values and lower shrinkage ratios but possibly with greater shrinkage of the neat cement bars at 28 days and 6 months. 
TABLE 9-36. Coefficients, coef./s. d. ratios, and calculated ranges of contributions of independent variables associated with nonrestrained shrinkage at various ages of neat cement bars of normal consistency, time of break of annular specimens, and shrinkage ratios for NAE cements

\begin{tabular}{|c|c|c|c|c|c|c|c|c|}
\hline Equation & 3 & 3 & 4 & 3 & 2 & 3 & 3 & 3 \\
\hline Table & $9-24$ & $9-3$ & $9-7$ & $9-11$ & $9-15$ & $9-20$ & $9-28$ & $9-32$ \\
\hline $\begin{array}{l}\text { Dependent Variable } \\
\text { Constant }\end{array}$ & $\begin{array}{c}\text { SHBR } \\
\stackrel{=}{=} \\
+0.101\end{array}$ & $\begin{array}{c}\stackrel{\mathrm{SH} 24}{=} \\
-0.020\end{array}$ & $\begin{array}{c}\text { SHO7 } \\
= \\
-0.032\end{array}$ & $\begin{array}{c}\mathrm{SH} 28 \\
= \\
-0.023\end{array}$ & $\begin{array}{c}\text { SH } 6 \mathrm{M} \\
= \\
+0.004\end{array}$ & $\begin{array}{l}(\mathrm{TOBR}) 0.5 \\
=6.24\end{array}$ & $\begin{array}{r}\mathrm{SB} / \mathrm{S} 7 \\
= \\
+0.678\end{array}$ & $\begin{array}{c}\mathrm{SB} / \mathrm{S} 28 \\
= \\
+0.440\end{array}$ \\
\hline $\begin{array}{l}\mathrm{C}_{3} \mathrm{~A}_{\text {, coef }} \\
\text { Cocf./s,d-1.- } \\
\text { Calculated range * }\end{array}$ & $\begin{array}{l}-0.00067 \\
2.5 \\
0.001\end{array}$ & $\begin{array}{l}-0.00553 \\
3.2 \\
0.083\end{array}$ & $\begin{array}{l}-0.0165 \\
\quad 4.4 \\
\quad 0.248\end{array}$ & $\begin{array}{l}-0.0204 \\
4.2 \\
0.306\end{array}$ & $\begin{array}{l}-0.0060 \\
2.3 \\
0.090\end{array}$ & - & & \\
\hline $\begin{array}{l}\text { C4AF, coef } \\
\text { Coef./s,d } \\
\text { Calculated range. }\end{array}$ & 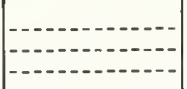 & $\begin{array}{l}-0.00137 \\
3.0 \\
0.018\end{array}$ & $\begin{array}{c}* *-0.00192 \\
1.9 \\
0.025\end{array}$ & $\begin{array}{c}* *-0.00217 \\
1.7 \\
0.028\end{array}$ & 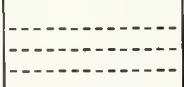 & $\begin{array}{l}+0.1455 \\
\quad 4.8 \\
\quad 1.89\end{array}$ & $\begin{array}{c}+0.0087 \\
3.1 \\
0.113\end{array}$ & $\begin{aligned}+ & 0.0053 \\
& 2.9 \\
& 0.069\end{aligned}$ \\
\hline $\begin{array}{l}\mathrm{C}_{3} \mathrm{~S} \text {, coef } \\
\text { Coef./s.d-d range. } \\
\text { Calculated }\end{array}$ & & .... & 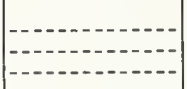 & 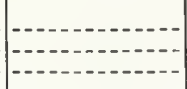 & $\begin{array}{c}* *+0.00067 \\
1.2 \\
0.027\end{array}$ & & & \\
\hline $\begin{array}{l}\mathrm{C}_{2} \mathrm{~S} \text {, coef } \\
\text { Coef./s,d. } \\
\text { Calculated range. }\end{array}$ & & & - n-.- & - & $\mid-1-1-1$ & $\begin{aligned}+0.0307 \\
2.9 \\
1.39\end{aligned}$ & $\begin{array}{c}* *-0.0014 \\
1.5 \\
0.062\end{array}$ & $\begin{array}{c}* *+0.00102 \\
1.7 \\
0.046\end{array}$ \\
\hline $\begin{array}{l}\mathrm{C}_{3} \mathrm{~A} / \mathrm{SO}_{3} \text {, coef } \\
\text { Coef./s.d } \\
\text { Calculated range-- }\end{array}$ & & $\begin{array}{l}+0.0101 \\
3.4 \\
\quad 0.098\end{array}$ & $\begin{array}{l}+0.0281 \\
\quad 4.3 \\
\quad 0.273\end{array}$ & $\begin{array}{l}+0.0368 \\
\quad 4.2 \\
\quad 0.357\end{array}$ & $\begin{array}{l}+0.0175 \\
\quad 3.5 \\
\quad 0.170\end{array}$ & 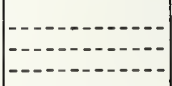 & $\mid-1-1$ & 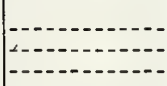 \\
\hline $\begin{array}{l}\mathrm{SO}_{3}, \text { coef } \\
\text { Coef./s,d........... } \\
\text { Calculated range.. }\end{array}$ & -- & $\begin{array}{c}+0.0351 \\
4.4 \\
\quad 0.084\end{array}$ & $\begin{array}{l}+0.0722 \\
\quad 4.2 \\
\quad 0.174\end{array}$ & $\begin{array}{l}+0.0788 \\
\quad 2.5 \\
0.188\end{array}$ & (-n & $\begin{array}{c}* *-0.266 \\
1.1 \\
0.64\end{array}$ & 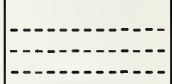 & 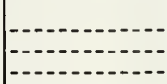 \\
\hline $\begin{array}{l}\text { MgO, coef } \\
\text { Coef./s.d } \\
\text { Calculated range. }\end{array}$ & $\begin{array}{l}-0.00202 \\
3.0 \\
0.010\end{array}$ & & 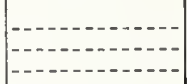 & $\begin{array}{l}+0.0054 \\
2.4 \\
0.044\end{array}$ & $\begin{array}{l}+0.00879 \\
2.8 \\
0.044\end{array}$ & $\begin{array}{l}-0.1475 \\
2.4 \\
0.73\end{array}$ & $\begin{array}{l}-0.0221 \\
4.1 \\
0.111\end{array}$ & $\begin{array}{l}-0.0141 \\
3.9 \\
0.070\end{array}$ \\
\hline $\begin{array}{l}\mathrm{Na}_{2} \mathrm{O} \text {, coef } \\
\mathrm{Coef} \text {./s.d } \\
\text { Calculated range- }\end{array}$ & $\begin{array}{l}-0.0150 \\
3.3 \\
0.011\end{array}$ & $\begin{array}{c}* *+0.0100 \\
1.9 \\
0.008\end{array}$ & $\begin{array}{l}+0.3133 \\
\quad 2.5 \\
\quad 0.023\end{array}$ & $\begin{array}{c}+0.0921 \\
\quad 6.0 \\
0.069\end{array}$ & $\begin{array}{l}+0.1392 \\
\quad 6.9 \\
0.104\end{array}$ & $\begin{array}{c}-1.54 \\
3.8 \\
1.15\end{array}$ & $\begin{array}{l}-0.1594 \\
4.4 \\
0.120\end{array}$ & $\begin{array}{l}-0.1292 \\
5.5 \\
0.097\end{array}$ \\
\hline $\begin{array}{l}\mathrm{K}_{2} \mathrm{O} \text {, coef } \\
\text { Coef./s.d } \\
\text { Calculated range. }\end{array}$ & $\begin{array}{l}-0.0229 \\
5.0 \\
0.025\end{array}$ & $\begin{array}{c}+0.0200 \\
\quad 4.4 \\
\quad 0.022\end{array}$ & $\begin{array}{l}+0.0383 \\
\quad 3.5 \\
\quad 0.042\end{array}$ & $\begin{array}{l}+0.0779 \\
5.4 \\
\quad 0.086\end{array}$ & $\begin{array}{l}+0.1233 \\
6.0 \\
0.135\end{array}$ & $\begin{array}{c}-2.27 \\
5.7 \\
2.50\end{array}$ & $\begin{array}{c}-0.2421 \\
6.7 \\
0.266\end{array}$ & $\begin{array}{c}-0.1695 \\
7.1 \\
0.186\end{array}$ \\
\hline $\begin{array}{l}\text { APF, coef } \\
\text { Coef./s.d } \\
\text { Calculated rangc. }\end{array}$ & $\begin{array}{l}-0.0000124 \\
8.0 \\
0.043\end{array}$ & $\begin{array}{l}+0.0000046 \\
2.3 \\
\quad 0.013\end{array}$ & $\begin{array}{l}+0.0000088 \\
2.0 \\
0.026\end{array}$ & $\begin{array}{l}+0.0000133 \\
\quad 2.3 \\
\quad 0.040\end{array}$ & $\begin{array}{l}+0.0000224 \\
2.7 \\
0.067\end{array}$ & $\begin{array}{l}-0.001002 \\
6.0 \\
3.07\end{array}$ & $\begin{array}{l}-0.000090 \\
7.2 \\
0.268\end{array}$ & $\begin{array}{l}-0.0000548 \\
6.7 \\
0.164\end{array}$ \\
\hline $\begin{array}{l}\text { Air, } 1: 4 \text { mortar, coef } \\
\text { Coef./s.d } \\
\text { Calculated range }\end{array}$ & $-\cdots--1$ & - & $\begin{array}{c}* *+0.00144 \\
1.2 \\
0.029\end{array}$ & & & & $\begin{array}{l}-- \\
-- \\
--\end{array}$ & $\mid-1-1-1$ \\
\hline $\begin{array}{l}\text { Loss, coef } \\
\text { Coef./s.d } \\
\text { Calculated range. }\end{array}$ & $\begin{array}{l}+0.0041 \\
2.7 \\
\quad 0.010\end{array}$ & & - & - & & $\begin{array}{c}+0.544 \\
\quad 4.1 \\
\quad 1.80\end{array}$ & (1) & -10 \\
\hline $\begin{array}{l}\text { Ba, coef } \\
\text { Coef./s.d } \\
\text { Calculated range. }\end{array}$ & 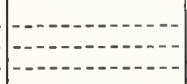 & $\begin{array}{c}* *+0.0523 \\
1.6 \\
0.010\end{array}$ & $\begin{array}{l}+0.1828 \\
2.7 \\
0.037\end{array}$ & $\begin{aligned}+ & 0.3194 \\
& 3.4 \\
& 0.064\end{aligned}$ & $\begin{aligned}+ & 0.575 \\
& 5.0 \\
& 0.115\end{aligned}$ & $\begin{array}{c}-8.94 \\
4.0 \\
1.79\end{array}$ & 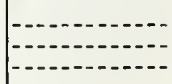 & - \\
\hline $\begin{array}{l}\text { Cr, coef } \\
\text { Coef./s.d } \\
\text { Calculated range. }\end{array}$ & - & $\begin{array}{c}+0.4422 \\
2.1 \\
0.009\end{array}$ & & & & & $\mid$\begin{tabular}{l}
$-1-1$ \\
\hdashline--1
\end{tabular} & $\mid-1-1$ \\
\hline $\begin{array}{l}\mathrm{Cu}, \text { coef } \\
\text { Coef,/s.d-d } \\
\text { Calculated range. }\end{array}$ & $\begin{array}{l}-0.2483 \\
2.4 \\
0.012\end{array}$ & & & - & - & & $\begin{array}{l}-1.785 \\
2.1 \\
0.089\end{array}$ & $\begin{array}{c}-1.141 \\
2.0 \\
0.057\end{array}$ \\
\hline $\begin{array}{l}\mathrm{Ni} \text {, coef } \\
\text { Coef./s.d.d. } \\
\text { Calculated range. }\end{array}$ & & & & & $\begin{array}{l}+2.617 \\
2.2 \\
0.052\end{array}$ & & $\begin{array}{r}* *-3.418 \\
1.6 \\
0.068\end{array}$ & $\begin{aligned} * *-2.083 \\
1.4 \\
0.042\end{aligned}$ \\
\hline $\begin{array}{l}\text { P, coef } \\
\text { Coef./s.d.d. } \\
\text { Calculated range.- }\end{array}$ & $-1-1$ & $\begin{array}{c}* *+0.0130 \\
1.6 \\
0.006\end{array}$ & $\begin{array}{c}* *+0.0262 \\
1.6 \\
0.013\end{array}$ & $\begin{array}{l}+0.0489 \\
2.3 \\
\quad 0.024\end{array}$ & --- & - & $-\cdots$ & {$\left[\begin{array}{l}-1 \\
\hdashline-1-1\end{array}\right.$} \\
\hline $\begin{array}{l}\text { Rb, coef } \\
\text { Coef./s.d.d. } \\
\text { Calculated range. }\end{array}$ & $\begin{array}{c}* * 0.6045 \\
1.3 \\
0.060\end{array}$ & 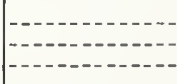 & $\begin{array}{c}+2.667 \\
2.4 \\
0.027\end{array}$ & $\begin{array}{c}+3.021 \\
2.1 \\
0.030\end{array}$ & $\begin{array}{c}* *+3.686 \\
1.8 \\
0.037\end{array}$ & $\begin{array}{c}-96.5 \\
2.4 \\
0.96\end{array}$ & $\begin{array}{r}* *-6.403 \\
1.7 \\
0.064\end{array}$ & $\begin{array}{c}* *-4.126 \\
1.7 \\
0.041\end{array}$ \\
\hline $\begin{array}{l}\text { V, coef } \\
\text { Coef./s.d-d } \\
\text { Calculated range. }\end{array}$ & $\begin{array}{c}* *-0.0555 \\
1.3 \\
0.006\end{array}$ & - & & 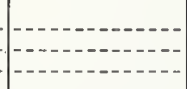 & & & $\begin{array}{r}* *-0.515 \\
1.4 \\
0.052\end{array}$ & $\begin{array}{c}* *-0.3532 \\
1.4 \\
0.035\end{array}$ \\
\hline $\begin{array}{l}\text { Zn, coef } \\
\text { Coef./s.d. } \\
\text { Calculated range... }\end{array}$ & 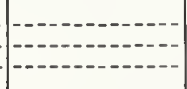 & $\begin{array}{c}* *-0.0323 \\
1.1 \\
0.006\end{array}$ & $\mid$\begin{tabular}{cc}
$-\cdots$ \\
\hdashline$-\cdots$
\end{tabular} & $\begin{array}{c}* *-0.0964 \\
1.1 \\
0.019\end{array}$ & - & & $-1-1$ & - \\
\hline $\begin{array}{l}\text { Zr, coef } \\
\text { Coel./s.d }-1 .-1 . \\
\text { Calculated range.. }\end{array}$ & & & & & & $\begin{array}{r}* *-2.89 \\
1.7 \\
1.44\end{array}$ & ( & $\cdots$ \\
\hline
\end{tabular}

* The calculated range was computed from the range of values for the cements times the coefficient for each independent variable. ** The independent variable is probably not significant as the coef./s.d. ratio is less than 2. 
The results reported in table 9-36 confirm previously reported information that alkalies are associated with shrinkage. An increase in $\mathrm{Na}_{2} \mathrm{O}$ was associated with lower nonrestrainedshrinkage values at the time of cracking of the restrained-shrinkage annular specimen, as well as the shorter period of time of cracking of the annular specimens. An increase in $\mathrm{Na}_{2} \mathrm{O}$ was also associated with higher shrinkage values at 28 days and 6 months and possibly also at 7 days.

An increase in $\mathrm{K}_{2} \mathrm{O}$ was also associated with lower SHBR values and lower TOBR values and with higher shrinkage at all ages of 1 day to 6 months. Differences in $\mathrm{K}_{2} \mathrm{O}$ values and fineness of the cements appear to be the major factors causing early cracking of the annular specimens made of neat cements.

An increase in the fineness also appears associated with lower nonrestrained shrinkage values of the bars at the time of cracking of the annular specimens as well as the shrinkage ratios. Increases in fineness may possibly be associated with greater shrinkage values at ages 1 day to 6 months, but the coef./s.d. ratios obtained were significant only at the 5 -percent probability level.

An increase in the loss on ignition may be associated with an increase in the time required for the annular specimens to crack, and an increase in the nonrestrained shrinkage of the bars at the time of cracking of the annular specimens.

Of the various trace elements in the cements, only $\mathrm{Ba}$ appeared highly significant in its relationship to values obtained in any of the tests. An increase in Ba appeared associated with an increase in shrinkage values at 28 days and 6 months and probably at 7 days. Increases in $\mathrm{Ba}$ are probably also associated with a shorter period of time for cracking of the annular specimens. Of the other trace elements, increases in $\mathrm{Cr}$ may be associated with increased 24-hr shrinkage, increases in $\mathrm{Cu}$ with decrease in nonrestrained shrinkage at the time of cracking of the annular specimens, increases in $\mathrm{Ni}$ with increases in 6-month shrinkage of the bars, increased $\mathrm{P}$ with increased 28-day shrinkage and increased $\mathrm{Rb}$ with increased 7 and 28-day nonrestrained shrinkage.

\subsection{Shrinkage Characteristics of Neat Cement Pastes Versus Compressive Strength of 1:2.75 (Cement to Sand) Mortars}

Two reports by A. de Sousa Coutinho [16, 17] indicated that with neat cement pastes, a greater cracking tendency was associated with higher strength and that the reverse was true with concretes. The findings by A. S. Coutinho may have contributed to the withdrawal of the proposed neat-cement restrained-shrinkage test from the RILEM specifications. No strength tests, either tensile or compressive, were made on the neat cement pastes used for the nonrestrained shrinkage tests or the time of cracking of the annular specimens. It therefore appeared desirable to determine the relationship of shrinkage values, ratios, and the time of cracking to the available compressive-strength data of the 1:2.75 (cement to graded Ottawa sand) mortars. These equations for the NAE cements are presented in table 9-37. Also presented are the reduction in variance or " $F$ " values resulting from the calculation of a constant and the coefficient of an independent variable. An " $F$ " value greater than 3.05 is significant at the 5-percent probability level and, if greater than 4.7, at the 1-percent probability level. It may be noted in table 9-37 that an increase in compressive-strength values of the mortar at 1, 3 and 7 days, (eqs 1,2, and 3) was associated with the 24-hr shrinkage of the neat cement bars. Higher compressive-strength values of the mortars at 1 year were associated with lower shrinkage values for the neat cement bars at 7 and 28 days and at 6 months (eqs 10, 15 and 20). (The compressive-strength values of the 2 -in cubes were all determined with moist specimens that had not been subjected to any drying cycles).

Higher compressive-strength values for the mortars at 1, 3, 7 and 28 days appeared associated with lower values of nonrestrained shrinkage of the neat cement bars at the time of cracking of the annular specimens, (eqs 21, 22,23 , and 24) as well as a shorter time for the annular specimens to crack, (eqs 26, 27, and 28). Equations 25 and 30 indicate that higher strength values for the mortars at 1 year may possibly be associated with higher nonrestrained shrinkage of the neat cements at the time of cracking of the annular specimens and a greater time before the annular specimens cracked. Equations 31 through 40, relating the nonrestrained-shrinkage ratios of the neat cements to the compressive strengths of the mortars, also indicate the reversal of the sign of the coefficient for the 1-year compressive-strength relationship.

The relationships in table 9-37 indicate that variables associated with the shrinkage tests of the neat cement pastes may also be associated with the compressive strengths. Referring to section 7 of this series and table 7-77 of section 7 [11] it was noted that, although higher values for fineness and $\mathrm{C}_{3} \mathrm{~A}$ were associated with higher compressive strengths at the early ages, higher values for $\mathrm{C}_{3} \mathrm{~A}$ were associated with lower strength at 1 year (ST1Y). Differences in fineness and $\mathrm{C}_{3} \mathrm{~A}$ values were of major significance in the equations for strength of the mortars at 1 and 3 days but not in the equations for shrinkage of the neat cements at $24 \mathrm{hr}$. A comparison of the effect of the alkalies $\mathrm{Na}_{2} \mathrm{O}$ and $\mathrm{K}_{2} \mathrm{O}$ in tables $7-77$ and $9-36$ are also of 
TABLE 9-37. Relationship between shrinkage, shrinkage ratios, and time of cracking of neat portland cement pastes, and the compressive strength in psi of 1:2.75 (cement to sand) mortars at different ages

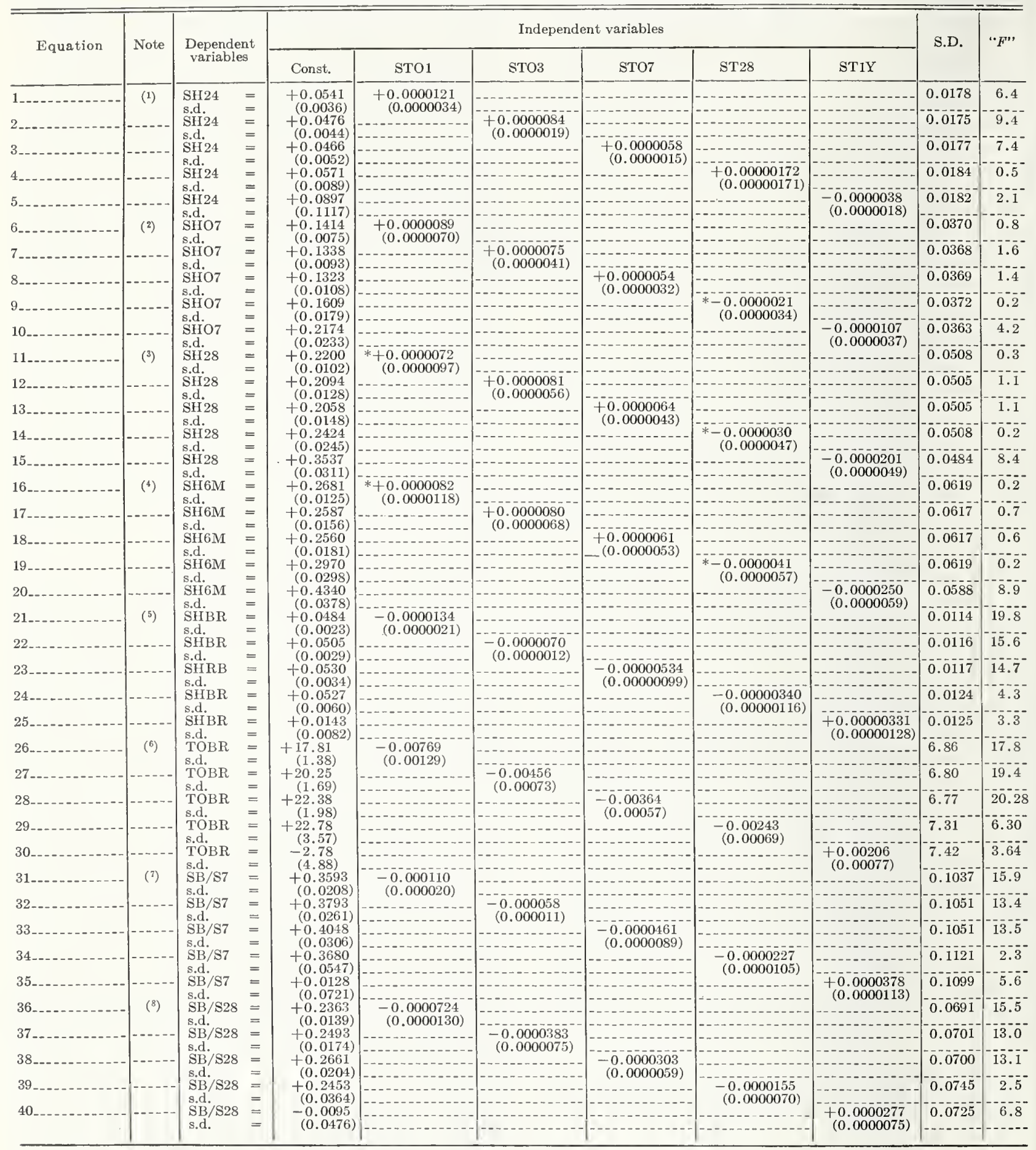

* Coef./s.d. ratio less than 1.

\begin{tabular}{|c|c|c|c|c|}
\hline \multicolumn{4}{|c|}{160 cements, $\mathrm{Avg}=0.0658, \mathrm{~S} . \mathrm{D}$} & \\
\hline & is & $=0.1501$ & "* & $=0.0371$ \\
\hline & “ & $=0.2670$, & “ & $=0.0507$ \\
\hline & “ & $=0.2761$, & 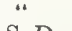 & $=0.0618$ \\
\hline & ements, Avg & $=0.0$ & S. D. & $=0$. \\
\hline & & $=10$ & & $=7$. \\
\hline & 4 & $=0.2$ & • & $=0$. \\
\hline & " & $=0.1$ & 14 & $=0.0754$ \\
\hline
\end{tabular}


interest. Differences in $\mathrm{Na}_{2} \mathrm{O}$ were not associated with early strength in equations in table $7-77$ but $\mathrm{K}_{2} \mathrm{O}$ was. In equations of table 9-36 differences in $\mathrm{K}_{2} \mathrm{O}$ content was of major significance in the time of cracking of the annular specimens. Increases in both $\mathrm{Na}_{2} \mathrm{O}$ and $\mathrm{K}_{2} \mathrm{O}$ were associated with decreases in the nonrestrained shrinkage at the time of cracking of the annular specimens.

The literature on shrinkage and cracking of portland cement pastes, mortars and concretes has indicated that many variables are involved. Among these are the size and shape of the specimens, the amount of hydration product, the gel-space ratios [21], the moisture gradient within a specimen, the moisture diffusivity, the ability of the structural units in the hydration products to adjust to the stresses produced by shrinkage called "creep" or semi-plastic flow, and the amount of restraint offered by unhydrated cement particles in the cement paste, or the aggregates in the mortars or concretes.

The neat cement pastes of normal consistency, with a water-cement ratio of about 0.25 , hydrated for only $24 \mathrm{hr}$, may be expected to have a considerable amount of unhydrated cement, and the unhydrated particles would be closely adjacent to each other. This would result in a considerable restraint to shrinkage in the paste, or at least more so than in concrete where the water-cement ratio may be more than twice as great. Shrinkage tests made on concrete are usually made after a longer curing period and under these conditions, the amount and the nature of the hydration product may also differ from that at $24 \mathrm{hr}$.

\section{Summary and Conclusions}

(1) Determinations were made of the drying-shrinkage of $1 \times 1 \times 10$-in (effective gage length) bars made of neat cement pastes. The specimens made of 183 cements were stored for $24 \mathrm{hr}$ in moist air and then exposed to laboratory air at 50 percent relative humidity. Tests were also made of the time of cracking of annular specimens made of the same pastes and restrained from shrinking by a steel disc. The storage conditions were the same as for the bars. Multivariable regression equations were used to determine which of the independent variables or combinations of variables, such as fineness and composition of the cements, as well as trace elements in the cements were associated to a significant degree with the test-values obtained. The test values used as dependent variables were the percentage shrinkage at 1, 7, 28 days, and 6 months, the percentage shrinkage of the bars at the time of cracking of the annular specimens, and the time of cracking of the annular specimens restrained from shrinking. Also used as dependent variables were the ratios of the nonrestrained shrinkage at the time of cracking of the annular specimens to the nonrestrained shrinkage at 7 and 28 days.

(2) The frequency distributions of the cements with respect to percentage shrinkage at 1, 7, 28 days, and 6 months indicated a wide distribution of values especially for the Type I cements. There was an overlapping of the percentage-shrinkage values of the cements in the various types as classified. It is then not possible to say that a cement, because it conforms with the chemical composition and physical requirements of any one type of cement, will therefore have greater or less shrinkage than a cement meeting requirements for some other type.
(3) The time of cracking of the annular specimens ranged from $0.1 \mathrm{hr}$ to more than 40 hr after being removed from moist storage and placed in laboratory air. The average time of cracking was about $10 \mathrm{hr}$. Eighty-five percent of the Types III and IIIA, 59 percent of the Types I and IA, 41 percent of the Types II and IIA, and 7 percent of the Types IV and V cracked in less than $10 \mathrm{hr}$. The cements classified as Type I had the greatest range of values, but there was a great deal of overlapping of the values obtained for the cements of the different types.

(4) The percentage shrinkage of the bars at the time of cracking of the annular specimens ranged from about 0.010 percent to more than 0.065 percent with an average of about 0.035 percent. About 76 percent of the Types III and IIIA, 43 percent of the Types I and IA, 27 percent of the Types II and IIA, and 14 percent of the Types IV and $V$ had shrinkage values less than the average. This indicates, to some extent, the overlapping of values obtained with the different types of cement.

(5) The ratios of the percentage shrinkage of the neat cement bars at the time of cracking of the annular specimens to the shrinkage at 7 or 28 days were calculated as possible indications of plastic deformation or creep of the hydrated pastes. A considerable range of values was obtained, with overlapping of the values for the cements of the different types. The majority of the Types III and I cements had values below the average which was not the case with the Types II, IV, and V cements.

(6) An increase in the percentage water required for normal consistency of the neat cement pastes was associated with an increase in the shrinkage at $24 \mathrm{hr}$, but not at later ages. An increase in the percentage water required for normal consistency of the neat cement 
pastes was also associated with a decrease in the time of cracking of the annular specimens.

(7) Multivariable regression equations were calculated to determine which of the available independent variables were associated with the various determined shrinkage values or characteristics. Typical equations were compiled in table $9-36{ }^{12}$.

(7.1) Higher $\mathrm{C}_{3} \mathrm{~A} / \mathrm{SO}_{3}$ ratios were associated with higher shrinkage values at $1,7,28$ days, and 6 months when used together with $\mathrm{C}_{3} \mathrm{~A}$ and $\mathrm{SO}_{3}$ as independent variables. Under these conditions, higher $\mathrm{SO}_{3}$ values were also associated with higher shrinkage, but higher $\mathrm{C}_{3} \mathrm{~A}$ values were associated with lower shrinkage values. Differences in values of these independent variables showed the greatest association with differences in shrinkage values at 1,7 , and 28 days for all of the variables studied. None of these independent variables or combinations were significantly associated with the time of cracking of the annular specimens nor the shrinkage ratios.

(7.2) An increase in $\mathrm{C}_{4} \mathrm{AF}$ was associated with a decrease in shrinkage at $24 \mathrm{hr}$ and an increase in the time required for the annular specimens to crack.

(7.3) Differences in $\mathrm{C}_{3} \mathrm{~S}$ and $\mathrm{C}_{2} \mathrm{~S}$ of the cements were apparently not associated with the shrinkage values obtained. An increase in $\mathrm{C}_{2} \mathrm{~S}$ is probably associated with an increase in the time required for the annular specimens to crack.

(7.4) An increase in $\mathrm{MgO}$ may possibly be associated with an increase in shrinkage at 7 and 28 days and with a decrease in shrinkage of the bars at the time of cracking of the annular specimens.

(7.5) An increase in $\mathrm{Na}_{2} \mathrm{O}$ was associated with an increase in shrinkage at 28 days and 6 months and a decrease in the time of cracking of the annular specimens and the nonrestrained shrinkage when the annular specimens cracked.

(7.6) An increase in $\mathrm{K}_{2} \mathrm{O}$ was associated with an increase in shrinkage at all ages and with a decrease in the time of cracking of the annular specimens, and with a decrease of the nonrestrained shrinkage at the time of cracking of the annular specimens.

(7.7) An increase in the fineness of the cements was associated with a decrease in the nonrestrained shrinkage at the time of cracking of the annular specimens and with a decrease in the time required for the annular specimens to crack and possibly with an increase in shrinkage at all ages.

(7.8) An increase in the loss-on-ignition values was possibly associated with an increase in the time of cracking of the annular specimens

\footnotetext{
12 Remarks about relations with time of break of annular specimens are based on the square root of time of break. See footnote 10, subsection 5.5 .
}

and an increase in the nonrestrained shrinkage at the time of cracking.

(7.9) The use of trace elements found to have a coef./s.d. ratio greater than 1 in the equations resulted, in most instances, in a reduction in variance significant at the 1 -percent probability level. Except for $\mathrm{Ba}$, (and $\mathrm{Na}_{2} \mathrm{O}$ and $\mathrm{K}_{2} \mathrm{O}$, as previously mentioned), none of the individual trace elements were associated with the shrinkage characteristics to a highly significant degree. An increase in $\mathrm{Ba}$ is probably associated with an increase in shrinkage at 28 days and 6 months and possibly at 7 days. Increases in $\mathrm{Ba}$ and $\mathrm{Rb}$ are possibly associated with a decrease in the time required for the annular specimens to crack. $\mathrm{Cr}, \mathrm{Cu}, \mathrm{Ni}, \mathrm{P}$, and $\mathrm{Rb}$ may possibly be associated with shrinking at one or more ages.

(8) The use of the major oxides instead of the calculated potential compound-composition values of the cements (and also using the $\mathrm{Al}_{2} \mathrm{O}_{3} / \mathrm{SO}_{3}$ ratios) resulted in equations with approximately the same reduction in variance as when the compound-composition values were used.

(9) Equations computed for all cements, i.e., the air-entraining cements together with the non-air-entraining cements, resulted in coefficients and coef./s.d. ratios of the independent variables in reasonable accord with those obtained when only the non-air-entraining cements were used.

(10) An increase in compressive strength of the 1:2.75 (cement to Ottawa sand) mortars at 1 day was associated with an increase in shrinkage values at $24 \mathrm{hr}$ of the bars made of neat cement paste of normal consistency. An increase in compressive-strength values of these mortars at early ages was associated with a decrease in the time required for the annular specimens to crack and a decrease in nonrestrained shrinkage at the time of cracking of the annular specimens. An increase in the compressive-strength values of these mortars at 1 year was associated with an increase in the nonrestrained shrinkage of the neat cement bars at 7, 28 days, and 6 months.

(11) The estimated standard deviations of results of duplicate determinations made on different days were much lower than those computed from the equations using available independent variables. It therefore appears that other independent variables or combinations of independent variables may contribute to the shrinkage characteristics of hydrated neat portland pastes.

(12) The averages and ranges of values for 28-day shrinkage, and time of breaking with restrained shrinkage, of the cements used in this investigation were in reasonable agreement with those reported for the PCA longtime study of cement performance in concrete. 
In addition to the acknowledgements indicated in previous sections of this series of articles, special acknowledgements are made to M. R. DeFore and A. C. Figlia, who conducted most of the tests, and to Paul Worksman for studies of the reproducibility of the shrinkage values and characteristics.

\section{References}

[1] Symposium on the Chemistry of Cements, Stockholm, 1938, (Ingeniörsvetenskapsakademien, Stockholm 1939).

[2] Proceedings of the Third International Symposium on the Chemistry of Cement, London 1952, Cement and Concrete Association, London.

[3] Chemistry of Cement, Proceedings of the Fourth International Symposium, Mono. 43, Vol. 1, 2, Aug. 1962, U.S. Government Printing Office, Washington, D.C.

[4] International Method of Cement Testing, Bulletin De La Réunion des Laboratoires D'Essais et De Recherches Sur Les Materiaux et Les Constructions. RILEM Bulletin No. 12, Dec. 1952, 12 Rue Brancion, Paris.

[5] Blaine, R. L., Arni, H. T., and Foster, B. E., NBS Building Science Series No. 2, Interrelations between Cement and Concrete Properties, Part I, Section 1, Materials and techniques (1965).

[6] Blaine, R. L., Arni, H. T., and Clevenger, R. A., ibid., Section 2, Water requirements of portland cement.

[7] Blaine, R. L., Bean, Leonard, and Hubbard, Elizabeth K., ibid., Section 3, Occurrence of minor and trace elements in portland cement.

[8] Blaine, R. L., Arni, H. T., and Evans, D. N., NBS Building Science Series No. 5. Interrelations between Cement and Concrete Properties, Part 2, Section 4, Variables associated with expansion in the potential sulfate expansion test (1966).

[9] Blaine, R. L., and Arni, H. T., ibid., Section 5, Heat of hydration of portland cements.

[10] Blaine, R. L., and Arni, H. T., ibid., Section 6, Variables associated with small autoclave expansion values of portland cements.
[11] Blaine, R. L., Arni, H. T., and DeFore, M. R., NBS Building Science Series No. 8, Interrelations between Cement and Concrete Properties, Part 3, Section 7, Compressive strength of test mortars (1968).

[12] Blaine, R. L., Arni, H. T., and DeFore, M. R., ibid., Section 8, Compressive strength of steam cured portland cement mortars.

[13] Standard Methods for Mechanical Mixing of $\mathrm{Hy}-$ draulic Cement Pastes and Mortars of Plastic Consistency. ASTM Designation C305-65. ASTM Book of Standards, Part 9, June 1966, p. 313 .

[14] Lerch, William, Proceedings ASTM, 46, 1252 (1946).

[15] Pickett, Gerald, Journal ACI, 19, No. 2, 149 (1947).

[16] Coutinho, A. de Sousa, Lab. Nac. Eng. Civil Pub. No. 57, (1954) (in Portuguese).

[17] Coutinho, A. de Sousa, Materiaux et Constructions, Recherches et Essais, RILEM Bulletin No. 5, Dec. 1959 , p. 26.

[18] Natrella, M. G., Experimental Statistics, NBS Handbook 91, ch 20 (1963).

[19] Mather, B., Cement Performance in Concrete, Technical Report No. 6-787, U.S. Army Engineer Waterways Experiment Station, Corps of Engineers, Vicksburg, Miss., Sept. 1967.

[20] Portland Cement Association Research and Development Laboratories, Bulletins 26, 30, 32, 38, 43, $60,89,102,114$ by various authors.

[21] Powers, T. C., and Brownyard, T. L., Bulletin 20, Research Laboratories of the Portland Cement Association (1948). 



\title{
Section 10. Shrinkage and Expansion of Concrete
}

\author{
R. L. Blaine and H. T. Arni
}

The relationship between the cement characteristics and the drying shrinkages of concretes made of a large number of cements of different types and compositions, as well as the subsequent expansions when the concretes were rewetted, were studied by fitting multivariable regression equations with the aid of a digital computer. Specimens $6 \times 8 \times 16$ inches, were made using 5.5 bags of cement (nominal) per cubic yard with a water/cement ratio of 0.635 , as well as with a slump of $5 \pm 1$ inches. Increases in $\mathrm{C}_{3} \mathrm{~A}$, $\mathrm{C}_{4} \mathrm{AF}$, fineness of the cement, and air content of the concrete were associated with increases in both shrinkage on drying and expansion on rewetting of the concretes. Increases in $\mathrm{Na}_{2} \mathrm{O}, \mathrm{SO}_{3}$, and ignition loss of the cements were associated with decreases in the shrinkage values of the concretes. None of the individual trace elements, except possibly $\mathrm{Rb}$ and $\mathrm{SrO}$, were associated to a highly significant degree with shrinkage or expansion characteristics of the concretes. The use of trace elements in equations with other more commonly determined variables resulted in a significant reduction in variance. There was no relationship between the shrinkage of concrete specimens moist cured 14 days and then dried in laboratory air for eight weeks, and the shrinkage of neat cements, moist cured only 24 hours and then dried in laboratory air. Higher values for dynamic Young's modulus of elasticity of the concretes were associated with lower shrinkage and expansion values.

Key Words: Cement composition; expansion-shrinkage ratios; portland cement concrete; shrinkage of concrete; trace elements.

\section{CONTENTS}

1. Introduction

2. Materials

2.1. Cements

3. Methods of test_......... 38

3.1. Preparation of concretes

3.2. Test specimens

3.3. Storage of specimens

3.4. Shrinkage and expansion measurements _. _. 39

3.5. Weight loss and gain

4. Abbreviations _..... 40

5. Statistical analyses........ 40

6. Results of tests

6.1. Cement content of concretes

6.2. Drying shrinkage of concretes_.......... 42

a. Drying shrinkage of series $\mathrm{O}$ concretes having a water/cement ratio of 0.635 (OSHR)

b. Drying shrinkage of series A concretes having a $5 \pm 1 \mathrm{in}$. slump (ASHR)

6.3. Expansion of concretes as a result of rewetting

a. Expansion of series O concretes made with a water/cement ratio of 0.635 , air dried, and then rewetted (OEXP) ............

b. Expansion of series A concretes made with a slump of $5 \pm 1 \mathrm{in}$., air-dried and then rewetted (AEXP)

6.4. Residual shrinkage or difference between the percentage shrinkage during drying and the percentage expansion with subsequent rewetting -

a. Residual shrinkage of series 0 concretes made with a water/cement ratio of 0.635 (ODSX)

ge

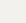

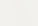

(1)

8

9

0

b. Residual shrinkage of series A concretes made having a slump of $5 \pm 1 \mathrm{in}$. (ADSX)

6.5. Ratio of percentage expansion divided by the percentage shrinkage

a. Ratio of expansion divided by the shrinkage of series $O$ concretes made with a water/cement ratio of 0.635 (OREX $=$ OEXP/OSHR)

b. Ratio of expansion divided by the shrinkage of concretes made having a slump of $5 \pm$ in. $(\mathrm{AREX}=\mathrm{AEXP} / \mathrm{ASHR})$

6.6. The ratio of the residual shrinkage after rewetting to the initial shrinkage (OREX and AREX) .

6.7. Shrinkage of tops and bottoms of concrete specimens as cast...................

7. Discussion

7.1. Comparison of equations for the dependent variables.

7.2. The effect of trace elements.

7.3. Agreement of duplicate determinations of percentage shrinkage and percentage expansion

7.4. Shrinkage and expansion of concrete versus shrinkage characteristics of neat cement.--

7.5. Shrinkage and expansion of concrete versus the dynamic Young's modulus of elasticity.

7.6. Top and bottom shrinkage and expansion.

7.7. Comparative test values on other hydraulic cements

8. Summary and conclusions

9. References 77

\section{Introduction}

As indicated in the previous section of this series of articles, there have been a great number of studies and articles published relative to the drying shrinkage of cement and concrete.
L'Hermite [1] ${ }^{1}$ has listed many of these, and has presented not only an excellent summary,

\footnotetext{
${ }^{1}$ Figures in brackets refer to literature references at the end of this section, p. 77 .
} 
but also theories on the relationships of the various types of volume change. There are many recognized variables that affect the drying shrinkage of concrete, including the water/ cement ratio and the kind of aggregates used, as well as the amount of curing or hydration of the cement prior to exposure of specimens to drying. Other variables may include the size and shape of the test specimens as well as the temperature and humidity at which they are dried.

L'Hermite has indicated [1] that different types of hydraulic cements may have quite different shrinkage characteristics, and that the influence of chemical composition of cement clinker on shrinkage and creep has not yet been studied. Swayze has indicated [2] that the effect of the type of cement on ultimate shrinkage of concrete is insignificant, but he did find considerable differences in shrinkage with both neat cements and mortars. The relationship, or lack of relationship, between the shrinkage of neat cement and the shrinkage of concrete has long been a matter of controversy. The differing observations of L'Hermite and Swayze appeared to justify a further study of this phenomenon. The previous section dealt with the variables which were associated with the shrinkage of neat cement paste; this section deals with the shrinkage of the concretes made with the same 199 portland cements.

Portland cement concretes that have been dried expand when rewetted but the amount of expansion is usually less than the original contraction. The variables associated with the expansion and the residual contraction of concretes have not been well established. Because of this lack of knowledge studies were also made of the expansion and the residual contraction of the concretes as well as various shrinkage-expansion ratios using the same specimens, employing the statistical procedures which have been used throughout this series of articles.

Because of the limited quantities of the different cements, it was not possible to study all of the known variables. The investigation was limited to the determination of the effects on shrinkage and expansion of the physical and chemical properties of the cements and the air contents of two series of concretes, one made with a constant water/cement ratio and the other with a $5 \pm 1$-in slump.

\section{Materials}

\subsection{Gements}

The cements used in this investigation have previously been described. The frequency distributions of the results of chemical analyses as well as spectrochemical analyses were reported in section 1 , part 1 of this series of articles [3]. Other tests with these cements have been reported in parts 2 and 3 of this series of articles [4] [5], and the variables as- sociated with the shrinkage characteristics of the neat portland cement pastes were presented in the previous section (see page 1). Most of the 199 commercial portland cement were obtained from different areas of the United States, but a few were from other countries. The cements were classified as to type, principally on the basis of chemical and physical properties ${ }^{2}$.

\section{Methods of Test}

\subsection{Preparation of Concretes}

The details of the proportioning and mixing of the concretes were described in part 1 , section 1 of this series of articles [3].

Two series of concretes were made with these cements. One series, (Series 0), was made with a constant water/cement ratio $(\mathrm{w} / \mathrm{c})$ of 0.635 . A second series, (Series A), was made in which the water was varied, if necessary, to obtain a concrete with a $5 \pm 1$-in slump. In both series, the cement-to-aggregate weight ratio was constant. The quantities of cement and aggregate per unit volume of concrete varied to some extent from the nominal $51 / 2$ bags of cement per cubic yard as designed, primarily because of variations of the entrained and entrapped air. The variations of the cement content will be reported in a later subsection. The mixing and placing of the concretes were performed at $73^{\circ} \mathrm{F}$.

\subsection{Test Specimens}

The $6 \times 8 \times 16$-in concrete blocks used for the shrinkage and expansion measurements are shown in figure 10-1. They were cast in plasticlined, paraffined-hardwood molds. The sides and bottoms of the molds were bolted together using heavy graphite grease in all joints to prevent leakage or loss of water. No oil or grease was used on the plastic liner. Metal frames fastened to the molds were used to hold the gage points $(5 / 16 \times 11 / 2$-in phosphor-bronze bolts) in position, $10 \mathrm{in}$, center to center, in

\footnotetext{
${ }^{2}$ On the basis of this classification there were 82 Type I, 8 Type IA, 68 Type II, 3 Type IIA, 20 Type III, 3 Type IIIA, 3 Type IV. and 12 Type $\dot{V}$ cements.
} 

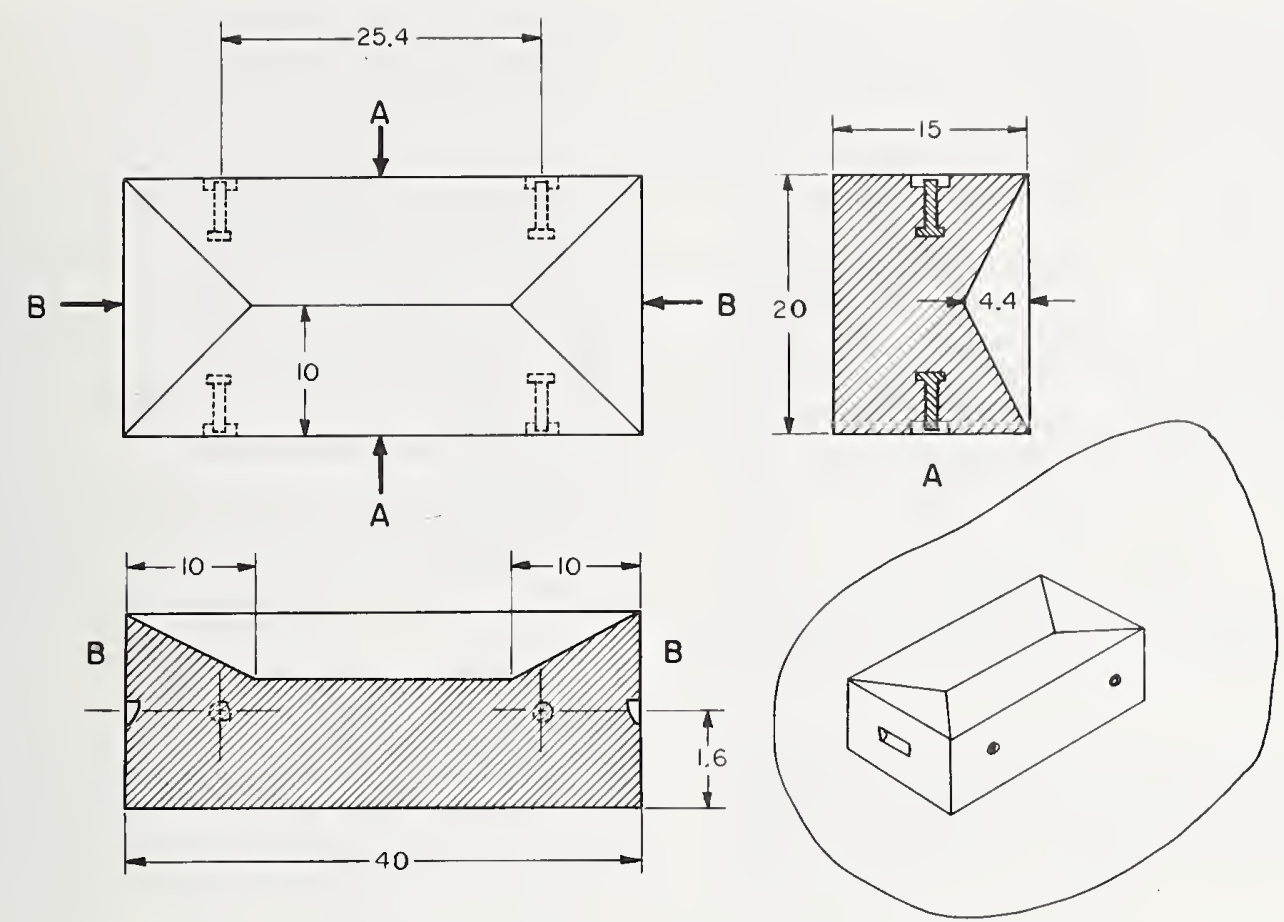

NOTE: ALL DIMENSIONS IN CENTIMETERS

FIGURE 10-1. Design and dimensions of specimen used for determining shrinkage and expansion values of concretes made from different cements.

(The purpose of the depression in the one side was to retain water and ice when specimens were placed with this side up in later outdoor exposure tests).

the top and bottom of the concrete block as cast until the molds could be stripped. (The concrete blocks were made for outdoor exposure tests after completion of the laboratory measurements, and the purpose of the 2 -in depression in the one side was to hold rain, melted snow, and ice in the weathering test).

Two specimens were made from each of the cements, one of each of the two series of concrete, the one with a water/cement ratio of 0.635 and the other with a $5 \pm 1$-in slump. Each specimen was cast with a $6 \times 16$-in side as a base. The 8-in depth of concrete was placed in three layers, and each layer was tamped 25 times with a $5 / 8$-in diameter bullet-nosed tamping rod. The sides of the mold were spaded after each layer, and the mold was tapped vigorously to remove entrapped air.

\subsection{Storage of Specimens}

The concrete specimens remained in the molds covered with wet burlap for the first 24 hr. After stripping the molds, drilling the gage holes, and making length and weight measurements, the specimens were placed in a fog room at 100 percent relative humidity for 13 days. The concrete specimens were then placed on end with five sides exposed to laboratory air at $73^{\circ} \mathrm{F}$ and $50 \pm 5$-percent relative humidity for 8 weeks. They were then immersed in water at $73{ }^{\circ} \mathrm{F}$ for 4 weeks.

\subsection{Shrinkage and Expansion Measurements}

The gage holes were drilled in the phosphorbronze bolts after the molds were stripped at about $24 \mathrm{hr}$. A 10 -in gage-length Whittemoretype strain gage together with an invar-steel reference bar was used to measure changes in the distances between the gage holes in both the tops of the specimens as cast as well as the gage holes in the bottoms of specimens as cast. The first measurements were made as soon as possible after removal from the molds. Measurements were also made after the concrete specimens had been stored as indicated in par. 3.3. The length changes as determined by means of the Whittemore gage were multiplied by 10 to arrive at values for percentage length change.

The percentage shrinkage was calculated from the difference between the measurements made after storage in the fog room and those made after the additional 8 weeks in laboratory air. The calculated values for percentage shrinkage will generally be referred to simply as shrinkage or shrinkage values. The percent- 
age expansion was calculated from the differences between the measurements made after the 8 weeks in laboratory air and those made after the subsequent 4 weeks in water. The calculated values for percentage expansion will generally be referred to simply as expansion or expansion values.

The averages of the top and bottom measurements were used in calculating the shrinkage and expansion value unless otherwise stated. The values reported were for a single specimen except for those cements where the use of a $\mathrm{w} / \mathrm{c}$ of 0.635 resulted in a slump of $5 \pm 1 \mathrm{in}$, in which case the average of the two specimens was used.

\subsection{Weight Loss and Gain}

At the times that length measurements were made, the specimens were also weighed. The percentage weight loss was calculated from the weight after the moist-air storage and the weight after the 8-week drying in laboratory air. The percentage weight-gain was calculated from the weight of the specimen after drying in laboratory air for 8 weeks and the weight after the subsequent 4 weeks in water.

It was noted that there was generally a slight weight gain (and also expansion) of the specimens in the 13 days of moist-air storage. This gain may have occurred because of inadequate moist curing during the first $24 \mathrm{hr}$, or because of loss of weight during the period after the molds were stripped and the gage holes drilled and initial measurements made and before the specimens were placed in the fog room.

\section{Abbreviations}

The abbreviations, notations, etc. used in this section for chemical and physical properties are the same as those used in previous sections of this series of articles ${ }^{3}$.

In this section, the prefix " $O$ " of the fourletter titles for the various dependent variables refers to the concretes of Series $\mathrm{O}$ in which a water/cement ratio of 0.635 was used. The prefix "A" refers to the concretes of Series A which had a $5 \pm 1$-in slump. A summary of the abbreviations for the dependent variables used in this section are as follows:

For Series O concretes made with a water/ cement ratio of 0.635 :

OSHR $=$ percentage shrinkage after 56 days drying in laboratory air following 14 days curing in a fog room.
OEXP $=$ percentage expansion after 28 days water storage following the 14 days moist-air curing and 56 days drying in laboratory air.

ODSX $=$ OSHR minus OEXP $=$ residual shrinkage.

OREX = OEXP/OSHR.

OEXR $=($ OSHR minus OEXP) $/$ OSHR $)=$ ODSX/OSHR.

ODSH $=$ percentage shrinkage of the top of the specimen as cast minus the percentage shrinkage of the bottom as cast.

For Series A concretes having a $5 \pm 1$-in slump the letter " $A$ " is used instead of " $O$ " as ASHR, AEXP, ADSX, AREX, AEXR, and $\mathrm{ADSH}$ for the dependent variables.

\section{Statistical Analyses}

The statistical techniques used to find and evaluate the independent variables associated with the shrinkage, expansion, the differences, and the ratios, have been described in a previous section of this series on "Materials and Techniques" [3]. The statistical treatment was the same as that used in all previous sections of this series of articles. Multiple regression equations were calculated by a least-squares method using various independent variables to determine which showed an association with each of the dependent variables. As in previous sections equations were calculated for both the $\mathrm{AE}+\mathrm{NAE}$ cements and the NAE cements. Calculations were made using only commonly determined variables and also using these to-

\footnotetext{
${ }^{3}$ These abbreviations include the use of $\mathrm{C}_{3} \mathrm{~A}, \mathrm{C}_{3} \mathrm{~S}, \mathrm{C}_{2} \mathrm{~S}$, and $\mathrm{C}_{4} \mathrm{AF}$ for the calculated potential compounds, tricalcium aluminate, tricalcium silicate, dicalcium silicate, and tetracalcium aluminoferrite, respectively. Also used are Insol for insoluble residue, Loss for loss on ignition, APF for air permeability fineness, Wagn for Wagner Turbidimeter fineness. AE + NAE refers to air-entraining plus non-air-entraining cements, and NAE to the non-air-entraining plus non-ai
}

gether with minor and trace elements.

Ratios of reduction in variance to original variance (" $F$ " ratios) obtained by fitting equations were calculated for two kinds of cases: (1) for equations including a few main independent variables as compared to the original data on the dependent variables, or (2) for equations in which additional independent variables were included as compared to a previous equation with fewer variables ${ }^{4}$. The calculated "F" ratios and critical "F" values which must be equalled or exceeded for significance at the

\footnotetext{
4 Statistical terms and notations employed in this section are the same as those used in previous sections of this series of articles. For example, S.D. refers to the estimated standard deviation calculated from the residuals of a fitted equation, or the estimated standard deviation about the average. Also, as in previous secstandard deviation about the average. Also, as in previous sec-
tions, s.d. refers to the estimated standard deviation of a coefficient of an independent variable used in a fitted equation. The term coef./s.d. is the ratio of the estimated coefficient (of an independent variable used in an equation) to its estimated standard deviation. " $F$ "' designates Fisher's ratio of variances and D. F is used to designate the number of degrees of freedom. As indicated in previous sections, a coef./s.d. ratio greater than one was considered to be of sufficient significance to warrant further investigation.
} 
$a=0.05$ and $a=0.01$ probability levels are summarized in a table (table 10-44).

After equations had been developed in which independent variables were significantly associated with the dependent variables, the residuals of these equations were fitted by a leastsquares method to other single independent variables and the reduction in variance calculated. If any of the additional independent variables indicated a significant reduction in variance, they were tried in the equation and retained if the coef./s.d. ratio was greater than 1 .

Equations were also computed for the "odds" and "evens" in the array of cements. Comparisons were made of the coefficients of the variables in the two groups of data, and these were compared to the coefficients and coef./s.d. ratios computed for all the cements.

Although shrinkage and expansion measurements were made on all 199 cements, the calculations of the equations presented in this section were limited to those for which traceelement determinations had been made. The calculated relationships of the shrinkage and expansion of the concretes to the dynamic mod- ulus of $3 \times 4 \times 16$-in concrete specimens, or to the shrinkage and cracking characteristics of neat cement pastes, included all the cements for which values were available except the three white cements and the cement having a high autoclave expansion. A few other cements that had large deviations from the calculated relationships, for no apparent reason, were also excluded.

Equations presented in this article were selected from a large number of trial equations indicating the calculated relationship of various independent variables to the shrinkage and expansion values, their differences, and their ratios 5. A summary of the relationships indicated by the equations for both series of concretes will be given in the discussion in subsection 7 .

Some of the limitations on interpretations of multivariable regression equations as well as other statistical techniques used in this series of articles have been discussed in section 1, subsections 4.2., 4.3., and 5 [3]. Other limitations and problems of interpretation have also been discussed in other subsections of this series of articles.

\section{Results of Tests}

\subsection{Cement Content of Concretes}

The frequency distribution of the cements with respect to the cement content of the Series $\mathrm{O}$ concretes made with a water/cement ratio of 0.635 is presented in table $10-1$. In table $10-2$ is presented similar information with respect to the Series A concretes made with a slump of $5 \pm 1 \mathrm{in}$. It is apparent, from these tables, that concretes made with the air-entraining cements had cement contents considerably lower than the originally designed mix. The cement contents were also, in most instances, lower than those of the concretes made with the non-airentraining cements. The possible effects of differences of cement content on shrinkage and expansion will be discussed in a later subsection. The subject is introduced at this time in view of the fact that cement content may be a variable which must be considered in the analyses of the results of shrinkage and expansion measurements made on these concrete specimens. With a fixed cement to aggregate weight ratio, the entrained and entrapped air affected the weight per cubic foot of the freshly mixed concrete. The air content also affected the calculated cement factor. Of the two related variables (air content and cement factor), the air content was used as one of the independent variables in equations relating various independent variables to each of the dependent variables.

\footnotetext{
5 These equations were selected primarily to indicate the association with commonly determined independent variables having coef./ s.d. ratios greater than one when used in multivariable equations, and also to indicate which of minor and trace elements may have an effect.
}

TABLE 10-1. Frequency distribution of cements with respect to cement content, in bags per cubic yard, of concretes made with a watercement ratio of 0.635

\begin{tabular}{|c|c|c|c|c|c|c|c|c|c|c|c|c|c|c|}
\hline \multirow{3}{*}{ Type cement } & \multicolumn{13}{|c|}{ Cement content, bags per cubic yard of concrete } & \multirow{3}{*}{ Total } \\
\hline & $\begin{array}{c}4.90 \\
\text { to } \\
4.95\end{array}$ & $\begin{array}{c}4.95 \\
\text { to } \\
5.00\end{array}$ & $\begin{array}{c}5.00 \\
\text { to } \\
5.05\end{array}$ & $\begin{array}{c}5.05 \\
\text { to } \\
5.10\end{array}$ & $\begin{array}{c}5.10 \\
\text { to } \\
5.15\end{array}$ & $\begin{array}{c}5.15 \\
\text { to } \\
5.20\end{array}$ & $\begin{array}{c}5.20 \\
\text { to } \\
5.25\end{array}$ & $\begin{array}{c}5.25 \\
\text { to } \\
5.30\end{array}$ & $\begin{array}{c}5.30 \\
\text { to } \\
5.35\end{array}$ & $\begin{array}{c}5.35 \\
\text { to } \\
5.40\end{array}$ & $\begin{array}{c}5.40 \\
\text { to } \\
5.45\end{array}$ & $\begin{array}{c}5.45 \\
\text { to } \\
5.50\end{array}$ & $\begin{array}{c}5.50 \\
\text { to } \\
5.55\end{array}$ & \\
\hline & \multicolumn{13}{|c|}{ Number of cements } & \\
\hline 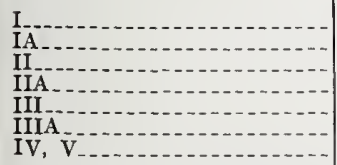 & 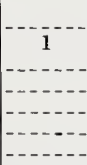 & 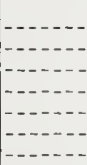 & 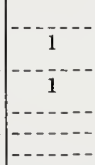 & 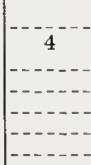 & $\mid \begin{array}{c}2^{-} \\
-y^{2} \\
-\cdots\end{array}$ & 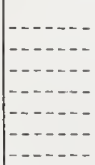 & $\frac{1}{-1-1}-1$ & 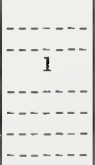 & 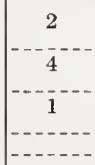 & $\frac{20}{-}-\frac{-}{5}$ & $\begin{array}{c}38 \\
18 \\
10\end{array}$ & $\begin{array}{c}21 \\
-39 \\
-\frac{7}{5}\end{array}$ & $\mid$\begin{tabular}{c}
1 \\
1 \\
\hdashline-1 \\
\hdashline-1
\end{tabular} & $\begin{array}{r}82 \\
8 \\
68 \\
3 \\
20 \\
3 \\
15\end{array}$ \\
\hline Total & 1 & 0 & 2 & 4 & 5 & 0 & 2 & 1 & 7 & 29 & 74 & 72 & 2 & 199 \\
\hline
\end{tabular}




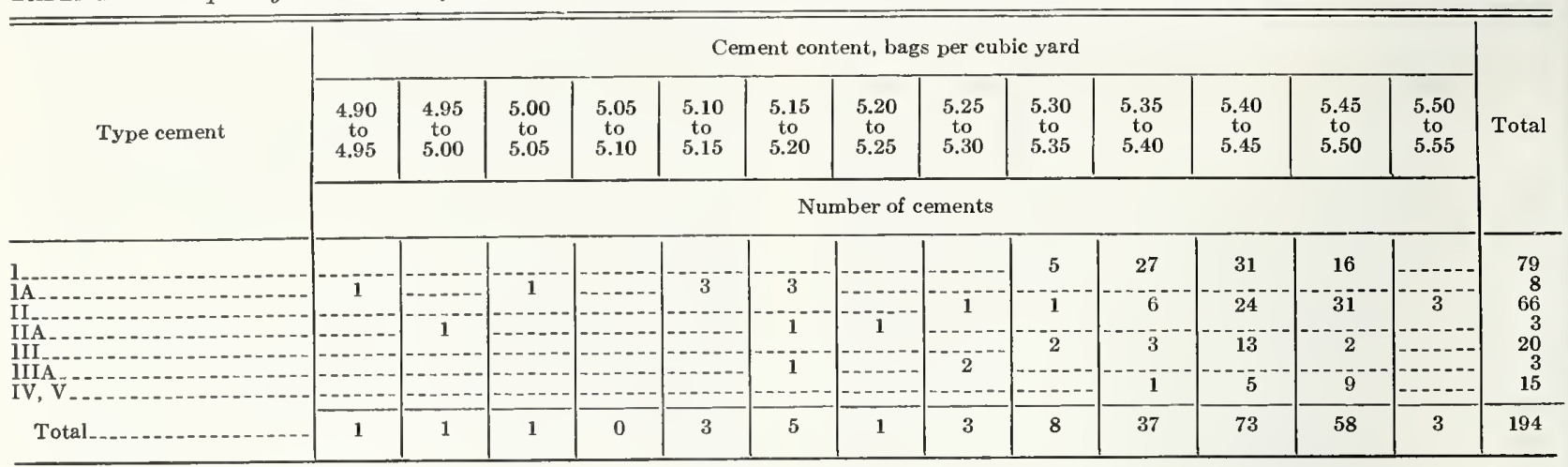

\subsection{Drying Shrinkage of Concretes}

a. Drying Shrinkage of Series $O$ Concretes having a water/cement ratio of 0.635 (OSHR)

The frequency distributions of the cements of the different types with respect to shrinkage of the Series $\mathrm{O}$ concretes are presented in table 10-3. The concretes were all made with a water/cement ratio of 0.635 , moist cured for 14 days, and then placed in laboratory air for 56 days. The concretes made of the air-entraining cements generally had greater shrinkage values than the overall average of 0.030 . There was a fairly broad distribution of values and an overlapping of the values for concretes made of the different types of NAE cements. The values for the $\mathrm{AE}$ cements also overlapped the values for the NAE cements.

Equations relating the shrinkage of the Series $\mathrm{O}$ concrete specimens made of $\mathrm{AE}+\mathrm{NAE}$ cements to various independent variables are presented in table 10-4. Equation 1 indicates that there was a significant relationship between the shrinkage and the percentage weight loss after 56 days exposure to laboratory air. (See also table 10-44) ${ }^{6}$.

${ }^{\circ} \mathrm{Eq} 0$ as used in table 10-44 refers to the S.D. value of the corresponding dependent variable as indicated in footnotes in the tables of equations.
A number of commonly determined variables were found to have coef./s.d. ratios greater than 1 when used in a multivariable equation. These are presented in eq 2 , and, by reference to table 10-44, it may be noted that a highly significant reduction in variance was attained. With the additional use of the trace elements $\mathrm{SrO}, \mathrm{Zn}$, and $\mathrm{Zr}$ in eq 3 there was a further significant reduction in the S.D. value. The equations calculated for the "odds" and "evens" in the array of cements (eqs $3 \mathrm{~A}$ and $3 \mathrm{~B}$ ) indicated that $\mathrm{C}_{3} \mathrm{~S}, \mathrm{Na}_{2} \mathrm{O}$, and $\mathrm{Zn}$ had coef./s.d. ratios less than 1 in one or the other of the smaller groups and that $\mathrm{Zr}$ had a reversal of the sign of the coefficient ${ }^{7}$.

With the use of $\mathrm{Al}_{2} \mathrm{O}_{3}$ and $\mathrm{Fe}_{2} \mathrm{O}_{3}$ in eq 4 instead of the potential compounds as in eqs 2 and 3 , a highly significant reduction in the S.D. value was also attained (see also table

${ }^{7}$ If a number of cements having higher than normal values for an independent variable are included in one of the two groups (the "odds" or "evens") by the arbitrary division of the cements, this distribution may result spurious coefficients for the variable. If the coefficients of both "odds" and "evens" of an independent variable are significant, a greater confidence can be placed in the equation, and in the association of that independent variable with the deand in the association of that independent variable with the de"odds" or "evens" is not greater than its s.d., some consideration may still be given to the larger groups of cements as indicating a possible relationship.

TABLE 10-3. Frequency distribution of the cements with respect to shrinkage of concretes made with a water-cement ratio of 0.635 moist-cured for 14 days, then dried in laboratory air for 56 days (OSHR)

\begin{tabular}{|c|c|c|c|c|c|c|c|c|c|c|c|}
\hline \multirow{3}{*}{ Type cement } & \multicolumn{10}{|c|}{ Percentage shrinkage } & \multirow{3}{*}{ Total } \\
\hline & $\begin{array}{c}0.014 \\
\text { to } \\
0.017\end{array}$ & $\begin{array}{c}0.017 \\
\text { to } \\
0.020\end{array}$ & $\begin{array}{c}0.020 \\
\text { to } \\
0.023\end{array}$ & $\begin{array}{c}0.023 \\
\text { to } \\
0.026\end{array}$ & $\begin{array}{c}0.026 \\
\text { to } \\
0.029\end{array}$ & $\begin{array}{c}0.029 \\
\text { to } \\
0.032\end{array}$ & $\begin{array}{c}0.032 \\
\text { to } \\
0.035\end{array}$ & $\begin{array}{c}0.035 \\
\text { to } \\
0.038\end{array}$ & $\begin{array}{c}0.038 \\
\text { to } \\
0.041\end{array}$ & $\begin{array}{c}0.041 \\
\text { to } \\
0.044\end{array}$ & \\
\hline & \multicolumn{10}{|c|}{ Number of cements } & \\
\hline 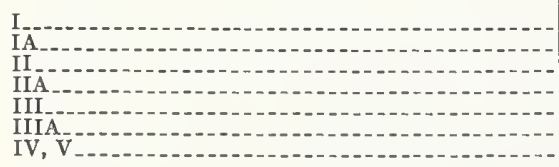 & 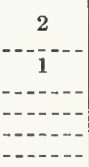 & \begin{tabular}{c}
2 \\
-1 \\
\hdashline 1 \\
\hdashline 1
\end{tabular} & $\begin{array}{l}2 \\
-1 \\
-2 \\
-2\end{array}$ & $\begin{array}{c}5 \\
-9 \\
-4 \\
-4\end{array}$ & $\begin{array}{l}11 \\
19 \\
-4 \\
-3\end{array}$ & $\begin{array}{r}23 \\
1 \\
11 \\
-1 \\
1 \\
1 \\
1\end{array}$ & $\frac{18}{13}$ & $\begin{array}{r}14 \\
4 \\
4 \\
2 \\
5 \\
1 \\
1\end{array}$ & \begin{tabular}{c}
5 \\
1 \\
4 \\
\hdashline 1 \\
\hdashline$-1-1$ \\
\hdashline-10
\end{tabular} & \begin{tabular}{c}
- \\
-2 \\
2 \\
-1 \\
\hdashline- \\
1 \\
2
\end{tabular} & $\begin{array}{r}82 \\
8 \\
68 \\
2 \\
20 \\
3 \\
15\end{array}$ \\
\hline Total & 3 & 4 & 10 & 20 & 37 & 38 & 37 & 31 & 11 & 7 & 198 \\
\hline
\end{tabular}


10-44). With the additional use of the trace elements $\mathrm{SrO}, \mathrm{Zr}$, and $\mathrm{Zn}$ in eq 5 there was a reduction in variance, significant at the 5-percent probability level. The coef./s.d. ratio for Zn was less than 1 in eq 5A for the "odds" in the array of cements and the coef. for $\mathrm{Zr}$ had a reversal of sign. The coefficients of neither were highly significant in eq 5 where all cements were included in the calculations.

Table 10-5 presents a corresponding series of equations for the shrinkage of Series O concretes made of the NAE cements. The air content did not have a coef./s.d. ratio greater than 1 in the equations calculated for these cements, but this variable was highly significant in the previous table where the $\mathrm{AE}$ cements were involved. The shrinkage was probably significantly related to the percentage weight loss of the concretes made of the different cements as indicated in eq 1 of table 10-5. The use of commonly determined independent variables in eqs 2 and 4 resulted in highly significant reductions in the S.D. values. The additional use of the trace elements $\mathrm{SrO}, \mathrm{Zr}$, and $\mathrm{Zn}$ in eqs 3 and 5 resulted in a possibly further reduction in the S.D. values (see also table $10-44$ ) significant at the 5-percent probability level. It may be noted that in equations for the "oda's" and "evens" (eqs $3 \mathrm{~A}, 3 \mathrm{~B}, 5 \mathrm{~A}$, and $5 \mathrm{~B}$ ) that $\mathrm{C}_{3} \mathrm{~S}, \mathrm{Fe}_{2} \mathrm{O}_{3}, \mathrm{SrO}$, $\mathrm{Zr}$, and $\mathrm{Zn}$ each had coef./s.d. ratios less than 1 in one or the other of the equations for the smaller groups of cements. The coefficients of these independent variables were generally not highly significant when the larger groups of cements were used in the calculations in eqs 3 and 5.

Coefficients of the independent variables in eq 3 of table 10-5 and the approximate ranges of these variables were used to determine their calculated contributions to the shrinkage of the constant w/c concretes, as well as the ranges of such contributions. These are presented in table $10-6^{8}$. These calculated values are estimates based on a single equation, and somewhat different values would be obtained by use of other equations.

It may be noted in tables 10-4, 10-5 and 10-6 that increases in $\mathrm{C}_{3} \mathrm{~A}, \mathrm{C}_{4} \mathrm{AF}$, and fineness of the cements were associated with increases in shrinkage values. Increases in $\mathrm{Na}_{2} \mathrm{O}, \mathrm{SO}_{3}$, and loss on ignition were associated with decreases in the shrinkage values. It is indicated in table 10-6 that differences in $\mathrm{C}_{3} \mathrm{~A}$, fineness, and $\mathrm{SO}_{3}$ show the greatest calculated effect on the shrinkage of the concretes. As previously indicated, the coefficient for the air content was highly significant when air-entraining cements

8 Corresponding tables for equations calculated for NAE cements, using the calculated potential compounds, other commonly determined variables, and trace elements having coef./s.d. ratios greater than 1 will be presented for other dependent variables. A summary table (table 10-45) is also presented for greater ease in comparing similar equations for AE + NAE cements. were included in the calculated equations as in table 10-4.

\section{b. Drying Shrinkage of Series A Concretes having a} $5 \pm 1$-in. Slump (ASHR)

The frequency distributions of the cements of the different types with respect to shrinkage of the Series A concretes (ASHR) are presented in table 10-7. There was a broad distribution of results and an overlapping of the cements of the different types. It was previously indicated in table $2-12$ of section 2 of this series of articles [3], that the air-entraining cements, Types IA, IIA, and IIIA, had slump values greater than $5 \pm 1$ in when made with a constant water/cement ratio. Although the water/cement ratio for these cements was reduced for the Series A concretes, most of these concretes were, as shown in table 10-3, in the upper half of the frequency distribution.

The frequency distribution of the water/ cement ratios required for the Series A concretes was previously presented in table 2-17 in section 2 of this series of articles [3]. The $\mathrm{w} / \mathrm{c}$ ranged from about 0.55 to 0.70 .

Equations are presented in table 10-8 for $\mathrm{AE}+\mathrm{NAE}$ cements indicating the relationships between the shrinkage of the Series A concretes and the various independent variables. Equation 1 gives no significant indication of a relationship between the water/cement ratio required for the concretes with a $5 \pm 1-$ in slump and the shrinkage. There was a relationship, significant at the 5-percent probability level, between the shrinkage and the percentage weight-loss of the specimens of the different concretes. Using commonly determined independent variables in eqs 3 and 5 resulted in highly significant reductions in the S.D. values (see also table 10-44). The additional use of the trace elements $\mathrm{SrO}, \mathrm{Zr}$, and $\mathrm{Zn}$ in eq 4 or $\mathrm{Co}, \mathrm{SrO}$ and $\mathrm{Zn}$ in eq 6 resulted in reductions of the S.D. values, each significant at the 5-percent probability level. All of these trace elements had coef./s.d. ratios less than 1 in one or the other of the equations for the "odds" or "evens", eqs $4 \mathrm{~A}, 4 \mathrm{~B}, 6 \mathrm{~A}$, and 6B. The coef./s.d. for $\mathrm{C}_{3} \mathrm{~S}$ was also less than 1 in eq $4 \mathrm{~B}$.

Corresponding equations for the NAE cements are presented in table 10-9. The coef./ s.d. ratio for "air content" was less than 1 in equations for the NAE cements. The use of $\mathrm{w} / \mathrm{c}$ as an independent variable in eq 1 did not result in a significant reduction of variance. The use of commonly determined variables in eqs 3 and 5 resulted in highly significant reductions in the S.D. value. The additional use of trace elements $\mathrm{SrO}, \mathrm{Zr}$, and $\mathrm{Zn}$ in eq 4 or $\mathrm{Co}$, $\mathrm{Zr}$ and $\mathrm{Sn}$ in eq 6 resulted in a reduction of the S.D. value at the 5-percent probability level (see table 10-44). In equations for the "odds" and "evens" there were instances where each 
TABLE 10-4. Coefficients for equations for $A E+N A E$ cements relating OSHR, the percent nominal $51 / 2$ bags of cement per cubic yard and a water

\begin{tabular}{|c|c|c|c|c|c|c|c|}
\hline Equation & Note & & Const. & $\mathrm{C}_{3} \mathrm{~A}$ & $\mathrm{C}=\mathrm{S}$ & $\mathrm{C}_{4} \mathrm{AF}$ & $\mathrm{Al}_{2} \mathrm{O}_{3}$ \\
\hline 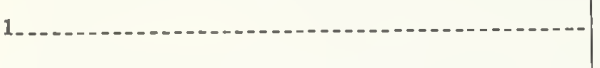 & (1) & $\begin{array}{l}\text { OSHR } \\
\text { s.d. }\end{array}$ & $\begin{array}{l}=+0.0208 \\
=(0.0028)\end{array}$ & & 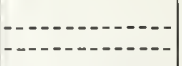 & --- & 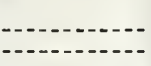 \\
\hline 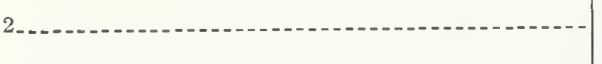 & (1) & $\begin{array}{l}\text { OSHR } \\
\text { s.d. }\end{array}$ & $\begin{array}{l}=+0.0130 \\
=(0.0040)\end{array}$ & $\begin{array}{c}+0.00136 \\
(0.00013)\end{array}$ & $\begin{array}{r}-0.0000765 \\
(0.0000529)\end{array}$ & +0.000926 & 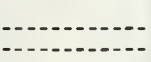 \\
\hline 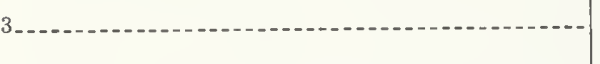 & (1) & $\begin{array}{l}\text { OSHR } \\
\text { s.d. }\end{array}$ & $\begin{array}{l}=+0.0139 \\
=(0.0039)\end{array}$ & $\begin{array}{c}+0.00123 \\
(0.00014)\end{array}$ & $\begin{array}{r}-0.0000835 \\
(0.0000517)\end{array}$ & $\begin{array}{r}+0.000898 \\
(0.000171)\end{array}$ & 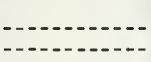 \\
\hline 3A_-1 & $\left({ }^{2}\right)$ & $\begin{array}{l}\text { OSHR (odd) } \\
\text { s.d. }\end{array}$ & $\begin{array}{l}=+0.0178 \\
=(0.0056)\end{array}$ & $\begin{array}{c}+0.00126 \\
(0.00020)\end{array}$ & $\begin{array}{r}-0.0001413 \\
(0.0000684)\end{array}$ & $\begin{array}{r}+0.000847 \\
(0.000241)\end{array}$ & 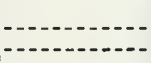 \\
\hline 3B & $\left({ }^{3}\right)$ & $\begin{array}{l}\text { OSHR (even) } \\
\text { s.d. }\end{array}$ & $\begin{array}{l}=+0.0076 \\
=\quad(0.0058)\end{array}$ & $\begin{array}{c}+0.00111 \\
(0.00022)\end{array}$ & $\begin{array}{r}*+0.0000746 \\
(0.0000890)\end{array}$ & $\begin{array}{r}+0.000998 \\
(0.000260)\end{array}$ & 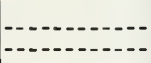 \\
\hline 4.-20.- & (1) & $\begin{array}{l}\text { OSHR } \\
\text { s.d. }\end{array}$ & $\begin{array}{l}=+0.0098 \\
=(0.0033)\end{array}$ & - & 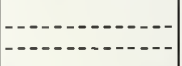 & 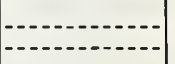 & $\begin{array}{r}+0.00358 \\
(0.00035)\end{array}$ \\
\hline $5 \ldots$ & $(1)$ & $\begin{array}{l}\text { OSHR } \\
\text { s.d. }\end{array}$ & $\begin{array}{l}=+0.0104 \\
=(0.0033)\end{array}$ & & & & $\begin{array}{r}+0.00323 \\
(0.00038)\end{array}$ \\
\hline - - - & (2) & $\begin{array}{l}\text { OSHR (odd) } \\
\text { s.d. }\end{array}$ & $\begin{array}{l}=+0.0114 \\
=(0.0048)\end{array}$ & & & & $\begin{array}{r}+0.00345 \\
(0.00055)\end{array}$ \\
\hline $5 B$ & $(3)$ & $\begin{array}{l}\text { OSHR (even) } \\
\text { s.d. }\end{array}$ & $\begin{array}{l}=+0.0100 \\
=(0.0050)\end{array}$ & -- & & 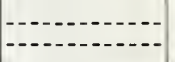 & $\begin{array}{r}+0.00307 \\
(0.00055)\end{array}$ \\
\hline
\end{tabular}

1177 cements; Avg=0.03028; S.D. =0.005832. $\quad 289$ cements. $\quad 388$ cements. $\quad$ * Coef./s.d. ratio less than 1.

TABLE 10-5. Coefficients for equations for NAE cements relating OSHR, the percentage $5 \frac{1}{2}$ bags of cement per cubic yard and a water-cem

\begin{tabular}{|c|c|c|c|c|c|c|c|}
\hline Equation & Note & & Const. & $\mathrm{C}_{3} \mathrm{~A}$ & $\mathrm{C}_{3} \mathrm{~S}$ & $\mathrm{C}_{4} \mathrm{AF}$ & $\mathrm{Al}_{2} \mathrm{O}_{3}$ \\
\hline $1 \ldots \ldots+\ldots$ & (1) & $\begin{array}{l}\text { OSHRR } \\
\text { s.d. }\end{array}$ & $\begin{array}{l}=+0.0214 \\
=(0.0028)\end{array}$ & & --- & -- & \\
\hline $2-\ldots+\ldots-n$ & (1) & $\begin{array}{l}\text { OSHR } \\
\text { s.d. }\end{array}$ & $\begin{array}{l}=+0.0157 \\
=(0.0040)\end{array}$ & $\begin{array}{c}+0.00135 \\
(0.00013)\end{array}$ & $\begin{array}{r}-0.0000775 \\
(0.0000534)\end{array}$ & $\begin{array}{r}+0.000866 \\
(0.000172)\end{array}$ & \\
\hline 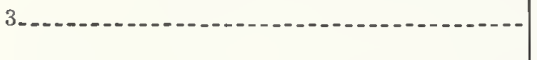 & (1) & $\begin{array}{l}\text { OSHR } \\
\text { s.d. }\end{array}$ & $\begin{array}{l}=+0.0164 \\
=(0.0040)\end{array}$ & $\begin{array}{r}+0.00123 \\
(0.00014)\end{array}$ & $\begin{array}{r}-0.0000860 \\
(0.0000522)\end{array}$ & $\begin{array}{r}+0.000846 \\
(0.000170)\end{array}$ & \\
\hline 3A & $(2)$ & $\begin{array}{l}\text { OSHR (odd) } \\
\text { s.d. }\end{array}$ & $\begin{array}{l}=+0.0159 \\
=(0.0055)\end{array}$ & $\begin{array}{r}+0.00124 \\
(0.00020)\end{array}$ & $\begin{array}{r}-0.0001790 \\
(0.0000638)\end{array}$ & $\begin{array}{c}+0.001023 \\
(0.000253)\end{array}$ & \\
\hline 3 B & $(3)$ & $\begin{array}{l}\text { OSHR (even) } \\
\text { s.d. }\end{array}$ & $\begin{array}{l}=+0.0143 \\
=(0.0058)\end{array}$ & $\begin{array}{r}+0.00105 \\
(0.00021)\end{array}$ & $\begin{array}{r}*+0.0000814 \\
(0.0000918)\end{array}$ & $\begin{array}{r}+0.000687 \\
(0.000233)\end{array}$ & \\
\hline $4+\ldots \ldots+n$ & (1) & $\begin{array}{l}\text { OSHR } \\
\text { s.d. }\end{array}$ & $\begin{array}{l}=+0.0123 \\
=(0.0034)\end{array}$ & $\begin{array}{ll}-2-2 \\
-2-2\end{array}$ & $\begin{array}{ll}-2-2 \\
-2-2\end{array}$ & 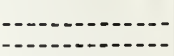 & $\begin{array}{c}+0.00354 \\
(0.00035)\end{array}$ \\
\hline 5........... & (1) & $\begin{array}{l}\text { OSHR } \\
\text { s.d. }\end{array}$ & $\begin{array}{l}=+0.0127 \\
=(0.0033)\end{array}$ & & & & $\begin{array}{c}+0.00323 \\
(0.00038)\end{array}$ \\
\hline 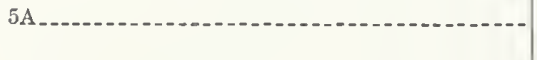 & $\left({ }^{2}\right)$ & $\begin{array}{l}\text { OSHR (odd) } \\
\text { s.d. }\end{array}$ & $\begin{array}{l}=+0.0076 \\
=(0.0049)\end{array}$ & & & & $\begin{array}{c}+0.00341 \\
(0.00055)\end{array}$ \\
\hline $5 B$ & $(3)$ & $\begin{array}{l}\text { OSHR (even) } \\
\text { s.d. }\end{array}$ & $\begin{array}{l}=+0.0170 \\
=(0.0049)\end{array}$ & & & & $\begin{array}{c}+0.00293 \\
(0.00054)\end{array}$ \\
\hline
\end{tabular}

1165 cements, Avg $=0.0297$ n percent; S.D. $=0.005636 . \quad 283$ cements. $\quad$ s 82 cements. $\quad$ * Coef./s.d. ratio less than 1. 
age shrinkage after 56 days drying following 14 days moist curing of concretes having a -cement ratio of 0.635 , to various independent variables

\begin{tabular}{|c|c|c|c|c|c|c|c|c|c|c|}
\hline $\mathrm{Fe}_{2} \mathrm{O}_{3}$ & $\mathrm{Na}_{2} \mathrm{O}$ & $\mathrm{SO}_{3}$ & Loss & $\mathrm{APF}$ & $\begin{array}{l}\text { Air } \\
\text { content }\end{array}$ & $\mathrm{Zr}_{\mathrm{r}}$ & $\mathrm{SrO}$ & $\mathrm{Zn}$ & $\begin{array}{l}\text { Percent } \\
\text { wt loss }\end{array}$ & S.D. \\
\hline & & & & & & $-\cdots$ & & & $\begin{array}{r}+0.00355 \\
(0.00106)\end{array}$ & 0.005668 \\
\hline & $\begin{array}{c}-0.00683 \\
(0.00192)\end{array}$ & $\begin{array}{c}-0.00853 \\
(0.00115)\end{array}$ & $\begin{array}{r}-0.00369 \\
(0.00065)\end{array}$ & $\begin{array}{r}+0.00000589 \\
(0.00000080)\end{array}$ & $\begin{array}{r}+0.00105 \\
(0.00018)\end{array}$ & & & & & $\begin{array}{r}0.004108 \\
-\end{array}$ \\
\hline & $\begin{array}{c}-0.00822 \\
(0.00198)\end{array}$ & $\begin{array}{r}-0.00894 \\
(0.00114)\end{array}$ & $\begin{array}{r}-0.00363 \\
(0.00065)\end{array}$ & $\begin{array}{c}+0.00000613 \\
(0.00000078)\end{array}$ & $\begin{array}{c}+0.00100 \\
(0.00018)\end{array}$ & $\begin{array}{c}+0.0126 \\
(0.0081)\end{array}$ & $\begin{array}{c}+0.00854 \\
(0.00407)\end{array}$ & $\begin{array}{c}-0.0198 \\
(0.0098)\end{array}$ & & 0.004005 \\
\hline & $\begin{array}{c}-0.01027 \\
(0.00246)\end{array}$ & $\begin{array}{c}-0.00961 \\
(0.00172)\end{array}$ & $\begin{array}{r}-0.00502 \\
(0.00121)\end{array}$ & $\begin{array}{r}+0.00000708 \\
(0.00000125)\end{array}$ & $\begin{array}{c}+0.00101 \\
(0.00024)\end{array}$ & $\begin{array}{r}-0.0679 \\
(0.0486)\end{array}$ & $\begin{array}{c}+0.00772 \\
(0.00616)\end{array}$ & $\begin{array}{r}*-0.0145 \\
(0.0199)\end{array}$ & & 0.003942 \\
\hline & $\begin{array}{r}*-0.00275 \\
(0.00361\end{array}$ & $\begin{array}{r}-0.00863 \\
(0.00164)\end{array}$ & $\begin{array}{c}-0.00317 \\
(0.00085)\end{array}$ & $\begin{array}{c}+0.00000510 \\
(0.00000107)\end{array}$ & $\begin{array}{r}+0.00108 \\
(0.00027)\end{array}$ & $\begin{array}{c}+0.0093 \\
(0.0090)\end{array}$ & $\begin{array}{r}+0.00860 \\
(0.00604)\end{array}$ & $\begin{array}{r}-0.0222 \\
(0.0119)\end{array}$ & & $\begin{array}{r}0.004106 \\
\ldots\end{array}$ \\
\hline $\begin{array}{c}+0.000702 \\
(0.000436)\end{array}$ & $\begin{array}{r}-0.00648 \\
(0.00191)\end{array}$ & $\begin{array}{c}-0.00836 \\
(0.00114)\end{array}$ & $\begin{array}{c}-0.00372 \\
(0.00065)\end{array}$ & $\begin{array}{r}+0.00000549 \\
(0.00000075)\end{array}$ & $\begin{array}{c}+0.00106 \\
(0.00018)\end{array}$ &..--- & & & & 0.004121 \\
\hline $\begin{array}{r}+0.000848 \\
(0.000429)\end{array}$ & $\begin{array}{r}-0.00783 \\
(0.00197)\end{array}$ & $\begin{array}{c}-0.00876 \\
(0.00114)\end{array}$ & $\begin{array}{r}-0.00365 \\
(0.00065)\end{array}$ & $\begin{array}{c}+0.00000568 \\
(0.00000074)\end{array}$ & $\begin{array}{r}+0.00102 \\
(0.00018)\end{array}$ & $\begin{array}{r}+0.0119 \\
(0.0081)\end{array}$ & $\begin{array}{r}+0.00857 \\
(0.00409)\end{array}$ & $\begin{array}{r}-0.0190 \\
(0.0099)\end{array}$ & & 0.004025 \\
\hline $\begin{array}{c}+0.000813 \\
(0.000616)\end{array}$ & $\begin{array}{r}-0.01008 \\
(0.00251)\end{array}$ & $\begin{array}{c}-0.00908 \\
(0.00174)\end{array}$ & $\begin{array}{c}-0.00537 \\
(0.00122)\end{array}$ & $\begin{array}{c}+0.00000632 \\
(0.00000123)\end{array}$ & $\begin{array}{c}+0.00101 \\
(0.00024)\end{array}$ & $\begin{array}{r}-0.0847 \\
(0.0490)\end{array}$ & $\begin{array}{r}+0.00671 \\
(0.00627)\end{array}$ & $\begin{array}{r}*-0.0112 \\
(0.0202)\end{array}$ & & 0.004022 \\
\hline $\begin{array}{r}+0.000988 \\
(0.000645)\end{array}$ & $\begin{array}{r}-0.00363 \\
(0.00345)\end{array}$ & $\begin{array}{c}-0.00864 \\
(0.00164)\end{array}$ & $\begin{array}{r}-0.00317 \\
(0.00085)\end{array}$ & $\begin{array}{r}+0.00000550 \\
(0.00000096)\end{array}$ & $\begin{array}{c}+0.00104 \\
(0.00027)\end{array}$ & $\begin{array}{c}+0.0103 \\
(0.0089)\end{array}$ & $\begin{array}{c}+0.00793 \\
(0.00600)\end{array}$ & $\begin{array}{r}-0.0221 \\
(0.0119)\end{array}$ & & 0.004100 \\
\hline
\end{tabular}

shrinkage after 56 days drying following 14 days moist curing of concretes having a nominal ent ratio of 0.635 , to various independent variables

\begin{tabular}{|c|c|c|c|c|c|c|c|c|c|}
\hline $\mathrm{Fe}_{2} \mathrm{O}_{3}$ & $\mathrm{Na}_{2} \mathrm{O}$ & $\mathrm{SO}_{3}$ & Loss & APF & $\mathrm{Zr}$ & $\mathrm{SrO}$ & $\mathrm{Zn}$ & $\begin{array}{l}\text { Percent } \\
\text { wt. loss }\end{array}$ & S.D. \\
\hline - & & & & & & & & $\begin{array}{r}+0.00283 \\
(0.00106)\end{array}$ & 0.005502 \\
\hline- & $\begin{array}{c}-0.00665 \\
(0.00190)\end{array}$ & $\begin{array}{r}-0.00874 \\
(0.00114)\end{array}$ & $\begin{array}{c}-0.00376 \\
(0.00065)\end{array}$ & $\begin{array}{r}+0.00000593 \\
(0.00000080)\end{array}$ & - & & & & $\begin{array}{r}0.004022 \\
-\end{array}$ \\
\hline 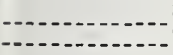 & $\begin{array}{r}-0.00795 \\
(0.00196)\end{array}$ & $\begin{array}{c}-0.00917 \\
(0.00113)\end{array}$ & $\begin{array}{c}-0.00367 \\
(0.00066)\end{array}$ & $\begin{array}{c}+0.00000619 \\
(0.00000078)\end{array}$ & $\begin{array}{c}+0.0118 \\
(0.0080)\end{array}$ & $\begin{array}{r}+0.00784 \\
(0.00414)\end{array}$ & $\begin{array}{r}-0.0209 \\
(0.0096)\end{array}$ & & $\begin{array}{r}0.003920 \\
-\end{array}$ \\
\hline 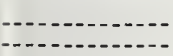 & $\begin{array}{c}-0.00906 \\
(0.00235)\end{array}$ & $\begin{array}{r}-0.00923 \\
(0.00164)\end{array}$ & $\begin{array}{c}-0.00484 \\
(0.00103)\end{array}$ & $\begin{array}{r}+0.00000778 \\
(0.00000128)\end{array}$ & $\begin{array}{c}+0.0441 \\
(0.0204)\end{array}$ & $\begin{array}{r}*+0.00312 \\
(0.00605)\end{array}$ & $\begin{array}{r}-0.0309 \\
(0.0116)\end{array}$ & & $\begin{array}{r}0.003732 \\
-0 .-0\end{array}$ \\
\hline 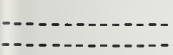 & $\begin{array}{c}-0.00393 \\
(0.00357)\end{array}$ & $\begin{array}{r}-0.00895 \\
(0.00167)\end{array}$ & $\begin{array}{c}-0.00344 \\
(0.00089)\end{array}$ & $\begin{array}{c}+0.00000610 \\
(0.00000105)\end{array}$ & $\begin{array}{c}*+0.0017 \\
(0.0093)\end{array}$ & $\begin{array}{c}+0.01367 \\
(0.00619)\end{array}$ & $\begin{array}{r}*-0.0129 \\
(0.0174)\end{array}$ & & $\begin{array}{r}0.004013 \\
-\end{array}$ \\
\hline $\begin{array}{c}+0.000558 \\
(0.000429)\end{array}$ & $\begin{array}{c}-0.00627 \\
(0.00189)\end{array}$ & $\begin{array}{c}-0.00856 \\
(0.00113)\end{array}$ & $\begin{array}{c}-0.00380 \\
(0.00065)\end{array}$ & $\begin{array}{r}+0.00000554 \\
(0.00000076)\end{array}$ & 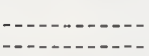 & 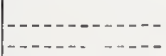 & $-\cdots$ & & 0.001034 \\
\hline $\begin{array}{c}+0.000710 \\
(0.000422)\end{array}$ & $\begin{array}{c}-0.00749 \\
(0.00195)\end{array}$ & $\begin{array}{r}-0.00896 \\
(0.00113)\end{array}$ & $\begin{array}{r}-0.00371 \\
(0.00066)\end{array}$ & $\begin{array}{r}+0.00000575 \\
(0.00000074)\end{array}$ & $\begin{array}{r}+0.0111 \\
(0.0080)\end{array}$ & $\begin{array}{c}+0.00704 \\
(0.00417)\end{array}$ & $\begin{array}{r}-0.0202 \\
(0.0097)\end{array}$ & & $\begin{array}{r}0.003941 \\
\end{array}$ \\
\hline $\begin{array}{r}+0.001365 \\
(0.000659)\end{array}$ & $\begin{array}{r}-0.00821 \\
(0.00243)\end{array}$ & $\begin{array}{r}-0.00875 \\
(0.00171)\end{array}$ & $\begin{array}{r}-0.00475 \\
(0.00108)\end{array}$ & $\begin{array}{r}+0.00000683 \\
(0.00000129)\end{array}$ & $\begin{array}{r}+0.0425 \\
(0.0214)\end{array}$ & $\begin{array}{r}*+0.00171 \\
(0.00631)\end{array}$ & $\begin{array}{r}-0.0285 \\
(0.0121)\end{array}$ & & $\begin{array}{r}0.003905 \\
-\end{array}$ \\
\hline $\begin{array}{r}*+0.000120 \\
(0.000569)\end{array}$ & $\begin{array}{c}-0.00453 \\
(0.00350)\end{array}$ & $\begin{array}{r}-0.00905 \\
(0.00166)\end{array}$ & $\begin{array}{c}-0.00334 \\
(0.00088)\end{array}$ & $\begin{array}{r}+0.00000502 \\
(0.00000094)\end{array}$ & $\begin{array}{r}*+0.0028 \\
(0.0092)\end{array}$ & $\begin{array}{c}+0.01266 \\
(0.00609)\end{array}$ & $\begin{array}{r}*-0.0140 \\
(0.0175)\end{array}$ & & $\begin{array}{r}0.004007 \\
-\end{array}$ \\
\hline
\end{tabular}


TABLE 10-6. Calculated contributions of independent variables to the percentage shrinkage after 56 days drying following 14 days moist curing of concretes having a nominal $51 / 2$ bags of cement per cubic yard and a water-cement ratio of 0.635 , and the calculated ranges of such contributions (OSHR)

\begin{tabular}{|c|c|c|c|c|}
\hline $\begin{array}{c}\text { Inde- } \\
\text { pendent } \\
\text { variables }\end{array}$ & $\begin{array}{l}\text { Range of } \\
\text { varíables } \\
\text { (percent) }\end{array}$ & $\begin{array}{l}\text { Coefficients } \\
\text { from eq }(3) \\
\text { table } 10-5\end{array}$ & $\begin{array}{l}\text { Calculater contri- } \\
\text { butions to OSHR }\end{array}$ & $\begin{array}{l}\text { Calculat- } \\
\text { ed ranges } \\
\text { of contri- } \\
\text { butions } \\
\text { to } \\
\text { OSHR }\end{array}$ \\
\hline 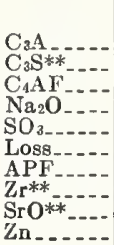 & $\begin{array}{c}0 \text { to } 15 \\
20 \text { to } 65 \\
4 \text { to } 17 \\
0 \text { to } 0.75 \\
1.2 \text { to } 3.0 \\
0.3 \text { to } 3.3 \\
* 2500 \text { to } 5500 \\
0 \text { to } 0.5 \\
0 \text { to } 0.4 \\
0 \text { to } 0.2\end{array}$ & $\begin{array}{l}+0.00123 \\
-0.000086 \\
+0.000846 \\
-0.00795 \\
-0.00917 \\
-0.00367 \\
+0.00000619 \\
+0.0118 \\
+0.00784 \\
-0.0209\end{array}$ & $\begin{array}{r}\text { Const. }=+0.0164 \\
0 \text { to }+0.0184 \\
-0.0017 \text { to }-0.0060 \\
+0.0034 \text { to }+0.0144 \\
0 \text { to }-0.0060 \\
-0.0110 \text { to }-0.0275 \\
-0.0011 \text { to }-0.0121 \\
+0.0155 \text { to }+0.0340 \\
0 \text { to }+0.0059 \\
0 \text { to }+0.0031 \\
0 \text { to }-0.0042\end{array}$ & $\begin{array}{l}0.0184 \\
0.0043 \\
0.0110 \\
0.0060 \\
0.0165 \\
0.0110 \\
0.0185 \\
0.0059 \\
0.0031 \\
0.0042\end{array}$ \\
\hline
\end{tabular}

* Coefinicient of doubtful significance as coef./s.d. ratio was less than 2

TABLE 10-7. Frequency distribution of the cements with respect to shrinkage of concrete having a nominal $51 / 2$ bags of cement per cubic yard and a $5 \pm 1$ in. slump, moist-cured for 14 days, then dried in laboratory air for 56 days $(A S H R)$

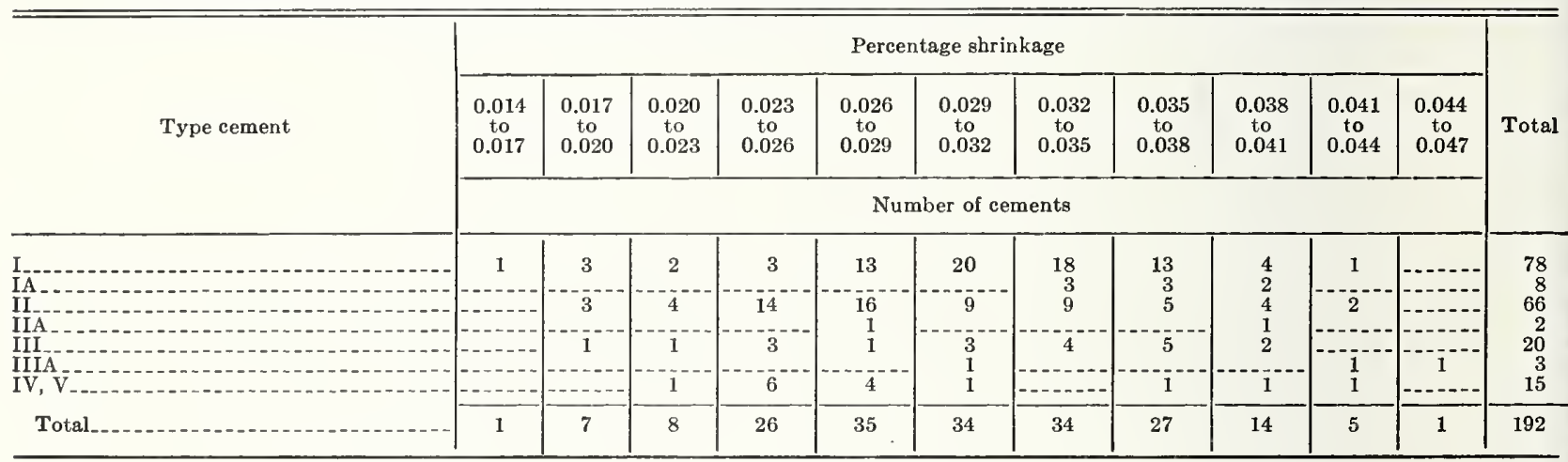

TABLE 10-8. Coefficients for equations for $A E+N A E$ cements relating $A S H R$, the percent nominal $51 / 2$ bags of cement per cubic yard and a

\begin{tabular}{|c|c|c|c|c|c|c|c|c|}
\hline Equation & Note & & Const & $\mathrm{C}_{3} \mathrm{~A}$ & $\mathrm{C}_{8} \mathrm{~S}$ & $\mathrm{C}_{4} \mathrm{AF}$ & $\mathrm{Al}_{2} \mathrm{O}_{3}$ & $\mathrm{Fe}_{2} \mathrm{O}_{3}$ \\
\hline 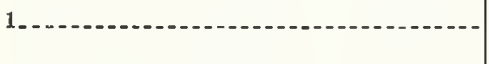 & (1) & $\begin{array}{l}\text { ASHR } \\
\text { s.d. }\end{array}$ & $\begin{array}{l}=+0.0363 \\
=(0.0113)\end{array}$ & 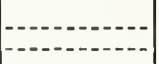 & 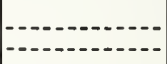 & 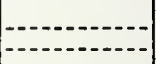 & 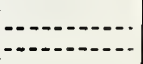 &.- \\
\hline 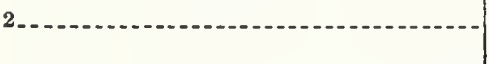 & (1) & $\begin{array}{l}\text { ASHR } \\
\text { s.d. }\end{array}$ & $\begin{array}{l}=+0.0218 \\
=(0.0029)\end{array}$ & 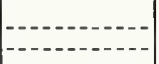 & 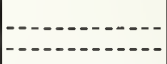 & 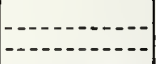 & & \\
\hline 3- 3 & (1) & $\begin{array}{l}\text { ASHR } \\
\text { s.d. }\end{array}$ & $\begin{array}{l}=+0.0118 \\
=(0.0040)\end{array}$ & $\begin{array}{c}+0.001358 \\
(0.000135)\end{array}$ & $\begin{array}{c}-0.0000835 \\
(0.0000535)\end{array}$ & $\begin{array}{c}+0.000942 \\
(0.000176)\end{array}$ & - & \\
\hline 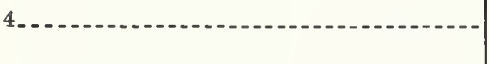 & (1) & $\begin{array}{l}\text { ASHR } \\
\text { s.d. }\end{array}$ & $\begin{array}{l}=+0.0129 \\
=(0.0040)\end{array}$ & $\begin{array}{c}+0.001221 \\
(0.000146)\end{array}$ & $\begin{array}{r}-0.0000903 \\
(0.0000524)\end{array}$ & $\begin{array}{c}+0.000918 \\
(0.000174)\end{array}$ & 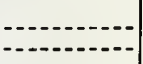 & \\
\hline $4 A_{\ldots} \ldots \ldots$ & $(2)$ & $\begin{array}{l}\text { ASHR (odd) } \\
\text { s.d. }\end{array}$ & $\begin{array}{l}=+0.0192 \\
=(0.0060)\end{array}$ & $\begin{array}{r}+0.001162 \\
(0.000206)\end{array}$ & $\begin{array}{r}-0.0001644 \\
(0.0000711)\end{array}$ & $\begin{array}{c}+0.000861 \\
(0.000264)\end{array}$ & --- & \\
\hline $4 B_{-\ldots} \ldots$ & $(8)$ & $\begin{array}{l}\text { ASHR (even) } \\
\text { s.d. }\end{array}$ & $\begin{array}{l}=+0.0046 \\
=(0.0058)\end{array}$ & $\begin{array}{c}+0.001159 \\
(0.000228)\end{array}$ & $\begin{array}{r}*+0.0000590 \\
(0.0000902)\end{array}$ & $\begin{array}{r}+0.000997 \\
(0.000243)\end{array}$ & $-\cdots$ & \\
\hline 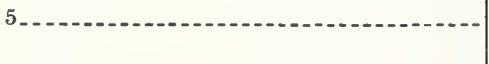 & (1) & $\begin{array}{l}\text { ASHR } \\
\text { s.d. }\end{array}$ & $\begin{array}{l}=+0.0083 \\
=(0.0034)\end{array}$ & 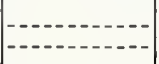 & 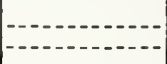 & - & $\begin{array}{c}+0.00357 \\
(0.00036)\end{array}$ & $\begin{array}{c}+0.000778 \\
(0.000441)\end{array}$ \\
\hline 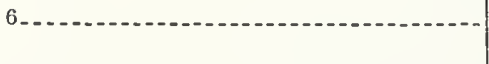 & (1) & $\begin{array}{l}\text { ASHR } \\
\text { s.d. }\end{array}$ & $\begin{array}{l}=+0.0099 \\
=(0.0033)\end{array}$ & 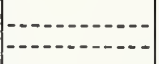 & $-\cdots-1$ & & $\begin{array}{c}+0.00315 \\
(0.00038)\end{array}$ & $\begin{array}{r}+0.000992 \\
(0.000436)\end{array}$ \\
\hline $6 A$ & $(2)$ & $\begin{array}{l}\text { ASHR (odd) } \\
\text { s.d. }\end{array}$ & $\begin{array}{l}=+0.0113 \\
=(0.0052)\end{array}$ & $-\cdots$ & - $-1-2-1$ & $-\cdots$ & $+\underset{(0.00056)}{0.00318}$ & $\begin{array}{r}+0.001077 \\
(0.000685)\end{array}$ \\
\hline $6 B_{-} \ldots \ldots$ & $(3)$ & $\begin{array}{l}\text { ASHR (even) } \\
\text { s.d. }\end{array}$ & $\begin{array}{l}=+0.0075 \\
=(0.0048)\end{array}$ & & - & - & $\begin{array}{c}+0.00310 \\
(0.00056)\end{array}$ & $\begin{array}{r}+0.001030 \\
(0.000593)\end{array}$ \\
\hline
\end{tabular}

1171 cements; $\mathrm{Avg}=0.03000$ percent; S.D. $=0.005648 . \quad 286$ cements. $\quad 385$ cements. $\quad$ * Cocf./8.d. ratio less than 1. 


\subsection{Expansion of Concretes as a Result of Rewetting}

a. Expansion of Series O Concretes made with a water/ cement ratio of 0.635 . Air-dried and then Rewetted (OEXP)

After 14 days moist-air curing, then drying in laboratory air for. 8 weeks, the concrete specimens were placed in water for 28 days. The frequency distribution of the expansion values of the Series $O$ concretes made of the different cements is presented in table 10-11. A comparison of table 10-11 for expansion and table 10-3 for shrinkage of the Series $O$ concretes shows that the range of values for the expansion was not so great as the range of values for the shrinkage. The expansion values of the air-entraining cements, were generally above the average for all cements in table 10-11 and the shrinkage values appeared to be still further above the average shrinkage for all cements in table 10-3. There was an overlapping of the expansion values of the cements of the different types in table 10-11.

Equations for AE + NAE cements are presented in table 10-12 indicating the relationship of the expansion values of Series $O$ concretes (OEXP) to various independent variables. Equation 1 indicates at the 5-percent significance level that there is a probable relationship between the expansion and the percentage weight-gain of the rewetted concrete specimens made of the different cements. The use of commonly determined independent variables in eqs 2 and 4 resulted in highly significant reduction in th S.D. values. (see also table 10-44). By the additional use of the trace elements, $\mathrm{P}, \mathrm{Pb}, \mathrm{Rb}, \mathrm{SrO}$ and $\mathrm{Zn}$ in eqs 3 and 5, a further significant reduction in the S.D. value was achieved. It may be noted that in equations for the "odds" and "evens", all of these trace elements except $\mathrm{Rb}$, had coef./s.d. ratios of less than 1 in one or the other of the equations for the smaller groups of cements, see eqs $3 \mathrm{~A}, 3 \mathrm{~B}$, $5 \mathrm{~A}$ and $5 \mathrm{~B}$.

A corresponding series of equations for the NAE cements is presented in table 10-13. The relationship of the expansion values to the percentage weight-gain resulting from soaking 28 days in water is presented in eq 1 . By reference to table 10-44 it may be noted that the indication of relationship is not significant at the 5 -percent probability level. The coef./s.d. ratio for the air content was less than 1 for the NAE cements, and this variable was not included in the equations. The use of commonly determined variables in eqs 2 and 4 resulted in highly significant reductions in the S.D. values. (see table 10-44). The use of trace elements $\mathrm{P}, \mathrm{Pb}$, $\mathrm{Rb}, \mathrm{SrO}$, and $\mathrm{Zn}$ in eqs 3 and 5 resulted in further significant reductions in the S.D. values. In the equations for the "odds" and "evens" (eqs $3 \mathrm{~A}, 3 \mathrm{~B}, 5 \mathrm{~A}$ and $5 \mathrm{~B}$ ) $\mathrm{Pb}$, and $\mathrm{SrO}$, as well as $\mathrm{CaO}$, had coef./s.d. ratios less than 1 in one or the other of the pairs of equations with the smaller groups of cements.

Calculated contributions of the different variables to the expansion after 28 days rewetting, as well as the estimated ranges of such contributions are presented in table 10-14. It may be noted that increases in fineness, $\mathrm{C}_{3} \mathrm{~A}, \mathrm{C}_{4} \mathrm{AF}, \mathrm{Rb}$, and possibly $\mathrm{P}$ were associated with increases in the expansion values. Increases in $\mathrm{SO}_{3}$ and

age shrinkage after 56 days drying following 14 days moist curing of concretes having a slump of $5 \pm 1$ in., to various independent variables

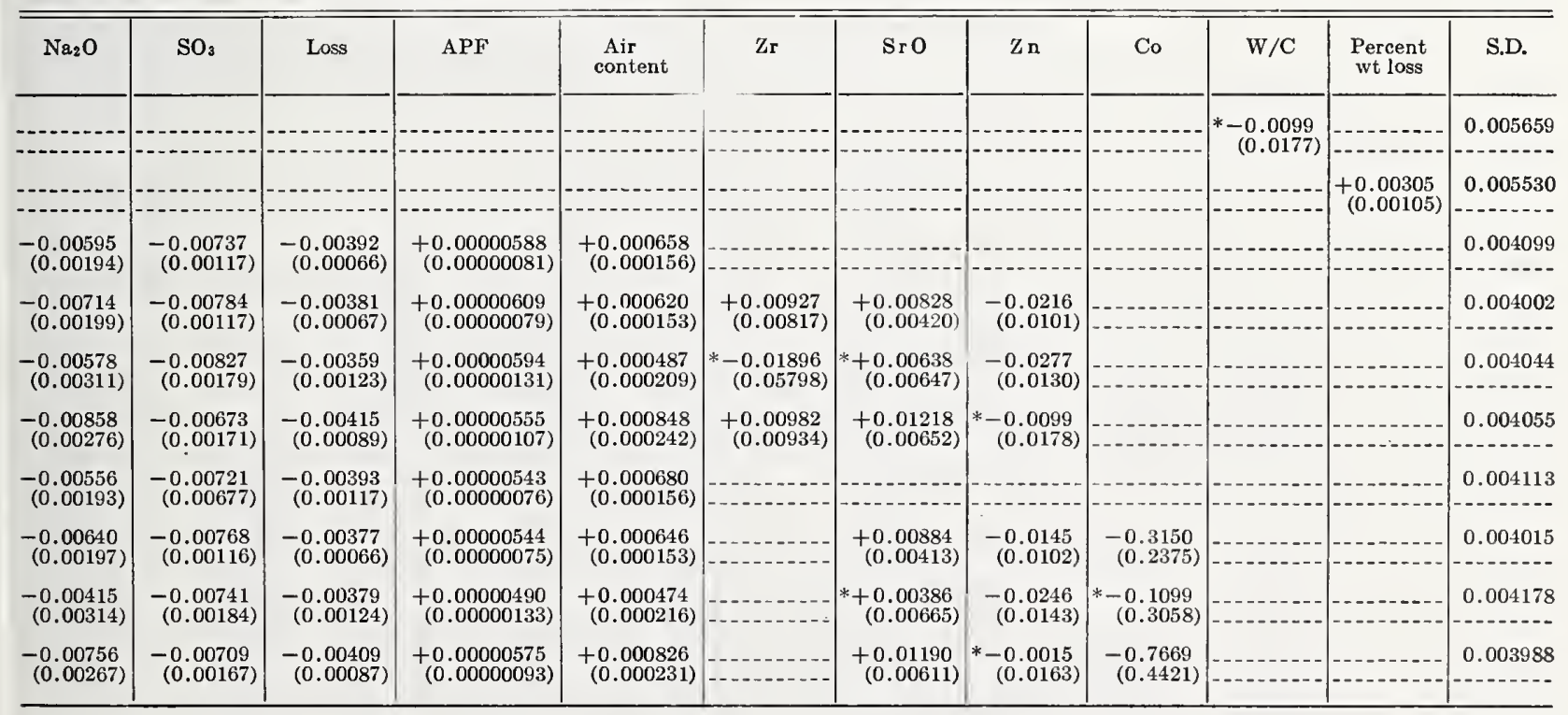


TABLE 10-9. Coefficients for equations for $N A E$ cements relating $A S H R$, the percentage $51 / 2$ bags of cement per cubic yard and a slump

\begin{tabular}{|c|c|c|c|c|c|c|c|}
\hline Equation & Note & & Const. & $\mathrm{C}_{3} \mathrm{~A}$ & $\mathrm{C}_{3} \mathrm{~S}$ & $\mathrm{C}_{4} \mathrm{AF}$ & $\mathrm{Al}_{2} \mathrm{O}_{3}$ \\
\hline 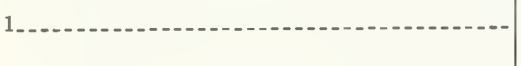 & (1) & $\begin{array}{l}\text { ASHR } \\
\text { s.d. }\end{array}$ & $\begin{array}{l}=-0.0017 \\
=(0.0149)\end{array}$ & - & --- & -1- & 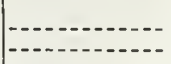 \\
\hline 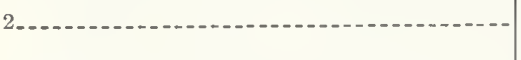 & (1) & $\begin{array}{l}\text { ASHR } \\
\text { s.d. }\end{array}$ & $\begin{array}{l}=+0.0193 \\
=\quad(0.0029)\end{array}$ & - & 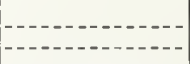 & 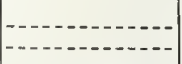 & 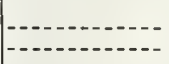 \\
\hline - & (1) & $\begin{array}{l}\text { ASHR } \\
\text { s.d. }\end{array}$ & $\begin{array}{l}=+0.0144 \\
=(0.0041)\end{array}$ & $\begin{array}{r}+0.001319 \\
(0.000134)\end{array}$ & $\begin{array}{r}-0.0000871 \\
(0.0000540)\end{array}$ & $\begin{array}{r}+0.000891 \\
(0.000174)\end{array}$ & 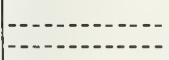 \\
\hline 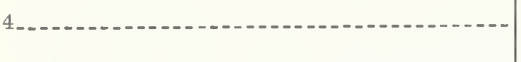 & (1) & $\begin{array}{l}\text { ASHR } \\
\text { s.d. }\end{array}$ & $\begin{array}{l}=+0.0152 \\
=\quad(0.0040)\end{array}$ & $\begin{array}{r}+0.001205 \\
(0.000145)\end{array}$ & $\begin{array}{c}-0.0000950 \\
(0.0000528)\end{array}$ & $\begin{array}{c}+0.000880 \\
(0.000172)\end{array}$ & 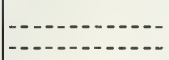 \\
\hline 4 A & (2) & $\begin{array}{l}\text { ASHR (odd) } \\
\text { s.d. }\end{array}$ & $\begin{array}{l}=+0.0158 \\
=(0.0065)\end{array}$ & $\begin{array}{c}+0.001212 \\
(0.000222)\end{array}$ & $\begin{array}{r}-0.0001852 \\
(0.0000775)\end{array}$ & $\begin{array}{c}+0.000916 \\
(0.000275)\end{array}$ & 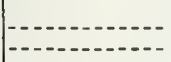 \\
\hline $4 \mathrm{~B}$ & (3) & $\begin{array}{l}\text { ASHR (even) } \\
\text { s.d. }\end{array}$ & $\begin{array}{l}=+0.0140 \\
=(0.0052)\end{array}$ & $\begin{array}{c}+0.001074 \\
(0.000202)\end{array}$ & $\begin{array}{r}*+0.0000337 \\
(0.0000816)\end{array}$ & $\begin{array}{c}+0.000800 \\
(0.000225)\end{array}$ & 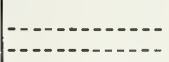 \\
\hline 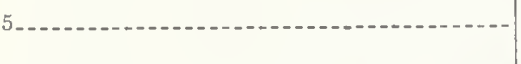 & (1) & $\begin{array}{l}\text { ASHR } \\
\text { s.d. }\end{array}$ & $\begin{array}{l}=+0.0106 \\
=(0.0024)\end{array}$ & 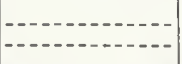 & --- & --- & $\begin{array}{r}+0.00346 \\
(0.00036)\end{array}$ \\
\hline 6 & (1) & $\begin{array}{l}\text { ASHR } \\
\text { s.d. }\end{array}$ & $\begin{array}{l}=+0.0120 \\
=(0.0034)\end{array}$ & & & & $\begin{array}{r}+0.00310 \\
(0.00038)\end{array}$ \\
\hline 6 A. & $(2)$ & $\begin{array}{l}\text { ASHR (odd) } \\
\text { s.d. }\end{array}$ & $\begin{array}{l}=+0.0094 \\
=(0.0055)\end{array}$ & & $-\cdots$ & 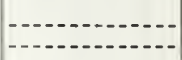 & $\begin{array}{r}+0.00316 \\
(0.00060)\end{array}$ \\
\hline - & (3) & $\begin{array}{l}\text { ASHR (even) } \\
\text { s.d. }\end{array}$ & $\begin{array}{l}=+0.0152 \\
=(0.0044)\end{array}$ & 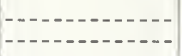 & 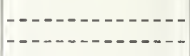 & 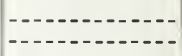 & $\begin{array}{r}+0.00291 \\
(0.00050)\end{array}$ \\
\hline
\end{tabular}

1159 cements: Avg $=0.02964$ percent; S.D. $=0.005558 .280$ cements.

TABLE 10-10. Calculated contributions of independent variables to the percentage shrinkage after 56 days drying following 14 days moist curing of concretes having a nominal $51 / 2$ bags of cement per cubic yard and a slump of $5 \pm 1 \mathrm{in}$, and the calculated ranges of such contributions $(A S H R)$

\begin{tabular}{|c|c|c|c|c|}
\hline $\begin{array}{l}\text { Inde- } \\
\text { pendent } \\
\text { variables }\end{array}$ & $\begin{array}{l}\text { Range of } \\
\text { variables } \\
\text { (percent) }\end{array}$ & $\begin{array}{l}\text { Coefficients } \\
\text { from eq }(4) \\
\text { table } 10-9\end{array}$ & $\begin{array}{l}\text { Calculated contri- } \\
\text { butions to ASHR }\end{array}$ & $\begin{array}{c}\text { Calculat- } \\
\text { ed ranges } \\
\text { of contri- } \\
\text { butions } \\
\text { to } \\
\text { ASHR }\end{array}$ \\
\hline 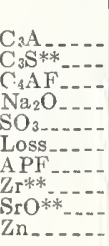 & $\begin{array}{r}0 \text { to } 15 \\
20 \text { to } 6.5 \\
4 \text { to } 17 \\
0 \text { to } 0.75 \\
1.2 \text { to } 3.0 \\
0.3 \text { to } 3.3 \\
* 2500 \text { to } 5500 \\
0 \text { to } 0.5 \\
0 \text { to } 0.4 \\
0 \text { to } 0.2\end{array}$ & $\begin{array}{l}+0.001205 \\
-0.0000950 \\
+0.00088 \\
-0.00687 \\
-0.00822 \\
-0.00389 \\
+0.00000617 \\
+0.00866 \\
+0.00681 \\
-0.0237\end{array}$ & $\begin{array}{r}\text { Const. }=+0.0152 \\
0 \text { to }+0.0181 \\
-0.0019 \text { to }-0.0062 \\
+0.0035 \text { to }+0.0150 \\
0 \text { to }-0.0051 \\
-0.0099 \text { to }-0.0247 \\
-0.0012 \text { to }-0.0128 \\
+0.0154 \text { to }+0.0339 \\
0 \text { to }+0.0043 \\
0 \text { to }+0.0027 \\
0 \text { to }-0.0047\end{array}$ & $\begin{array}{l}0.0181 \\
0.0043 \\
0.0115 \\
0.0051 \\
0.0148 \\
0.0116 \\
0.0185 \\
0.0043 \\
0.0027 \\
0.0017\end{array}$ \\
\hline
\end{tabular}

$* \mathrm{~cm}^{2} / \mathrm{g}$.

**Coeflicient of doubtful significance as coef./s.d. ratio was less than 2 .
379 cements. $*$ Coef./s.d. ratio less than 1 .

TABLE 10-11. Frequency distribution of cements with respect to expansion after 28 days moist storage following 56 days drying of nominal $51 / 2$ bags of cement per cubic yard concretes made with a water-cement ratio of 0.635 (OEXP)

\begin{tabular}{|c|c|c|c|c|c|c|c|c|c|}
\hline \multirow{3}{*}{ Type cement } & \multicolumn{8}{|c|}{ Percentage expansion } & \multirow{3}{*}{ Total } \\
\hline & $\left\{\begin{array}{l}0.011 \\
\text { to } \\
0.014\end{array}\right.$ & $\begin{array}{l}0.014 \\
\text { to } \\
0.017\end{array}$ & $\begin{array}{l}0.017 \\
\text { to } \\
0.020\end{array}$ & $\begin{array}{l}0.020 \\
\text { to } \\
0.023\end{array}$ & $\begin{array}{l}0.023 \\
\text { to } \\
0.026\end{array}$ & $\begin{array}{l}0.026 \\
\text { to } \\
0.029\end{array}$ & $\mid \begin{array}{c}0.029 \\
\text { to } \\
0.032\end{array}$ & $\left|\begin{array}{c}0.032 \\
\text { to } \\
0.035\end{array}\right|$ & \\
\hline & \multicolumn{8}{|c|}{ Number of cements } & \\
\hline-5 & 3 & 6 & 19 & 25 & 22 & 6 & 1 & & 82 \\
\hline & 1 & 13 & 19 & 20 & 11 & $\begin{array}{l}3 \\
2\end{array}$ & 1 & 1 & $\begin{array}{r}8 \\
68 \\
2\end{array}$ \\
\hline & - & 3 & 3 & 9 & 3 & 2 & - & 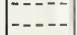 & 20 \\
\hline $\begin{array}{l}\text { III } \\
\text { IV }\end{array}$ & $\overline{1}^{-}$ & 3 & $\begin{array}{l}1 \\
6\end{array}$ & & $\overline{1}$ & $\begin{array}{l}1 \\
2\end{array}$ & 1 & & $\begin{array}{r}3 \\
15\end{array}$ \\
\hline Total_ & 5 & 25 & 48 & 59 & 41 & 16 & 3 & 1 & 198 \\
\hline
\end{tabular}

TABLE 10-12. Coefficients for equations for $A E+N A E$ cements relating $O E X P$, the ex $51 / 2$ bags of cement per cubic yard and a water-ce

\begin{tabular}{|c|c|c|c|c|c|c|c|}
\hline Equation & Note & & Const. & $\mathrm{C}_{3} \mathrm{~A}$ & $\mathrm{C}_{4} \Lambda \mathrm{F}$ & $\mathrm{CaO}$ & $\mathrm{Al}_{2} \mathrm{O}_{3}$ \\
\hline $1 \ldots$ & (1) & $\begin{array}{l}\text { oExp } \\
\text { s.d. }\end{array}$ & $\begin{array}{l}=+0.0164 \\
=\quad(0.0018)\end{array}$ & & & & \\
\hline $2 \ldots$ & (1) & $\begin{array}{l}\text { OEXP } \\
\text { s.d. }\end{array}$ & $\begin{array}{l}=+0.0098 \\
=(0.0023)\end{array}$ & $\begin{array}{c}+1.00066 .1 \\
(1.000090)\end{array}$ & $\begin{array}{r}+0.000413 \\
(0.000116)\end{array}$ & & \\
\hline $3 \ldots \ldots$ & (1) & $\begin{array}{l}\text { OEXP } \\
\text { s.d. }\end{array}$ & $\begin{array}{l}=+0.0107 \\
=(0.0022)\end{array}$ & $\begin{array}{r}+0.000595 \\
(0.000099)\end{array}$ & $\begin{array}{r}+0.000390 \\
(0.000115)\end{array}$ & & \\
\hline $3 A_{-. . .}$ & (2) & $\begin{array}{l}\text { OEXP (odd) } \\
\text { s.d. }\end{array}$ & $\begin{array}{l}=+0.0101 \\
=(0.0031)\end{array}$ & $\begin{array}{c}+0.000595 \\
(0.000136)\end{array}$ & $\begin{array}{c}+0.000390 \\
(0.000165)\end{array}$ & & \\
\hline 3B.- & $\left({ }^{2}\right)$ & $\begin{array}{l}\text { OEXP (even) } \\
\text { s.d. }\end{array}$ & $\begin{array}{l}=+0.0105 \\
=(0.0035)\end{array}$ & $\begin{array}{r}+0.000598 \\
(0.000152)\end{array}$ & $\begin{array}{c}+0.000427 \\
(0.000175)\end{array}$ & & \\
\hline $4 .-$. & (1) & $\begin{array}{l}\text { OEXP } \\
\text { s.d. }\end{array}$ & $\begin{array}{l}=+0.0394 \\
=(0.0123)\end{array}$ & - & 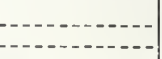 & $\begin{array}{r}-0.000453 \\
(0.000191)\end{array}$ & $\begin{array}{c}+0.00172 \\
(0.00023)\end{array}$ \\
\hline 5 & (1) & $\begin{array}{l}\text { OEXP } \\
\text { s.d. }\end{array}$ & $\begin{array}{l}=+0.0380 \\
=(0.0121)\end{array}$ & & & $\begin{array}{c}-0.000415 \\
(0.000188)\end{array}$ & $\begin{array}{r}+0.00155 \\
(0.00026)\end{array}$ \\
\hline $5 \mathrm{~A}_{--}$ & (2) & $\begin{array}{l}\text { OEXP (odd) } \\
\text { s.d. }\end{array}$ & $\begin{array}{l}=+0.0310 \\
=(0.0164)\end{array}$ & & & $\begin{array}{c}-0.000316 \\
(0.000255)\end{array}$ & $\begin{array}{c}+0.00157 \\
(0.00035)\end{array}$ \\
\hline $5 \mathrm{~B}_{\ldots} \ldots$ & (2) & $\begin{array}{l}\text { OEXP (even) } \\
\text { s.d. }\end{array}$ & $\begin{array}{l}=+0.0464 \\
=(0.0191)\end{array}$ & & & $\begin{array}{c}-0.000544 \\
(0.000295)\end{array}$ & $\begin{array}{c}+0.00153 \\
(0.00039)\end{array}$ \\
\hline
\end{tabular}

1176 cements; $A v g=0.02056$ percent; S.D. $=0.003593$. 
shrinkage after 56 days drying following 14 days moist curing of concretes having a nominal of $5 \pm 1$ in., lo various independent variables

\begin{tabular}{|c|c|c|c|c|c|c|c|c|c|c|c|}
\hline $\mathrm{Fe}_{2} \mathrm{O}_{3}$ & $\mathrm{Na}_{2} \mathrm{O}$ & $\mathrm{SO}_{3}$ & Loss & $\mathrm{APF}$ & $\mathrm{Zr}_{\mathrm{r}}$ & $\mathrm{SrO}$ & $\mathrm{Zn}$ & $\mathrm{Co}$ & $\mathrm{W} / \mathrm{C}$ & $\begin{array}{l}\text { Percent } \\
\text { wt loss }\end{array}$ & S.D. \\
\hline 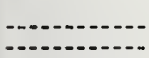 & & & & & & & & & $\begin{array}{c}+0.0489 \\
(0.0232)\end{array}$ & - & 0.00 \\
\hline & & & & & & & & & 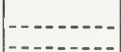 & +0 & 0.005355 \\
\hline - - - & $\begin{array}{r}-0.00588 \\
(0.00194)\end{array}$ & $\begin{array}{r}-0.00776 \\
(0.00117)\end{array}$ & $\begin{array}{r}-0.00403 \\
(0.00067)\end{array}$ & $\begin{array}{c}+0.00000594 \\
(0.00000081)\end{array}$ & & & & & & & 0.004024 \\
\hline & $\begin{array}{r}-0.00687 \\
(0.00198)\end{array}$ & $\begin{array}{r}-0.00822 \\
(0.00117)\end{array}$ & $\begin{array}{r}-0.00389 \\
(0.00068)\end{array}$ & $\begin{array}{r}+0.00000617 \\
(0.00000080)\end{array}$ & $\begin{array}{r}+0.00866 \\
(0.00811)\end{array}$ & $\begin{array}{r}+0.00681 \\
(0.00432)\end{array}$ & $\begin{array}{r}-0.0237 \\
(0.0100)\end{array}$ & & & & 0.003931 \\
\hline & $\begin{array}{r}-0.00608 \\
(0.00335)\end{array}$ & $\begin{array}{c}-0.00876 \\
(0.00209)\end{array}$ & $\begin{array}{r}-0.00431 \\
(0.00125)\end{array}$ & $\begin{array}{r}+0.00000765 \\
(0.00000150)\end{array}$ & $\begin{array}{r}+0.02849 \\
(0.0-478)\end{array}$ & $\begin{array}{r}+0.00263 \\
(0.00750)\end{array}$ & $\begin{array}{r}-0.0420 \\
(0.0217)\end{array}$ & & & $\ldots$ & 0.004328 \\
\hline & $\begin{array}{c}-0.00639 \\
(0.00251)\end{array}$ & $\begin{array}{c}-0.00812 \\
(0.00152)\end{array}$ & $\begin{array}{r}-0.00381 \\
(0.00081)\end{array}$ & $\begin{array}{r}+0.00000492 \\
(0.00000095)\end{array}$ & $\begin{array}{r}*+0.00301 \\
(0.00822)\end{array}$ & $\begin{array}{c}+0.01160 \\
(0.00570)\end{array}$ & $\begin{array}{r}-0.0180 \\
(0.0110)\end{array}$ & & & & $\begin{array}{r}0.003603 \\
-\end{array}$ \\
\hline $\begin{array}{r}+0.000710 \\
(0.000436)\end{array}$ & $\begin{array}{r}-0.00543 \\
(0.00192)\end{array}$ & $\begin{array}{r}-0.00755 \\
(0.00117)\end{array}$ & $\begin{array}{c}-0.00406 \\
(0.00067)\end{array}$ & $\begin{array}{r}+0.00000550 \\
(0.00000077)\end{array}$ & & & & & & & 0.004040 \\
\hline $\begin{array}{c}+0.000926 \\
(0.000430)\end{array}$ & $\begin{array}{r}-0.00601 \\
(0.00195)\end{array}$ & $\begin{array}{r}-0.00799 \\
(0.00116)\end{array}$ & $\begin{array}{r}-0.00388 \\
(0.00066)\end{array}$ & $\begin{array}{r}+0.00000550 \\
(0.00000075)\end{array}$ & $\begin{array}{r}+0.00697 \\
(0.00424)\end{array}$ & & $\begin{array}{r}-0.0164 \\
(0.0100)\end{array}$ & $\begin{array}{r}-0.3628 \\
(0.2426)\end{array}$ & & & 0.003938 \\
\hline $\begin{array}{r}+0.001129 \\
(0.000709)\end{array}$ & $\begin{array}{r}-0.00483 \\
(0.00345)\end{array}$ & $\begin{array}{r}-0.00775 \\
(0.00208)\end{array}$ & $\begin{array}{c}-0.00427 \\
(0.00127)\end{array}$ & $\begin{array}{r}+0.00000610 \\
(0.00000149)\end{array}$ & $\begin{array}{r}*+0.00243 \\
(0.00727)\end{array}$ & & $\begin{array}{r}-0.0232 \\
(0.0217)\end{array}$ & $\begin{array}{r}-0.4419 \\
(0.3592)\end{array}$ & & & 0.004459 \\
\hline $\begin{array}{c}+0.000590 \\
(0.000559)\end{array}$ & $\begin{array}{c}-0.00641 \\
(0.00238)\end{array}$ & $\begin{array}{r}-0.00819 \\
(0.00150)\end{array}$ & $\begin{array}{r}-0.00376 \\
(0.00078)\end{array}$ & $\begin{array}{c}+0.00000506 \\
(0.00000085)\end{array}$ & $\begin{array}{r}+0.01130 \\
(0.00547)\end{array}$ & & $\begin{array}{r}-0.0141 \\
(0.0114)\end{array}$ & $\begin{array}{r}*-0.2183 \\
(0.3624)\end{array}$ & & & 0.003573 \\
\hline
\end{tabular}

pansion after 28 days moist curing following 56 days drying of concretes having a nominal ment ratio of 0.635 , to various independent variables

\begin{tabular}{|c|c|c|c|c|c|c|c|c|c|c|}
\hline $\mathrm{SO}_{3}$ & Loss & APF & $\underset{\text { conteni }}{\text { Air }}$ & $\mathrm{Zn}$ & $\mathrm{Rb}$ & $\mathbf{P}$ & $\mathrm{SrO}$ & $\mathrm{Pb}$ & $\begin{array}{l}\text { Percent } \\
\text { wt gain }\end{array}$ & S.D. \\
\hline & & & & & & & & & $\begin{array}{r}+0.00163 \\
(0.00070)\end{array}$ & 0.003549 \\
\hline $\begin{array}{c}-0.00394 \\
(0.00078)\end{array}$ & $\begin{array}{c}-0.00233 \\
(0.00045)\end{array}$ & $\begin{array}{r}+0.00000294 \\
(0.00000051)\end{array}$ & $\begin{array}{r}+0.000608 \\
(0.000122)\end{array}$ & - & & & & & 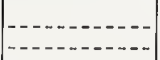 & 0.002802 \\
\hline $\begin{array}{c}-0.00411 \\
(0.00076)\end{array}$ & $\begin{array}{r}-0.00220 \\
(0.00044)\end{array}$ & $\begin{array}{r}+0.00000300 \\
(0.00000050)\end{array}$ & $\begin{array}{r}+0.000646 \\
(0.000118)\end{array}$ & $\begin{array}{r}-0.0102 \\
(0.0065)\end{array}$ & $\begin{array}{r}+0.3234 \\
(0.1150)\end{array}$ & $\begin{array}{r}+0.00369 \\
(0.00198)\end{array}$ & $\begin{array}{r}-0.00378 \\
(0.00268)\end{array}$ & $\begin{array}{r}-0.0518 \\
(0.0345)\end{array}$ & & 0.002711 \\
\hline $\begin{array}{c}-0.00380 \\
(0.00103)\end{array}$ & $\begin{array}{c}-0.00178 \\
(0.00054)\end{array}$ & $\begin{array}{r}+0.00000290 \\
(0.00000061)\end{array}$ & $\begin{array}{r}+0.000784 \\
(0.000170)\end{array}$ & $\begin{array}{r}*-0.0074 \\
(0.0076)\end{array}$ & $\begin{array}{r}+0.2485 \\
(0.1807)\end{array}$ & $\begin{array}{c}+0.00587 \\
(0.00290)\end{array}$ & $\begin{array}{c}-0.00621 \\
(0.00395)\end{array}$ & $\begin{array}{r}-0.0730 \\
(0.0470)\end{array}$ & & 0.002607 \\
\hline $\begin{array}{c}-0.00415 \\
(0.00131)\end{array}$ & $\begin{array}{r}-0.00271 \\
(0.00080)\end{array}$ & $\begin{array}{r}+0.00000315 \\
(0.00000091)\end{array}$ & $\begin{array}{r}+0.000540 \\
(0.000174)\end{array}$ & $\begin{array}{c}-0.0151 \\
(0.0143)\end{array}$ & $\begin{array}{r}+0.3601 \\
(0.1707)\end{array}$ & $\begin{array}{r}*+0.00244 \\
(0.00305)\end{array}$ & $\begin{array}{r}*-0.00314 \\
(0.00397)\end{array}$ & $\begin{array}{r}*-0.0248 \\
(0.0537)\end{array}$ & & 0.002920 \\
\hline $\begin{array}{c}-0.00435 \\
(0.00079)\end{array}$ & $\begin{array}{c}-0.00256 \\
(0.00045)\end{array}$ & $\begin{array}{c}+0.00000326 \\
(0.00000052)\end{array}$ & $\begin{array}{c}+0.000571 \\
(0.000118)\end{array}$ & & & & & & & 0.002779 \\
\hline $\begin{array}{c}-0.00444 \\
(0.00077)\end{array}$ & $\begin{array}{c}-0.00243 \\
(0.00044)\end{array}$ & $\begin{array}{r}+0.00000327 \\
(0.00000051)\end{array}$ & $\begin{array}{c}+0.000606 \\
(0.000116)\end{array}$ & $\begin{array}{r}-0.0099 \\
(0.0064)\end{array}$ & $\begin{array}{r}+0.2853 \\
(0.1150)\end{array}$ & $\begin{array}{r}+0.00406 \\
(0.00196)\end{array}$ & $\begin{array}{c}-0.00409 \\
(0.00265)\end{array}$ & $\begin{array}{r}-0.0499 \\
(0.0341)\end{array}$ & & 0.002677 \\
\hline $\begin{array}{c}-0.00402 \\
(0.00105)\end{array}$ & $\begin{array}{r}-0.00196 \\
(0.00056)\end{array}$ & $\begin{array}{r}+0.00000310 \\
(0.00000063)\end{array}$ & $\begin{array}{r}+0.000748 \\
(0.000168)\end{array}$ & $\begin{array}{r}*-0.0071 \\
(0.0075)\end{array}$ & $\begin{array}{r}+0.2188 \\
(0.1786)\end{array}$ & $\begin{array}{r}+0.00593 \\
(0.00283)\end{array}$ & $\begin{array}{r}-0.00663 \\
(0.00393)\end{array}$ & $\begin{array}{r}-0.0677 \\
(0.0186)\end{array}$ & & 0.002588 \\
\hline $\begin{array}{r}-0.00473 \\
(0.00133)\end{array}$ & $\begin{array}{c}-0.00298 \\
(0.00078)\end{array}$ & $\begin{array}{r}+0.00000356 \\
(0.00000092)\end{array}$ & $\begin{array}{c}+0.000492 \\
(0.000169)\end{array}$ & $\begin{array}{r}-0.0152 \\
(0.0139)\end{array}$ & $\begin{array}{r}+0.3308 \\
(0.1673)\end{array}$ & $\begin{array}{c}+0.00326 \\
(0.00303)\end{array}$ & $\begin{array}{r}*-0.00329 \\
(0.00389)\end{array}$ & $\begin{array}{r}* 0.0307 \\
(0.0528)\end{array}$ & & 0.002868 \\
\hline
\end{tabular}


$\mathrm{T}_{\mathrm{ABLE}}$ 10-13. Coefficients for equations for NAE cements relating $O E X P$, the percentage ex $51 / 2$ bags of cement per cubic yard and a water-ce

\begin{tabular}{|c|c|c|c|c|c|c|c|}
\hline Equation & Note & & Const. & $\mathrm{C}_{3} \mathrm{~A}$ & $\mathrm{C}_{4} \mathrm{AF}$ & $\mathrm{CaO}$ & $\mathrm{Al}_{2} \mathrm{O}_{3}$ \\
\hline $1 \ldots$ & (1) & $\begin{array}{l}\text { OEXP } \\
\text { 8.d. }\end{array}$ & $\begin{array}{l}=+0.0176 \\
=\quad(0.0019)\end{array}$ & & & & 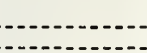 \\
\hline $2 \ldots$ & (1) & $\begin{array}{l}\text { OEXP } \\
\text { s.d. }\end{array}$ & $\begin{array}{l}=+0.0106 \\
=(0.0024)\end{array}$ & $+\underset{(0.000093)}{+0.000688}$ & $\begin{array}{c}+0.000401 \\
(0.000119)\end{array}$ & & \\
\hline $3 \ldots$ & (1) & $\begin{array}{l}\text { OEXP } \\
\text { s.d. }\end{array}$ & $\begin{array}{l}=+0.0117 \\
=(0.0023)\end{array}$ & $\begin{array}{c}+0.000595 \\
(0.000099)\end{array}$ & $\begin{array}{c}+0.000368 \\
(0.000115)\end{array}$ & & \\
\hline $3 \mathrm{~A}$ & ${ }^{(2)}$ & $\begin{array}{l}\text { OEXP (odd) } \\
\text { s.d. }\end{array}$ & $\begin{array}{l}\left.=+{ }_{(0.0127}^{0.0127}\right) \\
=(0.0030)\end{array}$ & $\begin{array}{r}+0.000628 \\
(0.000126)\end{array}$ & $\begin{array}{r}+0.000251 \\
(0.000141)\end{array}$ & & $-\ldots$ \\
\hline $3 \mathrm{~B}_{\ldots}$ & (2) & $\begin{array}{l}\text { OEXP (even) } \\
\text { s.d. }\end{array}$ & $\begin{array}{l}=+0.0108 \\
=(0.0037)\end{array}$ & $\begin{array}{c}+0.000565 \\
(0.000159)\end{array}$ & $\begin{array}{r}+0.000568 \\
(0.000199)\end{array}$ & $--\cdot$ & \\
\hline $4 \ldots .$. & (1) & $\begin{array}{l}\text { OEXP } \\
\text { s.d. }\end{array}$ & $\begin{array}{l}=+0.0412 \\
=(0.0126)\end{array}$ & & 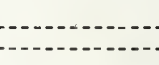 & $\begin{array}{c}-0.000475 \\
(0.000195)\end{array}$ & $+\underset{(0.00024)}{0.00179}$ \\
\hline $5 \ldots$ & (1) & $\begin{array}{l}\text { OEXP } \\
\text { s.d. }\end{array}$ & $\begin{array}{l}=+0.0388 \\
=(0.0122)\end{array}$ & & & $\begin{array}{c}-0.000416 \\
(0.000189)\end{array}$ & $+\underset{(0.00026)}{0.00157}$ \\
\hline $5 \mathrm{~A}$ & ${ }^{(2)}$ & $\begin{array}{l}\text { OEXP (odd) } \\
\text { s.d. }\end{array}$ & $\begin{array}{l}=+0.0101 \\
=(0.0159)\end{array}$ & & & $\begin{array}{r}*+0.000018 \\
(0.000248)\end{array}$ & $\begin{array}{r}+.000169 \\
(0.00033)\end{array}$ \\
\hline 5B... & (2) & $\begin{array}{l}\text { OEXP (even) } \\
\text { s.d. }\end{array}$ & $\begin{array}{l}=+0.0720 \\
=(0.0189)\end{array}$ & & & $\begin{array}{c}-0.000912 \\
(0.000293)\end{array}$ & $\begin{array}{c}+0.00140 \\
(0.00040)\end{array}$ \\
\hline
\end{tabular}

164 cements; $\mathrm{Avg}=0.02031$ percent; S.D. $=0.003520$.

282 cements.

* Coef./s.d. ratio less than 1.

loss on ignition were associated with decreases in the expansion values. Of these variables, differences in fineness, $\mathrm{C}_{3} \mathrm{~A}$, and $\mathrm{SO}_{3}$ had the greatest calculated effect on differences of expansion of the concretes.

TABLE 10-14. Calculated contributions to the percentage expansion after 28 days in water following 56 days air-drying of concretes having a nominal $51 / 2$ bags of cement per cubic yard and a water-cement ratio of 0.635 , and the calculated ranges of such contributions (OEXP)

\begin{tabular}{|c|c|c|c|c|}
\hline $\begin{array}{c}\text { Inde- } \\
\text { pendent } \\
\text { variables }\end{array}$ & $\begin{array}{l}\text { Range of } \\
\text { variables } \\
\text { (percent) }\end{array}$ & $\begin{array}{l}\text { Coefficients } \\
\text { from eq (3) } \\
\text { table 10-13 }\end{array}$ & $\begin{array}{l}\text { Calculated contri- } \\
\text { butions to OEXP }\end{array}$ & $\begin{array}{l}\text { Calculat- } \\
\text { ed ranges } \\
\text { of contri- } \\
\text { butions. } \\
\text { to } \\
\text { OEXP }\end{array}$ \\
\hline 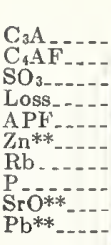 & $\begin{array}{c}0 \text { to } 15 \\
4 \text { to } 17 \\
1.2 \text { to } 3.0 \\
0.3 \text { to } 3.3 \\
* 2500 \text { to } 5500 \\
0 \text { to } 0.2 \\
0 \text { to } 0.01 \\
0 \text { to } 0.5 \\
0 \text { to } 0.4 \\
0 \text { to } 0.05\end{array}$ & $\begin{array}{l}+0.000595 \\
+0.000368 \\
-0.00433 \\
-0.00214 \\
+0.00000315 \\
-0.0110 \\
+0.3894 \\
+0.00438 \\
-0.00394 \\
+0.0450\end{array}$ & $\begin{array}{r}\text { Const. }=+0.0117 \\
0 \text { to }+0.0089 \\
+0.0015 \text { to }+0.0063 \\
-0.0052 \text { to }-0.0130 \\
-0.0006 \text { to }-0.0071 \\
+0.0079 \text { to }+0.0173 \\
0 \text { to }-0.0022 \\
0 \text { to }+0.0039 \\
0 \text { to }+0.0022 \\
0 \text { to }-0.0016 \\
0 \text { to }+0.0022\end{array}$ & $\begin{array}{l}0.0089 \\
0.0048 \\
0.0078 \\
0.0065 \\
0.0094 \\
0.0022 \\
0.0039 \\
0.0022 \\
0.0016 \\
0.0022\end{array}$ \\
\hline
\end{tabular}

$* \mathrm{~cm}^{2} / \mathrm{g}$.

***eofficient of doubtful significance as coef./s.d. ratio was less than 2

b. Expansion of Series A Concretes made with a Slump of $5 \pm 1$-in., Air-dried and then Rewetted (AEXP)

The frequency distributions of the different types of cement with respect to the expansion of Series A concretes (AEXP) are presented in table $10-15$. There was a fairly broad distribution of values and an overlapping of values for cements of the different types.

Equations relating the expansion values of the concrete specimens made of $\mathrm{AE}+\mathrm{NAE}$ cements to various independent variables are presented in table 10-16. Equation 1 indicates
TABLE 10-15. Frequency distribution of cements with respect to expansion after 28 days moist storage following 56 days of drying of concretes having a nominal $5^{1 / 2}$ bags of cement per cubic yard and a $5 \pm 1$ in. slump ( $A E X P)$

\begin{tabular}{|c|c|c|c|c|c|c|c|c|}
\hline \multirow{3}{*}{ Type cement } & \multicolumn{7}{|c|}{ Percentage expansion } & \multirow{3}{*}{ Total } \\
\hline & $\begin{array}{c}0.011 \\
\text { to } \\
0.014\end{array}$ & $\begin{array}{l}0.014 \\
\text { to } \\
0.017\end{array}$ & $\begin{array}{l}0.017 \\
\text { to } \\
0.020\end{array}$ & $\begin{array}{c}0.020 \\
\text { to } \\
0.023\end{array}$ & $\begin{array}{c}0.023 \\
\text { to } \\
0.026\end{array}$ & $\begin{array}{c}0.026 \\
\text { to } \\
0.029\end{array}$ & $\begin{array}{c}0.029 \\
\text { to } \\
0.032\end{array}$ & \\
\hline & \multicolumn{7}{|c|}{ Number of cements } & \\
\hline $\begin{array}{l}\text { I } \\
\text { IA } \\
\text { II } \\
\text { IIA } \\
\text { III } \\
\text { IIIA } \\
\text { IV, V V }\end{array}$ & 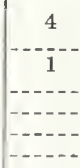 & \begin{tabular}{c|c}
4 \\
-7 \\
-4 \\
-2
\end{tabular} & \begin{tabular}{c}
12 \\
1 \\
26 \\
\hdashline 2 \\
\hdashline 6
\end{tabular} & $\begin{array}{r}25 \\
3 \\
16 \\
1 \\
5 \\
1 \\
4\end{array}$ & \begin{tabular}{c}
24 \\
4 \\
11 \\
-6 \\
\hdashline-
\end{tabular} & \begin{tabular}{c|}
7 \\
$-{ }^{-}$ \\
1 \\
1 \\
1 \\
1
\end{tabular} & \begin{tabular}{c}
3 \\
-1 \\
\hdashline- \\
1 \\
$-\cdots$
\end{tabular} & $\begin{array}{r}79 \\
8 \\
66 \\
2 \\
20 \\
3 \\
15\end{array}$ \\
\hline Total & 5 & 17 & 47 & 55 & 47 & 16 & 6 & 193 \\
\hline
\end{tabular}

that there was no apparent relationship between the water/cement ratio required to obtain concretes of $5 \pm 1$-in slump and the expansion on rewetting the air-dried specimens. There was an indication, significant at the 5percent probability level, of a relationship between the expansion and the percentage weightgain of the specimens made of the different cements as indicated in eq 2 (see also table 10-44). Using only the major potential compounds in eq 3 resulted in a significant reduction in the S.D. value, although the $\mathrm{C}_{3} \mathrm{~S}$ had a coef./s.d. ratio less than 1 and the coefficient for $\mathrm{C}_{4} \mathrm{AF}$ was not highly significant. With the use of additional commonly determined variables in eq 4, a further significant reduction in the S.D. value was obtained, (see table 10-44), and the coefficients for $\mathrm{C}_{3} \mathrm{~S}$ and $\mathrm{C}_{4} \mathrm{AF}$ were more highly significant than in eq 3 . The additional use of the trace elements $\mathrm{Mn}, \mathrm{Ni}, \mathrm{P}$, and 
pansion after 28 days moist curing following 56 days drying of concretes having a nominal ment ratio of 0.635 , to various independent variables

\begin{tabular}{|c|c|c|c|c|c|c|c|c|c|}
\hline $\mathrm{SO}_{3}$ & Loss & APF & $\mathrm{Zn}$ & $\mathrm{Rb}$ & $\mathbf{P}$ & Sro & $\mathrm{Pb}$ & $\begin{array}{l}\text { Percent } \\
\text { wt gain }\end{array}$ & S.D. \\
\hline & & & & & & & & $\begin{array}{r}+0.00105 \\
(0.00074)\end{array}$ & $\begin{array}{c}0.003509 \\
0\end{array}$ \\
\hline $\begin{array}{c}-0.00403 \\
(0.00080)\end{array}$ & $\begin{array}{c}-0.00230 \\
(0.00046)\end{array}$ & $\begin{array}{c}+0.00000301 \\
(0.00000053)\end{array}$ & $\ldots$ & $-2-2$ & $-\ldots$ &..- & $\ldots$ & & 0.002857 \\
\hline $\begin{array}{c}-0.00433 \\
(0.00077)\end{array}$ & $\begin{array}{c}-0.00214 \\
(0.00044)\end{array}$ & $\begin{array}{r}+0.00000315 \\
(0.00000051)\end{array}$ & $\begin{array}{c}-0.0110 \\
(0.0065)\end{array}$ & $\begin{array}{r}+0.3894 \\
(0.1161)\end{array}$ & $\begin{array}{c}+0.00438 \\
(0.00199)\end{array}$ & $\begin{array}{c}-0.00394 \\
(0.00278)\end{array}$ & $\begin{array}{c}-0.0450 \\
(0.0345)\end{array}$ & & 0.002702 \\
\hline $\begin{array}{c}-0.00463 \\
(0.00103)\end{array}$ & $\begin{array}{c}-0.00164 \\
(0.00051)\end{array}$ & $\begin{array}{l}+0.00000310 \\
(0.00000058)\end{array}$ & $\begin{array}{c}-0.0207 \\
(0.0100)\end{array}$ & $\begin{array}{c}+0.2922 \\
(0.1792)\end{array}$ & $\begin{array}{c}+0.00592 \\
(0.00278)\end{array}$ & $\begin{array}{r}*-0.00345 \\
(0.00372)\end{array}$ & $\begin{array}{c}-0.0867 \\
(0.0483)\end{array}$ & & 0.002475 \\
\hline $\begin{array}{c}-0.00325 \\
(0.00128)\end{array}$ & $\begin{array}{c}-0.00323 \\
(0.00088)\end{array}$ & $\begin{array}{c}+0.00000284 \\
(0.00000100)\end{array}$ & $\begin{array}{c}-0.0107 \\
(0.0092)\end{array}$ & $\begin{array}{r}+0.3526 \\
(0.1702)\end{array}$ & $\begin{array}{c}+0.00315 \\
(0.00314)\end{array}$ & $\begin{array}{c}-0.00591 \\
(0.00439)\end{array}$ & $\begin{array}{r}*-0.0234 \\
(0.0513)\end{array}$ & & 0.002912 \\
\hline $\begin{array}{c}-0.00449 \\
(0.00081)\end{array}$ & $\begin{array}{c}-0.00251 \\
(0.00046)\end{array}$ & $\begin{array}{r}+0.00000334 \\
(0.00000054)\end{array}$ &..-- & & 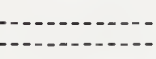 & -- &.-- & & 0.002807 \\
\hline $\begin{array}{c}-0.00468 \\
(0.00078)\end{array}$ & $\begin{array}{c}-0.00235 \\
(0.00045)\end{array}$ & $\begin{array}{r}+0.00000340 \\
(0.00000052)\end{array}$ & $\begin{array}{c}-0.0109 \\
(0.0064)\end{array}$ & $\begin{array}{c}+0.3461 \\
(0.1162)\end{array}$ & $\begin{array}{c}+0.00473 \\
(0.00196)\end{array}$ & $\begin{array}{c}-0.00432 \\
(0.00275)\end{array}$ & -0.0432 & & 0.002664 \\
\hline $\begin{array}{c}-0.00454 \\
(0.00104)\end{array}$ & $\begin{array}{c}-0.00157 \\
(0.00051)\end{array}$ & $\begin{array}{r}+0.00000311 \\
(0.00000060)\end{array}$ & $\begin{array}{c}-0.0213 \\
(0.0101)\end{array}$ & $\begin{array}{c}+0.2940 \\
(0.1819)\end{array}$ & $\begin{array}{c}+0.00629 \\
(0.00276)\end{array}$ & $\begin{array}{c}* 0.00369 \\
(0.00378)\end{array}$ & $\begin{array}{c}-0.0837 \\
(0.0487)\end{array}$ & & 0.002490 \\
\hline $\begin{array}{c}-0.00424 \\
(0.00127)\end{array}$ & $\begin{array}{c}-0.00393 \\
(0.00087)\end{array}$ & $\begin{array}{c}+0.00000362 \\
(0.00000099)\end{array}$ & $\begin{array}{c}-0.0092 \\
(0.0086)\end{array}$ & $\begin{array}{r}+0.3070 \\
(0.1631)\end{array}$ & $\begin{array}{c}+0.00423 \\
(0.00302)\end{array}$ & $\begin{array}{c}-0.00644 \\
(0.00415)\end{array}$ & $\begin{array}{r}*-0.0275 \\
(0.0489)\end{array}$ & & 0.002778 \\
\hline
\end{tabular}

$\mathrm{V}$ in eq 5 resulted in a further significant reduction in the S.D. value.

The use of major oxides with other commonly determined variables in eq 6 resulted in a highly significant reduction in the S.D. value. It may be noted, however, that the coefficient for $\mathrm{Fe}_{2} \mathrm{O}_{3}$ was negative whereas that for $\mathrm{C}_{4} \mathrm{AF}$ in eqs 4 and 5 were positive. Neither was highly significant ${ }^{9}$. The additional use of the trace elements in eq 7 resulted in a further significant reduction in the S.D. value (see table $10-44)$.

In equations for the "odds" and "evens" (eqs $5 \mathrm{~A}, 5 \mathrm{~B}, 7 \mathrm{~A}$ and $7 \mathrm{~B}$ ) there were instances where the coef./s.d. ratios for $\mathrm{C}_{3} \mathrm{~S}, \mathrm{Fe}_{2} \mathrm{O}_{3}, \mathrm{~K}_{2} \mathrm{O}, \mathrm{MgO}$, air content, $\mathrm{Mn}, \mathrm{P}, \mathrm{V}$, and $\mathrm{Ni}$ were less than 1 in one or both, of the pairs of equations for the smaller groups of cements.

A corresponding series of equations for NAE cements is presented in table 10-17. The coefficients of the various independent variables and the reduction in variance resulting from the use of additional independent variables were in reasonable agreement with those presented in the previous table 10-16 where the $\mathrm{AE}$ cements were included.

Using the coefficients of the independent variables from eq 5 of table 10-17 and the approximate ranges of these variables, calculated contributions to the expansion, and the ranges of such contributions were determined. As indicated in table 10-18, increases in $\mathrm{C}_{3} \mathrm{~A}$, $\mathrm{C}_{4} \mathrm{AF}, \mathrm{MgO}, \mathrm{K}_{2} \mathrm{O}$, fineness, and $\mathrm{Mn}$ were associated with increases in the expansion values. Increases in $\mathrm{SO}_{3}$ and Loss were associated with decreases in the expansion values. Differences in $\mathrm{C}_{3} \mathrm{~A}$, fineness, and $\mathrm{SO}_{3}$ had the largest cal-

\footnotetext{
- The $\mathrm{C}_{4} \mathrm{AF}$ value was computed as a constant times the $\mathrm{Fe}_{2} \mathrm{O}_{3}$ in accordance with specification requirements.
}

culated effect on differences of expansion values obtained.

\subsection{Residual Shrinkage or Difference between the Percentage Shrinkage During Drying and the Percentage Expansion with Sub- sequent Rewetting}

a. Residual Shrinkage of Series $O$ Concretes made with a water/cement Ratio of $\mathbf{0 . 6 3 5}$ (ODSX)

The frequency distributions of the residual shrinkage, defined as the difference between the shrinkage during air drying for 56 days and the expansion during the subsequent water storage for 28 days, of the Series $\mathrm{O}$ concretes are presented in table 10-19. There was a fairly broad range of values and an overlapping of the values obtained with the different types of cement.

Equations presenting the variables associated with the residual-shrinkage values for $\mathrm{AE}+\mathrm{NAE}$ cements are presented in table 10-20. The use of commonly determined variables in eq 1 resulted in a highly significant reduction in the S.D. value, and the additional use of the trace elements $\mathrm{SrO}, \mathrm{Li}$, and $\mathrm{Rb}$ in eq 2 resulted in a further highly significant reduction in the S.D. value. The S.D. value of eq 2 was higher than that obtained when the shrinkage values were used as independent variables as in eq 3 . The use of additional independent variables having coef./s.d. ratios greater than 1 in eq 4 caused a significant reduction in the S.D. value (see table 10-44). The coef./s.d. ratios of $\mathrm{C}_{4} \mathrm{AF}, \mathrm{APF}$, and Loss were less than 1 when included with the other variables in eq 4, but the coef./s.d. ratio for $\mathrm{MgO}$ was greater than 1. Except for $\mathrm{SrO}$ and 
TABLE 10-16. Coefficients for equations for $A E+N A E$ cements relating $A E X P$, the percent a nominal $51 / 2$ bags of cement per cubic yard with

\begin{tabular}{|c|c|c|c|c|c|c|c|}
\hline Fquation & Note & & Const. & $\mathrm{C}_{3} \mathrm{~A}$ & $\mathrm{C}_{3} \mathrm{~S}$ & $\mathrm{C}_{4} \mathrm{AF}$ & $\mathrm{K}_{2} \mathrm{O}$ \\
\hline $1 \ldots \ldots \ldots$ & (1) & $\begin{array}{l}\text { AEXP } \\
\text { s.d. }\end{array}$ & $\begin{array}{l}=+0.0237 \\
=(0.0076)\end{array}$ & 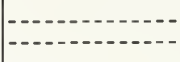 & 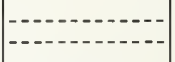 & 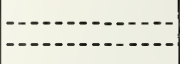 & -- \\
\hline $2+\ldots+\ldots-n$ & (1) & $\begin{array}{l}\text { AEXP } \\
\text { s.d. }\end{array}$ & $\begin{array}{l}=+0.0163 \\
=(0.0020)\end{array}$ & 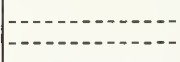 & 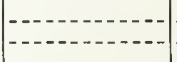 & 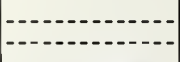 & \\
\hline 3.-1-10-1 & (1) & $\begin{array}{l}\text { A EXP } \\
\text { s.d. }\end{array}$ & $\begin{array}{l}=+0.0166 \\
=(0.0032)\end{array}$ & $\begin{array}{r}+0.000485 \\
(0.000105)\end{array}$ & $\mid \begin{array}{r}* 0.0000389 \\
(0.0000420)\end{array}$ & $\begin{array}{c}+0.000236 \\
(0.000150)\end{array}$ & --- \\
\hline 4 & (1) & $\begin{array}{l}\text { AEXP } \\
\text { s.d. }\end{array}$ & $\begin{array}{l}=+0.0107 \\
=(0.0030)\end{array}$ & $\begin{array}{c}+0.000710 \\
(0.000101)\end{array}$ & $\begin{array}{r}-0.0000542 \\
(0.0000395)\end{array}$ & $\begin{array}{c}+0.000366 \\
(0.000130)\end{array}$ & $\begin{array}{c}+0.00174 \\
(0.00130)\end{array}$ \\
\hline 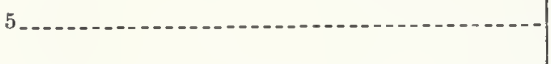 & (1) & $\begin{array}{l}\text { AEXP } \\
\text { s.d. }\end{array}$ & $\begin{array}{l}=+0.0085 \\
=(0.0032)\end{array}$ & $\begin{array}{c}+0.000725 \\
(0.000110)\end{array}$ & $\begin{array}{r}-0.0000440 \\
(0.0000387)\end{array}$ & $\begin{array}{r}+0.000344 \\
(0.000131)\end{array}$ & $\begin{array}{c}+0.00260 \\
(0.00130)\end{array}$ \\
\hline 5A & $\left({ }^{2}\right)$ & $\begin{array}{l}\operatorname{AEXP}(\text { odd })= \\
\text { s.d. }\end{array}$ & $\begin{array}{l}=+0.0107 \\
=(0.0042)\end{array}$ & $\begin{array}{c}+0.000658 \\
(0.000142)\end{array}$ & $\begin{array}{r}*-0.0000482 \\
(0.0000489)\end{array}$ & $\begin{array}{c}+0.000366 \\
(0.000170)\end{array}$ & $\begin{array}{c}+0.00479 \\
(0.00167)\end{array}$ \\
\hline \multirow[t]{2}{*}{ 5B...n } & \multirow[t]{2}{*}{$\left({ }^{3}\right)$} & \multirow{2}{*}{\multicolumn{2}{|c|}{$\begin{array}{l}\operatorname{AEXP}(\text { even })=+0.0069 \\
\text { s.d. }\end{array}$}} & $\begin{array}{r}+0.000714 \\
-(0.000172) \\
\end{array}$ & $\begin{array}{r}* 0.0000183 \\
(0.0000662) \\
\end{array}$ & $\begin{array}{r}+0.000237 \\
(0.000208) \\
\end{array}$ & \multirow[t]{2}{*}{$\begin{array}{r}*+0.00055 \\
(0.00217)\end{array}$} \\
\hline & & & & $\mathrm{CaO}$ & $\mathrm{Ai}_{2} \mathrm{O}_{3}$ & $\mathrm{Fe}_{2} \mathrm{O}_{3}$ & \\
\hline $6 \ldots$ & (1) & $\begin{array}{l}\text { AEXP } \\
\text { s.d. }\end{array}$ & $\begin{array}{l}=+0.0551 \\
=(0.0167)\end{array}$ & $\begin{array}{r}-0.000682 \\
(0.000246)\end{array}$ & $\begin{array}{r}+0.00182 \\
(0.00027)\end{array}$ & $\begin{array}{r}-0.000451 \\
(0.000258\end{array}$ & $\begin{array}{r}+0.00141 \\
(0.00131)\end{array}$ \\
\hline 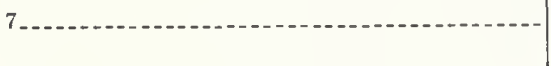 & (1) & $\begin{array}{l}\text { AEXP } \\
\text { s.d. }\end{array}$ & $\begin{array}{l}=+0.0483 \\
=(0.0167)\end{array}$ & $\begin{array}{c}-0.000606 \\
(0.000248)\end{array}$ & $\begin{array}{c}+0.00186 \\
(0.00029)\end{array}$ & $\begin{array}{r}-0.000521 \\
(0.000351)\end{array}$ & $\begin{array}{c}+0.00237 \\
(0.00132)\end{array}$ \\
\hline $7 A_{-1}$ & $\left({ }^{2}\right)$ & $\begin{array}{l}\operatorname{AEXP} \text { (odd) } \\
\text { s.d. }\end{array}$ & $\begin{array}{l}=+0.0412 \\
=(0.0226)\end{array}$ & $\begin{array}{r}-0.000475 \\
(0.000335)\end{array}$ & $\begin{array}{c}+0.00169 \\
(0.00037)\end{array}$ & $\begin{array}{r}* 0.000213 \\
(0.000457)\end{array}$ & $\begin{array}{r}+0.00451 \\
(0.00172)\end{array}$ \\
\hline $7 \mathrm{~B}$ & (a) & $\begin{array}{l}\text { AEXP (even) } \\
\text { s.d. }\end{array}$ & $\begin{array}{l}=+0.0493 \\
=(0.0257)\end{array}$ & $\begin{array}{c}-0.000629 \\
(0.000382)\end{array}$ & $\begin{array}{r}+0.00185 \\
(0.00045)\end{array}$ & $\begin{array}{r}-0.000932 \\
(0.000552)\end{array}$ & $\begin{array}{r}*+0.00077 \\
(0.00209)\end{array}$ \\
\hline
\end{tabular}

1171 cements; Avg $=0.02100$ percent; S.D. $=0.003823$.

286 cements. $\quad 385$ cements.

* Coef./s.d. ratio less than 1.

$\mathrm{T}_{\mathrm{ABLE}}$ 10-17. Coefficients for equations for $N A E$ cements relating $A E X P$, the percentage nominal $51 / 2$ bags of cement per cubic yard with a

\begin{tabular}{|c|c|c|c|c|c|c|c|}
\hline Equation & Note & & Const. & $\mathrm{C}_{3} \mathrm{~A}$ & $\mathrm{C}: \mathrm{S}$ & $\mathrm{C} \triangleleft \mathrm{AF}$ & $\mathrm{K}_{2} \mathrm{O}$ \\
\hline 1 & (1) & $\begin{array}{l}\text { AEXP } \\
\text { s.d. }\end{array}$ & $\begin{array}{l}=+0.0073 \\
=(0.0101)\end{array}$ & $\mid-1-1-1-2-1$ & 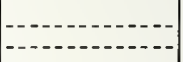 & 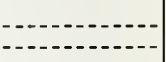 & - \\
\hline 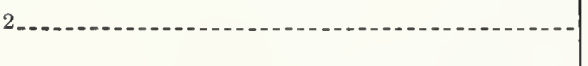 & $(1)$ & $\begin{array}{l}\text { A EXP } \\
\text { s.d. }\end{array}$ & $\begin{array}{l}=+0.0159 \\
=(0.0020)\end{array}$ & 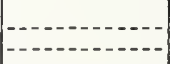 & 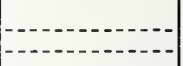 & 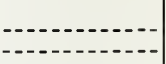 & --- \\
\hline 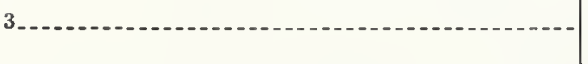 & $(1)$ & $\begin{array}{l}\text { AEXP } \\
\text { s.d. }\end{array}$ & $\begin{array}{l}=+0.0165 \\
=(0.0033)\end{array}$ & $\begin{array}{r}+0.000498 \\
(0.000107)\end{array}$ & $\begin{array}{c}-0.0000443 \\
(0.0000435)\end{array}$ & $\begin{array}{c}+0.000254 \\
(0.000154)\end{array}$ & - \\
\hline 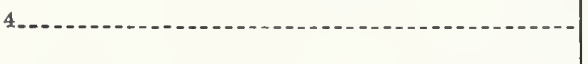 & (1) & $\begin{array}{l}\text { AEXP } \\
\text { s.d. }\end{array}$ & $\begin{array}{l}=+0.0122 \\
=(0.0031)\end{array}$ & $\begin{array}{c}+0.000722 \\
(0.000102)\end{array}$ & $\begin{array}{r}-0.0000645 \\
(0.0000401)\end{array}$ & $\begin{array}{c}+0.000335 \\
(0.000130)\end{array}$ & $\begin{array}{r}+0.00175 \\
(0.00131)\end{array}$ \\
\hline 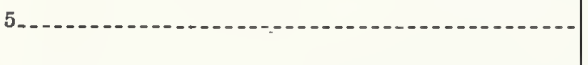 & (1) & $\begin{array}{l}\text { AEXP } \\
\text { s.d. }\end{array}$ & $\begin{array}{l}=+0.0094 \\
=(0.0032)\end{array}$ & $\begin{array}{c}+0.000748 \\
(0.000111)\end{array}$ & $\begin{array}{r}-0.0000504 \\
(0.0000390)\end{array}$ & $\begin{array}{c}+0.000329 \\
(0.000130)\end{array}$ & $\begin{array}{r}+0.00270 \\
(0.00130)\end{array}$ \\
\hline - & $\left({ }^{2}\right)$ & $\begin{array}{l}\text { AEXP (odd) } \\
\text { s.d. }\end{array}$ & $\begin{array}{l}=+0.0152 \\
=(0.0040)\end{array}$ & $\begin{array}{c}+0.000797 \\
(0.000152)\end{array}$ & $\begin{array}{r}-0.0001181 \\
(0.0000452)\end{array}$ & $\begin{array}{c}+0.000303 \\
(0.000169)\end{array}$ & $\begin{array}{r}+0.00363 \\
(0.00186)\end{array}$ \\
\hline \multirow[t]{2}{*}{ 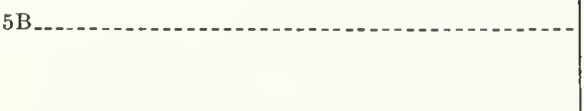 } & \multirow[t]{2}{*}{$(3)$} & \multirow[t]{2}{*}{$\begin{array}{l}\text { AEXP (even) } \\
\text { s.d. }\end{array}$} & \multirow[t]{2}{*}{$\begin{array}{l}=+0.0024 \\
=(0.0052)\end{array}$} & $\begin{array}{r}+0.000738 \\
(0.000705) \\
\end{array}$ & $\begin{array}{r}*+0.0000484 \\
(0.0000706) \\
\end{array}$ & $\begin{array}{r}+0.000365 \\
(0.000184) \\
\end{array}$ & \multirow[t]{2}{*}{$\begin{array}{r}+0.00254 \\
(0.00197)\end{array}$} \\
\hline & & & & $\mathrm{CaO}$ & $\mathrm{Al}_{2} \mathrm{O}_{3}$ & $\mathrm{Fe}_{2} \mathrm{O}_{3}$ & \\
\hline 6 & (1) & $\begin{array}{l}\text { AEXP } \\
\text { s.d. }\end{array}$ & $\begin{array}{l}=+0.0606 \\
=(0.0168)\end{array}$ & $\begin{array}{c}-0.000749 \\
(0.000247)\end{array}$ & $\begin{array}{c}+0.00186 \\
(0.00027)\end{array}$ & $\begin{array}{c}-0.000578 \\
(0.000358)\end{array}$ & $\begin{array}{r}*+0.00132 \\
(0.00132)\end{array}$ \\
\hline $7 .-$. & (1) & $\begin{array}{l}\text { AEXP } \\
\text { s.d. }\end{array}$ & $\begin{array}{l}=+0.0533 \\
=(0.0168)\end{array}$ & $\begin{array}{r}-0.000672 \\
(0.000248)\end{array}$ & $\begin{array}{r}+0.00193 \\
(0.00029)\end{array}$ & $\begin{array}{c}-0.000626 \\
(0.000348)\end{array}$ & $\begin{array}{r}+0.00238 \\
(0.00133)\end{array}$ \\
\hline $7 A_{-}$ & $(2)$ & $\begin{array}{l}\text { AEXP (odd) } \\
\text { s.d. }\end{array}$ & $\begin{array}{l}=+0.0582 \\
=(0.0206)\end{array}$ & $\begin{array}{r}-0.000717 \\
(0.000303)\end{array}$ & $\begin{array}{r}+0.00209 \\
(0.00040)\end{array}$ & $\begin{array}{c}-0.000595 \\
(0.000464)\end{array}$ & $\begin{array}{r}+0.00274 \\
(0.00192)\end{array}$ \\
\hline $7 \mathrm{~B}_{--}$ & $\left({ }^{3}\right)$ & $\begin{array}{l}\text { AEXP (even) } \\
\text { s.d. }\end{array}$ & $\begin{array}{l}=+0.0357 \\
=(0.0290)\end{array}$ & $\begin{array}{r}-0.000447 \\
(0.000434)\end{array}$ & $\begin{array}{r}+0.00195 \\
(0.00045)\end{array}$ & $\begin{array}{c}-0.000604 \\
(0.000524)\end{array}$ & $\begin{array}{r}+0.00265 \\
(0.00204)\end{array}$ \\
\hline
\end{tabular}

1159 cements; Avg $=0.02085$ percent; S.D. $=0.003821 . \quad 280$ cements. $\quad 379$ cements. $\quad *$ Coef./s,d, ratio less than 1. 
age expansion after 28 days moist storage following 56 days of drying of concretes having a $5 \pm 1$ in. slump, to various independent variables

\begin{tabular}{|c|c|c|c|c|c|c|c|c|c|c|c|}
\hline $\mathrm{SO}_{3}$ & $\mathrm{MgO}$ & Loss & $\mathrm{APF}$ & $\underset{\text { content }}{\text { Air }}$ & $\mathrm{Mn}$ & $\mathbf{P}$ & $\mathrm{V}$ & $\mathrm{Ni}$ & $\mathrm{W} / \mathrm{C}$ & $\begin{array}{l}\text { Percent } \\
\text { wt gain }\end{array}$ & S.D. \\
\hline & & & & & & & & & $\begin{array}{r}*-0.00428 \\
(0.01188)\end{array}$ & & $\begin{array}{r}0.003832 \\
-\end{array}$ \\
\hline & & & & & & & & & & $\begin{array}{c}+0.00184 \\
(0.00075)\end{array}$ & $\begin{array}{r}0.003767 \\
-\end{array}$ \\
\hline - & & |-- & & & & & & & & & 0.003611 \\
\hline $\begin{array}{r}-0.00494 \\
(0.00091)\end{array}$ & $+\begin{array}{c}0.000436 \\
(0.000217)\end{array}$ & $\begin{array}{c}-0.00252 \\
(0.00050)\end{array}$ & $\begin{array}{c}+0.00000393 \\
(0.00000062)\end{array}$ & $+\begin{array}{c}0.000214 \\
(0.000117)\end{array}$ & & & & & & & 0.003011 \\
\hline $\begin{array}{c}-0.00548 \\
(0.00090)\end{array}$ & $+\begin{array}{c}0.000428 \\
(0.00022)\end{array}$ & $\begin{array}{c}-0.00250 \\
(0.00049)\end{array}$ & $+\begin{array}{c}+0.00000431 \\
(0.00000062)\end{array}$ & $+\begin{array}{c}0.000208 \\
(0.000114)\end{array}$ & $\begin{array}{r}+0.00418 \\
(0.00195)\end{array}$ & $\begin{array}{c}+0.00284 \\
(0.00215)\end{array}$ & $\begin{array}{c}+0.0237 \\
(0.0154)\end{array}$ & $\begin{array}{r}+0.1149 \\
(0.0830\end{array}$ & & & 0.002916 \\
\hline $\begin{array}{c}-0.00582 \\
(0.00128)\end{array}$ & $\begin{array}{r}*+0.000257 \\
(0.000304)\end{array}$ & $\begin{array}{c}-0.00285 \\
(0.00070)\end{array}$ & $+\begin{array}{c}+0.00000386 \\
(0.00000086)\end{array}$ & $+\underset{(0.000163)}{0.000316}$ & $\begin{array}{r}*+0.00043 \\
(0.00310)\end{array}$ & $\begin{array}{r}+0.00510 \\
(0.00331)\end{array}$ & $*+\underset{(0.0196)}{0.0065}$ & $\begin{array}{c}+0.2155 \\
(0.1172)\end{array}$ & & & 0.002668 \\
\hline $\begin{array}{c}-0.00453 \\
(0.00132)\end{array}$ & $\begin{array}{r}+0.000555 \\
(0.000342)\end{array}$ & $\begin{array}{r}-0.00204 \\
(0.00071)\end{array}$ & $\begin{array}{c}+0.00000429 \\
(0.00000095)\end{array}$ & $\begin{array}{r}*+0.000114 \\
\quad(0.000170)\end{array}$ & $\begin{array}{r}+0.00615 \\
(0.00278)\end{array}$ & $*+\begin{array}{c}0.00051 \\
(0.00303)\end{array}$ & $+\underset{(0.0260)}{0.0533}$ & $\begin{array}{r}*+0.0043 \\
\quad(0.1353)\end{array}$ & & & 0.003125 \\
\hline $\begin{array}{c}-0.00522 \\
(0.00091)\end{array}$ & - & $\begin{array}{c}-0.00296 \\
(0.00051)\end{array}$ & $+\begin{array}{r}+0.00000398 \\
(0.00000059)\end{array}$ & $\begin{array}{r}+0.000206 \\
(0.000117)\end{array}$ & & & & & & & $\begin{array}{r}0.002998 \\
-\end{array}$ \\
\hline $\begin{array}{c}-0.00572 \\
(0.00091)\end{array}$ & & $\begin{array}{c}-0.00290 \\
(0.00050)\end{array}$ & $+\begin{array}{c}+0.00000435 \\
(0.00000060)\end{array}$ & $\begin{array}{r}+0.000202 \\
(0.000114)\end{array}$ & $\begin{array}{r}+0.00425 \\
(0.00194)\end{array}$ & $\begin{array}{r}+0.00278 \\
(0.00213)\end{array}$ & $\begin{array}{c}+0.0229 \\
(0.0151)\end{array}$ & $\begin{array}{r}+0.1098 \\
(0.0828)\end{array}$ & & & 0.002909 \\
\hline $\begin{array}{c}-0.00596 \\
(0.00129)\end{array}$ & ..... & $\begin{array}{r}-0.00316 \\
(0.00074)\end{array}$ & $\begin{array}{c}+0.00000381 \\
(0.00000083)\end{array}$ & $+\underset{(0.000162)}{0.00031 .1}$ & $\begin{array}{r}*+0.00031 \\
(0.00307)\end{array}$ & $\begin{array}{r}+0.00505 \\
(0.00328)\end{array}$ & $\begin{array}{r}*+0.0071 \\
(0.0185)\end{array}$ & $\begin{array}{r}+0.2149 \\
(0.1164)\end{array}$ & & & 0.002650 \\
\hline $\begin{array}{c}-0.00479 \\
(0.00132)\end{array}$ & & $\begin{array}{c}-0.00246 \\
(0.00071)\end{array}$ & $\begin{array}{r}+0.00000450 \\
(0.00000091)\end{array}$ & $\begin{array}{r}*+0.000097 \\
\quad(0.000168)\end{array}$ & $\begin{array}{r}+0.00635 \\
(0.00274)\end{array}$ & $\begin{array}{r}*+0.00043 \\
(0.00302)\end{array}$ & $+\begin{array}{c}0.0531 \\
(0.0258)\end{array}$ & $\begin{array}{r}*-0.0073 \\
(0.1346)\end{array}$ & & & 0.003110 \\
\hline
\end{tabular}

xpansion after 28 days moist storage following 56 days of drying of concretes having a $5 \pm 1$ in. slump, to various independent variables

\begin{tabular}{|c|c|c|c|c|c|c|c|c|c|c|}
\hline $\mathrm{SO}_{3}$ & $\mathrm{MgO}$ & Loss & $A P F$ & $\mathrm{Mn}$ & P & V & $\mathrm{Ni}$ & $\mathrm{W} / \mathrm{C}$ & $\begin{array}{l}\text { Percent } \\
\text { wt gain }\end{array}$ & S.D. \\
\hline & & & & & & & & $\begin{array}{l}2111 \\
1583)\end{array}$ & & 0.003811 \\
\hline & & & & & & & & & $+\begin{array}{l}+0.00190 \\
(0.00077)\end{array}$ & $\begin{array}{r}0.003760 \\
-\end{array}$ \\
\hline & & & & & & & & & & 0.003597 \\
\hline $\begin{array}{c}-0.00523 \\
(0.00091)\end{array}$ & $\begin{array}{r}+0.000438 \\
(0.000220)\end{array}$ & $\begin{array}{c}-0.00243 \\
(0.00050)\end{array}$ & $\begin{array}{r}+0.00000393 \\
(0.00000063)\end{array}$ & & & & & & & $\begin{array}{r}0.002978 \\
-\end{array}$ \\
\hline $\begin{array}{c}-0.00588 \\
(0.00090)\end{array}$ & $\begin{array}{r}+0.000446 \\
(0.000222)\end{array}$ & $\begin{array}{c}-0.00240 \\
(0.00049)\end{array}$ & $\begin{array}{r}+0.00000434 \\
(0.00000062)\end{array}$ & $\begin{array}{r}+0.00413 \\
(0.00201)\end{array}$ & $\begin{array}{c}+0.00272 \\
(0.00212)\end{array}$ & $\begin{array}{c}+0.0297 \\
(0.0152)\end{array}$ & $\begin{array}{c}+0.1096 \\
(0.0828)\end{array}$ & & & $\begin{array}{r}0.002861 \\
-\end{array}$ \\
\hline $\begin{array}{c}-0.00765 \\
(0.00121)\end{array}$ & $\begin{array}{r}*+0.000119 \\
(0.000285)\end{array}$ & $\begin{array}{c}-0.00225 \\
(0.00065)\end{array}$ & $\begin{array}{r}+0.00000467 \\
(0.00000681)\end{array}$ & $\begin{array}{r}*-0.00103 \\
(0.00288)\end{array}$ & $\begin{array}{c}+0.00396 \\
(0.00315)\end{array}$ & $\begin{array}{r}*-0.0007 \\
(0.0180)\end{array}$ & $\begin{array}{r}+0.2475 \\
(0.1142)\end{array}$ & & & 0.002572 \\
\hline $\begin{array}{c}-0.00466 \\
(0.00140)\end{array}$ & $\begin{array}{r}+0.000597 \\
(0.000356)\end{array}$ & $\begin{array}{c}-0.00240 \\
(0.00080)\end{array}$ & $\begin{array}{r}+0.00000407 \\
(0.00000097)\end{array}$ & $\begin{array}{r}+0.00707 \\
(0.00294)\end{array}$ & $\begin{array}{r}*-0.00057 \\
(0.00308)\end{array}$ & $\begin{array}{r}+0.0715 \\
(0.0262)\end{array}$ & $\begin{array}{r}*-0.0023 \\
(0.1301)\end{array}$ & & & 0.003032 \\
\hline $\begin{array}{c}-0.00553 \\
(0.00091)\end{array}$ & & $\begin{array}{r}-0.00290 \\
(0.00051)\end{array}$ & $\begin{array}{r}+0.00000395 \\
(0.00000059)\end{array}$ & & & & & & & 0.002959 \\
\hline $\begin{array}{r}-0.00615 \\
(0.00091)\end{array}$ & & $\begin{array}{c}-0.00282 \\
(0.00050)\end{array}$ & $\begin{array}{r}+0.00000438 \\
(0.00000060)\end{array}$ & $\begin{array}{r}+0.00415 \\
(0.00200)\end{array}$ & $\begin{array}{c}+0.00262 \\
(0.00211)\end{array}$ & $\begin{array}{r}+0.0293 \\
(0.0149)\end{array}$ & $\begin{array}{r}+0.1028 \\
(0.0824)\end{array}$ & & & 0.002848 \\
\hline $\begin{array}{c}-0.00765 \\
(0.00121)\end{array}$ & & $\begin{array}{c}-0.00268 \\
(0.00070)\end{array}$ & $+\underset{(0.00000079)}{0.00000435}$ & $\begin{array}{r}*-0.00131 \\
(0.0029)\end{array}$ & $\begin{array}{r}+0.00388 \\
(0.00318)\end{array}$ & $*+\begin{array}{r}0.0053 \\
(0.0177)\end{array}$ & $\begin{array}{r}+0.2334 \\
(0.1151)\end{array}$ & & & 0.002595 \\
\hline $\begin{array}{c}-0.00471 \\
(0.00144)\end{array}$ & & $\begin{array}{c}-0.00269 \\
(0.00078)\end{array}$ & $\begin{array}{r}+0.00000442 \\
(0.00000095)\end{array}$ & $\begin{array}{r}+0.00703 \\
(0.00296)\end{array}$ & $\begin{array}{r}* 0.00054 \\
(0.00310)\end{array}$ & $\begin{array}{c}+0.0689 \\
(0.0262)\end{array}$ & $\begin{array}{r}*-0.0258 \\
(0.1302)\end{array}$ & & & 0.003050 \\
\hline
\end{tabular}


TABLE 10-18. Calculated contributions to the percentage expansion after 28 days in water following 56 days air-drying of concretes having a nominal $5 \frac{1}{2}$ bags of cement per cubic yard and a slump of $5 \pm 1$-in., and the calculated ranges of such contributions ( $A E \overline{X P}$ )

\begin{tabular}{|c|c|c|c|c|}
\hline $\begin{array}{c}\text { Inde- } \\
\text { pendent } \\
\text { variables }\end{array}$ & $\begin{array}{l}\text { Range of } \\
\text { variables } \\
\text { (percent) }\end{array}$ & $\begin{array}{l}\text { Coefficients } \\
\text { froin eq }(5) \\
\text { table 10-17 }\end{array}$ & $\begin{array}{l}\text { Calculated contri- } \\
\text { butions to } \mathrm{AEXP}\end{array}$ & $\begin{array}{l}\text { Calculat- } \\
\text { ed ranges } \\
\text { of contri- } \\
\text { butions } \\
\text { to } \\
\text { AEXP }\end{array}$ \\
\hline 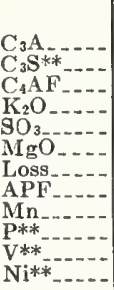 & $\begin{array}{c}0 \text { to } 15 \\
20 \text { to } 65 \\
4 \text { to } 17 \\
0 \text { to } 1.1 \\
1.2 \text { to } 3.0 \\
0 \text { to } 5.0 \\
0.3 \text { to } 3.3 \\
* 2500 \text { to } 5500 \\
0 \text { to } 1.0 \\
0 \text { to } 0.5 \\
0 \text { to } 0.1 \\
0 \text { to } 0.02\end{array}$ & $\begin{array}{l}+0.000748 \\
\pm 0.0000564 \\
+0.000329 \\
+0.00270 \\
-0.00588 \\
+0.000446 \\
-0.00240 \\
+0.00000434 \\
+0.00413 \\
+0.00272 \\
+0.0297 \\
+0.1096\end{array}$ & $\begin{array}{r}\text { Const. }=+0.0094 \\
0 \text { to }+0.0112 \\
-0.0010 \text { to }-0.0033 \\
+0.0013 \text { to }+0.0056 \\
0 \text { to }+0.0030 \\
-0.0071 \text { to }-0.0176 \\
0 \text { to }+0.0022 \\
-0.0007 \text { to }-0.0079 \\
+0.0108 \text { to }+0.0239 \\
0 \text { to }+0.0041 \\
0 \text { to }+0.0014 \\
0 \text { to }+0.0030 \\
0 \text { to }+0.0021\end{array}$ & $\begin{array}{l}0.0112 \\
0.0023 \\
0.0043 \\
0.0030 \\
0.0105 \\
0.0022 \\
0.0072 \\
0.0131 \\
0.0041 \\
0.0014 \\
0.0030 \\
0.0021\end{array}$ \\
\hline
\end{tabular}

$* \mathrm{~cm}^{2} / \mathrm{g}$.

**Coefticient of doubtful significance as coef./s.d. ratio was less than 2 .
$\mathrm{Rb}$, the coefficients of none of the added independent variables were highly significant. In eqs $2 \mathrm{~A}$ and $2 \mathrm{~B}, \mathrm{Na}_{2} \mathrm{O}$, air content, and $\mathrm{Li}$ had coef./s.d. ratios less than 1 in one or the other of the smaller groups of cements. In eqs $4 \mathrm{~A}$ and $4 \mathrm{~B}$, for the "odds" and "evens", $\mathrm{Na}_{2} \mathrm{O}, \mathrm{C}_{3} \mathrm{~A} /$ $\mathrm{SO}_{3}$, air content, $\mathrm{Li}$, and $\mathrm{MgO}$ had coef./s.d. ratios less than 1 .

A corresponding series of equations for the NAE cements is presented in table 10-21. As in the previous table, the residual shrinkage appeared highly related to the initial shrinkage (see eq 3). Other additional independent variables such as $\mathrm{SrO}$ and $\mathrm{Rb}$ appeared to have highly significant effects as indicated in eq 4. If the relationship of the difference between the shrinkage and expansion is computed only with the chemical composition and fineness of the cement and the air content of the concrete as

TABLE 10-19. Frequency distribution of cements with respect to difference between the shrinkage and subsequent expansion of concrete of nominal $51 / 2$ bags of cement per cubic yard made with a water-cement ratio of 0.635 (ODSX)

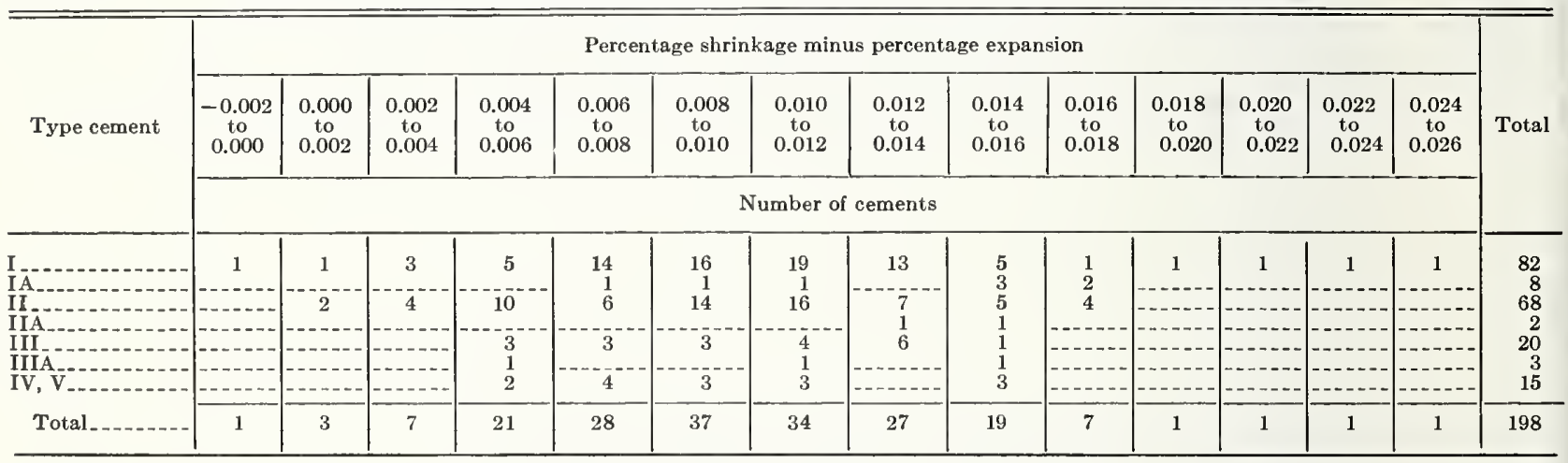

independent variables as in eq 2, a higher S.D. value is obtained.

Calculated contributions and ranges of contributions to the residual shrinkage based on eq 2 , table 10-21, are given in table 10-22. Increases in $\mathrm{C}_{4} \mathrm{AF}, \mathrm{C}_{3} \mathrm{~A} / \mathrm{SO}_{3}$, fineness, and $\mathrm{SrO}$ appear to be associated with increases in the residual-shrinkage values. Increases of $\mathrm{Na}_{2} \mathrm{O}$, loss on ignition, and $\mathrm{Rb}$ were associated with a decrease in the residual-shrinkage values.

\section{b. Residual Shrinkage of Series A Concretes made hav- ing a Slump of $5 \pm 1 \mathrm{in.}$ (ADSX)}

The frequency distribution of the cements with respect to the residual shrinkage of specimens made of Series A concretes is presented in table 10-23. There was a fairly broad distribution of values, and an overlapping of the values for the cements of the different types.

A series of equations is presented in table 10-24 to indicate the variables associated with the values for the residual shrinkage of the Series A concretes made of AE + NAE cements. A corresponding series of equations for the NAE cements is presented in table 10-25. The independent variables associated with the shrinkage-expansion differences for the specimens made of Series A concretes and those previously reported in tables $10-20$ and $10-21$ made of Series $O$ concretes are in reasonable agreement as are the coefficients of these variables. The differences between shrinkage and expansion were significantly associated with the magnitude of the shrinkage as indicated in eq 3 of the two tables (see also table 10-44). The additional use of commonly determined variables in eq 4 , or those with trace elements in eq 5 , resulted in significantly lower S.D. values. The use of commonly determined variables in eq 1 or those with trace elements in eq 2 , but not including the shrinkage as an independent variable, each resulted in significant reductions in the S.D. values, but these values were higher than in eqs 3,4 and 5 where the shrinkage was also included as an independent variable.

Calculated contributions and ranges of contributions of the variables of eq 2 , table 10-25, 





TABLE 10-22. Calculated contributions to the percentage shrinkage after 56 days drying minus the percentage expansion after 28 days in water of concretes having a nominal 5 ! 2 bags of cement per cubic yard and a water-cement ratio of 0.635 , and the calculated ranges of such contributions $(O D S X=O S H R-$ $O E X P)$

\begin{tabular}{|c|c|c|c|c|}
\hline $\begin{array}{l}\text { Inde- } \\
\text { pendent } \\
\text { variables }\end{array}$ & $\begin{array}{l}\text { Range of } \\
\text { variables } \\
\text { (percent) }\end{array}$ & $\begin{array}{l}\text { Coefficients } \\
\text { from eq }(2) \\
\text { table } 10-21\end{array}$ & $\begin{array}{l}\text { ted contri- } \\
\text { s to ODSX }\end{array}$ & $\begin{array}{l}\text { Calculat- } \\
\text { ed ranges } \\
\text { of contri- } \\
\text { butions } \\
\text { to } \\
\text { ODSX }\end{array}$ \\
\hline $\begin{array}{l}\mathrm{C}_{4} \mathrm{AF} \\
\mathrm{Na}_{2} \mathrm{O} \\
\mathrm{C}_{3} \mathrm{~A} / \mathrm{SO}_{3} \\
\mathrm{Air} \text { con- } \\
\text { tent.** }\end{array}$ & $\begin{array}{c}4 \text { to } 17 \\
0 \text { to } 0.75 \\
0.4 \text { to } 10.1 \\
0 \text { to } 10\end{array}$ & $\begin{array}{l}+0.00 \\
-0.00 \\
+0.00 \\
-0.00\end{array}$ & $\begin{array}{r}\text { Const. }=-0.00207 \\
+0.0018 \text { to }+0.0074 \\
0 \text { to }-0.0037 \\
+0.0004 \text { to }+0.0097 \\
0 \text { to }-0.0066\end{array}$ & $\begin{array}{l}0.0056 \\
0.0037 \\
0.0093 \\
0.0066\end{array}$ \\
\hline $\begin{array}{l}\text { APF } \\
\text { Los } \\
\text { SrO } \\
\text { Li** }\end{array}$ & $\begin{array}{c}* 2500 \text { to } 5500 \\
0.3 \text { to } 3.3 \\
0 \text { to } 0.4 \\
0 \text { to } 0.02 \\
0 \text { to } 0.01\end{array}$ & $\begin{array}{l}+0.00000183 \\
-0.00182 \\
+0.0113 \\
-0.1529 \\
-0.3841\end{array}$ & $\begin{array}{r}+0.0046 \text { to }+0.0101 \\
-0.0005 \text { to }-0.00 \text { tio } \\
0 \text { to }+0.0045 \\
0 \text { to }-0.0030 \\
0 \text { to }-0.0038\end{array}$ & $\begin{array}{l}0.0055 \\
0.0055 \\
0.0045 \\
0.0030 \\
0.0038\end{array}$ \\
\hline
\end{tabular}

$* \mathrm{~cm}^{2} / \mathrm{g}$.

**Coefficient of doubtful significance as coef./s.d. ratio was less than 2 . to the residual-shrinkage values are presented in table 10-26. Increases in $\mathrm{C}_{4} \mathrm{AF}, \mathrm{C}_{3} \mathrm{~A} / \mathrm{SO}_{3}$, fineness, and possibly $\mathrm{SrO}$ were associated with greater residual shrinkage. Increases in $\mathrm{Na}_{2} \mathrm{O}$, loss on ignition, and $\mathrm{Li}$ were associated with decreases in the residual shrinkage. Of these, differences in $\mathrm{C}_{4} \mathrm{AF}, \mathrm{C}_{3} \mathrm{~A} / \mathrm{SO}_{3}$, and fineness had the greatest calculated effect on the ranges of the values for residual shrinkage. The air-content and $\mathrm{Rb}$, though of doubtful significance in eq 2 of table 10-25, may possibly be significant in eq 2 of table 10-24 where the $\mathrm{AE}$ cements were included.

TABLE 10-23. Frequency distribution of cements with respect to difference between the shrinkage and subsequent expansion of nominal $51 / 2$ bags of cement per cubic yard concretes with a $5 \pm 1$ in. clump $(A D S X)$

\begin{tabular}{|c|c|c|c|c|c|c|c|c|c|c|c|c|c|}
\hline \multirow{3}{*}{ Type cement } & \multicolumn{12}{|c|}{ Percentage shrinkage minus percentage expansion } & \multirow{3}{*}{ Total } \\
\hline & $\begin{array}{c}0.000 \\
\text { to } \\
0.002\end{array}$ & $\begin{array}{c}0.002 \\
\text { to } \\
0.004\end{array}$ & $\begin{array}{c}0.004 \\
\text { to } \\
0.006\end{array}$ & $\begin{array}{c}0.006 \\
\text { to } \\
0.008\end{array}$ & $\begin{array}{c}0.008 \\
\text { to } \\
0.010\end{array}$ & $\begin{array}{c}0.010 \\
\text { to } \\
0.012\end{array}$ & $\begin{array}{c}0.012 \\
\text { to } \\
0.014\end{array}$ & $\begin{array}{c}0.014 \\
\text { to } \\
0.016\end{array}$ & $\begin{array}{c}0.016 \\
\text { to } \\
0.018\end{array}$ & $\begin{array}{c}0.018 \\
\text { to } \\
0.020\end{array}$ & $\begin{array}{c}0.020 \\
\text { to } \\
0.022\end{array}$ & $\begin{array}{c}0.022 \\
\text { to } \\
0.024\end{array}$ & \\
\hline & \multicolumn{12}{|c|}{ Number of cements } & \\
\hline 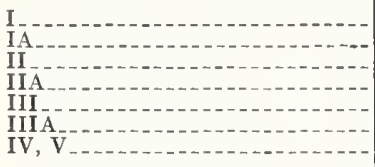 & 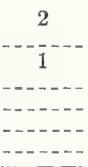 & 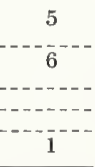 & $\frac{10}{8}$ & $\begin{array}{r}11 \\
1 \\
9 \\
3 \\
-1- \\
-4\end{array}$ & $\begin{array}{r}13 \\
1 \\
18 \\
2 \\
1 \\
1 \\
5\end{array}$ & $\frac{17}{11}$ & 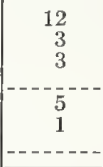 & 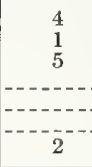 & \begin{tabular}{c}
1 \\
1 \\
5 \\
\hdashline--- \\
\hdashline 1
\end{tabular} & 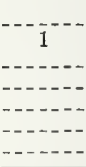 & 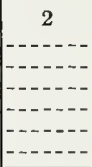 & 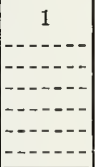 & $\begin{array}{r}78 \\
8 \\
66 \\
2 \\
20 \\
3 \\
15\end{array}$ \\
\hline Total & 3 & 12 & 22 & 28 & 41 & 38 & 24 & 12 & 8 & 1 & 2 & 1 & 192 \\
\hline
\end{tabular}

TABLE 10-24. Coefficients for equations for $A E+N A E$ cements relating the difference be days water storage $\left(A D S X=A S H R-A E X P\right.$ ) of concretes having a nominal $5 \frac{1}{2}$ bags

\begin{tabular}{|c|c|c|c|c|c|c|c|}
\hline Equation & Note & & Const. & $\mathrm{C}_{4} \mathrm{~A} \mathrm{~F}$ & $\mathrm{Na}_{2} \mathrm{O}$ & $\mathrm{C}_{3} \mathrm{~A} / \mathrm{SO}_{3}$ & $\mathrm{SO}_{3}$ \\
\hline 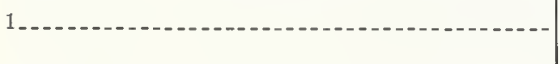 & (1) & $\begin{array}{l}\text { ADSX } \\
\text { s.d. }\end{array}$ & $\begin{array}{l}=-0.00673 \\
=(0.00318)\end{array}$ & $\begin{array}{c}+0.000539 \\
(0.000142)\end{array}$ & $\begin{array}{c}-0.00364 \\
(0.00161)\end{array}$ & $\begin{array}{c}+0.00106 \\
(0.00020)\end{array}$ & 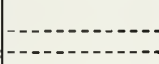 \\
\hline - - & (1) & $\begin{array}{l}\text { ADSX } \\
\text { s.d. }\end{array}$ & $\begin{array}{l}=-0.00519 \\
=(0.00304)\end{array}$ & $\begin{array}{r}+0.000552 \\
(0.000136)\end{array}$ & $\begin{array}{c}-0.00402 \\
(0.00176)\end{array}$ & $\begin{array}{r}+0.00080 \\
(0.00020)\end{array}$ & $\ldots$ \\
\hline $2 A_{-}$ & $\left({ }^{2}\right)$ & $\begin{array}{l}\text { ADSX (odd) } \\
\text { s.d. }\end{array}$ & $\begin{array}{l}=-0.00423 \\
=(0.00466)\end{array}$ & $\begin{array}{r}+0.000498 \\
(0.000199)\end{array}$ & $\begin{array}{c}-0.00399 \\
(0.00260)\end{array}$ & $\begin{array}{c}+0.00086 \\
(0.00031)\end{array}$ & \\
\hline 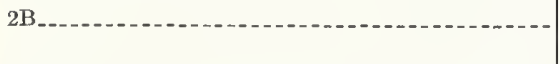 & $\left(3^{3}\right)$ & $\begin{array}{l}\text { ADSX (even) } \\
\text { s.d. }\end{array}$ & $\begin{aligned} & =-0.00545 \\
& =(0.00436)\end{aligned}$ & $\begin{array}{c}+0.000560 \\
(0.000200)\end{array}$ & $\begin{array}{c}-0.00412 \\
(0.00253)\end{array}$ & $\begin{array}{c}-0.00071 \\
(0.00031)\end{array}$ & \\
\hline 3. & (1) & $\begin{array}{l}\operatorname{ADSX} \\
\text { s.d. }\end{array}$ & $\begin{array}{l}=-0.00573 \\
=(0.00110)\end{array}$ & 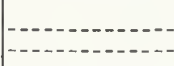 & 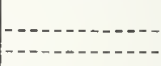 & - $-1-1-1$ & \\
\hline 4 & $(1)$ & $\begin{array}{l}\text { ADSX } \\
\text { s.d. }\end{array}$ & $\begin{array}{l}=-0.00798 \\
=(0.00187)\end{array}$ & $\begin{array}{c}+0.000098 \\
(0.000088)\end{array}$ & 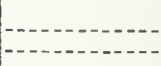 & --- & $\begin{array}{c}+0.00112 \\
(0.00057)\end{array}$ \\
\hline 5 & (1) & $\begin{array}{l}\text { ADSX } \\
\text { s.d. }\end{array}$ & $\begin{array}{l}=-0.00729 \\
=\quad(0.00184)\end{array}$ & $\begin{array}{r}+0.000175 \\
(0.000086)\end{array}$ & $-\ldots$ & & $\begin{array}{c}+0.00080 \\
(0.00057)\end{array}$ \\
\hline $5 \mathrm{~A}_{-\ldots}$ & $\left({ }^{2}\right)$ & $\begin{array}{l}\text { ADSX (odd) } \\
\text { s.d. }\end{array}$ & $\begin{array}{l}=-0.00708 \\
=(0.00279)\end{array}$ & $\begin{array}{r}* 0.000106 \\
(0.000125)\end{array}$ & -- & & $\begin{array}{r}+0.00133 \\
(0.00076)\end{array}$ \\
\hline $5 \mathrm{~B}_{-} \ldots \ldots+\ldots$ & $\left({ }^{3}\right)$ & $\begin{array}{l}\text { ADSX (even) } \\
\text { s.d. }\end{array}$ & $\begin{array}{l}=-0.00742 \\
=(0.00254)\end{array}$ & $\begin{array}{c}+0.000212 \\
(0.000123)\end{array}$ & & & $\begin{array}{c}+0.00254 \\
(0.00088)\end{array}$ \\
\hline
\end{tabular}

${ }^{1} 171$ cements; $\mathrm{Avg}=0.00807$; S.D. $=0.00384$.

286 cements. 


\subsection{Ratio of Percentage Expansion Divided by the Percentage Shrinkage}

a. Ratio of Expansion Divided by the Shrinkage of Series $O$ Concretes Made with a Water/Cement Ratio of 0.635 (OREX = OEXP/OSHR)

The frequency distribution of the cements with respect to the ratio of the expansion divided by the shrinkage of Series 0 concretes of $\mathrm{AE}+$ NAE cements is presented in table 1027. Although there was a considerable range of values for the ratio, and an overlapping of the values for the cements of the different types, the averages of the ratios of the airentraining cements were close to the averages of the NAE cements.

Equations relating the expansion-shrinkage ratio of Series 0 concretes to various independent variables are presented in table 10-28. Equation 1 indicates that this ratio is significantly related to the shrinkage of the specimens when dried in laboratory air for 56 days (see table 10 44). Use of the independent variables associated with the chemical composition of the cements, as in eq 2, produced an equivalent S.D. value. Using the chemical-composition variables and the shrinkage in eq 3 resulted in a significant reduction in the S.D. value (see table 10-44). Equations 4, 6, and 7, calculated with $\mathrm{C}_{3} \mathrm{~A}, \mathrm{Fe}_{2} \mathrm{O}_{3}$, and $\mathrm{Al}_{2} \mathrm{O}_{3}$ respectively in place of the $\mathrm{C}_{4} \mathrm{AF}$ of eq 3 , resulted in S.D. values which were close to that obtained in eq 3.

In eqs $2 \mathrm{~A}$ and $2 \mathrm{~B}$ for the "odds" and "evens" there were instances where the coef./s.d. ratios of $\mathrm{C}_{4} \mathrm{AF}$, and $\mathrm{MgO}$ were less than 1 . In equations using the "odds" and "evens" of the equations $3,4,5,6$, and 7 , not presented in the table, $\mathrm{C}_{4} \mathrm{AF}, \mathrm{Fe}_{2} \mathrm{O}_{3}, \mathrm{C}_{3} \mathrm{~A}, \mathrm{Al}_{2} \mathrm{O}_{3}, \mathrm{Na}_{2} \mathrm{O}, \mathrm{MgO}, \mathrm{Li}$, and $\mathrm{Ba}$, all had coef./s.d. ratios less than one in one or the other or both of the equations for these smaller groups of cements.

A similar series of equations relating the expansion/shrinkage ratios of concretes made of the NAE cements to various independent variables is presented in table 10-29. The independent variables associated with the differences in the ratios, their probable significance, and the reduction in variance resulting from their use in the multivariable equations were in reasonable agreement with those of the preceding table 10-28 where the $\mathrm{AE}$ cements were included.

Using the coefficients of the independent variables of eq 2 , table $10-29$, and their ranges of values, computations were made of the calculated contributions to the expansion/shrinkage ratio, as well as the calculated ranges of these contributions. These calculated values are presented in table 10-30. Increases in $\mathrm{Na}_{2} \mathrm{O}, \mathrm{Li}$, and $\mathrm{Rb}$ were associated with increases of the expansion/shrinkage ratio. Increase in $\mathrm{SrO}$ associated with a decrease in the ratio, whereas $\mathrm{C}_{4} \mathrm{AF}, \mathrm{MgO}$, and $\mathrm{Ba}$ had coef./s.d. ratios of doubtful significance.

b. Ratio of Expansion Divided by the Shrinkage of Con cretes made having a Slump of $5 \pm 1$ in (AREX $=$ AEXP/ASHR)

The frequency distribution of the cements with respect to the expansion/shrinkage ratios of Series A concretes is presented in table $10-31$. The range of values for the ratio was rather large and there was an overlapping of the values of the cements of the different types.

Equations relating the expansion/shrinkage ratio of the Series A concrete specimens made of $\mathrm{AE}+\mathrm{NAE}$ are presented in table 10-32. No relationship was found between the ratio and the water/cement ratio used in preparing the

tween the percentage shrinkage after 56 days drying and the percentage expansion after 28 of cement per cubic yard and a slump of $5 \pm 1 \mathrm{in}$., to various independent variables

\begin{tabular}{|c|c|c|c|c|c|c|c|c|c|}
\hline Air content & APF & Loss & $\mathrm{MgO}$ & $\mathrm{SrO}$ & $\mathrm{Li}$ & $\mathrm{Mn}$ & $\mathrm{Rb}$ & ASHR & S. D. \\
\hline $\begin{array}{c}+0.000338 \\
(0.000129)\end{array}$ & $\begin{array}{c}+0.00000237 \\
(0.00000059)\end{array}$ & $\begin{array}{c}-0.00186 \\
(0.00055)\end{array}$ & & & & & & & 0.00344 \\
\hline $\begin{array}{c}+0.000272 \\
(0.000122)\end{array}$ & $\begin{array}{c}+0.00000165 \\
(0.00000056)\end{array}$ & $\begin{array}{c}-0.00165 \\
(0.00052)\end{array}$ & $\mid$ & $\begin{array}{c}+0.0108 \\
(0.0031)\end{array}$ & $\begin{array}{c}-0.1714 \\
(0.0822)\end{array}$ & $\begin{array}{c}-0.00274 \\
(0.00208)\end{array}$ & $\begin{array}{c}-0.2812 \\
(0.1337)\end{array}$ & & 0.00323 \\
\hline $\begin{array}{c}+0.000299 \\
(0.000165)\end{array}$ & $\begin{array}{r}+0.00000185 \\
(0.00000094)\end{array}$ & $\begin{array}{c}-0.00146 \\
(0.00092)\end{array}$ & 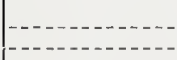 & $\begin{array}{c}+0.0094 \\
(0.0045)\end{array}$ & $\begin{array}{c}-0.2033 \\
(0.1179)\end{array}$ & $\begin{array}{r}-0.00662 \\
(0.00285)\end{array}$ & $\begin{array}{r}-0.2497 \\
(0.1719)\end{array}$ & & 0.00318 \\
\hline $\begin{array}{c}+0.000303 \\
(0.000196)\end{array}$ & $\begin{array}{c}+0.00000216 \\
(0.00000075)\end{array}$ & $\begin{array}{c}-0.00203 \\
(0.00073)\end{array}$ & & $\begin{array}{c}+0.0122 \\
(0.0048)\end{array}$ & $\begin{array}{r}-0.1410 \\
(0.1255)\end{array}$ & $\begin{array}{r}*+0.00191 \\
(0.00328)\end{array}$ & $\begin{array}{c}-0.3311 \\
(0.2280)\end{array}$ & & 0.00340 \\
\hline-- & & & 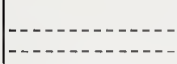 & & & & $2-1-2-12-1$ & $\begin{array}{r}+0.4933 \\
(0.0360)\end{array}$ & 0.00265 \\
\hline & & & $\begin{array}{r}-0.000512 \\
(0.000169)\end{array}$ & & & & & $\begin{array}{r}+0.5066 \\
(0.0351)\end{array}$ & 0.00257 \\
\hline & & & $\begin{array}{r}-0.000370 \\
(0.000169)\end{array}$ & $\begin{array}{r}+0.0047 \\
(0.0023)\end{array}$ & $\begin{array}{r}-0.1459 \\
(0.0573)\end{array}$ & $\begin{array}{c}-0.00305 \\
(0.00162)\end{array}$ & $\begin{array}{r}-0.2592 \\
(0.1005)\end{array}$ & $\begin{array}{r}+0.4705 \\
(0.0364)\end{array}$ & 0.00246 \\
\hline & & & $\begin{array}{c}-0.000329 \\
(0.000250)\end{array}$ & $\begin{array}{r}+0.0051 \\
(0.0032)\end{array}$ & $\begin{array}{c}-0.1824 \\
(0.0828)\end{array}$ & $\begin{array}{c}-0.00640 \\
(0.00224)\end{array}$ & $\begin{array}{r}-0.2660 \\
(0.1284)\end{array}$ & $\begin{array}{r}+0.4568 \\
(0.0544)\end{array}$ & 0.00241 \\
\hline & & & $\begin{array}{c}-0.000352 \\
(0.000245)\end{array}$ & $\begin{array}{r}+0.0034 \\
(0.0033)\end{array}$ & $\begin{array}{r}-0.0965 \\
(0.0837)\end{array}$ & $\begin{array}{r}*+0.00027 \\
(0.00241)\end{array}$ & $\begin{array}{r}-0.2634 \\
(0.1667)\end{array}$ & $\begin{array}{r}+0.4947 \\
(0.0505)\end{array}$ & 0.00251 \\
\hline
\end{tabular}


$\mathrm{T}_{\triangle \mathrm{BLE}}$ 10-25. Coefficients for equations for NAE cements relating the difference between water storage ( $A D S X=A S H R-A E X P)$ of concretes having a nominal $51 / 2$ bags of ce

\begin{tabular}{|c|c|c|c|c|c|c|c|}
\hline Equation & Note & & Const. & $\mathrm{C}_{4} \mathrm{AF}$ & $\mathrm{Na}_{2} \mathrm{O}$ & $\mathrm{C} 3 \mathrm{~A} / \mathrm{SO}_{3}$ & $\mathrm{SO}_{3}$ \\
\hline 1 & (1) & $\begin{array}{l}\text { ADSX } \\
\text { s.d. }\end{array}$ & $\begin{array}{l}=-0.00486 \\
=(0.00319)\end{array}$ & $\begin{array}{c}+0.00051 \\
(0.00014)\end{array}$ & $\begin{array}{c}-0.00365 \\
(0.00159)\end{array}$ & $\begin{array}{c}+0.00098 \\
(0.00020)\end{array}$ & 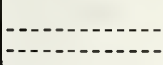 \\
\hline $2 \ldots$ & (1) & $\begin{array}{l}\text { ADsX } \\
\text { s.d. }\end{array}$ & $\begin{array}{l}=-0.00424 \\
=(0.00310)\end{array}$ & $\begin{array}{c}+0.00054 \\
(0.00014)\end{array}$ & $\begin{array}{c}-0.00396 \\
(0.00177)\end{array}$ & $\begin{array}{c}+0.00078 \\
(0.00021)\end{array}$ & 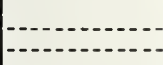 \\
\hline $2 A$ & (2) & $\begin{array}{l}\text { ADSX (odd) } \\
\text { s.d. }\end{array}$ & $\begin{array}{l}=-0.00514 \\
=(0.00524)\end{array}$ & $\begin{array}{c}+0.00058 \\
(0.00023)\end{array}$ & $\begin{array}{c}-0.00428 \\
(0.00287)\end{array}$ & $\begin{array}{c}+0.00055 \\
(0.00034)\end{array}$ & 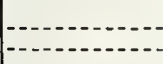 \\
\hline $2 \mathrm{~B}$ & (3) & $\begin{array}{l}\text { ADSX (even) } \\
\text { s.d. }\end{array}$ & $\begin{array}{l}=-0.00272 \\
=(0.00399)\end{array}$ & $\begin{array}{c}+0.00046 \\
(0.00018)\end{array}$ & $\begin{array}{c}-0.00346 \\
(0.00239)\end{array}$ & $\begin{array}{c}+0.00091 \\
(0.00028)\end{array}$ & 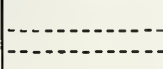 \\
\hline $3 \ldots \ldots$ & (1) & $\begin{array}{l}\text { ADSX } \\
\text { s.d. }\end{array}$ & $\begin{array}{l}=-0.00547 \\
=(0.00114)\end{array}$ & & & & \\
\hline $4 \ldots \ldots$ & (1) & $\begin{array}{l}\text { ADSX } \\
\text { s.d. }\end{array}$ & $\begin{array}{l}=-0.00735 \\
=(0.00199)\end{array}$ & $+\underset{(0.000089)}{0.000119}$ & & & $\begin{array}{l}+0.00116 \\
(0.00059)\end{array}$ \\
\hline 5... & (1) & $\begin{array}{l}\text { ADSX } \\
\text { s.d. }\end{array}$ & $\begin{array}{l}=-0.00760 \\
=(0.00193)\end{array}$ & $\begin{array}{c}+0.000199 \\
(0.000087)\end{array}$ & & & $\begin{array}{c}+0.00094 \\
(0.00059)\end{array}$ \\
\hline $\mathbf{5} \mathrm{A}$ & (2) & $\begin{array}{l}\text { ADSX (odd) } \\
\text { s.d. }\end{array}$ & $\begin{array}{l}=-0.00969 \\
=(0.00285)\end{array}$ & $\begin{array}{c}+0.000318 \\
(0.000146)\end{array}$ & & & $\begin{array}{c}+0.00166 \\
(0.00085)\end{array}$ \\
\hline $5 B_{--.}$ & (a) & $\begin{array}{l}\text { ADSX (even) } \\
\text { s.d. }\end{array}$ & $\begin{array}{l}=-0.00682 \\
=(0.00282)\end{array}$ & $\begin{array}{c}+0.000146 \\
(0.000108)\end{array}$ & & & $\begin{array}{r}*+0.00084 \\
(0.00084)\end{array}$ \\
\hline
\end{tabular}

1159 eements; $\mathrm{Avg}=0.00886$; S.D. $=0.00376$.

280 cements.

379 cements.

* Coef./s.d. ratio less than 1.

TABLE 10-26. Calculated contributions to the percentage shrinkage after 56 days drying minus the percentage expansion after 28 days in water of concretes having a nominal $51 / 2$ bags of cement per cubic yard and a slump of $5 \pm 1$ in., and the calculated ranges of such contributions ( $A D S X=A S H R-$ $A E X P$ )

\begin{tabular}{|c|c|c|c|c|}
\hline $\begin{array}{c}\text { Inde- } \\
\text { pendent } \\
\text { variables }\end{array}$ & $\begin{array}{l}\text { Range of } \\
\text { variables } \\
\text { (percent) }\end{array}$ & $\begin{array}{l}\text { Coefficients } \\
\text { from eq (2) } \\
\text { table } 10-25\end{array}$ & $\begin{array}{l}\text { Calculated contri- } \\
\text { butions to ADSX }\end{array}$ & $\begin{array}{l}\text { Calculat- } \\
\text { ed ranges } \\
\text { of contri- } \\
\text { butions } \\
\text { to } \\
\text { ADSX }\end{array}$ \\
\hline 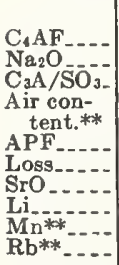 & $\begin{array}{c}4 \text { to } 17 \\
0 \text { to } 0.75 \\
0.4 \text { to } 10.1 \\
0 \text { to } 13 \\
* 2500 \text { to } 5500 \\
0.3 \text { to } 3.3 \\
0 \text { to } 0.4 \\
0 \text { to } 0.02 \\
0 \text { to } 1.0 \\
0 \text { to } 0.01\end{array}$ & $\begin{array}{l}+0.00054 \\
-0.00396 \\
+0.00078 \\
-0.000336 \\
+0.00000218 \\
-0.00188 \\
+0.0089 \\
-0.1431 \\
-0.00294 \\
-0.1861\end{array}$ & $\begin{array}{r}\text { Const. }=-0.00424 \\
+0.0022 \text { to }+0.0092 \\
0 \text { to }-0.0030 \\
+0.0003 \text { to }+0.0079 \\
0 \text { to }-0.0044 \\
+0.0054 \text { to }+0.0120 \\
-0.0006 \text { to }-0.0062 \\
0 \text { to }+0.0036 \\
0 \text { to }-0.0029 \\
0 \text { to }-0.0029 \\
0 \text { to }-0.0019\end{array}$ & $\begin{array}{l}0.0070 \\
0.0030 \\
0.0076 \\
0.0044 \\
\\
0.0066 \\
0.0056 \\
0.0036 \\
0.0029 \\
0.0029 \\
0.0019\end{array}$ \\
\hline
\end{tabular}

* ${ }^{*} \mathrm{~cm}^{2} / \mathrm{g}$. concretes, see eq 1 . Using commonly determined variables in eq 2 resulted in a significant reduction in the S.D. value, but in eq 4 the indication of reduction was significant at the 5percent probability level (see table 10-44). The additional use of the trace elements $\mathrm{Li}, \mathrm{SrO}$, $\mathrm{Mn}, \mathrm{Rb}, \mathrm{Zn}$, and $\mathrm{Ba}$ in eqs 3 and 5 resulted in significant reductions in the S.D. values although norie of the individual variables except SrO had high coef./s.d. ratios (see table 1044). The coef./s.d. ratios of $\mathrm{C}_{3} \mathrm{~A}, \mathrm{C}_{2} \mathrm{~S}$, Wagn, $\mathrm{Mn}, \mathrm{Zn}$, and $\mathrm{Ba}$ were less than 1 in one or the other of the pairs of equations for the "odds" and "evens", eqs $3 \mathrm{~A}, 3 \mathrm{~B}$, or 5A, 5B. Equation 6 gives a significant indication that the expansion/shrinkage ratio was associated with the shrinkage values of the concretes. The use of other independent variables in addition to ASHR in eq 7 resulted in a further significant reduction in the S.D. value (see table 10-44). 
the percentage shrinkage after 56 days drying and the percentage expansion after 28 days ment per cubic yard and a slump of $5 \pm 1$ in., to various independent variables

\begin{tabular}{|c|c|c|c|c|c|c|c|c|c|}
\hline Air content & APF & Loss & $\mathrm{MgO}$ & $\mathrm{SrO}$ & $\mathbf{L i}$ & $\mathrm{Mn}$ & $\mathrm{Rb}$ & ASHR & S.D. \\
\hline $\begin{array}{c}-0.000423 \\
(0.000308)\end{array}$ & $\begin{array}{c}+0.00000243 \\
(0.00000059)\end{array}$ & $\begin{array}{r}-0.00214 \\
(0.00055)\end{array}$ & $-\cdots$ & - & $-\cdots$ & $-\cdots$ & 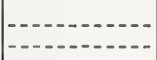 & and & 0.00333 \\
\hline $\begin{array}{c}-0.000336 \\
(0.000309)\end{array}$ & $\begin{array}{r}+0.00000218 \\
(0.00000057)\end{array}$ & $\begin{array}{r}-0.00188 \\
(0.00053)\end{array}$ & 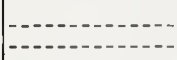 & $\begin{array}{c}+0.0089 \\
(0.0032)\end{array}$ & $\begin{array}{c}-0.1431 \\
(0.0834)\end{array}$ & $\begin{array}{r}-0.00294 \\
(0.00213)\end{array}$ & $\begin{array}{r}-0.1861 \\
(0.1375)\end{array}$ & $-\infty$ & 0.00320 \\
\hline $\begin{array}{r}-0.000553 \\
(0.000541)\end{array}$ & $\begin{array}{c}+0.00000269 \\
(0.00000103)\end{array}$ & $\begin{array}{r}-0.00211 \\
(0.00094)\end{array}$ & 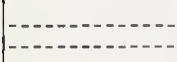 & $\begin{array}{c}+0.0106 \\
(0.0051)\end{array}$ & $\begin{array}{r}*-0.1217 \\
(0.1292)\end{array}$ & $\begin{array}{c}-0.00357 \\
(0.00290)\end{array}$ & $\begin{array}{r}*-0.1142 \\
(0.2071)\end{array}$ & $\ldots$ & 0.00352 \\
\hline $\begin{array}{r}* 0.000173 \\
(0.000402)\end{array}$ & $\begin{array}{c}+0.00000173 \\
(0.00000069)\end{array}$ & $\begin{array}{c}-0.00178 \\
(0.00066)\end{array}$ & $\mid----$ & $\begin{array}{c}+0.0067 \\
(0.0044)\end{array}$ & $\begin{array}{c}-0.1754 \\
(0.1221)\end{array}$ & $\begin{array}{c}-0.00389 \\
(0.00378)\end{array}$ & $\begin{array}{c}-0.3084 \\
(0.2034)\end{array}$ & $-\cdots$ & 0.00301 \\
\hline & & -- & --- & & & & & $\begin{array}{c}+0.4834 \\
(0.0378)\end{array}$ & 0.00264 \\
\hline $\begin{array}{c}-0.000321 \\
(0.000233)\end{array}$ & & -- & $\begin{array}{c}-0.000534 \\
(0.000172)\end{array}$ & & & & -- & $\begin{array}{c}+0.4925 \\
(0.0368)\end{array}$ & 0.00254 \\
\hline & & & $\begin{array}{c}-0.000399 \\
(0.000174)\end{array}$ & $\begin{array}{r}+0.0034 \\
(0.0023)\end{array}$ & $\begin{array}{r}-0.1473 \\
(0.0573)\end{array}$ & $\begin{array}{r}-0.00315 \\
(0.00166)\end{array}$ & $\begin{array}{r}-0.2462 \\
(0.1024)\end{array}$ & $\begin{array}{r}+0.4715 \\
(0.0382)\end{array}$ & 0.00245 \\
\hline & & & $\begin{array}{r}*+0.000092 \\
(0.000286)\end{array}$ & $\begin{array}{r}+0.0051 \\
(0.0036)\end{array}$ & $\begin{array}{r}-0.1937 \\
(0.0843)\end{array}$ & $\begin{array}{r}-0.00557 \\
(0.00228)\end{array}$ & $\begin{array}{r}-0.3112 \\
(0.1477)\end{array}$ & $\begin{array}{r}+0.4786 \\
(0.0562)\end{array}$ & 0.00267 \\
\hline & & & $\begin{array}{c}-0.000647 \\
(0.000216)\end{array}$ & $\begin{array}{r}*+0.0016 \\
(0.0031)\end{array}$ & $\begin{array}{r}-0.1108 \\
(0.0802)\end{array}$ & $\begin{array}{r}*+0.00046 \\
(0.00282)\end{array}$ & $\begin{array}{c}-0.2503 \\
(0.1488)\end{array}$ & $\begin{array}{c}+0.4767 \\
(0.0543)\end{array}$ & 0.00223 \\
\hline
\end{tabular}

TABLE 10-27. Frequency distribution of cements with respect to ratio, percentage expansion divided by percentage shrinkage, for con cretes having a nominal $51 / 2$ bags of cement per cubic yard and a water-cement ratio of $0.635(O R E X=O E X P / O S H R)$

\begin{tabular}{|c|c|c|c|c|c|c|c|c|c|c|c|c|c|c|c|}
\hline \multirow{3}{*}{ Type cement } & \multicolumn{14}{|c|}{ Ratio } & \multirow{3}{*}{ Total } \\
\hline & $\begin{array}{c}0.35 \\
\text { to } \\
0.40\end{array}$ & $\begin{array}{c}0.40 \\
\text { to } \\
0.45\end{array}$ & $\begin{array}{c}0.45 \\
\text { to } \\
0.50\end{array}$ & $\begin{array}{c}0.50 \\
\text { to } \\
0.55\end{array}$ & $\begin{array}{c}0.55 \\
\text { to } \\
0.60\end{array}$ & $\begin{array}{c}0.60 \\
\text { to } \\
0.65\end{array}$ & $\begin{array}{c}0.65 \\
\text { to } \\
0.70\end{array}$ & $\begin{array}{c}0.70 \\
\text { to } \\
0.75\end{array}$ & $\begin{array}{c}0.75 \\
\text { to } \\
0.80\end{array}$ & $\begin{array}{c}0.80 \\
\text { to } \\
0.85\end{array}$ & $\begin{array}{c}0.85 \\
\text { to } \\
0.90\end{array}$ & $\begin{array}{c}0.90 \\
\text { to } \\
0.95\end{array}$ & $\begin{array}{c}0.95 \\
\text { to } \\
1.00\end{array}$ & $\begin{array}{l}1.00 \\
\text { and } \\
\text { over }\end{array}$ & \\
\hline & \multicolumn{14}{|c|}{ Number of cements } & \\
\hline 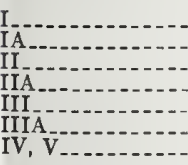 & 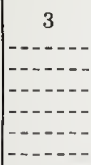 & 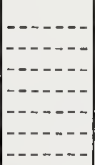 & 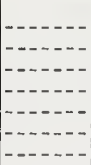 & $\mid \begin{array}{c}1 \\
-\cdots \\
---- \\
-\cdots--- \\
-\cdots---\end{array}$ & $\begin{array}{c}6 \\
2 \\
9 \\
1 \\
2\end{array}$ & $\begin{array}{r}15 \\
3 \\
12 \\
2 \\
6 \\
1 \\
5\end{array}$ & $\begin{array}{c}18 \\
18 \\
4 \\
1 \\
2\end{array}$ & $\begin{array}{r}14 \\
1 \\
8 \\
4 \\
3\end{array}$ & $\begin{array}{r}14 \\
2 \\
5 \\
1 \\
2\end{array}$ & $\frac{7}{7}$ & 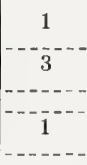 & 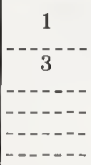 & 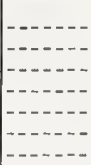 & 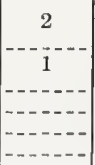 & $\begin{array}{r}82 \\
8 \\
68 \\
2 \\
20 \\
3 \\
15\end{array}$ \\
\hline Total & 3 & 0 & 0 & 3 & 20 & 44 & 43 & 30 & 24 & 19 & 5 & 4 & 0 & 3 & 198 \\
\hline
\end{tabular}




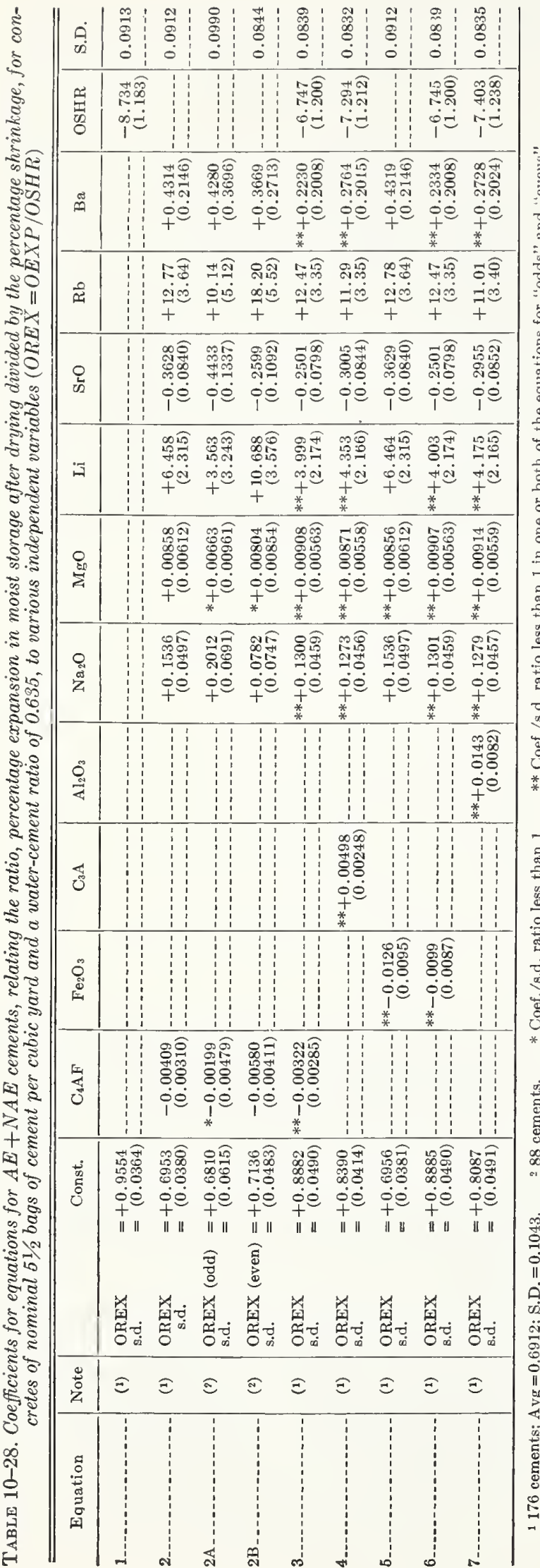

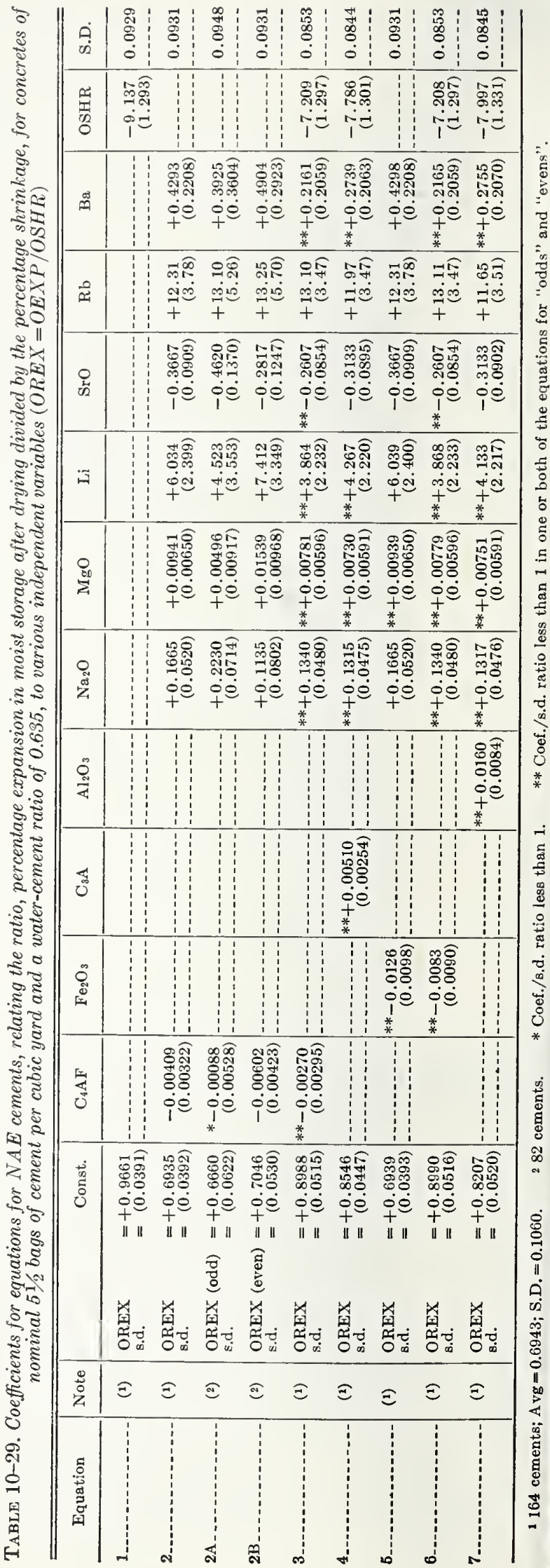


TABLE 10-30. Calculated contributions to the ratio, percentage expansion after 28 days in water divided by percentage shrinkage after 56 days of drying, for concretes having a nominal $51 / 2$ bags of cement per cubic yard and a water-cement ratio of 0.695 , and the calculated ranges of such contributions (OREX $=O E X P / O S H R$ )

\begin{tabular}{|c|c|c|c|c|}
\hline $\begin{array}{c}\text { Inde- } \\
\text { pendent } \\
\text { variables }\end{array}$ & $\begin{array}{l}\text { Range of } \\
\text { variables } \\
\text { (percent) }\end{array}$ & $\begin{array}{l}\text { Coefficients } \\
\text { from eq (2) } \\
\text { table } 10-29\end{array}$ & $\begin{array}{l}\text { Calculated contri- } \\
\text { butions to OREX }\end{array}$ & $\begin{array}{l}\text { Calculat- } \\
\text { ed ranges } \\
\text { of contri- } \\
\text { butions } \\
\text { to } \\
\text { OREX }\end{array}$ \\
\hline 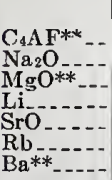 & $\begin{array}{l}4 \text { to } 17 \\
0 \text { to } 0.75 \\
0 \text { to } 5.0 \\
0 \text { to } 0.02 \\
0 \text { to } 0.4 \\
0 \text { to } 0.01 \\
0 \text { to } 0.2\end{array}$ & $\begin{array}{l}-0.00409 \\
+0.1665 \\
+0.00941 \\
+6.034 \\
-0.3667 \\
+12.31 \\
+0.4293\end{array}$ & $\begin{array}{r}\text { Const. }=+0.6935 \\
-0.016 \text { to }-0.069 \\
0 \text { to }+0.125 \\
0 \text { to }+0.047 \\
0 \text { to }+0.121 \\
0 \text { to }-0.147 \\
0 \text { to }+0.123 \\
0 \text { to }+0.086\end{array}$ & $\begin{array}{l}0.051 \\
0.125 \\
0.047 \\
0.121 \\
0.147 \\
0.123 \\
0.086\end{array}$ \\
\hline
\end{tabular}

**Coefficient of doubtful significance as coef./s.d. ratio was less than 2 .
A corresponding series of equations for the NAE cements is presented in table 10-33 indicating the variables which were associated with the expansion/shrinkage ratios of the Series A concretes. The equations presented in table 1033 are in reasonable agreement with those presented in the previous table 10-32 where the AE cements were included in the calculated multivariable equations. (see also table 10-44).

Using the independent variables of eq 3 of table 10-33 and the ranges of these variables, calculations were made of the calculated contributions and ranges of contributions to the expansion/shrinkage ratios. The results of these calculations are presented in table 10-34. The coef./s.d. ratios of $\mathrm{C}_{3} \mathrm{~A}, \mathrm{C}_{2} \mathrm{~S}, \mathrm{Rb}, \mathrm{Zn}$, and $\mathrm{Ba}$ were all less than 2 in eq 3 of table 10-33, and

TABLE 10-31. Frequency distribution of cements with respect to the ratio, percentage expansion divided by the percentage shrinkage for concretes having a nominal $51 / 2$ bags of cement per cubic yard and a slump of $5 \pm 1$ in. $(A R E X=A E X P / A S H R)$

\begin{tabular}{|c|c|c|c|c|c|c|c|c|c|c|c|c|c|}
\hline \multirow{3}{*}{ Type cement } & \multicolumn{12}{|c|}{ Ratio } & \multirow{3}{*}{ Total } \\
\hline & $\begin{array}{c}0.40 \\
\text { to } \\
0.45\end{array}$ & $\begin{array}{c}0.45 \\
\text { to } \\
0.50\end{array}$ & $\begin{array}{c}0.50 \\
\text { to } \\
0.55\end{array}$ & $\begin{array}{c}0.55 \\
\text { to } \\
0.60\end{array}$ & $\begin{array}{c}0.60 \\
\text { to } \\
0.65\end{array}$ & $\begin{array}{c}065 \\
\text { to } \\
0.70\end{array}$ & $\begin{array}{c}0.70 \\
\text { to } \\
0.75\end{array}$ & $\begin{array}{c}0.75 \\
\text { to } \\
0.80\end{array}$ & $\begin{array}{c}0.80 \\
\text { to } \\
0.85\end{array}$ & $\begin{array}{c}0.85 \\
\text { to } \\
0.90\end{array}$ & $\begin{array}{c}0.90 \\
\text { to } \\
0.95\end{array}$ & $\begin{array}{c}0.95 \\
\text { to } \\
1.00\end{array}$ & \\
\hline & \multicolumn{12}{|c|}{ Number of cements } & \\
\hline 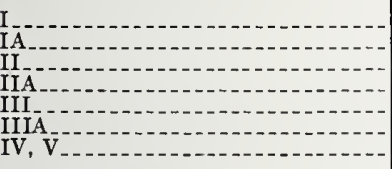 & 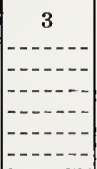 & 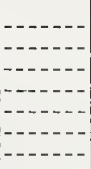 & $\mid \begin{array}{r}2 \\
2 \\
2 \\
-\cdots-- \\
\hdashline---- \\
\hdashline----\end{array}$ & 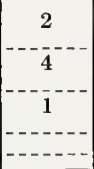 & $\begin{array}{r}13 \\
3 \\
9 \\
-3 \\
1 \\
4\end{array}$ & $\begin{array}{r}15 \\
1 \\
19 \\
10 \\
1 \\
4\end{array}$ & $\begin{array}{r}16 \\
13 \\
1 \\
2 \\
1 \\
4\end{array}$ & $\begin{array}{r}10 \\
2 \\
6 \\
1 \\
2 \\
2\end{array}$ & $\begin{array}{c}8 \\
-\frac{5}{5} \\
-1\end{array}$ & $\begin{array}{c}4 \\
-\frac{3}{1} \\
--\cdot\end{array}$ & 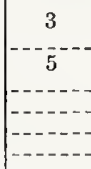 & 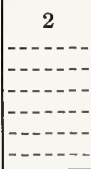 & $\begin{array}{r}78 \\
8 \\
66 \\
2 \\
20 \\
3 \\
15\end{array}$ \\
\hline Total & 3 & 0 & 6 & 7 & 33 & 50 & $37^{\circ}$ & 23 & 14 & 9 & 8 & 2 & 192 \\
\hline
\end{tabular}

of the other independent variables all but $\mathrm{MgO}$ had coef./s.d. ratios between 2 and $3 . \mathrm{MgO}$ had a coef./s.d. ratio of less than 1 in eq $3 \mathrm{~A}$ for one of the smaller groups of cements (the odds). There is a significant indication then, than an increase of the expansion/shrinkage ratio may be associated with an increase in $\mathrm{Na}_{2} \mathrm{O}, \mathrm{MgO}$, $\mathrm{Li}$, and $\mathrm{Mn}$. An increase in the expansion/ shrinkage ratio may possibly also be associated with decreasing values for $\mathrm{C}_{4} \mathrm{AF}$, fineness, and SrO.

\subsection{The ratio of the Residual Shrinkage after Rewetting to the Initial Shrinkage (OREX and AREX)}

The frequency distributions of the cements with respect to the ratio (OSHR-OEXP)/ OSHR and (ASHR-AEXP/ASHR are presented in tables 10-35 and 10-36 for the Series $\mathrm{O}$ and Series A concretes respectively. There was a considerable range of ratios in each of the tables and an overlapping of the values for the cements of different types.

Equations are presented in table 10-37 indicating the independent variables having a coef./s.d. ratio greater than 1 which may be associated with the (residual shrinkage divided by the shrinkage) ratios (OREX and $A R E X)$ for both $\mathrm{AE}+\mathrm{NAE}$ and the NAE cements. In equations for OEXR, none of the major potential compounds or major oxides had coef./s.d. ratios greater than 1 when used in multivariable equations with other independent variables. None of the other independent variables in eqs 1 and 2 except $\mathrm{Na}_{2} \mathrm{O}$ and $\mathrm{SrO}$ had coef./s.d. ratios greater than 3 . Only $\mathrm{SrO}$ had a coef./s.d. ratio greater than 3 in the two equations for the Series A concretes, eqs 3 and 4 . As indicated in table 10-44, there was a highly significant reduction in variance with each of the four equations of table 10-37.

The calculated contributions to the OEXR ratio, and estimated ranges of these contributions, are presented in table 10-38 for the Series $\mathrm{O}$ concretes. Increases in $\mathrm{SrO}$ and possibly $\mathrm{Pb}$ were associated with increases in the ratio. Increases in $\mathrm{Na}_{2} \mathrm{O}$, and possibly $\mathrm{SO}_{3}, \mathrm{Li}$, and $\mathrm{Rb}$ were associated with decreases in the ratio. The effect of the variables $\mathrm{MgO}, \mathrm{Ba}, \mathrm{V}$, and $\mathrm{P}$ were of doubtful significance. 
TABLE 10-32. Coefficients for equations for $A E \& N A E$ cements, relating the ratio, per bags of cement per cubic yard and a slump of $5 \pm 1$ in. Specimens were moist cured for 2 weeks, then air dried

\begin{tabular}{|c|c|c|c|c|c|c|c|}
\hline Equation & Note & & Const. & $\mathrm{C}_{3} \mathrm{~A}$ & $\mathrm{C}_{2} \mathrm{~S}$ & $\mathrm{C}_{4} \mathrm{AF}$ & $\mathrm{Fe}_{2} \mathrm{O}_{3}$ \\
\hline $1 \ldots+\ldots$ & (1) & $\begin{array}{l}\text { AREX } \\
\text { s.d. }\end{array}$ & $\begin{array}{l}=+0.729 \\
=(0.189)\end{array}$ & 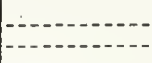 & & & \\
\hline 2 & (1) & $\begin{array}{l}\text { AREX } \\
\text { s.d. }\end{array}$ & $\begin{array}{l}=+1.039 \\
=(0.109)\end{array}$ & $\begin{array}{c}-0.0115 \\
(0.0032)\end{array}$ & $\begin{array}{c}-0.00161 \\
(0.00115)\end{array}$ & $\begin{array}{c}-0.00924 \\
(0.00368)\end{array}$ & 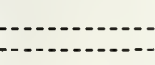 \\
\hline $3 \ldots$ & (1) & $\begin{array}{l}\text { AREX } \\
\text { s.d. }\end{array}$ & $\begin{array}{l}=+0.924 \\
=(0.108)\end{array}$ & $\begin{array}{c}-0.0046 \\
(0.0036)\end{array}$ & $\begin{array}{c}-0.00180 \\
(0.00109)\end{array}$ & $\begin{array}{c}-0.00830 \\
(0.00364)\end{array}$ & 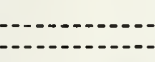 \\
\hline 3A & (2) & $\begin{array}{l}\text { AREX (odd) } \\
\text { s.d. }\end{array}$ & $\begin{array}{l}=+0.860 \\
=\quad(0.141)\end{array}$ & $\begin{array}{c}-0.0074 \\
(0.0047)\end{array}$ & $\begin{array}{r}*-0.00098 \\
(0.00129)\end{array}$ & $\begin{array}{c}-0.00883 \\
(0.00525)\end{array}$ & (n) \\
\hline $3 B_{-.}$ & (2) & $\begin{array}{l}\text { AREX (even) } \\
\text { s.d. }\end{array}$ & $\begin{array}{l}=+1.017 \\
=(0.185)\end{array}$ & $\begin{array}{c}*-0.0049 \\
(0.0064)\end{array}$ & $\begin{array}{c}-0.00280 \\
(0.00217)\end{array}$ & $\begin{array}{c}-0.00974 \\
(0.00561)\end{array}$ & 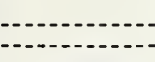 \\
\hline $4 \ldots$ & (1) & $\begin{array}{l}\text { AREX } \\
\text { s.d. }\end{array}$ & $\begin{array}{l}=+0.757 \\
=(0.067)\end{array}$ & & & & $\begin{array}{r}*-0.00554 \\
(0.00995)\end{array}$ \\
\hline $5 \ldots$ & (1) & $\begin{array}{l}\text { AREX } \\
\text { s.d. }\end{array}$ & $\begin{array}{l}=+0.787 \\
=(0.065)\end{array}$ & & & & $\begin{array}{c}-0.0191 \\
(0.0089)\end{array}$ \\
\hline $5 A$ & (2) & $\begin{array}{l}\text { AREX (odd) } \\
\text { s.d. }\end{array}$ & $\begin{array}{l}=+0.700 \\
=(0.096)\end{array}$ & & & & $\begin{array}{r}-0.0140 \\
(0.0134)\end{array}$ \\
\hline $5 B$ & (2) & $\begin{array}{l}\text { AREX (even) } \\
\text { s.d. }\end{array}$ & $\begin{array}{l}=+0.855 \\
=(0.094)\end{array}$ & & & - & $\begin{array}{c}-0.0244 \\
(0.0130)\end{array}$ \\
\hline 6.-- & (1) & $\begin{array}{l}\text { AREX } \\
\text { s.d. }\end{array}$ & $\begin{array}{l}=+0.899 \\
=(0.036)\end{array}$ & - & & - & - \\
\hline $7 .-$ & (1) & $\begin{array}{l}\text { AREX } \\
\text { s.d. }\end{array}$ & $\begin{array}{l}=+0.861 \\
=(0.045)\end{array}$ & - & $\ldots \ldots$ & $\begin{array}{c}* *-0.00467 \\
(0.00277)\end{array}$ & \\
\hline
\end{tabular}

3170 cements; $\mathrm{Avg}=0.7045 ;$ S.D. $=0.0941 . \quad 285$ cements.

$*$ Coef./8.d. ratio less than 1 .

** Coef./s.d. ratio less than 1 in equations for "odds" and "evens",

TABLE 10-33. Coefficients for equations for $N A E$ cements, relating the ratio, percentage cement per cubic yard and a slump of $5 \pm 1$ in to var Specimens were moist cured for 2 weeks, then air dried

\begin{tabular}{|c|c|c|c|c|c|c|c|}
\hline Equation & Note & & Const. & $\mathrm{C}_{3} \mathrm{~A}$ & $\mathrm{C}_{2} \mathrm{~S}$ & $\mathrm{C}_{4} \mathrm{AF}$ & $\mathrm{Fe}_{2} \mathrm{O}_{3}$ \\
\hline $1 \ldots$ & (1) & $\begin{array}{l}\text { AREX } \\
\text { s.d. }\end{array}$ & $\begin{array}{l}=+1.051 \\
=(0.256)\end{array}$ & & & & \\
\hline $2 \ldots$ & (1) & $\begin{array}{l}\text { AREX } \\
\text { s.d. }\end{array}$ & $\begin{array}{l}=+1.024 \\
=(0.110)\end{array}$ & $\begin{array}{c}-0.0101 \\
(0.0033)\end{array}$ & $\begin{array}{c}-0.00127 \\
(0.00117)\end{array}$ & $\begin{array}{c}-0.0099 \\
(0.0037)\end{array}$ & - \\
\hline 3 & (1) & $\begin{array}{l}\text { AREX } \\
\text { s.d. }\end{array}$ & $\begin{array}{l}=+0.928 \\
=(0.110)\end{array}$ & $\begin{array}{c}-0.0042 \\
(0.0037)\end{array}$ & $\begin{array}{c}-0.00154 \\
(0.00112)\end{array}$ & $\begin{array}{c}-0.0090 \\
(0.0037)\end{array}$ & $-\cdots$ \\
\hline 3A-- & (2) & $\begin{array}{l}\text { AREX (odd) } \\
\text { B.d. }\end{array}$ & $\begin{array}{l}=+1.108 \\
=(0.170)\end{array}$ & $\begin{array}{c}-0.0075 \\
(0.0055)\end{array}$ & $\begin{array}{c}-0.00186 \\
(0.00159)\end{array}$ & $\begin{array}{c}-0.0140 \\
(0.0061)\end{array}$ & - \\
\hline $3 B_{-}$ & (2) & $\begin{array}{l}\text { AREX (even) } \\
\text { s.d. }\end{array}$ & $\begin{array}{l}=+0.757 \\
=(0.152)\end{array}$ & $\begin{array}{c}*-0.0007 \\
(0.0053)\end{array}$ & $\begin{array}{c}*-0.00102 \\
(0.00177)\end{array}$ & $\begin{array}{c}-0.0054 \\
(0.0048)\end{array}$ & 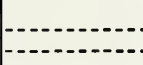 \\
\hline $4 \ldots$ & (1) & $\begin{array}{l}\text { AREX } \\
\text { s.d. }\end{array}$ & $\begin{array}{l}=+0.781 \\
=(0.068)\end{array}$ & & & & $\begin{array}{c}-0.0104 \\
(0.0095)\end{array}$ \\
\hline 5 & (1) & $\begin{array}{l}\text { AREX } \\
\text { s.d. }\end{array}$ & $\begin{array}{l}=+0.809 \\
=(0.068)\end{array}$ & & & & $\begin{array}{c}-0.0219 \\
(0.0091)\end{array}$ \\
\hline $5 A$ & (2) & $\begin{array}{l}\text { AREX (odd) } \\
\text { s.d. }\end{array}$ & $\begin{array}{l}=+0.913 \\
=(0.113)\end{array}$ & & & & $\begin{array}{c}-0.0298 \\
(0.0155)\end{array}$ \\
\hline $5 B \ldots$ & (2) & $\begin{array}{l}\text { AREX (even) } \\
\text { s.d. }\end{array}$ & $\begin{array}{l}=+0.723 \\
=(0.083)\end{array}$ & & & & $\begin{array}{r}-0.0174 \\
(0.0111)\end{array}$ \\
\hline - & (1) & $\begin{array}{l}\text { AREX } \\
\text { s.d. }\end{array}$ & $\begin{array}{l}=+0.895 \\
=(0.038)\end{array}$ & & & & \\
\hline $7 \ldots$ & (1) & $\begin{array}{l}\text { AREX } \\
\text { s.d. }\end{array}$ & $\begin{array}{l}=+0.860 \\
=(0.046)\end{array}$ & & & $\begin{array}{c}-0.0054 \\
(0.0028)\end{array}$ & \\
\hline
\end{tabular}

1158 cements; Avg $=0.7077$; S.D. $=0.0942 . \quad 279$ cements.

* Coef./s.d. ratio less than 1 .

** Coef./s.d. ratio less than 1 in equations for "odds" and "evens". 
centage expansion divided by the percentage shrinkage, for concretes having a nominal $51 / 2$ to various independent variables $(A R E X=A E X P / A S H R$ )

for 8 weeks and then placed in water for 4 weeks.

\begin{tabular}{|c|c|c|c|c|c|c|c|c|c|c|c|}
\hline $\mathrm{Na}_{2} \mathrm{O}$ & $\mathrm{MgO}$ & WAGN & $\mathrm{Li}$ & $\mathrm{SrO}$ & $\mathrm{Mn}$ & $\mathrm{Rb}$ & $\mathrm{Zn}$ & $\mathrm{Ba}$ & $\mathrm{W} / \mathrm{C}$ & ASHR & S.D. \\
\hline & & & & & & & & & $\begin{array}{c}*-0.0412 \\
(0.2970)\end{array}$ & & 0.0955 \\
\hline $\begin{array}{c}+0.0974 \\
(0.0418)\end{array}$ & $\begin{array}{c}+0.0174 \\
(0.0058)\end{array}$ & $\begin{array}{c}-0.000092 \\
(0.000032)\end{array}$ & & & & & & & & & 0.0885 \\
\hline $\begin{array}{c}+0.0946 \\
(0.0461)\end{array}$ & $\begin{array}{c}+0.0163 \\
(0.0059)\end{array}$ & $\begin{array}{c}-0.000061 \\
(0.000031)\end{array}$ & $\begin{array}{c}+6.20 \\
(2.16)\end{array}$ & $\begin{array}{c}-0.262 \\
(0.088)\end{array}$ & $\begin{array}{l}+0.088 \\
(0.055)\end{array}$ & $\begin{array}{r}+7.55 \\
(3.55)\end{array}$ & $\begin{array}{r}+0.315 \\
(0.214)\end{array}$ & $\begin{array}{c}+0.260 \\
(0.208)\end{array}$ & & & 0.0827 \\
\hline $\begin{array}{r}+0.1020 \\
(0.0692)\end{array}$ & $\begin{array}{c}+0.0156 \\
(0.0082)\end{array}$ & $\begin{array}{r}* 0.000033 \\
(0.000044)\end{array}$ & $\begin{array}{c}+6.89 \\
(3.12)\end{array}$ & $\begin{array}{c}-0.246 \\
(0.122)\end{array}$ & $\begin{array}{c}+0.201 \\
(0.077)\end{array}$ & $+\underset{(4.17)}{10.37}$ & $\begin{array}{c}+0.492 \\
(0.273)\end{array}$ & $\begin{array}{c}+0.486 \\
(0.308)\end{array}$ & & & 0.0798 \\
\hline $\begin{array}{c}+0.0982 \\
(0.0670)\end{array}$ & $\begin{array}{r}+0.0150 \\
(0.0098)\end{array}$ & $\begin{array}{c}-0.000084 \\
(0.000047)\end{array}$ & $\begin{array}{r}+5.45 \\
(3.19)\end{array}$ & $\begin{array}{c}-0.237 \\
(0.138)\end{array}$ & $\begin{array}{r}*+0.008 \\
(0.085)\end{array}$ & $\begin{array}{r}+7.28 \\
(5.94)\end{array}$ & $\begin{array}{c}*+0.063 \\
(0.384)\end{array}$ & $\begin{array}{r}*+0.162 \\
\quad(0.327)\end{array}$ & & & 0.0878 \\
\hline $\begin{array}{c}+0.0765 \\
(0.0425)\end{array}$ & $\begin{array}{c}+0.0148 \\
(0.0060)\end{array}$ & $\begin{array}{c}-0.000047 \\
(0.000029)\end{array}$ & & & 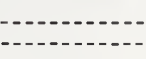 & & & & & & 0.0914 \\
\hline $\begin{array}{r}+0.0844 \\
(0.0459)\end{array}$ & $\begin{array}{r}+0.0158 \\
(0.0059)\end{array}$ & $\begin{array}{c}-0.000038 \\
(0.000028)\end{array}$ & $\begin{array}{r}+6.44 \\
(2.14)\end{array}$ & $\begin{array}{c}-0.290 \\
(0.079)\end{array}$ & $\begin{array}{r}+0.075 \\
(0.055)\end{array}$ & $\begin{array}{r}+6.76 \\
(3.52)\end{array}$ & $\begin{array}{c}+0.305 \\
(0.211)\end{array}$ & $\begin{array}{r}+0.295 \\
(0.200)\end{array}$ & & & 0.0829 \\
\hline $\begin{array}{r}+0.0805 \\
(0.0682)\end{array}$ & $\begin{array}{r}+0.0162 \\
(0.0082)\end{array}$ & $\begin{array}{r}* 0.000010 \\
(0.000042)\end{array}$ & $\begin{array}{c}+7.83 \\
(3.02)\end{array}$ & $\begin{array}{c}-0.301 \\
(0.117)\end{array}$ & $\begin{array}{c}+0.175 \\
(0.075)\end{array}$ & $\begin{array}{r}+9.07 \\
(4.64)\end{array}$ & $\begin{array}{c}+0.527 \\
(0.273)\end{array}$ & $\begin{array}{r}+0.547 \\
(0.306)\end{array}$ & & & 0.0801 \\
\hline $\begin{array}{c}+0.0817 \\
(0.0646)\end{array}$ & $\begin{array}{r}+0.0113 \\
(0.0093)\end{array}$ & $\begin{array}{c}-0.000054 \\
(0.000039)\end{array}$ & $\begin{array}{c}+5.87 \\
(3.16)\end{array}$ & $\begin{array}{c}-0.255 \\
(0.112)\end{array}$ & $\begin{array}{r}*-0.011 \\
(0.083)\end{array}$ & $\begin{array}{c}+6.30 \\
(5.86)\end{array}$ & $\begin{array}{r}*-0.044 \\
(0.361)\end{array}$ & $\begin{array}{r}*+0.099 \\
\quad(0.281)\end{array}$ & & & 0.0876 \\
\hline & & & & & & & & & & $\begin{array}{c}-6.500 \\
(1.183)\end{array}$ & 0.0869 \\
\hline $\begin{array}{r}* *+0.0711 \\
(0.0429)\end{array}$ & $\begin{array}{r}+0.0146 \\
(0.0055)\end{array}$ & & $\begin{array}{r}+5.16 \\
(2.03)\end{array}$ & $\begin{array}{c}-0.206 \\
(0.077)\end{array}$ & $\begin{array}{c}* *+\underset{(0.052)}{0.090} \\
(0.052\end{array}$ & $\begin{array}{r}+7.42 \\
(3.23)\end{array}$ & & & & $\begin{array}{c}-5.213 \\
(1.162)\end{array}$ & 0.0792 \\
\hline
\end{tabular}

expansion divided by the percentage shrinkage, for concretes having a nominal $51 / 2$ bags of ious independent variables $(A R E X=A E X P / A S H R)$

for 8 weeks and then placed in water for 4 weeks.

\begin{tabular}{|c|c|c|c|c|c|c|c|c|c|c|c|}
\hline $\mathrm{Na}_{2} \mathrm{O}$ & $\mathrm{MgO}$ & $W \Lambda G N$ & $\mathrm{Li}$ & SrO & Mn & $\mathrm{Rb}$ & $\mathrm{Zn}$ & $\mathrm{Ba}$ & $\mathrm{W} / \mathrm{C}$ & ASHR & S.D. \\
\hline 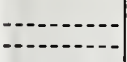 & & & & & & & & & $\begin{array}{c}-0.539 \\
(0.400)\end{array}$ & & 0.0952 \\
\hline $\begin{array}{c}+0.1082 \\
(0.0420)\end{array}$ & $\begin{array}{c}+0.0200 \\
(0.0059)\end{array}$ & $\begin{array}{c}-0.000093 \\
(0.000033)\end{array}$ & -...- & & & & & & & & 0.0874 \\
\hline $\begin{array}{r}+0.1023 \\
(0.0475)\end{array}$ & $\begin{array}{r}+0.0187 \\
(0.0061)\end{array}$ & $\begin{array}{c}-0.000068 \\
(0.000032)\end{array}$ & $\begin{array}{c}+5.18 \\
(2.20)\end{array}$ & $\begin{array}{r}-0.233 \\
(0.092)\end{array}$ & $\begin{array}{c}+0.094 \\
(0.057)\end{array}$ & $\begin{array}{c}+6.07 \\
(3.64)\end{array}$ & $\begin{array}{c}+0.312 \\
(0.215)\end{array}$ & $\begin{array}{c}+0.254 \\
(0.210)\end{array}$ & & & 0.0828 \\
\hline $\begin{array}{r}+0.1519 \\
(0.0814)\end{array}$ & $\begin{array}{r}*+0.0083 \\
(0.0103)\end{array}$ & $\begin{array}{c}-0.000110 \\
(0.000053)\end{array}$ & $\begin{array}{r}+5.05 \\
(3.21)\end{array}$ & $\begin{array}{r}-0.342 \\
(0.143)\end{array}$ & $+\begin{array}{c}0.155 \\
(0.079)\end{array}$ & $\begin{array}{c}+6.65 \\
(5.38)\end{array}$ & $\begin{array}{r}*+0.075 \\
(0.440)\end{array}$ & $\begin{array}{r}*+0.313 \\
(0.365)\end{array}$ & & & 0.0918 \\
\hline $\begin{array}{r}+0.0732 \\
(0.0627)\end{array}$ & $\begin{array}{c}+0.0253 \\
(0.0083)\end{array}$ & $\begin{array}{r}* 0.000025 \\
(0.000041)\end{array}$ & $\begin{array}{c}+6.91 \\
(3.29)\end{array}$ & $\begin{array}{c}-0.145 \\
(0.125)\end{array}$ & $\begin{array}{c}*+0.020 \\
(0.095)\end{array}$ & $\begin{array}{r}+8.35 \\
(5.35)\end{array}$ & $\begin{array}{c}+0.416 \\
(0.242)\end{array}$ & $\begin{array}{r}+0.281 \\
(0.278)\end{array}$ & & & 0.0757 \\
\hline $\begin{array}{r}+0.0934 \\
(0.0424)\end{array}$ & $\begin{array}{c}+0.0177 \\
(0.0060)\end{array}$ & $\begin{array}{c}-0.000055 \\
(0.000030)\end{array}$ & & -1 & & & & & & & 0.0896 \\
\hline $\begin{array}{c}+0.0924 \\
(0.0470)\end{array}$ & $\begin{array}{r}+0.0182 \\
(0.0061)\end{array}$ & $\begin{array}{c}-0.000049 \\
(0.000029)\end{array}$ & $\begin{array}{c}+6.04 \\
(2.17)\end{array}$ & $\begin{array}{c}-0.258 \\
(0.084)\end{array}$ & $\begin{array}{r}+0.081 \\
(0.056)\end{array}$ & $\begin{array}{c}+5.29 \\
(3.60)\end{array}$ & $\begin{array}{c}+0.307 \\
(0.212)\end{array}$ & $\begin{array}{c}+0.285 \\
(0.201)\end{array}$ & & & 0.0829 \\
\hline $\begin{array}{c}+0.1347 \\
(0.0806)\end{array}$ & $*+\begin{array}{r}0.0084 \\
(0.0103)\end{array}$ & $\begin{array}{c}-0.000081 \\
(0.000050)\end{array}$ & $\begin{array}{r}+5.46 \\
(3.16)\end{array}$ & $\begin{array}{c}-0.394 \\
(0.136)\end{array}$ & $\begin{array}{c}+0.127 \\
(0.077)\end{array}$ & $\begin{array}{r}+5.33 \\
(5.30)\end{array}$ & $\begin{array}{r}*+0.105 \\
\quad(0.434)\end{array}$ & $\begin{array}{r}+0.408 \\
(0.360)\end{array}$ & & & 0.0921 \\
\hline $\begin{array}{r}+0.0616 \\
(0.0588)\end{array}$ & $\begin{array}{c}+0.0239 \\
(0.0079)\end{array}$ & $\begin{array}{c}*-0.000019 \\
(0.000035)\end{array}$ & $\begin{array}{c}+7.12 \\
(3.19)\end{array}$ & $\begin{array}{c}-0.131 \\
(0.108)\end{array}$ & $\begin{array}{r}*+0.018 \\
(0.094)\end{array}$ & $\begin{array}{r}+7.93 \\
(5.22)\end{array}$ & $\begin{array}{c}+0.393 \\
(0.233)\end{array}$ & $\begin{array}{r}*+0.228 \\
(0.241)\end{array}$ & & & -0.0748 \\
\hline & & & & & $-2-4$ & -1 & & & & $\begin{array}{c}-6.328 \\
(1.259)\end{array}$ & 0.0877 \\
\hline $\begin{array}{r}*+0.0778 \\
(0.0442)\end{array}$ & $+\begin{array}{c}+0.0158 \\
(0.0057)\end{array}$ & & $+\begin{array}{r}+5.05 \\
(2.06)\end{array}$ & $\begin{array}{r}* *-0.181 \\
(0.087)\end{array}$ & 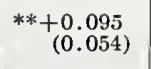 & $\begin{array}{r}+6.85 \\
(3.32)\end{array}$ & & & & $\begin{array}{c}-5.143 \\
(1.220)\end{array}$ & 0.0796 \\
\hline
\end{tabular}


TABLE 10-34. Calculated contributions to the ratio, percentage expansion after 28 days in water divided by the percentage shrinkage after 56 days in laboratory air, for concretes having a nominal $51 / 2$ bags of cement per cubic yard and a slump of $5 \pm 1$ in., and the calculated ranges of such contributions $(A R E X=A E X P / A S H R)$

\begin{tabular}{|c|c|c|c|c|}
\hline $\begin{array}{l}\text { Inde- } \\
\text { pendent } \\
\text { variables }\end{array}$ & $\begin{array}{l}\text { Range of } \\
\text { variables } \\
\text { (percent) }\end{array}$ & $\begin{array}{l}\text { Coefficients } \\
\text { from eq (3) } \\
\text { table 10-33 }\end{array}$ & $\begin{array}{l}\text { Calculated contri- } \\
\text { butions to AREX }\end{array}$ & $\begin{array}{l}\text { Calculat- } \\
\text { ed ranges } \\
\text { of contri } \\
\text { butions } \\
\text { to } \\
\text { AREX }\end{array}$ \\
\hline 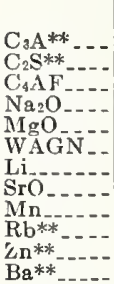 & $\begin{array}{c}0 \text { to } 15 \\
5 \text { to } 50 \\
4 \text { to } 17 \\
0 \text { to } 0.75 \\
0 \text { to } 5.0 \\
* 1300 \text { to } 2900 \\
0 \text { to } 0.02 \\
0 \text { to } 0.4 \\
0 \text { to } 1.0 \\
0 \text { to } 0.01 \\
0 \text { to } 0.2 \\
0 \text { to } 0.2\end{array}$ & $\begin{array}{l}-0.0042 \\
-0.00154 \\
-0.0090 \\
+0.1023 \\
+0.0187 \\
+0.000068 \\
+5.18 \\
-0.233 \\
+0.094 \\
+6.07 \\
+0.312 \\
+0.254\end{array}$ & $\begin{array}{r}\text { Const. }=+0.928 \\
0 \text { to }-0.063 \\
-0.008 \text { to }-0.077 \\
-0.036 \text { to }-0.153 \\
0 \text { to }+0.077 \\
0 \text { to }+0.094 \\
-0.088 \text { to }-0.197 \\
0 \text { to }+0.104 \\
0 \text { to }-0.093 \\
0 \text { to }+0.094 \\
0 \text { to }+0.061 \\
0 \text { to }+0.062 \\
0 \text { to }+0.051\end{array}$ & $\begin{array}{l}0.063 \\
0.069 \\
0.117 \\
0.077 \\
0.094 \\
0.109 \\
0.104 \\
0.093 \\
0.094 \\
0.061 \\
0.062 \\
0.051\end{array}$ \\
\hline
\end{tabular}

**Coefficient of doubtful significance as coef./s.d. ratio was less than 2 .
A corresponding series of calculations for the Series A concretes made of NAE cements is presented in table 10-39. Increases in $\mathrm{SrO}$, and possibly $\mathrm{Fe}_{2} \mathrm{O}_{3}$ and fineness were associated with an increase in the ratio. Increases in $\mathrm{Na}_{2} \mathrm{O}$ and $\mathrm{Li}$ may possibly be associated with decreases in the ratio.

\subsection{Shrinkage of Tops and Bottoms of Con- crete Specimens as Cast}

All of the data presented in this section on shrinkages and expansions, their differences, and their ratios have been based on averages of the measurements of the tops and bottoms of the specimens as cast. The results of measurements on the top of the concrete specimens and the bottom as cast usually differed. The frequency distribution of these differences obtained on the concretes of constant water/ce-

TABLE 10-35 Frequency distribution of cements with respect to the ratio (OSHR-OEXP)/OSHR of concretes having a nominal $51 / 2$ bags of cement per cubic yard and a water-cement ratio of 0.635

\begin{tabular}{|c|c|c|c|c|c|c|c|c|c|c|c|c|c|c|c|}
\hline \multirow{3}{*}{ Type cement } & \multicolumn{14}{|c|}{ Ratio } & \multirow{3}{*}{ Total } \\
\hline & $\begin{array}{c}-0.10 \\
\text { to } \\
-0.05\end{array}$ & $\begin{array}{c}-0.05 \\
\text { to } \\
0\end{array}$ & $\begin{array}{c}0 \\
\text { to } \\
0.05\end{array}$ & $\begin{array}{c}0.05 \\
\text { to } \\
0.10\end{array}$ & $\begin{array}{c}0.10 \\
\text { to } \\
0.15\end{array}$ & $\begin{array}{c}0.15 \\
\text { to } \\
0.20\end{array}$ & $\begin{array}{c}0.20 \\
\text { to } \\
0.25\end{array}$ & $\begin{array}{c}0.25 \\
\text { to } \\
0.30\end{array}$ & $\begin{array}{c}0.30 \\
\text { to } \\
0.35\end{array}$ & $\begin{array}{c}0.35 \\
\text { to } \\
0.40\end{array}$ & $\begin{array}{c}0.40 \\
\text { to } \\
0.45\end{array}$ & $\begin{array}{c}0.45 \\
\text { to } \\
0.50\end{array}$ & $\begin{array}{c}0.50 \\
\text { to } \\
0.55\end{array}$ & $\begin{array}{l}0.55 \\
\text { and } \\
\text { over }\end{array}$ & \\
\hline & \multicolumn{14}{|c|}{ Number of cements } & \\
\hline & 1 & 0 & 1 & 1 & 1 & 6 & 14 & 14 & 19 & 15 & 5 & 2 & & 3 & 82 \\
\hline & -- & $\cdots+-1$ & 1 & 2 & 4 & 5 & 3 & 11 & 18 & 14 & 9 & (n) & 1 & 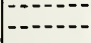 & 68 \\
\hline IIA & ---- & (n- & (-no & 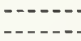 & & $-\overline{2}$ & 3 & 4 & $\begin{array}{l}1 \\
4\end{array}$ & $\frac{1}{6}$ & $-\overline{1}$ & 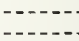 & 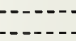 & (-n- & 20 \\
\hline III, V V & 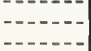 & 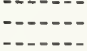 & \begin{tabular}{ll}
$-1-1-1$ \\
\hdashline$-n-1$
\end{tabular} & & 1 & & & & $\begin{array}{l}1 \\
3\end{array}$ & $\begin{array}{l}1 \\
5\end{array}$ & $-\overline{2}-$ & & & & $\begin{array}{r}3 \\
15\end{array}$ \\
\hline Total & 1 & 0 & 2 & 3 & 6 & 14 & 24 & 32 & 46 & 45 & 19 & 2 & 1 & 3 & 198 \\
\hline
\end{tabular}



bags of cement per cubic yard and a slump of $5 \pm 1 \mathrm{in}$.

\begin{tabular}{|c|c|c|c|c|c|c|c|c|c|c|c|c|c|}
\hline \multirow{3}{*}{ Type cement } & \multicolumn{12}{|c|}{ Ratio } & \multirow{3}{*}{ Total } \\
\hline & $\begin{array}{c}0 \\
\text { to } \\
0.05\end{array}$ & $\begin{array}{c}0.05 \\
\text { to } \\
0.10\end{array}$ & $\begin{array}{c}0.10 \\
\text { to } \\
0.15\end{array}$ & $\begin{array}{c}0.15 \\
\text { to } \\
0.20\end{array}$ & $\begin{array}{c}0.20 \\
\text { to } \\
0.25\end{array}$ & $\begin{array}{c}0.25 \\
\text { to } \\
0.30\end{array}$ & $\begin{array}{c}0.30 \\
\text { to } \\
0.35\end{array}$ & $\begin{array}{c}0.35 \\
\text { to } \\
0.40\end{array}$ & $\begin{array}{c}0.40 \\
\text { to } \\
0.45\end{array}$ & $\begin{array}{c}0.45 \\
\text { to } \\
0.50\end{array}$ & $\begin{array}{c}0.50 \\
\text { to } \\
0.55\end{array}$ & $\begin{array}{c}0.55 \\
\text { to } \\
0.60\end{array}$ & \\
\hline & \multicolumn{12}{|c|}{ Number of cements } & \\
\hline $\begin{array}{l}\text { II } \\
\text { IA } \\
\text { II } \\
\text { IIA }\end{array}$ & \begin{tabular}{c}
1 \\
-1 \\
\hdashline-1 \\
\hdashline-1
\end{tabular} & \begin{tabular}{l}
3 \\
$-\overline{5}$ \\
\hdashline-1 \\
\hdashline$-1-$ \\
\hdashline$-1-$
\end{tabular} & $\begin{array}{l}4 \\
-2 \\
-1 \\
1\end{array}$ & 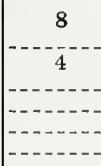 & \begin{tabular}{l}
7 \\
1 \\
7 \\
1 \\
3 \\
\hdashline 2
\end{tabular} & $\begin{array}{r}19 \\
1 \\
12 \\
1 \\
2 \\
1 \\
3\end{array}$ & $\begin{array}{r}16 \\
1 \\
20 \\
-10 \\
1 \\
1\end{array}$ & $\begin{array}{r}10 \\
2 \\
9 \\
- \\
3 \\
1 \\
4\end{array}$ & $\begin{array}{c}5 \\
1 \\
5 \\
-1\end{array}$ & \begin{tabular}{r}
2 \\
2 \\
2 \\
\hdashline$-1-$ \\
\hdashline$-1--$ \\
---1
\end{tabular} & 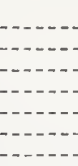 & $\begin{array}{c}3 \\
\\
\\
\end{array}$ & $\begin{array}{r}78 \\
8 \\
66 \\
2 \\
20 \\
3 \\
15\end{array}$ \\
\hline Total & 1 & 8 & 8 & 12 & 21 & 39 & 53 & 29 & 12 & 6 & 0 & 3 & 192 \\
\hline
\end{tabular}

ment ratio are presented in table 10-40. Although there were 12 instances where the bottom of the specimen had greater shrinkage than the top, the tops of the majority of the specimens had greater shrinkage than the bottoms. The equations presented in table 10-41 indicate that this difference was associated with higher average shrinkage (OSHR), as indicated in eqs 1 and 5 (see also table 10-44). The reduction in variance resulting from the use of the additional independent variables in eqs 4 or 8 was significant at the 5 -percent probability levels. The use of only commonly determined variables in eq 2 , or those with trace elements in eq 3 , resulted in a reduction in the S.D. value significant at the 5-percent probability level. In eqs 6 and 7 , the reduction in the S.D. was not significant at the 5-percent level (see table 10-44). Of the different independent variables in tables $10-41$, only OSHR, the average shrinkage of the top and bottom as cast, had a coef./s.d. ratio greater than 3 .

The frequency distribution of the differences of the shrinkage of tops and bottoms of the specimens as cast of the Series A concrete specimens is presented in table 10-42.

Equations are presented in table 10-43 indicating the relationship of the various independent variables to the difference in the shrinkage of the tops and bottoms of the Series A concrete specimens. The use of commonly determined variables in eqs $1,3,5$, and 7 resulted in a significant reduction in the S.D. values (see also table 10-44). The additional use of the trace elements, $\mathrm{Cr}, \mathrm{Rb}, \mathrm{Li}$, and $\mathrm{Ni}$ in eqs 2,4 , 6 , and 8 respectively, each resulted in a reduction in variance significant at the 1-percent probability level (see table 10-44).

A similar series of equations (not presented in tables) was calculated using the percentage 
TABLE 10-37. Coefficients for equations relating the (shrinkage-expansion)/shrinkage ratios ables; the 6-x 8-by 16-in. concrete specimens were cured in moist air for 14 days, then

\begin{tabular}{|c|c|c|c|c|c|c|}
\hline Equation & $\begin{array}{c}\text { Type } \\
\text { cement }\end{array}$ & Note & & Const. & $\mathrm{Na}_{2} \mathrm{O}$ & $\mathrm{MgO}$ \\
\hline 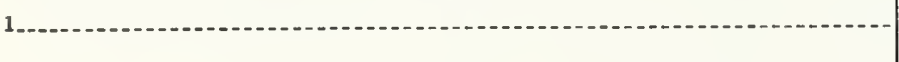 & $\mathrm{AE}+\mathrm{NAE}$ & (1) & $\begin{array}{l}\text { OEXR } \\
\text { s.d. }\end{array}$ & $\begin{array}{l}=+0.3398 \\
=(0.0610)\end{array}$ & $\begin{array}{r}-0.1664 \\
(0.0491)\end{array}$ & $\begin{array}{r}*-0.0083 \\
(0.0060)\end{array}$ \\
\hline 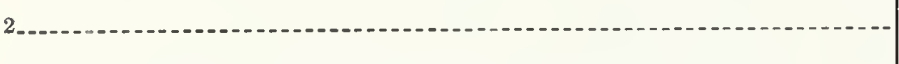 & NAE & $(2)$ & $\begin{array}{l}\text { OEXR } \\
\text { s.d. }\end{array}$ & $\begin{array}{l}=+0.3584 \\
=(0.0654)\end{array}$ & $\begin{array}{r}-0.1757 \\
(0.0518)\end{array}$ & $\begin{array}{r}*-0.0088 \\
(0.0063)\end{array}$ \\
\hline 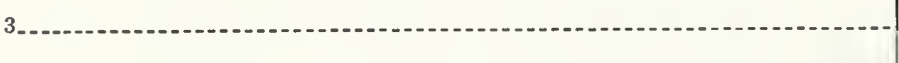 & $\mathrm{AE}+\mathrm{NAE}$ & $\left({ }^{3}\right)$ & $\begin{array}{l}\text { AEXR } \\
\text { s.d. }\end{array}$ & $\begin{array}{l}=+0.1939 \\
=(0.0630)\end{array}$ & $\begin{array}{r}*-0.0808 \\
(0.0455)\end{array}$ & $\begin{array}{r}-0.0157 \\
(0.0057)\end{array}$ \\
\hline 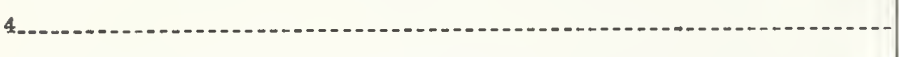 & NAE & (4) & $\begin{array}{l}\text { AEXR } \\
\text { s.d. }\end{array}$ & $\begin{array}{l}=+0.1723 \\
=(0.0652)\end{array}$ & $\begin{array}{r}-0.0939 \\
(0.0465)\end{array}$ & $\begin{array}{r}*-0.0181 \\
(0.0059)\end{array}$ \\
\hline
\end{tabular}

1178 cements; Avg $=0.3091 ;$ S.D. $=0.1037$.

2166 cements; Avg $=0.3063 ;$ S.D. $=0.1054$.

172 cements; Avg $=0.2957$; S.D. $=0.0937$.

160 cements; Avg $=0.2926 ;$ S.D. $=0.0937$.

"Coef./s.d. ratio was less than 1 in equations for "odds" and "evens".

TABLE 10-38. Calculated contributions to the OEXR ratio or $(O S H R-O E X P) / O S H R$, of concretes of nominal $51 / 2$ bags of cement per cubic yard and a water-cement ratio of 0.635 , and the calculated ranges of such contributions

\begin{tabular}{|c|c|c|c|c|}
\hline $\begin{array}{l}\text { Inde- } \\
\text { pendent } \\
\text { variables }\end{array}$ & $\begin{array}{l}\text { Range of } \\
\text { variables } \\
\text { (percent) }\end{array}$ & $\begin{array}{l}\text { Coeficients } \\
\text { from eq (2) } \\
\text { table 10-37 }\end{array}$ & $\begin{array}{l}\text { Calculated contrí- } \\
\text { butions to OEXR }\end{array}$ & $\begin{array}{c}\text { Calculat- } \\
\text { ed ranges } \\
\text { of contr- } \\
\text { butions } \\
\text { to } \\
\text { OEXR }\end{array}$ \\
\hline 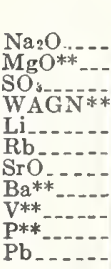 & $\begin{aligned} & 0 \text { to } 0.75 \\
& 0 \text { to } 5.0 \\
& 1.2 \text { to } 3.0 \\
& * 1300 \text { to } 2900 \\
& 0 \text { to } 0.02 \\
& 0 \text { to } 0.01 \\
& 0 \text { to } 0.4 \\
& 0 \text { to } 0.2 \\
& 0 \text { to } 0.1 \\
& 0 \text { to } 0.5 \\
& 0 \text { to } 0.05\end{aligned}$ & $\begin{array}{l}-0.1757 \\
-0.0088 \\
-0.0523 \\
+0.000049 \\
-5.042 \\
-8.542 \\
+0.4648 \\
-0.2521 \\
-0.7135 \\
-0.1011 \\
+2.741\end{array}$ & $\begin{array}{r}\text { Const. }=+0.3584 \\
0 \text { to }-0.132 \\
0 \text { to }-0.044 \\
-0.063 \text { to }-0.157 \\
+0.064 \text { to }+0.142 \\
0 \text { to }-0.101 \\
0 \text { to }-0.085 \\
0 \text { to }+0.196 \\
0 \text { to }-0.050 \\
0 \text { to }-0.071 \\
0 \text { to }-0.050 \\
0 \text { to }+0.137\end{array}$ & $\begin{array}{l}0.132 \\
0.044 \\
0.094 \\
0.078 \\
0.101 \\
0.085 \\
0.186 \\
0.050 \\
0.071 \\
0.050 \\
0.137\end{array}$ \\
\hline
\end{tabular}

$* \mathrm{~cm}^{2} / \mathrm{g}$.

**Coefficient of doubtful significance as coef./s.d. ratio was less than 2.
TABLE 10-39. Calculated contributions to the $A E X R$ ratio or $(A S H R-A E X P) / A S H R$ of concretes of nominal $51 / 2$ bags of cement per cubic yard and a slump of $\delta \pm 1$ in., and the calculated ranges of such contributions

\begin{tabular}{|c|c|c|c|c|}
\hline $\begin{array}{c}\text { Inde- } \\
\text { pendent } \\
\text { variables }\end{array}$ & $\begin{array}{l}\text { Range of } \\
\text { variables } \\
\text { (percent) }\end{array}$ & $\begin{array}{l}\text { Coefficients } \\
\text { from eq (4) } \\
\text { table 10-37 }\end{array}$ & $\begin{array}{l}\text { Calculated contri- } \\
\text { butions to AEXR }\end{array}$ & $\begin{array}{l}\text { Calculat- } \\
\text { ed ranges } \\
\text { of contri- } \\
\text { butions } \\
\text { to } \\
\text { AEXR }\end{array}$ \\
\hline 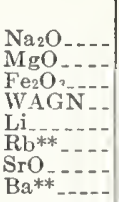 & $\begin{aligned} & 0 \text { to } 0.75 \\
& 0 \text { to } 5.0 \\
& 1.0 \text { to } 5.0 \\
& * 1300 \text { to } 2900 \\
& 0 \text { to } 0.02 \\
& 0 \text { to } 0.01 \\
& 0 \text { to } 0.4 \\
& 0 \text { to } 0.2\end{aligned}$ & $\begin{array}{l}-0.0939 \\
-0.0181 \\
+0.0184 \\
+0.000056 \\
-5.462 \\
-3.889 \\
+0.2834 \\
-0.2355\end{array}$ & $\begin{array}{r}\text { Conet. }=+0.1723 \\
0 \text { to }-0.070 \\
0 \text { to }-0.090 \\
+0.018 \text { to }+0.092 \\
+0.073 \text { to }+0.162 \\
0 \text { to }-0.109 \\
0 \text { to }-0.039 \\
0 \text { to }+0.113 \\
0 \text { to }-0.047\end{array}$ & $\begin{array}{l}0.070 \\
0.090 \\
0.074 \\
0.089 \\
0.109 \\
0.039 \\
0.113 \\
0.047\end{array}$ \\
\hline
\end{tabular}

TABLE 10-40. Frequency distribution of cements with respect to the difference of the percentage shrinkage of the top and bottom of specimens as cast of concretes having a nominal $5 \frac{1}{2}$ bags of cement per cubic yard and a water-cement ratio of 0.635 (ODSH)

\begin{tabular}{|c|c|c|c|c|c|c|c|c|c|c|c|c|c|}
\hline \multirow{3}{*}{ Type cement } & \multicolumn{12}{|c|}{ Difference in percentage shrinkage of top and bottom } & \multirow{3}{*}{ Total } \\
\hline & $\mid \begin{array}{c}-0.006 \\
\text { to } \\
-0.004\end{array}$ & $\left|\begin{array}{c}-0.004 \\
\text { to } \\
-0.002\end{array}\right|$ & $\mid \begin{array}{c}-0.002 \\
\text { to } \\
0.000\end{array}$ & $\begin{array}{c}0.000 \\
\text { to } \\
0.002\end{array}$ & $\begin{array}{c}0.002 \\
\text { to } \\
0.004\end{array}$ & $\begin{array}{c}0.004 \\
\text { to } \\
0.006\end{array}$ & $\begin{array}{c}0.006 \\
\text { to } \\
0.008\end{array}$ & $\begin{array}{l}0.008 \\
\text { to } \\
0.010\end{array}$ & $\begin{array}{c}0.010 \\
\text { to } \\
0.012\end{array}$ & $\begin{array}{c}0.012 \\
\text { to } \\
0.014\end{array}$ & $\begin{array}{c}0.014 \\
\text { to } \\
0.016\end{array}$ & $\begin{array}{c}0.016 \\
\text { to } \\
0.018\end{array}$ & \\
\hline & \multicolumn{12}{|c|}{ Number of cements } & \\
\hline & & 3 & 3 & 5 & 16 & 21 & 20 & 10 & 2 & --- & 1 & 1 & 82 \\
\hline II & 1 & $i^{-}$ & 2 & 11 & 15 & 20 & $\begin{array}{l}4 \\
7 \\
7\end{array}$ & $\begin{array}{l}1 \\
5\end{array}$ & $-\overline{2}$ & $2^{---}$ & 1 & (n) & $\begin{array}{r}8 \\
67\end{array}$ \\
\hline III & 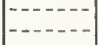 & - & 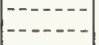 & & 3 & $-\overline{6}$ & $\frac{1}{4}$ & $\overline{2}$ & -- & -- & 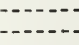 & 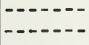 & 19 \\
\hline $\mathrm{IV}, \mathrm{v}$ & 1 & $\mid---1$ & 1 & $\overline{1}$ & $\frac{1}{4}$ & ${ }_{1}^{2}$ & $-\overline{2}$ & $\overline{1}$ & 2 & $\overline{1}$ & 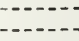 & 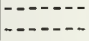 & 14 \\
\hline Total ... & 2 & 4 & 6 & 22 & 39 & 52 & 38 & 19 & 6 & 3 & 2 & 1 & 194 \\
\hline
\end{tabular}


of the concretes of nominal $51 / 2$ bags of cement per cubic yard to other independent varidried in laboratory air for 56 days, then placed in water for 28 days

\begin{tabular}{|c|c|c|c|c|c|c|c|c|c|c|c|}
\hline $\mathrm{SO}_{3}$ & $\underset{\text { content }}{\text { Air }}$ & $\mathrm{Fe}_{2} \mathrm{O}_{3}$ & WAGN & $\mathrm{Li}$ & $\mathrm{Rb}$ & $\mathrm{SrO}$ & Ba & V & $\mathbf{P}$ & $\mathrm{Pb}$ & S.D. \\
\hline $\begin{array}{r}-0.0515 \\
(0.0204\end{array}$ & $\begin{array}{r}* 0.0124 \\
(0.0100)\end{array}$ & & $\begin{array}{r}*+0.000049 \\
(0.000029)\end{array}$ & $\begin{array}{r}-5.750 \\
(2.432)\end{array}$ & $\begin{array}{r}-9.889 \\
(3.621)\end{array}$ & $\begin{array}{c}+0.4542 \\
(0.0867)\end{array}$ & $\begin{array}{r}*-0.2838 \\
(0.2261)\end{array}$ & $\begin{array}{r}*-0.7141 \\
(0.4479)\end{array}$ & $\begin{array}{r}*-0.1190 \\
(0.0638)\end{array}$ & $\begin{array}{r}*+2.698 \\
(1.142)\end{array}$ & 0.0874 \\
\hline \multirow[t]{3}{*}{$\begin{array}{c}-0.0523 \\
(0.0215)\end{array}$} & & & $\begin{array}{c}*+0.000049 \\
(0.000031)\end{array}$ & $\begin{array}{r}*-5.042 \\
(2.520)\end{array}$ & $\begin{array}{r}-8.542 \\
(3.804)\end{array}$ & $\begin{array}{r}+0.4648 \\
(0.0933)\end{array}$ & $\begin{array}{r}*-0.2521 \\
(0.2329)\end{array}$ & $\begin{array}{r}* 0.7135 \\
(0.4614)\end{array}$ & $\begin{array}{r}* 0.1011 \\
(0.0663)\end{array}$ & $*+\underset{(1.163)}{2.741}$ & 0.0880 \\
\hline & & $\begin{array}{r}*+0.0156 \\
(0.0088)\end{array}$ & $\begin{array}{r}+0.000045 \\
(0.000027)\end{array}$ & $\begin{array}{c}-5.857 \\
(2.112)\end{array}$ & $\begin{array}{c}-5.434 \\
(3.408)\end{array}$ & $\begin{array}{c}+0.3182 \\
(0.0778)\end{array}$ & $\begin{array}{r}*-0.2530 \\
(0.1968)\end{array}$ & & & & 0.0829 \\
\hline & & $\begin{array}{c}+0.0184 \\
(0.0088)\end{array}$ & $\begin{array}{c}*+0.000056 \\
(0.000028)\end{array}$ & $\begin{array}{c}-5.462 \\
(2.148)\end{array}$ & $\begin{array}{r}*-3.889 \\
(3.480)\end{array}$ & $\begin{array}{r}+0.2834 \\
(0.0827)\end{array}$ & $\begin{array}{r}*-0.2355 \\
(0.1984)\end{array}$ & & & & 0.0829 \\
\hline
\end{tabular}

shrinkage (ASHR) as an additional independent variable. A coef./s.d. ratio slightly greater than 3 was obtained for ASHR in an equation relating ADSH to ASHR.

\section{Discussion}

\subsection{Comparison of Equations for the Depend- ent Variables}

A summary of equations for shrinkage and expansion characteristics of the Series $O$ concretes using $\mathrm{AE}+\mathrm{NAE}$ cements is presented in table 10-45. The equations are presented vertically instead of horizontally as was also done in previous Sections. Also presented are the coef./s.d. ratios of each of the independent variables as well as the calculated ranges of the effects of these independent variables. It may be noted that in the first two equations (OSHR and OEXP), columns 1 and 2 , increases in $\mathrm{SO}_{3}$ and loss on ignition were associated with decreases in both shrinkage and expansion. Increased $\mathrm{Na}_{2} \mathrm{O}$ was associated with decreased shrinkage. Both the shrinkage and the expansion increased with increased $\mathrm{C}_{3} \mathrm{~A}, \mathrm{C}_{4} \mathrm{AF}$, fineness of the cement and the air content of the concrete.

It was previously indicated (tables 10-1 and 10-2) that concretes made with the air-entraining cements had lower cement content per unit volume than the others. There was, however, also probably a decrease in water content, and in fine and coarse aggregate per unit volume of concrete with an increase in air content. A decrease in the cement content may be expected to result in a decrease in the shrinkage [1]. L'Hermite [1] quoting Dutron [6] indicated that the shrinkage of concrete,

$$
\Delta_{b}=\gamma(e+c+v+f)^{n} \text { where } e=
$$

volume of water, $c=$ volume of cement, $v=$ volume of voids, and $f=$ volume of fines. It was not possible in our present series of tests to hold the cement content constant and vary only the air content. The void volume or air content appears to have a major effect when airentraining cements are included. Tables 10-5 and 10-9 indicated that for NAE cements, the air content had a coef./s.d. ratio less than 1 and was not a significant variable. The slump of the concretes made with AE cements was previously reported [3] as being high when a constant water/cement ratio was used. When the water content was adjusted to that required to produce the $5 \pm 1$-in-slump concretes, the air content still appeared to be associated with shrinkage, but not with expansion (see table 10-46).

The equations for the differences between the shrinkage on drying and the expansion on rewetting (i.e., the residual shrinkage) are presented in columns 3 and 4 of table 10-45. Column 3 indicates that increases in $\mathrm{C}_{4} \mathrm{AF}, \mathrm{C}_{3} \mathrm{~A} /$ $\mathrm{SO}_{3}$, fineness, and $\mathrm{SrO}$ were associated with increases in the residual-shrinkage values. Increases in Loss, $\mathrm{Rb}$, and possibly $\mathrm{Na}_{2} \mathrm{O}$, and $\mathrm{Li}$ were associated with decreases in these values in column 3 where the percentage shrinkage was not used as an independent variable. The greater the initial shrinkage, the greater the residual shrinkage, as indicated in column 4. Except for $\mathrm{Rb}$ and $\mathrm{SrO}$, none of the other independent variables had coef./s.d. ratios greater than 2 for the equation presented in column 4. 


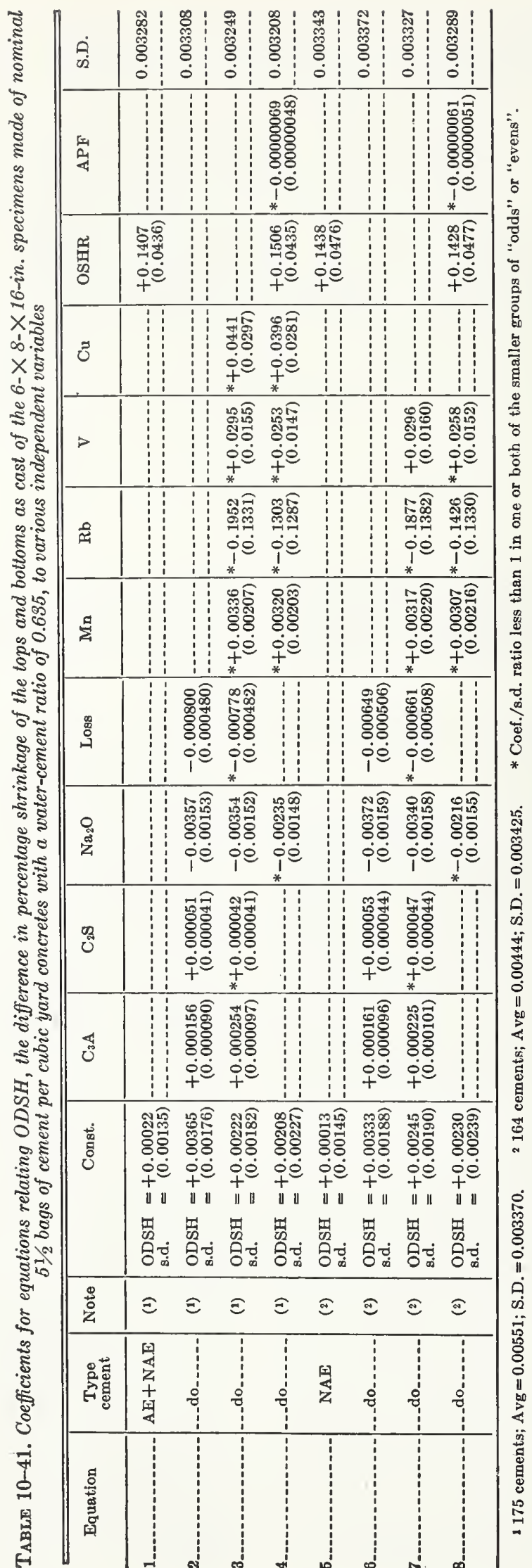


TABLE 10-42. Frequency distribution of cements with respect to the difference of the percentage shrinkage of the top and bottom of specimens as cast of concretes having a nominal $51 / 2$ bags of cement per cubic yard and a slump of $5 \pm 1$ in. (ADSH)

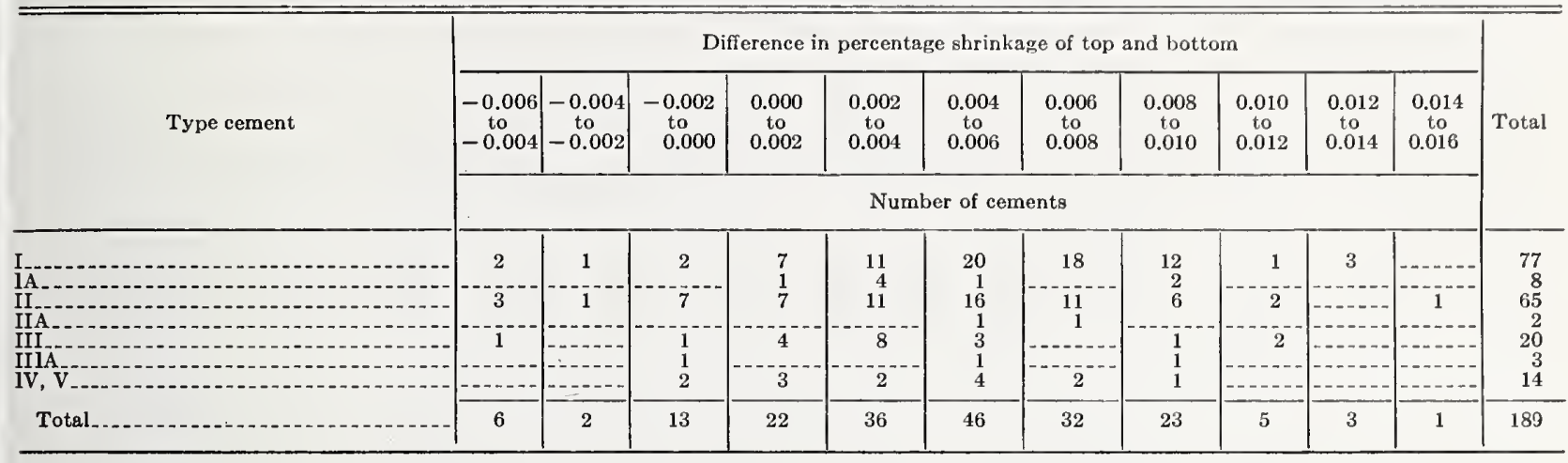

The equation for the ratio of the expansion divided by the shrinkage (OREX) (column 5) also indicates that the greater the shrinkage the smaller the expansion/shrinkage ratio. Increases in $\mathrm{Rb}$ and possibly $\mathrm{Na}_{2} \mathrm{O}, \mathrm{Li}$, and $\mathrm{C}_{3} \mathrm{~A}$ were associated with an increase in the ratio, and increases in $\mathrm{SrO}$ with decreases in the expansion/shrinkage ratios. Other independent variables had coefficients of doubtful significance as related to this ratio.

The equation in column 6 for the ratio of the difference between shrinkage and expansion divided by the shrinkage (OEXR) has only two independent variables, $\mathrm{Na}_{2} \mathrm{O}$ and $\mathrm{SrO}$, with coef./s.d. ratios greater than 3 . Increases in $\mathrm{SrO}$ and possibly $\mathrm{Pb}$ were associated with increases of the ratio. Increases in $\mathrm{Na}_{2} \mathrm{O}$ and possibly $\mathrm{Li}, \mathrm{Rb}$, and $\mathrm{SO}_{3}$ were associated with decreases of the ratio values.

A series of equations similar to those in table $10-45$ is presented in table $10-46$ for the Series A concretes made of $\mathrm{AE}+\mathrm{NAE}$ cements. In general, but with a few exceptions, the same independent variables had coef./s.d. ratios greater than one in equations in this table and in the previous table. The effect of the air content was previously noted and discussed.

\subsection{The Effect of Trace Elements}

Tables 10-45 and 10-46 show, as indicated in previous subsections where the equations were discussed, that the coef./s.d. ratios of the trace elements were generally less than 3 . This effect may have resulted from the fact that the concretes contained a lower percentage of the cements than did the mortars and neat pastes, and the influence of the trace elements is thereby more difficult to determine. It may also be that variations resulting from the use of different lots of sand and gravel in this study may have helped mask the effects of the independent variables used in the equations. Generally, the use of trace elements as independent variables in addition to commonly determined in- dependent variables in the multivariable equations resulted in a reduction in variance significant at the $a=0.01$ level although there were many instances where the reduction in variance was significant at the $a=0.05$ level.

\subsection{Agreement of Duplicate Determinations of Percentage Shrinkage and Percentage Expansion}

There were 26 pairs of duplicate spccimens where the water/cement ratio was the same for the Series $O$ and Series A concretes. The estimated standard deviation of individual measurements from the differences between these pairs was 0.0016 for the shrinkage values and 0.0015 for the expansion values.

A summary of the averages of shrinkage and expansion values obtained with the NAE cements is presented in table 10-47. Also presented are the S.D. values for the individual cements and the equations, and those calculated from duplicate determinations. The (S.D.) ${ }^{2}$ values for all the cements were from 5 to 12 times the (S.D.) ${ }^{2}$ values obtained from the duplicates.

It has been indicated in previous tables that, by use of various independent variables, a highly significant reduction in variance was obtained. The S.D. values of the "best" equations were, however, much greater than the S.D. values of the duplicate specimens. Each of these pairs of duplicate specimens was made the same day using a single lot of aggregates. Greater variations could be expected if the test specimens were made over a period of three years with different lots of aggregates and by different operators. This necessary procedure may also have affected the shrinkage and expansion values as measured and may have masked to some extent the effect of the independent variables, such as cement composition, on these properties. No control tests were carried on during the period the specimens of the 


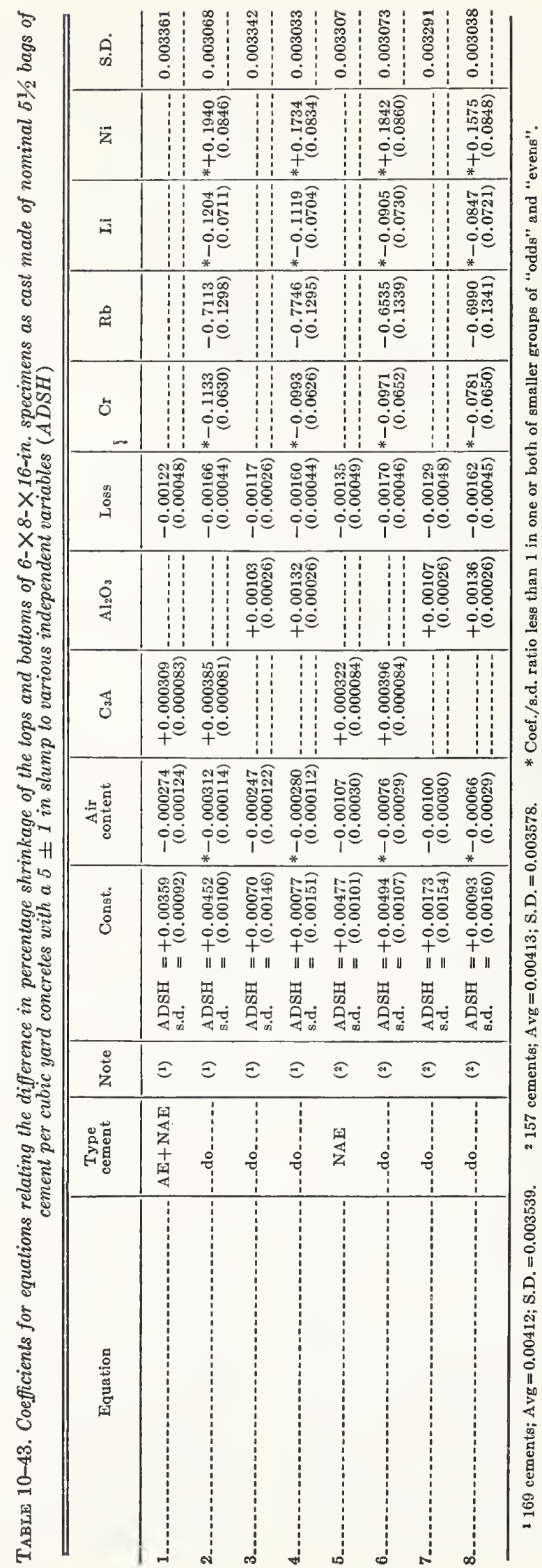


TABLE 10-44. "F" Values for significance of reduction of variance due to added variables

\begin{tabular}{|c|c|c|c|c|c|}
\hline \multirow{2}{*}{ Table } & \multirow{2}{*}{ Equations } & \multirow{2}{*}{$\begin{array}{l}\text { "F" } \\
\text { ratio }\end{array}$} & \multirow{2}{*}{ D.F. } & \multicolumn{2}{|c|}{ Critical " $F$ "' Ratio } \\
\hline & & & & $\alpha=0.01$ & $\alpha=0.05$ \\
\hline $10-4 \ldots$ & $\begin{array}{r}* 0,1 \\
0,2 \\
2,3 \\
0,4 \\
4,5\end{array}$ & $\begin{array}{r}6.20 \\
20.97 \\
3.92 \\
23.19 \\
3.71\end{array}$ & $\begin{array}{l}2: 175 \\
9: 168 \\
3: 165 \\
8: 169 \\
3: 166\end{array}$ & $\begin{array}{l}4.72 \\
2.51 \\
3.88 \\
2.61 \\
3.88\end{array}$ & $\begin{array}{l}3.05 \\
1.93 \\
2.67 \\
2.00 \\
2.67\end{array}$ \\
\hline $10-5 \ldots$ & $\begin{array}{r}* * 0,1 \\
0,2 \\
2,3 \\
0,4 \\
4,5\end{array}$ & $\begin{array}{r}5.07 \\
20.87 \\
3.76 \\
23.44 \\
3.51\end{array}$ & $\begin{array}{l}2: 163 \\
8: 157 \\
3: 154 \\
7: 158 \\
3: 155\end{array}$ & $\begin{array}{l}4.73 \\
2.62 \\
3.90 \\
2.75 \\
3.90\end{array}$ & $\begin{array}{l}3.05 \\
2.00 \\
2.67 \\
2.07 \\
2.67\end{array}$ \\
\hline $10-8 \ldots \ldots . .$. & $\begin{array}{r}*_{0}, 2 \\
0,3 \\
3,4 \\
0,5 \\
5,6\end{array}$ & $\begin{array}{r}4.69 \\
18.07 \\
3.65 \\
19.93 \\
3.68\end{array}$ & $\begin{array}{l}2: 169 \\
9: 162 \\
3: 159 \\
8: 163 \\
3: 160\end{array}$ & $\begin{array}{l}4.72 \\
2.52 \\
3.89 \\
2.62 \\
3.89\end{array}$ & $\begin{array}{l}3.05 \\
1.93 \\
2.67 \\
2.00 \\
2.67\end{array}$ \\
\hline $10-9 \ldots \ldots$ & $\begin{array}{r}* *_{0}, 1 \\
0,2 \\
0,3 \\
3,4 \\
0,5 \\
5,6\end{array}$ & $\begin{array}{r}2.72 \\
7.14 \\
19.04 \\
3.41 \\
21.28 \\
3.66\end{array}$ & $\begin{array}{l}2: 157 \\
2: 157 \\
8: 151 \\
3: 148 \\
7: 152 \\
3: 149\end{array}$ & $\begin{array}{l}4.74 \\
4.74 \\
2.63 \\
3.90 \\
2.76 \\
3.90\end{array}$ & $\begin{array}{l}3.05 \\
3.05 \\
2.00 \\
2.68 \\
2.07 \\
2.68\end{array}$ \\
\hline $10-12 \ldots \ldots$ & $\begin{array}{r}* 0,1 \\
0,2 \\
2,3 \\
0,4 \\
4,5\end{array}$ & $\begin{array}{r}3.20 \\
16.67 \\
3.77 \\
17.89 \\
3.62\end{array}$ & $\begin{array}{l}2: 174 \\
7: 169 \\
5: 164 \\
7: 169 \\
5: 164\end{array}$ & $\begin{array}{l}4.72 \\
2.74 \\
3.13 \\
2.74 \\
3.13\end{array}$ & $\begin{array}{l}3.05 \\
2.07 \\
2.27 \\
2.07 \\
2.27\end{array}$ \\
\hline $10-13 \ldots$ & $\begin{array}{r}* * 0,1 \\
0,2 \\
2,3 \\
0,4 \\
4,5\end{array}$ & $\begin{array}{r}1.51 \\
15.16 \\
4.73 \\
16.65 \\
4.48\end{array}$ & $\begin{array}{l}2: 162 \\
6: 158 \\
5: 153 \\
6: 158 \\
5: 153\end{array}$ & $\begin{array}{l}4.73 \\
2.93 \\
3.14 \\
2.93 \\
3.14\end{array}$ & $\begin{array}{l}3.05 \\
2.15 \\
2.27 \\
2.15 \\
2.27\end{array}$ \\
\hline $10-16$ & $\begin{array}{r}* 0,2 \\
0,3 \\
3,4 \\
4,5 \\
0,6 \\
6,7\end{array}$ & $\begin{array}{r}3.56 \\
6.17 \\
13.20 \\
3.66 \\
12.90 \\
3.52\end{array}$ & $\begin{array}{l}2: 169 \\
4: 167 \\
6: 161 \\
4: 157 \\
9: 162 \\
4: 158\end{array}$ & $\begin{array}{l}4.72 \\
3.42 \\
2.93 \\
3.43 \\
2.52 \\
3.43\end{array}$ & $\begin{array}{l}3.05 \\
2.43 \\
2.15 \\
2.43 \\
1.93 \\
2.43\end{array}$ \\
\hline $10-17 \ldots$ & $\begin{array}{r}* 0,2 \\
0,3 \\
3,4 \\
4,5 \\
0,6 \\
6,7\end{array}$ & $\begin{array}{r}3.60 \\
6.10 \\
15.23 \\
4.13 \\
14.27 \\
4.00\end{array}$ & $\begin{array}{l}2: 157 \\
4: 155 \\
5: 150 \\
4: 146 \\
8: 151 \\
4: 147\end{array}$ & $\begin{array}{l}4.74 \\
3.43 \\
3.14 \\
3.45 \\
2.63 \\
3.44\end{array}$ & $\begin{array}{l}3.05 \\
2.43 \\
2.27 \\
2.44 \\
2.00 \\
2.44\end{array}$ \\
\hline $10-20$ & $\begin{array}{r}* 0,1 \\
1,2 \\
0,3 \\
3,4\end{array}$ & $\begin{array}{r}7.74 \\
10.36 \\
117.05 \\
6.11\end{array}$ & $\begin{array}{l}7: 170 \\
3: 167 \\
2: 175 \\
6: 169\end{array}$ & $\begin{array}{l}2.74 \\
3.88 \\
4.72 \\
2.92\end{array}$ & $\begin{array}{l}2.07 \\
2.67 \\
3.05 \\
2.15\end{array}$ \\
\hline $10-21 \ldots$ & $\begin{array}{r}* * 0,1 \\
1,2 \\
0,3 \\
3,4\end{array}$ & $\begin{array}{r}7.87 \\
7.40 \\
67.95 \\
5.00\end{array}$ & $\begin{array}{l}7: 158 \\
3: 155 \\
3: 162 \\
7: 155\end{array}$ & $\begin{array}{l}2.75 \\
3.89 \\
3.89 \\
2.76\end{array}$ & $\begin{array}{l}2.07 \\
2.67 \\
2.67 \\
2.07\end{array}$ \\
\hline $10-24 \ldots$ & $\begin{array}{r}* 0,1 \\
1,2 \\
0,3 \\
3,4 \\
4,5\end{array}$ & $\begin{array}{r}7.01 \\
6.50 \\
95.03 \\
4.56 \\
4.79\end{array}$ & $\begin{array}{l}7: 164 \\
4: 160 \\
2: 169 \\
3: 166 \\
4: 162\end{array}$ & $\begin{array}{l}2.75 \\
3.43 \\
4.72 \\
3.88 \\
3.43\end{array}$ & $\begin{array}{l}2.07 \\
2.43 \\
3.05 \\
2.67 \\
2.43\end{array}$ \\
\hline $10-25 \ldots$ & $\begin{array}{r}* * 0,1 \\
1,2 \\
0,3 \\
3,4\end{array}$ & $\begin{array}{r}7.24 \\
4.15 \\
82.76 \\
4.15\end{array}$ & $\begin{array}{l}7: 152 \\
4: 148 \\
2: 157 \\
4: 153\end{array}$ & $\begin{array}{l}2.76 \\
3.44 \\
4.74 \\
3.44\end{array}$ & $\begin{array}{l}2.07 \\
2.44 \\
3.05 \\
2.44\end{array}$ \\
\hline $10-28 \ldots$ & $\begin{array}{r}* 0,1 \\
0,2 \\
1,3\end{array}$ & $\begin{array}{r}27.84 \\
7.77 \\
5.58\end{array}$ & $\begin{array}{l}2: 174 \\
8: 168 \\
7: 167\end{array}$ & $\begin{array}{l}4.71 \\
2.61 \\
2.74\end{array}$ & $\begin{array}{l}3.05 \\
2.00 \\
2.07\end{array}$ \\
\hline $10-29 \ldots$ & $\begin{array}{r}* * 0,1 \\
0,2 \\
1,3 \\
1,4\end{array}$ & $\begin{array}{r}25.76 \\
7.07 \\
5.31 \\
5.89\end{array}$ & $\begin{array}{l}2: 162 \\
8: 156 \\
7: 155 \\
7: 155\end{array}$ & $\begin{array}{l}4.73 \\
2.62 \\
2.75 \\
2.75\end{array}$ & $\begin{array}{l}3.05 \\
2.00 \\
2.07 \\
2.07\end{array}$ \\
\hline $10-32 \ldots$ & $\begin{array}{r}*_{0}, 2 \\
2,3 \\
0,4 \\
4,5 \\
0,6 \\
6,7\end{array}$ & $\begin{array}{r}4.17 \\
4.94 \\
3.04 \\
6.93 \\
15.67 \\
5.89\end{array}$ & $\begin{array}{l}7: 163 \\
6: 157 \\
5: 165 \\
6: 159 \\
2: 168 \\
7: 161\end{array}$ & $\begin{array}{l}2.75 \\
2.93 \\
3.13 \\
2.93 \\
4.73 \\
2.75\end{array}$ & $\begin{array}{l}2.07 \\
2.15 \\
2.07 \\
2.15 \\
3.05 \\
2.07\end{array}$ \\
\hline $10-33 \ldots$ & $\begin{array}{r}* * 0,2 \\
2,3 \\
0,4 \\
4,5 \\
0,6 \\
6,7\end{array}$ & $\begin{array}{r}4.65 \\
3.87 \\
4.33 \\
5.29 \\
13.14 \\
\mathbf{5 . 7 7}\end{array}$ & $\begin{array}{l}7: 151 \\
6: 145 \\
5: 153 \\
6: 147 \\
2: 156 \\
7: 149\end{array}$ & $\begin{array}{l}2.76 \\
2.93 \\
3.14 \\
2.93 \\
4.74 \\
2.76\end{array}$ & $\begin{array}{l}2.07 \\
2.15 \\
2.27 \\
2.15 \\
3.05 \\
2.07\end{array}$ \\
\hline
\end{tabular}

TABLE 10-44. "F" values for significance of reduction of variance due to added variables-Continued

\begin{tabular}{|c|c|c|c|c|c|}
\hline \multirow{2}{*}{ Table } & \multirow{2}{*}{ Equations } & \multirow{2}{*}{$\begin{array}{l}\text { "F" } \\
\text { rat1o }\end{array}$} & \multirow{2}{*}{ D.F. } & \multicolumn{2}{|c|}{ Critical " $F$ " Ratio } \\
\hline & & & & $\alpha=0.01$ & $\alpha=0.05$ \\
\hline $10-37 \ldots \ldots$ & $\begin{array}{r}* 0,1 \\
0,2 \\
0,3 \\
0,4\end{array}$ & $\begin{array}{l}6.58 \\
7.01 \\
6.30 \\
5.93\end{array}$ & $\begin{array}{c}13: 165 \\
12: 154 \\
9: 163 \\
9: 151\end{array}$ & $\begin{array}{l}2.31 \\
2.32 \\
2.52 \\
2.53\end{array}$ & $\begin{array}{l}1.80 \\
1.82 \\
1.93 \\
1.93\end{array}$ \\
\hline $10-41 \ldots \ldots$ & $\begin{array}{r}* 0,1 \\
0,2 \\
2,3 \\
1,4 \\
0,5 \\
0,6 \\
6,7 \\
5,8\end{array}$ & $\begin{array}{l}5.76 \\
2.32 \\
2.56 \\
2.34 \\
5.07 \\
2.04 \\
2.44 \\
2.07\end{array}$ & $\begin{array}{l}2: 173 \\
5: 170 \\
4: 166 \\
6: 167 \\
2: 162 \\
5: 159 \\
3: 156 \\
5: 157\end{array}$ & $\begin{array}{l}4.72 \\
3.12 \\
3.42 \\
2.92 \\
4.73 \\
3.13 \\
3.90 \\
3.13\end{array}$ & $\begin{array}{l}3.05 \\
2.27 \\
2.43 \\
2.15 \\
3.05 \\
2.27 \\
2.67 \\
2.27\end{array}$ \\
\hline $10-43 \ldots$ & $\begin{array}{r}* * 0,1 \\
1,2 \\
0,3 \\
3,4 \\
0,5 \\
5,6 \\
0,7 \\
7,9\end{array}$ & $\begin{array}{l}5.59 \\
9.26 \\
6.13 \\
9.83 \\
7.70 \\
7.05 \\
8.14 \\
7.63\end{array}$ & $\begin{array}{l}4: 165 \\
4: 161 \\
4: 165 \\
4: 161 \\
4: 153 \\
4: 149 \\
4: 153 \\
4: 149\end{array}$ & $\begin{array}{l}3.43 \\
3.43 \\
3.43 \\
3.43 \\
3.44 \\
3.44 \\
3.44 \\
3.44\end{array}$ & $\begin{array}{l}2.43 \\
2.43 \\
2.43 \\
2.43 \\
2.44 \\
2.44 \\
2.44 \\
2.44\end{array}$ \\
\hline
\end{tabular}

*Eauation 0 refers to the variance for the values themselves with no fitted equation for AE+ NAE cements (See footnote of Table). **As above, for NAE cements.

different concretes were made, so information on the possible effects of different lots of sand or of manipulative differences are not available.

\subsection{Shrinkage and Expansion of Concrete versus Shrinkage Characteristics of Neat Gement}

Equations were computed to find the relationship of each of the dependent variables for concrete of this section, i.e., OSHR, ASHR, OEXP, AEXP, ODSX, ADSX, OREX, AREX, OEXR, and AEXR, to the dependent variables for neat cement of the previous section, SH24, SH07, SH28, SH6M, SHBR, TOBR, SB/S7, and SB/ $\mathrm{S} 28$. The reduction in variance or " $\mathrm{F}$ " values were also calculated for each of the equations. There was an indication of a relationship between OEXP and AEXP values for the concretes and SH28 and SH6MI values for the neat cements significant at the 5-percent probability level. Neither the shrinkage values of the two series of concretes, the differences between the shrinkage and expansion, nor any of the various ratios showed an indication significant at the 5-percent level of a relationship with any of the shrinkage values obtained for the neat cements. This lack of relationship applied to both the nonrestrained shrinkage of the neat cements and the time of cracking of the annular rings.

There were, possibly, many factors which contributed to this lack of correlation. The neat cement pastes were made with a low water/ cement ratio; the concretes with a high water/ cement ratio. The neat cement pastes hydrated for only $24 \mathrm{hr}$ prior to drying; the concretes for 14 days. The specimens of neat cement had 
TABLE 10-45. Coefficients, coef./s.d. ratios and caiculated ranges of contributions of independent variables associated with shrinkage and expansion characteristics of concretes made with a water/cement ratio of 0.635

\begin{tabular}{|c|c|c|c|c|c|c|}
\hline Column & 1 & 2 & 3 & 4 & 5 & 6 \\
\hline Equation & 3 & 3 & 2 & 4 & 4 & 1 \\
\hline Table & $10-4$ & $10-12$ & $10-20$ & $10-20$ & $10-28$ & $10-37$ \\
\hline Dependent variable & OSHR & OEXP & ODSX & ODSX & OREX & OEXR \\
\hline & $=$ & $=$ & $=$ & $=$ & • & $=$ \\
\hline Constant & +0.0139 & +0.0107 & -0.00416 & -0.00466 & +0.8390 & +0.3398 \\
\hline $\begin{array}{l}\mathrm{C}_{3} \mathrm{~A}, \text { Coef } \\
\text { Coef./s.d. } \\
\text { Calculated range* }\end{array}$ & $\begin{array}{l}+0.00123 \\
8.8 \\
0.0185\end{array}$ & $\begin{array}{l}+0.000595 \\
\quad 6.0 \\
\quad 0.0089\end{array}$ & 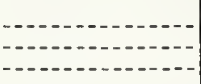 & 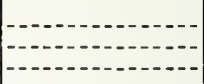 & $\begin{array}{l}+0.00498 \\
2.0 \\
0.0075\end{array}$ & - \\
\hline $\begin{array}{l}\mathrm{C}_{33} \mathrm{~S} \text {, coef } \\
\text { Coef./s.d } \\
\text { Calculated range. }\end{array}$ & $\begin{array}{l}* *-0.0000835 \\
1.6 \\
\quad 0.004\end{array}$ & 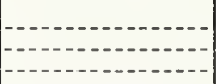 & $\begin{array}{l}---1 \\
---1 \\
---1\end{array}$ & 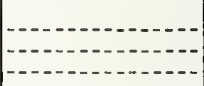 & -1 & - \\
\hline $\begin{array}{l}\text { CAAF, coef } \\
\text { Coef./s.d. } \\
\text { Calculated range }\end{array}$ & $\begin{array}{l}+0.000898 \\
\quad 5.3 \\
\quad 0.0117\end{array}$ & $\begin{array}{l}+0.000390 \\
3.4 \\
0.0051\end{array}$ & $\begin{array}{l}+0.000502 \\
\quad 3.6 \\
\quad 0.0065\end{array}$ & --------- & & \\
\hline $\begin{array}{l}\mathrm{Na}{ }_{2} \mathrm{O} \text {, coef } \\
\mathrm{Coef} \text {./s.d. } \\
\text { Calculated range. }\end{array}$ & $\begin{array}{l}-0.00822 \\
4.2 \\
0.0062\end{array}$ & 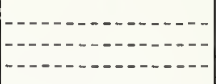 & $\begin{array}{l}-0.00485 \\
2.7 \\
0.0036\end{array}$ & $\begin{array}{l}* *-0.00231 \\
1.7 \\
0.0017\end{array}$ & $\begin{array}{l}+0.1273 \\
2.8 \\
0.0954\end{array}$ & $\begin{array}{l}-0.1664 \\
3.4 \\
0.1248\end{array}$ \\
\hline $\begin{array}{l}\mathrm{SO}_{3}, \text { coef } \\
\mathrm{Coef} . / \mathrm{s} . \mathrm{d} \\
\text { Calculated range. }\end{array}$ & $\begin{array}{l}-0.00894 \\
7.8 \\
0.0161\end{array}$ & $\begin{array}{l}-0.00411 \\
5.4 \\
0.0074\end{array}$ & 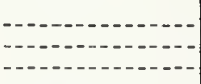 & 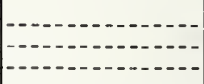 & 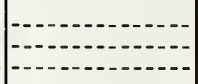 & $\begin{array}{l}-0.0515 \\
2.5 \\
0.0927\end{array}$ \\
\hline $\begin{array}{l}\mathrm{C}_{3} \mathrm{~A} / \mathrm{SO}_{3} \text {, coef } \\
\mathrm{Coef} \text {./s.d } \\
\text { Calculated range. }\end{array}$ & 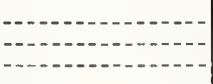 & 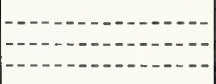 & $\begin{array}{l}+0.00097 \\
4.6 \\
\quad 0.0094\end{array}$ & $\begin{array}{l}* *-0.000164 \\
1.2 \\
0.0016\end{array}$ & 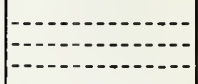 & 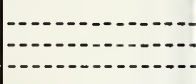 \\
\hline $\begin{array}{l}\mathrm{MgO} \text {, coef } \\
\mathrm{Coef} \text { //s.d } \\
\text { Calculated range- }\end{array}$ & 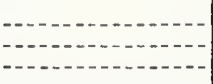 & 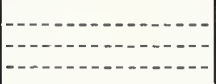 & 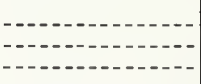 & $\begin{array}{c}* *-0.000231 \\
1.4 \\
0.0012\end{array}$ & $\begin{array}{l}* *+0.00871 \\
1.6 \\
0.0435\end{array}$ & $\begin{aligned} * *-0.0083 \\
1.3 \\
0.0415\end{aligned}$ \\
\hline $\begin{array}{l}\text { Loss, coef } \\
\text { Coef./s.d } \\
\text { Calculated range. }\end{array}$ & $\begin{array}{l}-0.00363 \\
5.6 \\
0.0109\end{array}$ & $\begin{array}{l}-0.0022 \\
5.0 \\
0.0066\end{array}$ & $\begin{array}{l}-0.00164 \\
3.1 \\
0.0049\end{array}$ & 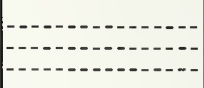 & 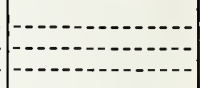 & 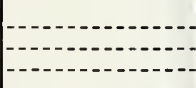 \\
\hline $\begin{array}{l}\text { APF, coef } \\
\text { Coef./s.d } \\
\text { Calculated range }\end{array}$ & $\begin{array}{l}+0.00000613 \\
7.9 \\
0.0180\end{array}$ & $\begin{array}{l}+0.0000030 \\
6.0 \\
\quad 0.0090\end{array}$ & $\begin{array}{l}+0.00000178 \\
\quad 3.1 \\
0.0053\end{array}$ & 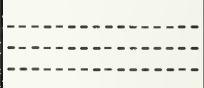 & 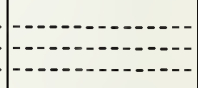 & 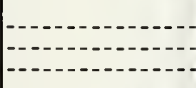 \\
\hline $\begin{array}{l}\text { Wagn., coef } \\
\text { Coef./s.d.-. } \\
\text { Calculated range.- }\end{array}$ & - & 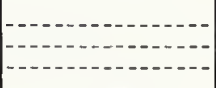 & 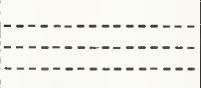 & 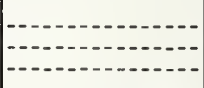 & 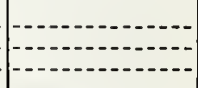 & $\begin{array}{rl}* *+ & 0.000049 \\
1 & .7 \\
& 0.0784\end{array}$ \\
\hline $\begin{array}{l}\text { Air content, coef } \\
\text { Coef./s.d. } \\
\text { Calculated range. }\end{array}$ & $\begin{array}{l}+0.00100 \\
\quad 5.6 \\
\quad 0.0100\end{array}$ & $\begin{array}{l}+0.000646 \\
5.5 \\
\quad 0.0065\end{array}$ & $\begin{array}{l}+0.000296 \\
2.0 \\
\quad 0.0030\end{array}$ & $\begin{aligned} * *- & 0.000158 \\
1.4 & \\
& 0.0016\end{aligned}$ & 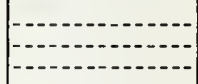 & $\begin{aligned} * *-0.0124 \\
1.2 \\
0.1240\end{aligned}$ \\
\hline $\begin{array}{l}\mathrm{Ba} \text {, coef } \\
\text { Coef./s.d } \\
\text { Calculated range. }\end{array}$ & 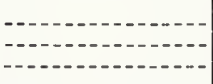 & 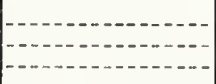 & |-1 & 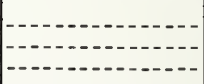 & $\begin{array}{rl}* & 0.2764 \\
1.4 \\
0.0553\end{array}$ & $\begin{array}{rl}* *-0 & 0.2838 \\
1.3 \\
0.0568\end{array}$ \\
\hline $\begin{array}{l}\text { Li, coef } \\
\text { Coef./s.d.d. } \\
\text { Calculated range. }\end{array}$ & 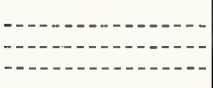 & 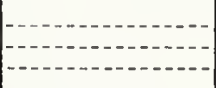 & $\begin{array}{l}-0.1923 \\
2.2 \\
0.0038\end{array}$ & $\begin{aligned} * *-0.0938 \\
1.4 \\
0.0019\end{aligned}$ & $\begin{array}{l}+4,353 \\
2.0 \\
0.0871\end{array}$ & $\begin{array}{l}-5.750 \\
2.4 \\
0.1150\end{array}$ \\
\hline $\begin{array}{l}\text { P, coef } \\
\text { Coef./s.d.d. } \\
\text { Calculated range }\end{array}$ & 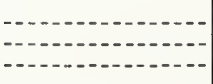 & $\begin{array}{rl}* * & 0.00369 \\
1.9 \\
0.0018\end{array}$ & 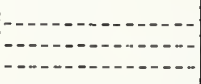 & 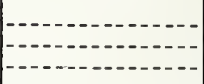 & -- & $\begin{aligned} * * & -0.1190 \\
1.9 & \\
& 0.0595\end{aligned}$ \\
\hline $\begin{array}{l}\mathrm{Pb} \text {, coef } \\
\text { Coef./s.d } \\
\text { Calculated range. }\end{array}$ & $-1-1-1$ & $\begin{array}{rl}* *-0 & .0518 \\
& 1.5 \\
& 0.0026\end{array}$ & 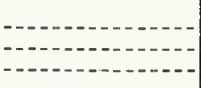 & - & & $\begin{array}{l}+2.698 \\
2.4 \\
\quad 0.1350\end{array}$ \\
\hline $\begin{array}{l}\text { Rb, coef } \\
\text { Coef./s.d. }\end{array}$ & 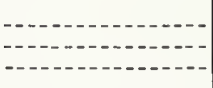 & $\begin{array}{l}+0.3234 \\
2.8 \\
0.0032\end{array}$ & $\begin{array}{l}-0.4920 \\
3.6 \\
0.0049\end{array}$ & $\begin{array}{l}-0.387 \\
3.8 \\
0.0039\end{array}$ & $\begin{array}{l}+11.29 \\
\quad 3.4 \\
\quad 0.1129\end{array}$ & $\begin{array}{l}-9.889 \\
2.7 \\
0.0989\end{array}$ \\
\hline $\begin{array}{l}\text { SrO, coef } \\
\text { Coef./s.d } \\
\text { Calculated range. }\end{array}$ & $\begin{array}{l}+0.00854 \\
2.1 \\
0.0034\end{array}$ & $\begin{aligned} * *-0.00378 \\
1.4 \\
0.0015\end{aligned}$ & $\begin{array}{l}+0.0114 \\
3.6 \\
\quad 0.0046\end{array}$ & $\begin{array}{l}+0.0082 \\
3.4 \\
\quad 0.0033\end{array}$ & $\begin{array}{l}-0.3005 \\
3.6 \\
0.1202\end{array}$ & $\begin{array}{l}+0.4542 \\
5.2 \\
0.1817\end{array}$ \\
\hline $\begin{array}{l}\text { V, coef } \\
\text { Coef./s.d.deulated range }\end{array}$ & --- & - & & & & $\begin{aligned} * *-0.7141 \\
1.6 \\
0.0714\end{aligned}$ \\
\hline $\begin{array}{l}\mathrm{Zn} \text {, coef } \\
\text { Coef./s.d } \\
\text { Calculated range. }\end{array}$ & $\begin{aligned}-0.0198 \\
2.0 \\
0.0040\end{aligned}$ & $\begin{aligned} * * & -0.0102 \\
& 1.6 \\
& 0.0020\end{aligned}$ & & & & \\
\hline $\begin{array}{l}\mathrm{Zr} \text {, coef } \\
\text { Coef./s,d } \\
\text { Calculated range }\end{array}$ & $\begin{array}{rl}* * & 0.0126 \\
1.6 \\
0.0063\end{array}$ & -- & & & & \\
\hline
\end{tabular}

See footnotes at end of table. 
TABLE 10-45. Coefficients, coef./s.d. ratios and calculated ranges of contributions of independent variables associated with shrinkage and expansion characteristics of concretes made with a water/cement ratio of 0.635 -Continued

\begin{tabular}{|c|c|c|c|c|c|c|}
\hline Column & 1 & 2 & 3 & 4 & 5 & 6 \\
\hline Equation & 3 & 3 & 2 & 4 & 4 & 1 \\
\hline Table & $10-4$ & $10-12$ & $10-20$ & $10-20$ & $10-28$ & $10-37$ \\
\hline Dependent variable & OSHR & OEXP & ODSX & ODSX & OREX & OEXR \\
\hline & $=$ & $=$ & $=$ & $=$ & $=$ & $=$ \\
\hline Constant & +0.0139 & +0.0107 & -0.00416 & -0.00466 & -0.8390 & +0.3398 \\
\hline $\begin{array}{l}\text { OSHR, coef } \\
\text { Coef./s.d-A } \\
\text { Calculated range. }\end{array}$ & & 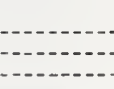 & 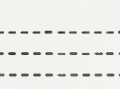 & $\begin{array}{c}+0.5223 \\
13.5 \\
0.0157\end{array}$ & $\begin{array}{l}-7.294 \\
6.0 \\
0.2188\end{array}$ & \\
\hline
\end{tabular}

* The calculated range was computed from the range of values for the cements times the coefficient for each independent variable. ** The independent variable is probably not significant as the coef./s.d. ratio is less than 2 .

TABLE 10-46. Coefficients, coef./s.d. ratios, and calculated ranges of contributions of independent variables associated with shrinkage and expansion characteristics of concretes having a slump of $5 \pm 1$ in.

\begin{tabular}{|c|c|c|c|c|c|c|}
\hline Column & 1 & 2 & 3 & 4 & 5 & 6 \\
\hline Equation & 4 & 5 & 2 & 5 & 7 & 3 \\
\hline Table & $10-8$ & $10-16$ & $10-24$ & $10-24$ & $10-32$ & $10-37$ \\
\hline \multirow[t]{2}{*}{ Dependent Variable } & ASHR & AEXP & $\operatorname{ADS} X$ & $\operatorname{ADSX}$ & AREX & AEXR \\
\hline & $=$ & $=$ & $=$ & $=$ & $=$ & $=$ \\
\hline Constant & +0.0129 & +0.0085 & -0.00519 & -0.00729 & +0.861 & +0.1939 \\
\hline $\begin{array}{l}\text { CaA, coef } \\
\text { Coef./s.d-d } \\
\text { Calculated range * }\end{array}$ & $\begin{array}{l}+0.001221 \\
8.4 \\
0.0183\end{array}$ & $\begin{array}{l}+0.000725 \\
\quad 6.6 \\
\quad 0.0108\end{array}$ & -- & & & \\
\hline $\begin{array}{l}\text { CaS coef } \\
\text { Coef./s.d-d } \\
\text { Calculated range. }\end{array}$ & $\begin{array}{l}-0.0000903 \\
\quad 1.7 \\
0.0004\end{array}$ & $\begin{array}{c}* *-0.000044 \\
1.1 \\
0.0002\end{array}$ & & & & \\
\hline $\begin{array}{l}\text { C4AF, coef } \\
\text { Coef./s.d-d } \\
\text { Calculated range- }\end{array}$ & $\begin{array}{l}+0.000918 \\
5.3 \\
\quad 0.0119\end{array}$ & $\begin{array}{l}+0.000344 \\
\quad 2.6 \\
\quad 0.0045\end{array}$ & $\begin{array}{l}+0.000552 \\
\quad 4.1 \\
\quad 0.0072\end{array}$ & $\begin{array}{l}+0.000175 \\
2.0 \\
\quad 0.0023\end{array}$ & $\begin{array}{c}* *-0.00467 \\
1.7 \\
0.0607\end{array}$ & 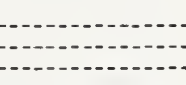 \\
\hline $\begin{array}{l}\mathrm{Fe}_{2} \mathrm{O}_{3}, \text { coef } \\
\text { Coef./8.d }-. . . . . . \\
\text { Calculated range. }\end{array}$ & 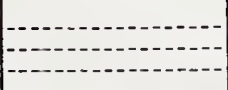 & 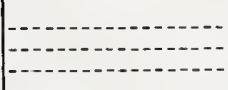 & $\begin{array}{l}-- \\
--\end{array}$ & & & $\begin{aligned} & * *+ 0.0156 \\
& 1.8 \\
& 0.0702\end{aligned}$ \\
\hline $\begin{array}{l}\mathrm{Na}_{2} \mathrm{O} \text {, coef } \\
\text { Coef./s.d. } \\
\text { Calculated range. }\end{array}$ & $\begin{array}{l}-0.00714 \\
\quad 3.6 \\
0.0054\end{array}$ & 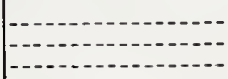 & $\begin{array}{l}+0.00402 \\
\quad 2.3 \\
\quad 0.0030\end{array}$ & $\begin{array}{ll}-- \\
--\end{array}$ & $\begin{array}{l}+0.0711 \\
\quad 1.7 \\
\quad 0.0533\end{array}$ & $\begin{aligned} * *-0.0808 \\
1.8 \\
0.0606\end{aligned}$ \\
\hline $\begin{array}{l}\mathrm{K}_{2} \mathrm{O} \text {, coef } \\
\text { Coef/s.d } \\
\text { Calculated range. }\end{array}$ & 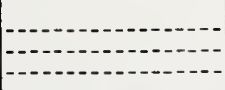 & $\begin{array}{l}+0.0026 \\
2.0 \\
0.0029\end{array}$ & 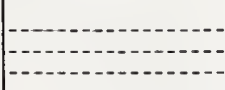 & & & \\
\hline $\begin{array}{l}\mathrm{SO}_{3} \text {, coef } \\
\text { Coef./s.d-d } \\
\text { Calculated range. }\end{array}$ & $\begin{array}{l}-0.00784 \\
6.7 \\
0.0141\end{array}$ & $\begin{array}{l}-0.00548 \\
\quad 6.1 \\
0.0099\end{array}$ & & $\begin{array}{c}* *+0.00080 \\
1.4 \\
0.0014\end{array}$ & & \\
\hline $\begin{array}{l}\mathrm{C} 2 \mathrm{~A} / \mathrm{SO}_{3}, \text { coef } \\
\mathrm{Coef} / \mathrm{s.d} \text {. } \\
\text { Calculated range. }\end{array}$ & 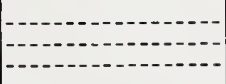 & (n) & $\begin{array}{l}+0.00080 \\
\quad 4.0 \\
\quad 0.0078\end{array}$ & & & 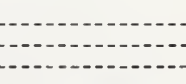 \\
\hline $\begin{array}{l}\mathrm{MgO} \text {, coef } \\
\text { Coef./s.d } \\
\text { Calculated range. }\end{array}$ & - n & $\begin{array}{c}* *+0.000428 \\
1.9 \\
0.0021\end{array}$ & 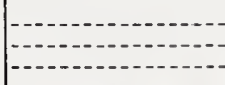 & $\begin{array}{l}-0.000370 \\
2.2 \\
0.0018\end{array}$ & $\begin{array}{l}-0.0146 \\
2.7 \\
0.0730\end{array}$ & $\begin{array}{l}-0.0157 \\
2.8 \\
0.0785\end{array}$ \\
\hline 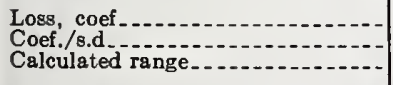 & $\begin{array}{l}-0.00381 \\
5.7 \\
0.0114\end{array}$ & $\begin{array}{l}-0.0025 \\
5.1 \\
0.0075\end{array}$ & $\begin{array}{l}-0.00165 \\
3.2 \\
0.0050\end{array}$ & & & $x^{-1}$ \\
\hline $\begin{array}{l}\text { APF, coef } \\
\text { Coef./s.d.d. } \\
\text { Calculated range. }\end{array}$ & $\begin{array}{l}+0.00000609 \\
7.7 \\
0.0183\end{array}$ & $\begin{array}{l}+0.00000431 \\
\quad 7.0 \\
\quad 0.0129\end{array}$ & $\begin{array}{l}+0.00000165 \\
2.9 \\
\quad 0.0049\end{array}$ & 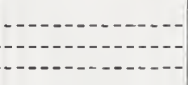 & & \\
\hline $\begin{array}{l}\text { Wagn, coef }-. . .- \\
\text { Coef./s.d. } \\
\text { Calculated range.- }\end{array}$ & - & - & - & $\ldots$ & - & $\begin{array}{rl}* *+ & 0.000045 \\
1.7 & 0.0720\end{array}$ \\
\hline
\end{tabular}


TABLE 10-46. Coefficients, coef. s.d.ratios, and calculated ranges of contributions of independent variables associated with shrinkage and expansion characteristics of concretes having a slump of $5 \pm 1$ in.-Continued

\begin{tabular}{|c|c|c|c|c|c|c|}
\hline Column & 1 & 2 & 3 & 4 & 5 & 6 \\
\hline Equation & 4 & 5 & 2 & 5 & 7 & 3 \\
\hline Table & $10-8$ & $10-16$ & $10-24$ & $10-24$ & $10-32$ & $10-37$ \\
\hline \multirow[t]{2}{*}{ Dependent Variable } & ASHR & AEXP & $\operatorname{ADSX}$ & $\operatorname{ADSX}$ & AREX & AEXR \\
\hline & $=$ & $=$ & $=$ & $=$ & $=$ & $=$ \\
\hline Constant & +0.0129 & +0.0085 & -0.00519 & -0.00729 & +0.861 & +0.1939 \\
\hline $\begin{array}{l}\text { Air content, coef } \\
\text { Coef..... } \\
\text { Calculated range-..-. }\end{array}$ & $\begin{array}{c}+0.000620 \\
4.1 \\
0.0062\end{array}$ & $\begin{array}{c}* *+0.000208 \\
1.8 \\
0.0021\end{array}$ & $\begin{array}{l}+0.000272 \\
2.2 \\
0.0027\end{array}$ & & & \begin{tabular}{l}
$-{ }^{\prime}$ \\
\hdashline$-{ }$
\end{tabular} \\
\hline 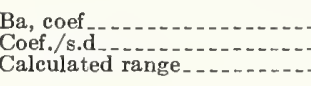 & & & & & & $\begin{array}{r}* *-0.2530 \\
1.3 \\
0.0506\end{array}$ \\
\hline $\begin{array}{l}\text { Li, coef } \\
\text { Coef./s.d. } \\
\text { Caleulated range.... }\end{array}$ & & & $\begin{array}{r}-0.1714 \\
2.1 \\
0.0034\end{array}$ & $\begin{array}{r}-0.1459 \\
2.5 \\
0.0029\end{array}$ & $\begin{array}{l}+5.16 \\
2.5 \\
0.1032\end{array}$ & $\begin{array}{l}-5.857 \\
2.87 \\
0.1171\end{array}$ \\
\hline $\begin{array}{l}\text { Mn, coef } \\
\text { Coef./s.d-_............... } \\
\text { Caleulated range-... }\end{array}$ &.- & $\begin{array}{l}+0.00418 \\
2.1 \\
0.0042\end{array}$ & $\begin{array}{c}* *-0.00274 \\
1.3 \\
0.0027\end{array}$ & $\begin{array}{c}* *-0.00305 \\
1.9 \\
0.0030\end{array}$ & $\begin{aligned} * *+0.090 \\
1.7 \\
0.0900\end{aligned}$ & \\
\hline 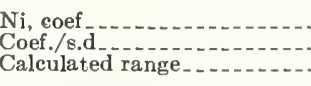 & & $\begin{aligned} * *+0.1149 \\
1.3 \\
0.0023\end{aligned}$ & 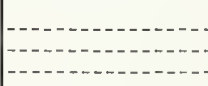 & & & \\
\hline 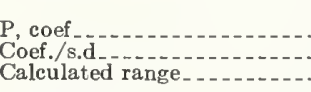 & & $\begin{array}{c}* *+0.00284 \\
\quad 1.3 \\
\quad 0.0014\end{array}$ & (1) & 2 & 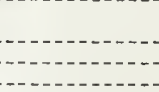 & $\mid--1+0,-$ \\
\hline $\begin{array}{l}\text { Rb, coef } \\
\text { Coef,/s,d.d. } \\
\text { Calculated range.... }\end{array}$ & & & $\begin{array}{l}-0.2812 \\
2.1 \\
0.0028\end{array}$ & $\begin{array}{l}-0.2592 \\
2.6 \\
0.0026\end{array}$ & $\begin{array}{l}+7.42 \\
2.3 \\
0.0742\end{array}$ & $\begin{aligned} * *-5.434 \\
1.6 \\
0.0543\end{aligned}$ \\
\hline $\begin{array}{l}\text { SrO, coef } \\
\text { Coef./s.d } \\
\text { Calculated range......... }\end{array}$ & $\begin{array}{c}+0.00828 \\
2.0 \\
\quad 0.0033\end{array}$ & (n) & $\begin{array}{l}+0.0108 \\
3.5 \\
\quad 0.0043\end{array}$ & $\begin{array}{c}+0.0047 \\
2.0 \\
0.0019\end{array}$ & $\begin{array}{l}-0.206 \\
2.7 \\
0.0824\end{array}$ & $\begin{array}{c}+0.3182 \\
4.1 \\
0.1273\end{array}$ \\
\hline 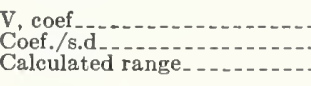 & 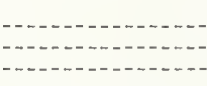 & $\begin{aligned} * * & +0.0237 \\
& 1.5 \\
& 0.0024\end{aligned}$ & & & & - \\
\hline $\begin{array}{l}\mathrm{Zn} \text {, coef } \\
\text { Coef,/s.d-d-d } \\
\text { Calculated range-- }\end{array}$ & $\begin{array}{r}-0.0216 \\
2.1 \\
0.0043\end{array}$ & & & & & \\
\hline $\begin{array}{l}Z_{\mathbf{r}}, \text { coef } \\
\text { Coef,/s, } \\
\text { Calculated range- }\end{array}$ & $\begin{array}{l}* *+0.00927 \\
\quad 1.1 \\
\quad 0.0046\end{array}$ & & & & & \\
\hline $\begin{array}{l}\text { ASHR, coef } \\
\text { Coef. s.d. } \\
\text { Calculated range- }\end{array}$ & & - & & $\begin{array}{r}+0.4705 \\
12.9 \\
0.0141\end{array}$ & $\begin{array}{l}-5.213 \\
4.5 \\
0.1564\end{array}$ & - \\
\hline
\end{tabular}

* The calculated range was computed from the range of values for the cements times the coefficient for each independent variable.

** The independent variable is probably not significant as the coef./s.d. ratio is less than 2 .

TABLE 10-47. Summary of averages and estimated standard deviations of concretes made of non-air-entraining cements

\begin{tabular}{l|c|c|c|c}
\hline \hline & $\begin{array}{c}\text { Averages, } \\
\text { cements } \\
\text { percent }\end{array}$ & $\begin{array}{c}\text { S.D. } \\
\text { cements }\end{array}$ & $\begin{array}{c}\text { S.D. } \\
\text { equations }\end{array}$ & $\begin{array}{c}\text { S.D. } \\
\text { duplicates }\end{array}$ \\
\hline OSHR & 0.0298 & 0.0056 & 0.0039 & 0.0016 \\
ASHR & 0.0056 & 0.0039 & 0.0016 \\
OEXP & 0.0296 & 0.0035 & 0.0027 & 0.0015 \\
AEXP & 0.0203 & 0.0038 & 0.0029 & 0.0015 \\
\hline
\end{tabular}

a 1-in-square cross-section; the concretes an approximate $6 \times 8$-in cross-section.

A comparison of table 9-35 of the previous section, indicating variables associated with shrinkage of neat cement, with tables 10-45 and 10-46 of this section, indicating summaries of the variables associated with the shrinkage and expansion of concretes, shows $\approx$ number of differences. An increase in fineness of the cements was possibly associated with an increase in shrinkage of the neat cements, but the coef./ s.d. for fineness was highly significant with the concretes. An increase in the $\mathrm{C}_{3} \mathrm{~A}$ was associated with a decrease of shrinkage of the neat cements and with an increase in shrinkage of the concretes. Increased $\mathrm{Na}_{2} \mathrm{O}, \mathrm{K}_{2} \mathrm{O}$ and possibly $\mathrm{Rb}$ were associated with increased shrinkage of the neat cements at 7 days and 28 days. For the concretes, an increase in $\mathrm{Na}_{2} \mathrm{O}$ was associated with a decrease in shrinkage, and $\mathrm{K}_{2} \mathrm{O}$ was apparently not associated with shrinkage. 


\subsection{Shrinkage and Expansion of Concretes versus the Dynamic Young's Modulus of Elasticity}

Equations were calculated to determine the relationship of the shrinkage, and expansion values of the concretes to the dynamic Young's modulus of elasticity of $3 \times 4 \times 16$-in specimens made of the same concretes, cured, and exposed to air, then soaked in water in the same manner as the $6 \times 8 \times 16$-in specimens. The results, as well as the reduction in variance or "F" values, are presented in table 10-48. The nomenclature used, OD14, OD42, OD70, and OD98, refers to the dynamic Young's modulus of elasticity in psi $\times 10^{-6}$ at 14 days (after moist-air curing), at 42 days (after 4 weeks air-drying), at 70 days (after 8 weeks drying in laboratory air), and at 98 days (after being in water for 4 weeks) respectively. The equations presented in this table are for the concretes made with a water/cement ratio of 0.635 . With the number of degrees of freedom involved, $2: 180$, "F" values of 4.70 and 3.05 must be equaled or exceeded for an indication of a relationship significant at the one or the 5 -percent probability levels, respectively.

The equations of table 10-48 indicate that an increase in the dynamic modulus of elasticity was associated with a decrease in the amount of shrinkage, with a decrease in the subsequent expansion when the concretes were rewetted, and with a decrease in the difference between

TABLE 10-48. Relationship of percentage shrinkage (OSHR), percentage expansion, $O E X P$, and percentage shrinkage minus percentage expansion of concrete $(O D S X)$ versus the dynamic modulus of elasticity of concrete specimens at various ages

\begin{tabular}{|c|c|c|c|c|c|}
\hline $\begin{array}{c}\text { Equa- } \\
\text { tion }\end{array}$ & & & & S.D. & $" F "$ \\
\hline 1. & $\begin{aligned} \text { OSHR } & =+0.0540 \\
\text { s.d. } & =(0.0054)\end{aligned}$ & $\begin{array}{c}-0.00497 \\
(0.00113)\end{array}$ & OD14 & 0.00552 & 9.7 \\
\hline 2. & $\begin{aligned} \text { OSHR } & =+0.0607 \\
\text { s.d. }= & (0.0051)\end{aligned}$ & $\begin{array}{r}-0.00661 \\
(0.00111)\end{array}$ & OD42 & 0.00531 & 17.7 \\
\hline 3 & $\begin{aligned} \mathrm{OSHR} & =+0.0619 \\
\text { s.d. } & =(0.0045)\end{aligned}$ & $\begin{array}{c}-0.00709 \\
(0.00100)\end{array}$ & OD70 & 0.00514 & 25.0 \\
\hline 4. & $\begin{aligned} \mathrm{OSHR} & =+0.0681 \\
\text { s.d. } & =(0.0070)\end{aligned}$ & $\begin{array}{c}-0.00743 \\
(0.00137)\end{array}$ & OD98 & 0.00539 & 14.7 \\
\hline 5. & $\begin{array}{r}\mathrm{OEXP}=+0.0315 \\
\text { s.d. }=(0.0037)\end{array}$ & $\begin{array}{c}-0.00225 \\
(0.00078)\end{array}$ & OD14 & 0.00381 & 4.2 \\
\hline 6. & $\begin{aligned} \text { OEXP } & =+0.0363 \\
\text { s.d. } & =(0.0036)\end{aligned}$ & $\begin{array}{c}-0.00337 \\
(0.00078)\end{array}$ & $\mathrm{OD} 42$ & 0.00371 & 9.4 \\
\hline 7 & $\begin{aligned} \mathrm{OEXP} & =+0.0366 \\
\text { s.d. } & =(0.0032)\end{aligned}$ & $\begin{array}{c}-0.00355 \\
(0.00071)\end{array}$ & OD70 & 0.00365 & 12.4 \\
\hline 8. & $\begin{array}{r}\mathrm{OEXP}=+0.0429 \\
\text { s.d. }=(0.0048)\end{array}$ & $\begin{array}{c}-0.00434 \\
(0.00094)\end{array}$ & OD98 & 0.00369 & 10.7 \\
\hline 19. & $\begin{aligned} \text { ODSX } & =+0.0224 \\
\text { s.d. } & =(0.0039)\end{aligned}$ & $\begin{array}{c}-0.00272 \\
(0.00082)\end{array}$ & OD14 & 0.00403 & 5.4 \\
\hline 10. & $\begin{aligned} \text { ODSX } & =+0.0244 \\
\text { s.d. } & =(0.0039)\end{aligned}$ & $\begin{array}{c}-0.00324 \\
(0.00083)\end{array}$ & OD42 & 0.00399 & 7.5 \\
\hline 11. & $\begin{array}{r}\text { ODSX }=+0.0393 \\
\text { s.d. }=(0.0034)\end{array}$ & $\begin{array}{c}-0.00354 \\
(0.00077)\end{array}$ & OD70 & 0.00393 & 10.7 \\
\hline 12. & $\begin{aligned} \mathrm{ODSX} & =+0.0252 \\
\text { s.d. } & =(0.0053)\end{aligned}$ & $\begin{array}{c}-0.00309 \\
(0.00103)\end{array}$ & OD98 & 0.00405 & 4.5 \\
\hline
\end{tabular}

the percentage shrinkage and percentage expansion, ODSX. The indication of relationship in eqs 5 and 12 were significant at the 5-percent level and in the others at the 1-percent level.

In table 9-36, Section 9, a series of equations was presented for the shrinkage of neat cement pastes versus the compressive strengths of 1:2.75 (cement to sand) mortars. Higher strength of the mortars at 1,3, and 7 days was associated with higher shrinkage of the neat cements at $24 \mathrm{hr}$ (after $24 \mathrm{hr}$ moist curing). There was no significant relationship between the shrinkage of the neat cements at later ages, up to 6 months, and the compressive strength of mortars at 1, 3, 7, or 28 days. An increase in the compressive strength of the mortars was associated with a decrease in the time of the annular specimens made of neat cement of normal consistency.

A series of equations was also calculated for the concretes made with sufficient water to give a $5 \pm 1$-in slump. These equations and the " $F "$ values, though not presented here, were very similar to the relationships presented in table 10-48 for constant water/cement ratio concretes.

It has been reported that shrinkage increases with an increase of the cement content of the concrete [1]. An increase in cement content would also result in a greater compressive strength and a higher dynamic modulus of elasticity. With any one cement there would be a greater amount of cement gel formed per unit volume in a given period of hydration if there was more cement to start with. The results of the present study indicate that greater shrinkage occurred with lower strength (lower dynamic E), and that concretes with higher strengths had lower shrinkages. The compounds and other independent variables associated with the shrinkage of concretes have been reported in this section; variables associated with dynamic Young's modulus of elasticity will be reported in a later section in this series.

\subsection{Top and Bottom Shrinkage and Ex- pansion}

The greater shrinkage of the tops of a majority of the specimens as cast is probably the result of settlement of the solids and normal bleeding. The actual water/cement ratio in the upper half of the 8-in depth of concrete at the time of setting may have been greater than in the bottom half, and such a difference could account for the greater shrinkage. It was noted that concretes with greater shrinkage of the top of the specimens when air dried usually had a greater expansion when the specimens were rewetted. Attempts were made (without success) to relate the difference in expansion of the tops and bottoms of specimens to various 
independent variables. The differences were usually slight, and the limitations of the measuring device, and the fact that in one case averages of two measurements and in the other case single measurements were used, may have masked any relationship.

\subsection{Comparative Test Values on other Hy- draulic Cements}

Tests were also made of concretes made of two portland-pozzolan cements and seven portland-blast-furnace-slag cements. All but one of the nine cements had shrinkage values in the " $O$ " series within the range of values of the concretes made of the portland cements. Concretes made of six of the nine cements had greater shrinkage and expansion values than the averages of the NAE portland cements. All the concretes were proportioned on a weight basis rather than a volume basis. The lower specific gravity of these cements resulted in a slightly greater volume of cementitious material in the concrete than would be the case with the portland cements.

\section{Summary and Conclusions}

(1) Two series of concretes were made with 199 portland cements having a broad range of composition and properties. In Series $O$ the water/cement ratio was 0.635 , and in Series $A$ the water/cement ratio was adjusted to give concretes with a $5 \pm 1$-in slump. Although designed for a cement content of 5.5 bags per cubic yard, the computed cement contents of concretes made of the air-entraining cements were considerably less than this value.

(2) Specimens, $6 \times 8 \times 16$ in, were made of the two series of concretes with each of the cements. Measurements were made of the shrinkage of the specimens when stored in laboratory air for 8 weeks after an initial 14day curing period. After the drying period, the specimens were stored in water for 4 weeks and measurements made of the expansion.

(3) Calculations were made of the difference between the percentage shrinkage and the percentage expansion, of the ratio of the expansion to initial shrinkage, and of the ratio of the difference to the initial shrinkage.

(4) The average shrinkage of the concrete specimens was 0.030 percent, with a range of about 0.015 to 0.045 percent. The estimated standard deviation of individual measurements obtained from duplicate specimens was 0.0016 .

(5) The average expansion of the air-dried concrete specimens when resoaked for 4 weeks was 0.020 percent, with a range of 0.011 to 0.035 percent. The estimated standard deviation of measurements on duplicate specimens was 0.0015 .

(6) The frequency distribution of the shrinkage and expansion for the concretes, as well as the residual shrinkage and ratios of shrinkage and expansion values of the concretes, indicated, in each instance, a fairly wide distribution of values. There was an overlapping of the shrinkage and expansion values obtained with the different types of cement as classified.

(7) Multivariable regression equations were used to determine which of the available independent variables or combinations of variables, such as cement composition, trace elements, fineness, and the air content of the concrete, were associated with the shrinkage and expansion characteristics. Typical equations are presented in table $10-45$ for the concretes made with a 0.635 water/cement ratio.

(7.1) Increases in $\mathrm{C}_{3} \mathrm{~A}, \mathrm{C}_{4} \mathrm{AF}$, fineness of the cement, and air content of the concrete were all associated with increases in both the shrinkage and the expansion values of the concretes.

(7.2) Increases in $\mathrm{Na}_{2} \mathrm{O}, \mathrm{SO}_{3}$, and loss on ignition of the cements were associated with decreases in the shrinkage values of the concretes. Increases in $\mathrm{SO}_{3}$ and loss on ignition were associated with decreases of the expansion values of the concretes.

(7.3) There was no highly significant indication of association of any of the individual trace elements of the cements with either the shrinkage or the expansion of the concrete. An increase in $\mathrm{Rb}$ may possibly be associated with an increase in expansion, an increase in $\mathrm{SrO}$ possibly with an increase in shrinkage, and an increase in $\mathrm{Zn}$ possibly with a decrease in shrinkage values. The trace elements of $\mathrm{P}, \mathrm{Pb}$, and $\mathrm{Zr}$ may possibly have an effect, but verification of their influence would require further investigation. The additional use of all the trace elements having a coef./s.d. ratio greater than 1 in the equations with the commonly determined variables usually resulted in a highly significant reduction of variance.

(7.4) The difference between the initial drying shrinkage and the subsequent expansion when the concrete specimens were rewetted (i.e. the residual shrinkage) was highly dependent on the values for the initial shrinkage. Equations calculated with only the cement composition and the air content as independent variables indicated that increases in $\mathrm{C}_{4} \mathrm{AF}$, $\mathrm{C}_{3} \mathrm{~A} / \mathrm{SO}_{3}$, fineness, $\mathrm{SrO}$, and possibly air content of the concrete were associated with increases in the residual-shrinkage values. Increases of loss on ignition, $\mathrm{Rb}$, and possibly $\mathrm{Na}_{2} \mathrm{O}$ and $\mathrm{Li}$ were associated with decreases in the residual-shrinkage values. When the initial 
shrinkage was included as an independent variable, only $\mathrm{Rb}$ and $\mathrm{SrO}$ were related to the residual shrinkage. Sodium oxide, $\mathrm{C}_{3} \mathrm{~A} / \mathrm{SO}_{3}$, $\mathrm{MgO}$, air content and Li had coef./s.d. ratios between one and two and were possibly not associated with residual shrinkage, but further study of their effects may be warranted.

(7.5) The ratio of expansion/shrinkage values was highly dependent on the initial shrinkage value. Increases in $\mathrm{Rb}$, and possibly $\mathrm{Na}_{2} \mathrm{O}$, $\mathrm{Li}$, and $\mathrm{C}_{3} \mathrm{~A}$ were associated with higher expansion/shrinkage ratios. Increases in $\mathrm{SrO}$ as well as the initial shrinkage were associated with decreases in the expansion/shrinkage ratio.

(7.6) The equations for the ratio of residual shrinkage divided by the shrinkage had only two independent variables that were highly significant. Increases in $\mathrm{SrO}$ and possibly $\mathrm{Pb}$ were associated with increases in the ratio. Increases in $\mathrm{Na}_{2} \mathrm{O}$ and possibly $\mathrm{SO}_{3}, \mathrm{Li}$ and $\mathrm{Rb}$ were probably associated with decreases in the ratio.

(7.7) Equations calculated for the shrinkage, expansion, differences, and expansion/ shrinkage ratios of specimens made of concretes having a $5 \pm 1$-in slump were in general agreement with those calculated for the 0.635 water/cement-ratio concretes. Some differences may be noted in comparing tables 10-45 and $10-46$.

(7.8) In equations calculated for the non-airentraining cements, the coef./s.d. ratio for air- content of the concretes was usually less than 1 and always less than 2.

(7.9) Equations calculated using the principal oxides instead of the potential compounds resulted in approximately the same estimated standard deviations and reduction-in-variance values.

(8) The shrinkage values of the two series of concrete specimens moist cured for 14 days and then air dried did not show, at the 5-percent probability level, a relationship to the shrinkage values of the neat cement bars of normal consistency, moist cured for $24 \mathrm{hr}$, and then air dried.

(9) The shrinkage and expansion values of the two series of concrete specimens did not show at the 5-percent level a relationship with time of cracking of the restrained annular specimens made of the neat cement, moist cured for $24 \mathrm{hr}$ and then air dried.

(10) Higher shrinkage values and higher expansion values of the concretes were associated with lower dynamic modulus of elasticity values of the concretes.

Acknowledgments are made to R. A. Clevenger who supervised the proportioning of the concrete, fabrication of the specimens, and making of measurements. Acknowledgments are also made to Elden Steward, A. C. Figlia, and other members of the staff for their able assistance in conducting the tests.

\section{References}

[1] L'Hermite, R. G. Volume changes of concrete, Proceedings of the Fourth International Symposium on the Chemistry of Cement, 1960, Washington, NBS Mono. 43, Vol 2, p. 659-702.

[2] Swayze, M. A. Discussion, (same as reference above), p. 700-702.

[3] Interrelations between Cement and Concrete Products, Part 1, NBS Building Science Series No. 2, Aug. 20, 1965 .

Section 1, Materials and techniques, by R. L. Blaine, H. T. Arni, and B. E. Foster.

Section 2, Water requirements of portland cement, by R. L. Blaine, H. T. Arni, and R. A. Clevenger.

Section 3, Occurrence of minor and trace elements in portland cement, by R. L. Blaine, Leonard Bean, and Elizabeth $\mathrm{K}$. Hubbard.

[4] Interrelations between Cement and Concrete Products, Part 2, NBS Building Science Series No. 5, July $1,1966$.
Section 4, Variables associated with expansion in the potential sulfate expansion test, by R. L. Blaine, H. T. Arni and D. N. Evans.

Section 5, Heat of hydration of portland cement, by R. L. Blaine and H. T. Arni.

Section 6, Variables associated with small autoclave expansion values of portland cements, by R. L. Blaire and H. T. Arni.

[5] Interrelations between Cement and Concrete Properties, Part 3, NBS Building Science Series No. 8, April 1968.

Section 7, Compressive Strength of Test Mortars, by R. L. Blaine, H. T. Arni, and M. R. DeFore.

Section 8, Compressive strength of steam-cured portland cement mortars, by $R$. L. Blaine, H. T. Arni, and M. R. DeFore.

[6] R. Dutron, Le retrait des ciments et betons, Ann. Trav. Publ. de Belgique (April-June 1934). 


\section{RELATED PUBLIGATIONS}

NBS Monograph 43-Chemistry of Cement Proceedings of the Fourth International Symposium-Washington 1960. Presented in two volumes. Volume I- $\$ 6.50$. Volume II-\$6.25. The two volumes at $\$ 12.75$ a set. (Originally issued September 1962, and reprinted February 1964.)

NBS Building Science Series 2, 5, and 8-Interrelations between Cement and Concrete Properties. Part 1-35 cents. Section 1, Materials and Techniques. Section 2, Water Requirements of Portland Cement. Section 3, Occurrence of Minor Trace Elements in Portland Cement. Part 2-35 cents. Section 4, Variables Associated with Expansion in the Potential Sulfate Expansion Test. Section 5, Heat of Hydration of Portland Cement. Section 6, Variables Associated with Small Autoclave Expansion Values of Portland Cements. Part 3-55 cents. Section 7, Compressive Strength of Portland Cement Test Mortars. Section 8, Compressive Strength of Steam-cured Portland Cement Mortars.

NBS Building Science Series 17-Causes of Variations in Chemical Analyses and Physical Tests of Portland Cement. (In press.)

* Order publications from Superintendent of Documents, Government Printing Office, Washington, D.C., 20402. (For foreign mailing, add onefourth of the price of the publication.) 


\section{ANNOUNCEMENT OF NEW PUBLICATIONS IN BUILDING SCIENCE SERIES}

Superintendent of Documents, Government Printing Office, Washington, D.C., 20402

Dear Sir :

Please add my name to the announcement list of new publications to be issued in the series: National Bureau of Standards Building Science Series.

Name

Company

Address

City

State

Zip Code

(Notification key $\mathrm{N}-339$ ) 



\section{PERIODICALS}

JOURNAL OF RESEARCH reports National Bureau of Standards research and development in physics, mathematics, chemistry, and engineering. Comprehensive scientific papers give complete details of the work, including laboratory data, experimental procedures, and theoretical and mathematical analyses. Illustrated with photographs, drawings, and charts.

Published in three sections, available separately:

\section{Physics and Chemistry}

Papers of interest primarily to scientists working in these fields. This section covers a broad range of physical and chemical research, with major emphasis on standards of physical measurement, fundamental constants, and properties of matter. Issued six times a year. Annual subscription: Domestic, $\$ 6.00$; foreign, $\$ 7.25^{*}$.

\section{Mathematical Sciences}

Studies and compilations designed mainly for the mathematician and theoretical physicist. Topics in mathematical statistics, theory of experiment design, numerical analysis, theoretical physics and chemistry, logical design and programming of computers and computer systems. Short numerical tables. Issued quarterly. Annual subscription: Domestic, $\$ 2.25$; foreign, $\$ 2.75 *$.

\section{Engineering and Instrumentation}

Reporting results of interest chiefly to the engineer and the applied scientist. This section includes many of the new developments in instrumentation resulting from the Bureau's work in physical measurement, data processing, and development of test methods. It will also cover some of the work in acoustics, applied mechanics, building research, and cryogenic engineering. Issued quarterly. Annual subscription: Domestic, $\$ 2.75$; foreign, $\$ 3.50 *$.

\section{TECHNIGAL NEWS BULLETIN}

The best single source of information concerning the Bureau's research, developmental, cooperative and publication activities, this monthly publication is designed for the industry-oriented individual whose daily work involves intimate contact with science and technology-for engineers, chemists, physicists, research managers, product-development managers, and company executives. Annual subscription: Domestic, $\$ 3.00$; foreign, $\$ 4.00^{*}$.

\section{NONPERIODICALS}

Applied Mathematics Series. tables, manuals, and studies.

Building Science Series. Research results, test methods, and performance criteria of building materials, components, systems, and structures.

Handbooks. Recommended codes of engineering and industrial practice (including safety codes) developed in cooperation with interested industries, professional organizations, and regulatory bodies.

Special Publications. Proceedings of NBS conferences, bibliographies, annual reports, wall charts, pamphlets, etc.

Monographs. Major contributions to the technical literature on various subjects related to the Bureau's scientific and technical activities.

National Standard Reference Data Series. NSRDS provides quantitative data on the physical and chemical properties of materials, compiled from the world's literature and critically evaluated.

Product Standards. Provide requirements for sizes, types, quality and methods for testing various industrial products. These standards are developed cooperatively with interested Government and industry groups and provide the basis for common understanding of product characteristics for both buyers and sellers. Their use is voluntary.

Technical Notes. This series consists of communications and reports (covering both other agency and NBS-sponsored work) of limited or transitory interest.

Federal Information Processing Standards Publications. This series is the official publication within the Federal Government for information on standards adopted and promulgated under the Public Law 89-306, and Bureau of the Budget Circular A-86 entitled, Standardization of Data Elements and Codes in Data Systems.

\section{CLEARINGHOUSE}

The Clearinghouse for Federal Scientific and Technical Information, operated by NBS, supplies unclassified information related to Governmentgenerated science and technology in defense, space, atomic energy, and other national programs. For further information on Clearinghouse services, write:

Clearinghouse

U.S. Department of Commerce Springfield, Virginia 22151 
U.S. DEPARTMENT OF COMMERCE

WASHINGTON, D.C. 20230

OFFICIAL BUSINESS 